\title{
NIST in the CFR:
}

\section{A Report on References to NIST (and NBS) Products and Services in the Code of Federal Regulations}

Ileana Martínez

Ajit Jillavenkatesa Carmiña Londoño 
NIST IR 7241

\section{NIST in the CFR:}

\section{A Report on References to NIST (and NBS) Products and Services in the Code of Federal Regulations}

Ileana Martínez

Ajit Jillavenkatesa Carmiña Londoño Global Standards and Information Group Standard Services Division Technology Services

July 2005

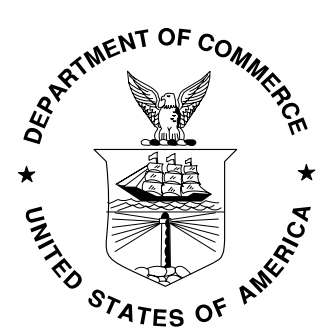

U.S. DEPARTMENT OF COMMERCE Carlos M. Gutierrez, Secretary TECHNOLOGY ADMINISTRATION Michelle O'Neill, Acting Under Secretary of Commerce for Technology NATIONAL INSTITUTE OF STANDARDS AND TECHNOLOGY 


\section{Table of Contents}

Table of Contents $\quad$ i

List of Tables $\quad$ ii

$\begin{array}{ll}\text { Appendices } & \text { ii }\end{array}$

Acronyms Used iii

Executive Summary $\quad$ iv

1. Objective 1

2. The Nation's Measurement System 1

3. The Code of Federal Regulations 2

4. The National Institute of Standards and Technology 2

5. NIST in CFR Studies and Data 3

5.1 Previous Studies 3

5.2 Data Used for this Study 3

6. Analyses of NIST in CFR References 6

6.1 Traceability and Calibration 6

6.2 Standard Reference Materials (SRMs) 8

6.3 Special Publications (SP) 11

6.4 Assorted Publications 11

6.5 Weights and Measures Handbooks

6.6 Accreditation, The National Voluntary Laboratory Accreditation Program (NVLAP) and the National Voluntary Conformity Assessment System Evaluation (NVCASE) 13

6.7 Voluntary Product Standards and Commercial Standards 14

6.8 Computer Security 14

$\begin{array}{lll}6.9 \text { Circular } 484 & 16\end{array}$

6.10 Handbook $69 \quad 16$

6.11 Handbook $28 \quad 16$

$\begin{array}{lll}6.12 & \text { Handbook 81 } & 16\end{array}$

6.13 National Technology Transfer and

$\begin{array}{lll}6.14 & \text { Handbook 91 } & 17\end{array}$

$\begin{array}{lll}6.15 & \text { Handbook } 96 & 17\end{array}$

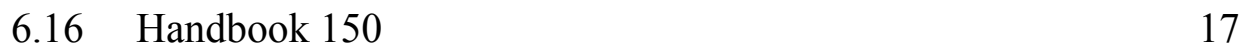


7. Availability of NIST products cited in the CFR 18

$\begin{array}{ll}\text { 8. Conclusions } & 18\end{array}$

$\begin{array}{ll}\text { 9. Recommendations } & 20\end{array}$

\section{List of Tables}

1. References to NIST/NBS Products and Services by CFR Title and Department/Agency

2. Distribution of Citations by Category 5

3. Availability of specifically identified SRMs $\quad 10$ 


\section{Appendices}

1. Listing of References to NIST and NBS in the Code of Federal Regulations (Martinez and DeVaux)

2. Federal Agencies Referencing NIST and NBS in the Code of Federal Regulations (Martinez and DeVaux)

3. Listing of References to NIST and NBS in the Code of Federal Regulations (Aanstoos)

4. References to NIST/NBS in the Code of Federal Regulations by title (Aanstoos)

5. References to NIST and NBS Traceability and Calibration in the Code of Federal Regulations

6. SRM References to NIST and NBS in the Code of Federal Regulations

7. References to NIST and NBS Special Publications in the Code of Federal Regulations

8. References to NIST and NBS Publications (assorted) in the Code of Federal Regulations

9. References to Weights and Measures Handbooks (Handbooks 44, 105-1 and 133 ) in the Code of Federal Regulations

10. References to Accreditation, National Voluntary Laboratory Accreditation Program (NVLAP) and the National Voluntary Conformity Assessment System Evaluation (NVCASE) in the Code of Federal Regulations

11. References to Voluntary Product Standards (VPS) and Commercial Standards (CS) in the Code of Federal Regulations

12. References to NIST and NBS Products on Computer Security in the Code of Federal Regulation

13. References to Circular 484 in the Code of Federal Regulations

14. References to Handbook 69 in the Code of Federal Regulations

15. References to Handbook 28 in the Code of Federal Regulations

16. References to Handbook 81 in the Code of Federal Regulations

17. References to the National Technology Transfer and Advancement Act (NTTAA) in the Code of Federal Regulations

18. References to Handbook 91 in the Code of Federal Regulations

19. References to Handbook 96 in the Code of Federal Regulations

20. References to Handbook 150 in the Code of Federal Regulations

21. References to Handbook 136 in the Code of Federal Regulations

22. Compiled list of NIST and NBS products and services in the Code of Federal Regulations (listed by CFR title)

23. Availability of NIST/NBS publications cited in the CFR 


\section{Acronyms Used}

\begin{tabular}{|l|l|}
\hline CFR & Code of Federal Regulations \\
\hline CPSC & Consumer Product Safety Commission \\
\hline DHS & Department of Homeland Security \\
\hline DoC & Department of Commerce \\
\hline DoD & Department of Defense \\
\hline DoE & Department of Energy \\
\hline DoL & Department of Labor \\
\hline DoT & Department of Transportation \\
\hline EPA & Environmental Protection Agency \\
\hline FAA & Federal Aviation Administration \\
\hline FCC & Federal Communication Commission \\
\hline FDA & Food and Drug Administration \\
\hline FERC & Federal Energy Regulatory Commission \\
\hline FMCSA & Federal Motor Carrier Safety Administration \\
\hline FSIS & Food Safety and Inspection Service \\
\hline FTC & Federal Trade Commission \\
\hline GIPSA & Grain Inspection, Packers and Stockyards Administration \\
\hline HHS & Department of Health and Human Services \\
\hline HUD & Housing and Urban Development \\
\hline MSHA & Mine Safety and Health Administration \\
\hline NBS & National Bureau of Standards \\
\hline NHTSA & National Highway Traffic Safety Administration \\
\hline NIST & National Institute of Standards and Technology \\
\hline NRC & Nuclear Regulatory Commission \\
\hline NVCASE & National Voluntary Conformity Assessment System Evaluation \\
\hline NVLAP & National Voluntary Laboratory Accreditation Program \\
\hline OPM & Office of Personnel Management \\
\hline OSHA & Occupational Safety and Health Administration \\
\hline RSPA & Research and Special Programs Administration \\
\hline USCG & United States Coast Guard \\
\hline USDA & Department of Agriculture \\
\hline WHD & Wage and Hourly Division \\
\hline & \\
\hline
\end{tabular}




\title{
NIST in the CFR: \\ A Report on References to NIST (and NBS) Products and Services in the CFR
}

\begin{abstract}
Executive Summary
Regulations promulgated by different federal government departments and agencies refer to various NIST (and NBS) products. These references can be found in the Code of Federal Regulations (CFR). This report examines the references to identify, categorize and analyze the various NIST/NBS products and services cited. Compiling this information, the report provides conclusions on the value of NIST products and services for regulatory purposes to other federal government agencies and, based on an analysis of the references, provides recommendations for follow-up actions.
\end{abstract}




\section{NIST in CFR: \\ A Report on \\ References to NIST (and NBS) Products and Services in the Code of Federal Regulations}

\section{Objective}

The purpose of this study is to: (1) identify and categorize explicit references to the National Institute of Standards and Technology (NIST) and its predecessor, the National Bureau of Standards (NBS), in the Code of Federal Regulations (CFR); (2) analyze the citations to NIST/NBS in order to highlight the value of NIST to the United States Government, industry and the public; and (3) help define NIST's role in the nation's measurement system (NMS).

A first step in identifying unmet measurement needs is to determine the NIST products and services that other federal agencies identify through regulations in the Code of Federal Regulations.

This study did not capture indirect CFR references to NIST/NBS products and services, such as any agency regulation that refers to a documentary standard developed by a standards development organization (SDO) which, in turn, refers to a NIST/NBS product such as a Standard Reference Material or calibration service. Similarly, administrative references to NIST, such as authorization to create programs, are not included in this report.

\section{The Nation's Measurement System}

The National Institute of Standards and Technology is presently evaluating its role in the nation's measurement system (NMS). NIST developed a White Paper for internal discussion which includes a working definition of the NMS as "the complex of all methods, instruments, entities, institutions, and standards that support measurements of products and processes of national significance to the economy, quality of life, or security of the nation, where measurement is the process of quantitatively comparing a variable characteristic, property, or attribute of a substance, object, or system to norm" 1 . The White Paper also lists a number of potential roles for NIST, concluding that NIST should take the lead in:

- Identifying unmet measurement needs of U.S. industry, commerce, regulatory agencies, and national defense

- Identifying needed de-facto national standards of measurement

- Initiating collaborations with and among government agencies and industrial institutions with unmet measurements needs and responding appropriately

\footnotetext{
${ }^{1}$ White Paper: Potential Roles for NIST in the Nation's Measurement System, NIST National Measurement System Task Group, June 11, 2004; https://www-i.nist.gov/director/WP_MeasSystems.htm
} 
- Developing or collaborating with others on developing measurements, methods and standards to fill identified national measurement needs

- Supporting other government agencies with special measurement needs

\section{The Code of Federal Regulations}

As a compilation of permanent rules and regulations adopted by all executive departments and agencies of the United States Government, the Code of Federal Regulations (CFR) is the single resource for finding the complete listing of U.S federal government rules and regulations, as well as their administrative scope. The CFR differs from the Federal Register in that the latter, published daily, officially announces proposed and final rules, notices issued by Federal agencies and organizations, as well as executive orders and other presidential documents.

The CFR is organized in 50 titles, subdivided into chapters, parts, subparts and sections. Each title represents a broad area subject to federal regulation. In general, each chapter in the CFR provides the rules and regulations issued by a given agency, and each part in the chapter contains information pertaining to a single regulatory program. All titles are updated yearly in order to keep CFR information current. Hard copies of the CFR, published by the National Archives and Records Administration (NARA), can be purchased from the Government Printing Office; an electronic version is available without charge on-line at http://www.gpoaccess.gov/cfr/index.html and at http://www.gpoaccess.gov/ecfr. Certain chapters or texts thereof may be available on one website and not on the other.

\section{National Institute of Standards and Technology}

The mission of the National Institute of Standards and Technology (NIST), a nonregulatory federal agency within the U.S. Commerce Department's Technology Administration, is to develop and promote measurement, standards, and technology to enhance productivity, facilitate trade, and improve the quality of life. Founded in 1901 as the National Bureau of Standards (NBS), its name was changed to the National Institute of Standards and Technology and its mission was expanded under provisions of the Omnibus Trade and Competitiveness Act of 1988. NIST is the national metrology institute (NMI) of the United States, with core activities in metrology, measurement science, measurement services, and support for documentary standards. NIST offers numerous measurement- and metrology-related products and services that are used, adopted and/or mandated by other U.S. Government agencies and industry. For example, federal agency mandates in the Code of Federal Regulations include : (a) the use of NIST Standard Reference Materials (SRM) for calibration of equipment used in testing; (b) that equipment be calibrated through calibration services offered by NIST; (c) traceability to national physical standards realized by NIST; (d) accreditation of testing laboratories by the National Voluntary Laboratory Accreditation Program (NVLAP), administered by NIST; and (e) the use of weights and measures handbooks developed by NIST. 


\section{NIST in CFR Studies and Data}

\subsection{Previous studies}

Two previous studies identified and compiled NIST/NBS references using two different approaches. In the first study, Martinez and DeVaux ${ }^{2}$, searched the CFR to identify references to NIST/NBS and identified them with the keywords listed in Appendix 1. Martinez and DeVaux concluded that approximately 30 agencies reference NIST and/or NBS products or services, with citations falling into 4 broad categories: (a) references to NIST Handbooks; (b) references to other NIST/NBS publications; (c) references to NIST/NVLAP accreditation; and (d) references to traceability/calibration to NIST standards and to SRMs. Those authors also identified erroneous practices and misuse of terminology, such as: (a) interchangeable and incorrect use of the terms 'traceability' and 'calibration'; (b) references to documents from the $1950 \mathrm{~s}, 60 \mathrm{~s}$ and $70 \mathrm{~s}$, that are no longer valid, not available, or perhaps withdrawn; (c) references to NBS instead of the correct current name, NIST, and some references to both NBS and NIST in the same paragraph. Martinez and DeVaux identified a total of 240 citations. Those references, organized by federal agency, are summarized in Appendix 2.

In the second study, Aanstoos ${ }^{3}$ used a commercial internet-based search engine (LexisNexis Congressional Index) to search for references to NIST and NBS in electronic versions of the CFR (Appendix 3) and in the regulatory indices of California and Texas. He found 519 citations, but due to the nature of the search algorithm, many references were of an administrative nature; others were references that have been deleted or replaced, but still listed under their original citation. These results, organized by the number of citations per title, are provided in Appendix 4.

\subsection{Data used for this study}

References from the two studies cited above were combined to create an initial data set for the current study. The authors reviewed and eliminated from the combined data set any duplicated references, references that were administrative in nature, and references that have been deleted or replaced.

Table 1 summarizes the resulting data set, listing the title where the reference is found, the department or agency referring to NIST/NBS, and the number of references. After comparison and review, a total of 376 references to NIST/NBS products and services were identified. To facilitate accessing specific information, readers may consult Appendices 5 through 21 which provide information sorted by product or service. The full listing is presented, by CFR title, in Appendix 22.

\footnotetext{
${ }^{2}$ I. Martinez and C. DeVaux, "References to the National Institute of Standards and Technology, NIST, and/or the National Bureau of Standards, NBS, in the Code of Federal Regulations", NIST, Gaithersburg, 2003

${ }^{3}$ T. A. Aanstoos, "Standards Citations in the Code of Federal Regulations", Final Report, September 2003.
} 


\section{Table 1. References to NIST/NBS Products and Services by CFR Title and Department/Agency}

\begin{tabular}{|c|c|c|}
\hline $\begin{array}{l}\text { CFR } \\
\text { Title }\end{array}$ & Name of the CFR Title & $\begin{array}{l}\text { Number of } \\
\text { references }\end{array}$ \\
\hline 5 & Office of Personnel Management & 2 \\
\hline 7 & Department of Agriculture (Standards, Inspections, Marketing Practices) & 1 \\
\hline 7 & $\begin{array}{l}\text { Department of Agriculture / Grain Inspection, Packers and Stockyards } \\
\text { Administration }\end{array}$ & 4 \\
\hline 9 & $\begin{array}{l}\text { Department of Agriculture / Grain Inspection, Packers and Stockyards } \\
\text { Administration }\end{array}$ & 1 \\
\hline 9 & Department of Agriculture / Food Safety and Inspection Service & 13 \\
\hline 10 & Nuclear Regulatory Commission & 4 \\
\hline 10 & Department of Energy & 1 \\
\hline 10 & Department of Energy (Energy Efficiency) & 2 \\
\hline 10 & Department of Energy (Energy Conservation) & 2 \\
\hline 14 & Department of Transportation / Federal Aviation Administration & 6 \\
\hline 15 & $\begin{array}{l}\text { Department of Commerce / National Institute of Standards and } \\
\text { Technology }\end{array}$ & 7 \\
\hline 16 & Consumer Product Safety Commission & 5 \\
\hline 16 & Federal Trade Commission & 3 \\
\hline 18 & Department of Energy / Federal Energy Regulatory Commission & 2 \\
\hline 21 & Dept. of Health and Human Services / Food and Drug Administration & 14 \\
\hline 22 & Foreign Relations / International Boundary and Water Commission & 1 \\
\hline 24 & Housing and Urban Development & 13 \\
\hline 25 & Bureau of Indian Affairs & 3 \\
\hline 28 & Judicial Administration & 1 \\
\hline 29 & Department of Labor / Occupational Safety and Health Administration & 13 \\
\hline 29 & Department of Labor (Wage and Hourly Division) & 1 \\
\hline 29 & Department of Labor / Mine Safety and Health Administration & 8 \\
\hline 31 & Treasury & 1 \\
\hline 32 & Department of Defense & 1 \\
\hline 40 & Environmental Protection Agency & 198 \\
\hline 41 & Public Contracts and Property Maintenance & 1 \\
\hline 43 & Department of the Interior & 1 \\
\hline 45 & Department of Health and Human Services & 2 \\
\hline 46 & Department of Homeland Security / US Coast Guard & 40 \\
\hline 46 & Department of Transportation / Maritime Administration & 1 \\
\hline 47 & Federal Communication Commission & 12 \\
\hline 48 & Department of Energy & 1 \\
\hline 49 & $\begin{array}{l}\text { Department of Transportation / Research and Special Programs } \\
\text { Administration }\end{array}$ & 4 \\
\hline 49 & $\begin{array}{l}\text { Department of Transportation / Federal Motor Carrier Safety } \\
\text { Administration }\end{array}$ & 2 \\
\hline 49 & $\begin{array}{l}\text { Department of Transportation / National Highway Traffic Safety } \\
\text { Administration }\end{array}$ & 5 \\
\hline
\end{tabular}


On review of the references and their context, the authors of this study classified the NIST/NBS products and services broadly identified in the CFR as:
(a) references related to traceability and calibration;
(b) Standard Reference Materials (SRM);
(c) NBS/NIST Special Publications;
(d) assorted publications;
(e) weights and measures handbooks;
(f) references to the National Voluntary Laboratory Accreditation Program (NVLAP) and the National Voluntary Conformity Assessment System Evaluation Program (NVCASE);
(g) Voluntary Product Standards (VPS) and Commercial Standards (CS);
(h) computer security;
(i) Circular 484;
(j) other handbooks; and
(k) the National Technology Transfer and Advancement Act (NTTAA).

Table 2 lists the number of references in each category in order of the number of times each product/service is cited. The majority of references are related to traceability and calibration services. It is important to note that some citations may be construed to refer to more than one NIST product or service; the authors of this study chose to classify those ambiguous references in what was judged the most important and pertinent category. For example, a citation requiring the use of SRM for calibration of an analytical instrument to ensure traceability to a NIST standard would be listed under the SRM category, rather than under traceability or calibration.

Table 2. Distribution of Citations by Category

\begin{tabular}{|l|c|c|}
\hline Product/Service Category & $\begin{array}{c}\text { Number of } \\
\text { Citations }\end{array}$ & $\begin{array}{c}\text { Number of } \\
\text { agencies } \\
\text { referring }\end{array}$ \\
\hline Traceability and Calibration & 188 & 10 \\
\hline Standard Reference Materials (SRM) & 34 & 4 \\
\hline Special Publications (250, 260, 440, 442, 500-172) & 31 & 5 \\
\hline Assorted Publications & 28 & 8 \\
\hline $\begin{array}{l}\text { Weights and Measures Handbooks (44, 105-1 and } \\
\text { 133) }\end{array}$ & 22 & 5 \\
\hline Accreditation, NVLAP \& NVCASE & 19 & 6 \\
\hline $\begin{array}{l}\text { Voluntary Product Standards and Commercial } \\
\text { Standards }\end{array}$ & 12 & 4 \\
\hline Computer Security & 12 & 10 \\
\hline Circular 484 & 7 & 1 \\
\hline Handbook 69 & 6 & 4 \\
\hline Handbook 28 & 5 & 2 \\
\hline Handbook 81 & 3 & 1 \\
\hline National Technology Transfer and Advancement & & 1 \\
\hline
\end{tabular}




\begin{tabular}{|l|l|l|}
\hline Act (NTTAA) & & \\
\hline Handbook 91 & 2 & 1 \\
\hline Handbook 96 & 2 & 2 \\
\hline Handbook 150 & 2 & 1 \\
\hline Handbook 136 & 1 & 1 \\
\hline
\end{tabular}

Appendices 5 through 21 provide a complete listing of references as classified in the categories indicated above. The compiled list of all references can be seen in Appendix 22. The following section is a detailed analysis of these references.

\section{Analysis of NIST in CFR references}

This section provides an overview of the citations by category.

\subsection{Traceability and Calibration}

A majority of the citations to NIST in the CFR are to NIST/NBS products and services for establishing traceability or for calibration services. Appendix 5 indicates 188 references within this category, distributed among 10 departments/agencies, with 158 references by the EPA alone.

The scope of the references to NIST traceability and calibration services varies broadly among agencies. USDA/GIPSA refers to the NBS program for the Certification of Capability of State Measurement Laboratories regarding approval by the Grain Inspection, Packers and Stockyard Administration as qualified metrology labs and Type Evaluation Laboratories. The CPSC generically cites the NBS calibration service as a requirement for calibrating total flux meters used to measure critical radiant flux. The FDA requires microphone calibration to be traceable to the NBS as a requirement for audiometer calibration set for use with diagnostic devices, particularly Ear, Nose and Throat devices. Under the Mammography Quality Standards Act, the FDA defines an instrument being "traceable to a national standard" if it is calibrated either at NIST or at a calibration laboratory that participates in a proficiency program with NIST. HUD requires that each laboratory "provide a description of the applicable standards and calibration equipment being used and the calibration procedures followed, including National Bureau of Standards traceability, when applicable". The Bureau of Indian Affairs requires that all weights and measures shall "conform to standards set by the National Bureau of Standards and to standards, if any, set by the tribe and, if not in conflict with tribal regulations, to the standards set by the State".

OSHA mandates the use of the NBS 9A coupler for acoustic calibration of audiometers. It requires that test equipment for gear certification be tested for accuracy using calibration equipment whose "indications are traceable to the National Bureau of Standards". As part of the quality assurance requirements for testing by third party or applicants, instruments used for the inspection and testing of critical characteristics must be calibrated at least as frequently as, and according to, the instrument manufacturer's specifications, "using calibration standards traceable to those set by the National Bureau of Standards". For test equipment requirements of diesel engines intended for use in 
underground coal mines, MSHA requires span gas and calibration gas values to be traceable to NIST SRMs. Similarly, MSHA requires that light measuring instruments shall be calibrated against standards traceable to the National Bureau of Standards. The U.S. Coast Guard requires that inspection, testing and retesting of deck coverings, structural insulation and bulkhead panels for merchant vessels be conducted at NBS or other laboratories designated by the Coast Guard. The FCC, in its regulations applicable to all broadcast stations for carrier frequency measurements, stipulates that "the primary standard of frequency for radio frequency measurements is the standard frequency maintained by the National Bureau of Standards or the standard signals of Stations WWV, WWVB, and WWVH of the National Bureau of Standards".

EPA references NIST/NBS traceability and calibration products over a broad spectrum of applications. Under the general provisions of the Air Program's Ambient Air Quality Surveillance, EPA defines traceable as "a local standard that has been compared and certified, either directly, or via not more than one intermediate standard, to a National Institute of Standards and Technology (NIST)-certified primary standard such as a NISTTraceable Reference Material (NTRM) or a NIST-certified Gas Manufacturer's Intermediate Standard (GMIS)". EPA also refers to NIST to define a NIST-EPA approved Certified Reference Material, Research Gas Material, and Research Gas Mixture. Repeated references to these products indicate their importance in satisfying a critical requirement for the EPA. Calibration and span gases must be compared with NIST gas standards (with traceability) to ensure that the analytical gases used for testing or calibrating the test equipment meet accuracy and purity specifications. EPA defines a stock solution as one that is made with a reference material traceable to NIST. Some references require the traceability to specific standards, as in the National Primary and Secondary Ambient Air Quality Standards, requiring that the gases used in calibration procedures be traceable to a NBS carbon monoxide-in-air SRM. Other references are more general, as in the inspection/maintenance program requirements of Air Programs, which state that "span and zero gases should be traceable to National Bureau of Standards reference gases" whenever these reference gases are available. Similarly, other regulations require flow calibration devices to be traceable to NIST to ensure accuracy of the devices (Continuous Emissions Monitoring Program, Air Pollution Controls).

In addition to requiring traceability of gases to NIST standards, EPA regulations also require traceability of calibration weights to NIST standards, which are used for calibrating torque measuring devices. Under the National Emission Standards for Hazardous Air Pollutants for Source Categories Program, numerous citations require reference temperature monitors to be traceable to NIST standards used in sterilization facilities. Under the Primary and Secondary Ambient Air Quality Standards, EPA requires both traceability to NIST for measuring instruments, and the use of standards that are traceable to NBS SRMs or an NBS/EPA-approved commercially available Certified Reference Material (CRM).

Under the Air Quality Programs, through the Standards for Performance for New Stationary Sources, EPA requires that spectrophotometers have a NIST-traceable calibration as a minimum design specification, and in the case of the Fourier Transform

\section{Appendix 1}


Infra-Red Spectrometers (FT-IR), the performance specifications require the use of gaseous audit samples comprised of components whose concentrations are traceable to NIST standards. Similarly, regulations covering continuous emissions monitoring require the use of reference values from NIST traceable equipment, and regulations covering the Acid Rain Program require certificates showing traceability to NIST protocols and other supporting documents. EPA regulations also require that equipment used in dew point measurements be traceable to NIST standards and that certification and calibration for microbalances be NIST traceable. Extensive references to NIST products and services are also found in Emission Regulations for New Otto-Cycle and Diesel Heavy-Duty Engines; Gaseous and Exhaust Test Procedures.

'NIST True Value' for purposes of torque calibration is defined by EPA as "the torque calculated by taking the product of a NIST traceable weight or force and a sufficiently horizontal distance along a lever arm, corrected for the lever arm's hanging torque"(Air Pollution Control Programs). However, true value, in general, is defined by NIST as the value consistent with the definition of a given quantity, i.e., a value that would be obtained by a perfect measurement, and hence by nature is indeterminate ${ }^{4}$. Thus while NIST recognizes a "true value" to be indeterminate, a NIST traceable value is referred to by EPA as the "NIST true value". This inconsistency is further compounded by EPA's definition of the term 'accuracy' as "the maximum difference between a measured or calculated value and the true value, where the true value is determined by NIST" (40 CFR 1065.1001). A different approach to the question of NBS true value is seen in the Emission Regulations for New Otto-Cycle and Diesel Heavy-Duty Engines; Gaseous And Particulate Exhaust Test Procedures, where the regulations require that flowmeter calibration be traceable to NBS, and further specify that value to serve as the reference value (i.e., the NBS true value). In addition, the EPA test procedure and equipment requirement under the Air Pollution Control Program which exempts the need for approvals to be sought for using international calibration standards if the "standards have been shown to be traceable to NIST standards".

\subsection{Standard Reference Materials (SRMs)}

Standard Reference Materials (SRMs) are referred to in the CFR by DoL/OSHA, the EPA, and DoT/NHTSA (Appendix 6). The citations are either to specific SRMs or to SRMs in general. A specific citation is the reference to SRM 2670 by DoL/OSHA as a possible source of reference materials available for use in Quality Control/Quality Assurance (QC/QA) analyses of cadmium in urine under the Occupational Safety and Health Standards for Hazardous and Toxic Technology. As a generic citation, EPA refers to SRMs as a source of calibration gases that can be used to meet the specifications and test procedures for continuous emissions monitoring.

DoT/NHTSA, as part of its regulations for Federal Motor Vehicle Safety Standards for motor vehicle brake fluids, requires the use of zinc oxide, oil furnace back and sulfur used in the formulation of rubber compound for making styrene-butadiene rubber brake cups for testing motor vehicle brake fluids. The standard stipulates the concentration of

${ }^{4}$ J. Randa, NIST Project on Standard Terminology for Microwave Radiometry (2002), page 6. 
components used for making the brake cups, and requires that zinc oxide, oil furnace black and sulfur used in such formulations have properties identical to NBS 370 (zinc oxide), NBS 378 (oil furnace black) and NBS 371 (sulfur) as materials supplied by the National Bureau of Standards. These materials are not currently listed in NIST databases and are not available from NIST.

HHS/FDA cites NBS Material 577 as part of the test for compliance that food additive combustion product gas may be safely used in the processing and packaging of the foods, using spectrophotometric measurements. However, this reference material, too, is not available from NIST.

EPA depends substantially on several NIST products and services for the enforcement of its regulations. EPA's Air Programs and the Toxic Substances Control Act refer extensively to NBS and NIST Standard Reference Materials to be used in calibrating devices that must show traceability to NIST. The EPA defines traceability as a "local standard that has been compared and certified either directly or via not more that one intermediate standard, to a primary standard such as a National Bureau of Standards Standard Reference Material (NBS SRM) or a USEPA/NBS-approved Certified Reference Material (CRM)". Under the National Primary and Secondary Ambient Air Quality Standards, permeation devices used for determination of sulfur dioxide in the atmosphere should be traceable to SRMs 1625, 1626 and 1627, and similarly calibration procedures for the measurement of nitrogen oxide and nitrogen dioxide (NOx gases) requires that permeation devices must be calibrated with a reference standard that is traceable to SRM 1683 or SRM 1684 (for NO) and SRM 1629 for NO2.

EPA also cites SRM 930D related to spectrophotometer calibration and the use of NBS SRM 1876 and RM 8410 as a measure of accuracy and comparability in Transmission Electron Microscopy for asbestos-related analyses.

NIST SRMs form the basis for EPA's definition of Standard Reference Materialequivalent compressed gas primary reference material (SRM-equivalent PRM). Furthermore, EPA requires that working and transfer standards and equipment used for auditing must be different from the standards and equipment used for calibration and spanning, but may still refer to the same NIST SRM, CRM, etc.

References to NIST standards are also found in EPA procedures related to gaseous exhaust test methods for emissions regulation, and for gasoline-fueled and diesel-fueled heavy duty engines, where SRMs are used as calibration and span gases, or where the gases used for such purposes must be derived from NBS SRMs. Similar requirements are also included in emission test equipment provisions for control of emissions from nonroad spark-ignition engines at or below $19 \mathrm{~kW}$.

SRM 1627 and 1629 are not listed in the NIST SRM database. SRMs 1625, 1626, 1683 and 1684 are listed, but are flagged as being "out of stock". SRM 1876 was superseded by $1876 \mathrm{~b}$, which also is out of stock. There is no information on RM 8410, but RM 8411 is listed as being out of stock. NBS 370, 371, 372, 378, 384 and 577 are either out of 
stock or not listed. SRM 930D is available as SRM 930e and SRM 1582 as well as SRM 2670 are available. Out of 18 specifically numbered SRMs cited, only 3 are available.

Table 3 below summarizes this information.

Table 3 - Availability of SRMs that are specifically identified by number in the CFR, per search in NIST SRM catalog, www.ts.nist.gov/srm

\begin{tabular}{|c|c|c|c|}
\hline SRM number & SRM on & Availability & Comments \\
\hline NBS 370 & Zinc oxide & No & \\
\hline NBS 371 & Sulfur & No & \\
\hline NBS 372 & Stearic acid & No record found & \\
\hline NBS 378 & Oil furnace black & No record found & \\
\hline NBS 384 & $\begin{array}{l}\text { n-tertiary butyl 2- } \\
\text { benzothiazole } \\
\text { sulfenamide }\end{array}$ & No & \\
\hline NBS 577 & $\begin{array}{l}\text { Absorbance of } \\
\text { naphthalene }\end{array}$ & No & $\begin{array}{l}\text { Search revealed SRM } \\
1577 \mathrm{c} \text { for bovine liver }\end{array}$ \\
\hline SRM 930D & $\begin{array}{l}\text { Luminous } \\
\text { transmittance }\end{array}$ & Yes & Replaced by 930 e \\
\hline SRM 1582 & Petroleum crude oil & Yes & Petroleum crude oil \\
\hline NBS SRM 1625 & $\begin{array}{l}\text { Permeation device to } \\
\text { measure sulfur } \\
\text { dioxide in the } \\
\text { atmosphere }\end{array}$ & No & $\begin{array}{l}\text { SO2 permeation tube } 10 \\
\mathrm{~mm}-\text { out of stock }\end{array}$ \\
\hline NBS SRM 1626 & $\begin{array}{l}\text { Permeation device to } \\
\text { measure sulfur } \\
\text { dioxide in the } \\
\text { atmosphere }\end{array}$ & No & $\begin{array}{l}\mathrm{SO} 2 \text { permeation tube } 5 \\
\mathrm{~mm}-\text { out of stock }\end{array}$ \\
\hline NBS SRM 1627 & $\begin{array}{l}\text { Permeation device to } \\
\text { measure sulfur } \\
\text { dioxide in the } \\
\text { atmosphere }\end{array}$ & No record found & \\
\hline NBS SRM 1629 & $\mathrm{NO} 2$ & No record found & \\
\hline NBS SRM 1683 & $\mathrm{NO}$ in $\mathrm{N} 2$ & No & $\begin{array}{l}\text { Search revealed SRM } \\
1683 \mathrm{~b} \text { on } \mathrm{NO} / \mathrm{N} 2,50 \\
\mu \mathrm{mol} / \mathrm{mo}-\text { out of stock }\end{array}$ \\
\hline NBS SRM 1684 & $\mathrm{NO}$ in $\mathrm{N} 2$ & No & $\begin{array}{l}\text { Search revealed SRM } \\
1684 \mathrm{~b} \text { on } \mathrm{NO} / \mathrm{N} 2,100\end{array}$ \\
\hline
\end{tabular}




\begin{tabular}{|c|c|c|c|}
\hline & & & $\mu \mathrm{mol} / \mathrm{mo}-$ out of stock \\
\hline NBS SRM 1876 & $\begin{array}{l}\text { Microscopy method } \\
\text { for asbestos }\end{array}$ & No & $\begin{array}{l}\text { Search revealed SRM } \\
1876 \text { b on chrysolite } \\
\text { asbestos - out of stock }\end{array}$ \\
\hline RM 8410 & $\begin{array}{l}\text { Microscopy method } \\
\text { for asbestos }\end{array}$ & No record found & \\
\hline RM 8411 & $\begin{array}{l}\text { Microscopy method } \\
\text { for asbestos }\end{array}$ & No & $\begin{array}{l}\text { SRM } 8411 \text { is for mixed } \\
\text { asbestos research filter - } \\
\text { out of stock }\end{array}$ \\
\hline SRM 2670 & Cadmium in urine & Yes & $\begin{array}{l}\text { Superseded by } 2670 \mathrm{a} \text {. } \\
\text { Toxic elements in urine } \\
\text { (freeze-dried) }\end{array}$ \\
\hline
\end{tabular}

\subsection{Special Publications}

DoL/OSHA cites once the 1977 NBS publication on polarized light microscopy of asbestos.

EPA has a total of four citations of NBS Special Publications: three to the 1978 NBS SP506 on misidentification of asbestos in talc, and two to the 1976 NBS SP 442 on organic chemical analysis for municipal and industrial wastewater.

The DHS/USCG has 20 references to the 1976 NBS Special Publication 440, a dictionary of color names.

Two copies of SP 506 are available at NIST. There is a holding related to SP442 which is a 1983 supplement to the Manual on Water, sponsored by ASTM Committee D19. Two copies of SP 440 are available at NIST.

Appendix 7 shows the references to Special Publications.

\subsection{Assorted Publications}

A wide variety of NBS/NIST publications are grouped in this category.

The DoE, part on energy management and planning programs, cites a NIST 1985 publication on life cycle costing.

FTC cites three times a 1995 NIST publication on testing of engine oil, making its requirements mandatory.

FERC cites once a 1984 NBS publication on seismic review of liquid natural gas facilities. 
HUD cites once for its minimum property standards a 1970 NBS publication on the flammability testing of textile floor coverings. The test method is also available as an ASTM standard.

DoL/OSHA cites five NBS publications from 1980-1983 that help understand some requirements for accident prevention signs and tags. With the same purpose, there is a citation for 1978 NBS publication on fire alarms and communication systems.

Two undated NBS reports are cited by OSHA as a source of definitions in classifying soils and rocks deposits and for shoring and sloping of trenches and excavations.

EPA has five citations to three NBS documents. The first is to an undated report on standard reference powder refraction patterns; two are to a 1986 report on the aqueous solubility of organic compounds; and two are for the 1981 report on the same subject.

USCG has nine references to three publications. The 1956 NBS Report 4792 on a test to evaluate smoke signals is cited five times. An undated NBS Simplified Practice on first aid kits is cited three times. One citation refers to an undated NBS report on tests on fire extinguishers.

FCC cites three times a 1967 NBS technical note on calculating the PCS signal levels at microwave receivers.

These references are listed in Appendix 8.

\subsection{Weights and Measures Handbooks (Handbook 44, 105-1 and 133).}

Handbook 44, a NIST publication that provides specifications, tolerances and other technical requirements for weighing and measuring devices, is referenced 15 times in the CFR, mostly by the Department of Agriculture in both titles 7 and 9. FDA and EPA also cite this handbook. In title 7, there is one reference in the Agricultural Marketing Service chapter, under part 58 for dairy plants and products, and two references in the Food Grain Inspection Service chapter, parts 801 and 802 on weighing equipment. In title 9, there is one reference in part 201 for the regulations under the Packers and Stockyards Act, four references in the Food Safety and Inspection Service chapter, part 317 on labeling and marking and three additional references in part 381 on poultry products.

FDA cites Handbook 44 three times under part 1 on general enforcement regulations, and EPA cites it once in part 63 on emissions standards for monitoring requirements.

Handbook 44 is published yearly, and has been issued 25 times since 1979. It is available in hard copy and on-line from the NIST Weights and Measures Division web site at http://ts.nist.gov/ts/htdocs/230/235/pubs.htm.

Handbook 133, a NIST publication on checking the net contents of packaged goods, is referenced six times by the USDA/FSIS in its part 317 on labeling and marking and in 
part 381 on poultry inspection regulations and subpart on procedures for net weight compliance. Two of the USDA citations make the Third Edition of Handbook 133 mandatory; the other four exclude specific chapters of Handbook 133 that are irrelevant to USDA regulations.

Handbook 133 has been published in four editions. The most recent is the January 2005 version of the 4th Edition that was published in 2004 and is available at http://ts.nist.gov/ts/htdocs/230/235/pubs.htm . The 1988 version referenced in the CFR is available for review at the Weights and Measures Division of NIST.

Handbook 105-1, a 1990 NIST publication on the specifications and tolerances for reference standard and field standard weight and measures (NIST Class F), is referenced once by the USDA's Grain Inspection, Packers and Stockyards Inspection (Federal Grain Inspection Service) and is incorporated by reference.

Handbook 105-1 is available from the NIST Weights and Measures Division web site and can be downloaded at http://ts.nist.gov/ts/htdocs/230/235/labmetrologypage.htm

References to Handbooks 44, 105-1 and 133 and their complete titles are included in Appendix 9.

\subsection{Accreditation, the National Voluntary Laboratory Accreditation Program (NVLAP), and, the National Voluntary Conformity Assessment System Evaluation (NVCASE)}

One reference under the DoE's part 431 for the energy efficiency of certain commercial and industrial products cites NVLAP.

Two references under the title 15 chapter on NIST, part 280 pertain to the Fastener Quality Act.

HUD has three citations to NVLAP in part 200 on FHA (Federal Housing

Administration) programs. The first reference states that its building product certification requirements may require accreditation of laboratories by programs such as NVLAP. The second and third refer to periodic carpet testing in a NVLAP-accredited laboratory.

DoL/OSHA cites NVLAP once in its part on asbestos to require testing in a 'nationally recognized testing program' such as a NVLAP-accredited laboratory.

EPA cites NBS-accredited laboratories for testing asbestos for school programs.

FCC cites NIST and NIST programs seven times. Three references are in part 2, subpart on equipment authorization procedures, in the sections on designation and on authorization of Telecommunications Certification Bodies (TCB). The other four are in part 68 on connections of terminal equipment to the telephone network, subparts on conditions on use of terminal equipment, sections on the designation and requirements 
for telecommunications certification bodies (TCBs). The NVCASE program, NIST roles, and the NIST accreditation program are recognized. However, NVLAP is not specifically mentioned; rather the reference is to accreditation under the NVCASE program.

These references to NVLAP and NVCASE are shown in Appendix 10.

\subsection{Voluntary Product Standards and Commercial Standards}

NIST is an active participant in standards development, but, in general, does not develop standards. Two exemptions to this are the development of Computer Security Guidelines/standards for use by the federal government (known as Federal Information Processing Standards) and the development of certain Voluntary Product Standards (VPS). The Department of Commerce is authorized to sponsor voluntary Product Standards development through 15 CFR 10 (b), which defines the requirements for DoC to sponsor Voluntary Product Standards development, and also defines the role of DoC in such a process, granting NIST the authority to administer these procedures for the department.

VPS 36-70 and VPS 54-72 define apparel sizes for boys and girls, respectively. They are cited by the CPSC in defining tight-fitting with respect to the flammability of children's sleepwear. However, these standards are no longer valid. Paper copies are available at the National Center for Standards and Certification Information (NCSCI) at NIST.

HHS/FDA, in the part on animal food labeling, makes a general reference that if a NBS voluntary product standard exists for the number of servings, any label under FDA regulation shall use it.

HUD has eight citations to the following standards in the HUD Minimum Property Standards. PS 1-83 relates to construction and industrial plywood and PS 2-92 gives performance requirements for wood-based structural panels. VPS 20-94 provides requirements on grade marking and is cited once by HUD. CS 136-55 is on insect wire screening and CS 242-62 relates to steel doors and frames.

PS 1-83 is no longer valid and has been superseded by PS 1-95. VPS 20-94 is no longer valid and has been replaced by PS 2-92 and PS 20-99. The current versions are available electronically at the NIST/TS web site http://ts.nist.gov/ts/htdocs/210/sccg/sccg.htm. CS 136-55 and CS 242-62 are no longer valid. Paper copies of withdrawn standards are available at NIST/NCSCI.

DoL/OSHA cites CS 202-56 on industrial lifts and loading ramps once. However, CS $202-56$ has been withdrawn and is no longer valid. Paper copies are available at NIST/NCSCI.

The references to these standards are shown in Appendix 11. 


\subsection{Computer Security}

The Office of Personnel Management makes two references to NIST on computer security. The first is to NIST Special Publication 500-172 on computer security training guidelines, and the second is a general reference to NBS standards on the physical security of automated data processing. SP500-172 has been cancelled.

FERC in a general fashion cites once the NBS guidelines on computer security.

Under the Foreign Relations title of the CFR, in the chapter on International Boundary and Water Commission, US and Mexico Section, the part on the Privacy Act of 1974 there is a citation to the NBS booklet on "Computer Security Guidelines for implementing the Privacy Act of 1974".

Under the Bureau of Indian Affairs title of the CFR, in the chapter on the Navajo and Hopi Indian Relocation, part on Commission Operations and Relocation Procedures, subpart on Privacy Act, there is reference to the NBS booklet on computer security guidelines.

Under the Judicial Administration title of the CFR, in the chapter on the Office of the Independent Counsel, part on the production or disclosure of material or information, there is a reference to consistency with the guidelines developed by NBS for the security of systems of records.

Under the Treasury title of the CFR, there is a reference to the standards promulgated by NBS to ensure maintenance of records under the Privacy Act.

Under the Public Contracts and Property Management title of the CFR, in the chapter on temporary duty travel allowances, part on agency travel accountability requirements, there is reference to the NIST security and privacy requirements for electronic data exchange.

Under the Interior title of the CFR, in the part on records and testimony, subchapter on the Privacy Act, there is reference to the NBS booklet on computer security guidelines.

HHS in the chapter on child support enforcement, part on standards for program operations, both Subpart 7 on provisions of services in interstate cases and Subpart 72 on collection of past-due support by Federal tax refund offset refer to the NIST Federal Information Processing Standards (FIPS) publication. While a specific reference is not mentioned, it may be presumed that it is FIPS Pub 55-DC3 which is available at http://www.its.nist.gov/fipspubs/fip55-3.htm.

Under the Transportation title of the CFR, chapter on the Federal Motor Carrier Safety Administration, part relevant to the hours of service of drivers, the NBS FIPS publication 1-1 is cited for the automatic on-board recording devices. No reference to NIST FIPS Pub 1-1 has been found in the NIST FIPS archives.

Several agencies cite computer security guidelines to implement the 1974 Privacy Act. FIPS Pub 41, which provides these guidelines and is presumably the text referred to by 
the agencies, was withdrawn in 1998. It is still however available at http://www.itl.nist.gov/fipspubs/fips41.pdf

Appendix 12 provides these references.

6.9. Circular 484, a 1949 NBS publication on spectrophotometry, is cited three times by the HHS/FDA in part 172 on permitted food additives, in the sections on petroleum naphtha, on synthetic fatty alcohols and on petroleum wax. It is cited four times in part 178 on indirect food additives, twice in the section on mineral oils, once in the section on polyhydric alcohol esters of oxidatively refined (Gersthofen process) montan wax acids and once in the section on surface lubricants used in the manufacture of metallic articles.

Circular 484 was published only in 1949; one copy is available at NIST.

References to Circular 484 are in Appendix 13.

6.10. Handbook 69 is a 1959 NBS publication on the determination of radiation exposure; four agencies reference it. The NRC references it in the subpart for reactor site criteria and in the subpart for licensing of productions and utilization facilities - technical information. The DoL/WHD cites this handbook under its part on child labor regulations, subpart on occupations particularly hazardous to minors. Both EPA references are in part 141 on national primary drinking water regulations, one under definitions and the other under the maximum contaminant levels and maximum residual disinfectant levels. The DoD refers to Handbook 69 in part 650 on environmental protection and enhancement, subpart on hazardous and toxic materials management.

Handbook 69 was originally published in 1959. Contrary to the EPA citation, the NIST library information does not indicate any 1963 revision. One copy is available at NIST.

References to Handbook 69 are included in Appendix 14.

6.11. Handbook 28, a 1957 NBS publication on screw thread standards, is referenced once by CPSC in relation to attachment hardware for bicycles. It is referenced four times by the DoT/RSPA, once in a general information subpart, twice in the subpart on specifications for packaging used for the transportation of hazardous materials, and once in the subpart for tank cars.

Handbook 28 was originally published in 1939, and then republished in 1942, 1944 with supplements, 1949, and 1950. In 1957, it was issued in three parts, and in 1963 it was republished with one supplement. Seven copies are currently available at NIST.

The CFR references to Handbook 28 are shown in Appendix 15. 
6.12. Handbook 81, a 1961 NBS publication on safety rules for the installation of electrical supply lines, is referenced three times by the DoL/MSHA, under safety and health standards, in its part 56 on surface metal and nonmetal mines and in its part 57 on underground metal and nonmetal mines and for part 77 on surface coal mines and surface work areas of underground coal mines. The subpart on surface high-voltage distribution references the National Electrical Safety Code, which was formerly (?) Handbook 81.

Handbook 81 was originally published in 1941 and then updated in 1961. Both versions were approved by the American Standards Association (the predecessor of the American National Standards Institute, ANSI). Contrary to the MSHA citation, the NIST library information does not indicate any 1968 supplement. One copy is available at NIST.

References to Handbook 81 are provided in Appendix 16.

\subsection{National Technology Transfer and Advancement Act (NTTAA)}

There are three citations in the CFR to the NTTAA, which defines the responsibilities of NIST, those of federal agencies, and those of Agency Standards Executives with respect to the Act.

Appendix 17 lists the references.

6.14. Handbook 91, a 1966 NBS publication on experimental statistics, is referenced twice by the DHS/USCG, part 162 on engineering equipment, subpart on pollution prevention equipment; once as a document incorporated by reference; and once under designation of a facility authorized to perform approval tests.

Handbook 91 was originally published in 1963 and republished with corrections in 1966. Three copies of the 1963 version and five copies of the 1966 version are available at NIST. An updated and expanded version of this handbook is now available as the NIST/SEMATECH e-Handbook of Statistical Methods, http://www.itl.nist.gov/div898/handbook/.

CFR references to Handbook 91 are in Appendix 18.

6.15. Handbook 96, a 1964 NBS publication on inspection of photographic record films for blemishes due to aging, is referenced twice by the DoT. The first reference is by the Maritime Administration in its part 380 on procedures, subpart on records retention schedule. The second is by the Federal Motor Carrier Safety Administration, part 390 on general requirements and information, section on copies of records or documents.

Handbook 96 was published only in 1964; one copy is available at NIST. 
References to Handbook 96 are shown in Appendix 19.

6.16. Handbook 150 and its several supplements provide the procedures and requirements for the NVLAP. Handbook 150-01 is referenced under the DoE's part 430 on the energy conservation program for consumer products program and in part 431 on the energy efficiency program for certain commercial and industrial products under testing laboratories.

Handbook 150 and all its supplements are available for free downloading from the NIST/NVLAP web site at http://ts.nist.gov/ts/htdocs/210/214/214.htm.

References to Handbook 150 are included in Appendix 20.

6.17. Handbook 136, a 1981 publication on radiological safety, is also identified as an American National Standard, ANS N432. It is referenced once by the DoE/NRC, in part 34 on licenses for industrial radiographic operations as a mandatory requirement for equipment performance.

Handbook 136 was published only in 1981; at least one copy is available at NIST.

References to Handbook 136 are listed in Appendix 21.

\section{Availability of NIST Products cited in the CFR}

Information on the availability of SRMs is provided in Table 3 in section 6.2 above. Information on the availability of NIST/NBS publications is provided in Appendix 23.

\section{Conclusions}

From the range of references, it is obvious that U.S. federal agencies have looked, and continue to look, to NIST to provide measurement leadership, along with state-of-the-art products and services for metrology, measurement, laboratory accreditation, conformity assessment and for information technology security. The longevity of some of the identified references clearly indicates NIST's long-standing and essential role measurement science and expertise. Furthermore, the multiple references to numerous NIST products and services attest to their inherent value for many government programs. Thus, it is evident from the extent of the NIST citations in the CFR that U.S. federal agencies rely upon and value highly NIST metrology and measurements expertise. Some important examples include gas standards for use as calibration and span gases and references to NIST Handbook 44.

It should be emphasized that this study did not attempt to measure the impact of specific NIST/NBS products and services or their totality on the U.S. economy. However, NIST impact on the U.S. economy and society is evident through the numerous references by 
U.S. federal agencies to particular NIST products and services. One example is the traceability requirements that EPA includes in their regulations for stationary source, mobile source and ambient air monitoring which has led to a strong demand for NIST SRMs and certification of NIST Traceable Reference Materials (NTRM). To increase the availability of certified gas-mixture reference materials, NIST in collaboration with the EPA and the appropriate specialty gas companies, created the NTRM program. This program has been projected to have net benefits between $\$ 49$ million and $\$ 63$ million from 1990 through 2007, at 2001 dollar value ${ }^{5}$. Another clear example of NIST impact is in EPA regulations that refer to NIST SRMs within the context of measuring the sulfur content of fossil fuels. The economic impact of these SRMs, including benefits accruing from improvement in product quality, production efficiency, and reductions in transaction costs and sulfur dioxide emissions to the environment have been estimated at $\$ 409$ million, beginning in 1984 and projected through 2003, at 1998 dollar value ${ }^{6}$.

There is a wide range of U.S. federal agencies with regulations requiring compliance with NIST guidelines/standards on computer and data security. An economic impact assessment of NIST's Data Encryption Standards program has estimated the impact to be between $\$ 345$ million and $\$ 1.19$ billion (net present value in 2000) ${ }^{7}$. It is important to note that these estimates are for the overall use of NIST's data encryption standards, and include the effect due to federal regulation requirements.

Federal regulations require thermocouple calibration or traceability to NIST. One way to meet this requirement is through the NIST Thermocouple Calibration Program (TCP). An economic impact study of this program found that the internal rate of return from the TCP investments is at least $31.8 \%{ }^{8}$. The study also concluded that this rate of return indicates a socially-valuable activity affecting a broad range of U.S. domestic industries.

The most significant impact of NIST product and services on the U.S. economy is illustrated by the Weights and Measures Handbooks (Handbooks 44, 105-1 and 133) which are cited twenty two times by five agencies (most often USDA). It has been estimated that weights \& measures regulations impact $\$ 4.5$ trillion of commerce or 52\% of the U.S. GDP in 1998 figures. In addition, virtually all states' regulations reference NIST weights and measures handbooks. This also illustrates that a simple numeric count of citations is not an adequate indication to assess the critical importance and/or impact of NIST products.

In general, while numerous references to NIST products, services and publications in the CFR are valid, there are also a number of inaccurate, erroneous, and outdated references. In some instances there are NIST products and services which are cited but not available,

\footnotetext{
${ }^{5}$ The Economic Impact of the Gas-Mixture NIST-Traceable Reference Materials Program (Planning Report \#02-4) http://www.nist.gov/director/planning/impact assessment.htm\#recent

${ }^{6}$ Economic Impact of Standard Reference Materials for Sulfur in Fossil Fuels (Planning Report \#00-1) http://www.nist.gov/director/planning/impact assessment.htm\#recent

${ }^{7}$ The Economic Impacts of NIST's Data Encryption Standard (DES) Program (Planning Report 01-2) http://www.nist.gov/director/planning/impact assessment.htm\#recent

${ }^{8}$ Economic Assessment of the NIST Thermocouple Calibration Program (Planning Report \#97-1 ) http://www.nist.gov/director/planning/impact_assessment.htm\#recent
} 
and in some instances there is no information at NIST about them. Examples are the NIST SRMs that are out of stock, and the references in the CFR to NBS Materials for which there is no available information.

The methodical review of the CFR conducted presents an opportunity for NIST regarding its products and services. NIST should make every effort to assure that up-to-date services are known and available to U.S. government agencies and to industry. To do this, NIST must review thoroughly the current and projected availability of all NIST/NBS products and services cited in CFR references. Additionally, to address specifically the regulatory needs of U.S. federal agencies, NIST should approach regulators to offer its expertise and knowledge and to explain how best to use and reference NIST measurement services and products in their regulations. Specific recommendations are given in section 9 below.

NIST's responsibility to ensure the integrity of the nation's measurement system is a unique and vital component that contributes to the welfare of the nation. Carrying out the recommended actions below will increase NIST's value to U.S. federal agencies, industry and other stakeholders.

\section{Recommendations}

NIST should ensure that its products and services are cited appropriately in regulations and that they are technically valid. Relevant NIST Laboratories should carry out a review to confirm the findings of this study and determine the technical validity of the references. Then, the relevant program responsible for the cited product or service should either identify alternative or new products and services that can serve the purpose of the original citation or other viable options. If NIST Laboratories have followed a deliberate transition strategy for certain products and services, then this information should be documented and presented in a form that is understandable and useful to regulators.

NIST Technology Services can work with NIST Laboratories to evaluate the out-of-date citations identified in this report and determine a course of action for each one. Once NIST has identified alternative resources or confirmed NIST's inability to deliver a cited product and service, NIST must determine the best way to contact regulators and others that may provide support in addressing the technical and administrative issues that were identified.

NIST should approach regulators about: (a) current NIST/NBS products and services that may better suit agencies' needs; (b) the lack of availability of some cited NIST/NBS products, suggesting that they may be inadequate and providing possible replacements for outdated citations; (c) the meaning and significance of traceability and how to demonstrate it, since some regulations specify "traceability to NIST/NBS" or "traceability to NIST standards", without explicitly identifying the required standard to which traceability should be established. 
In addition NIST should support agencies in correcting factual mistakes such as; (a) incorrect references to NIST as the National Institute of/for Science and Technology or the National Institute of/for Standards and Technologies, or still to the National Bureau of Standards; (b) regulations that refer to both NBS and NIST in the same paragraph. The authors note that it may be possible to effect some of these corrections by working directly with the U.S. National Archives and Records Administration (NARA), which is responsible for maintaining an electronic database of the CFR.

Finally, NIST should establish a policy that, in the future, when Laboratories consider termination of a product or service, they should first determine if it is referenced in the CFR and provide appropriate alternatives or work with the relevant agency to change or withdraw particular references.

We believe this is a significant undertaking but one that will enhance the value of NIST products and services to all stakeholders and will clearly identify NIST as the leader of the Nation's Measurement System, which includes responsibilities such as:

- Identifying unmet measurement needs of U.S. industry, commerce, regulatory agencies, and national defense;

- Identifying needed de-facto national standards of measurement;

- Initiating collaborations with and among government agencies and industrial institutions with unmet measurements needs and responding appropriately;

- Developing or collaborating with others on developing measurements, methods and standards to fill identified national measurement needs; and

- Supporting other government agencies with special measurement needs. 


\section{Appendix 1}

Listing of References to NIST and NBS in the Code of Federal Regulations (Martinez and DeVaux)

\begin{tabular}{|c|c|c|c|c|}
\hline Document Number & Title of Document & $\begin{array}{l}\text { Edition } \\
\text { Date }\end{array}$ & $\begin{array}{l}\text { Incorporated } \\
\text { By }\end{array}$ & Location in CFR \\
\hline Security guidelines & $\begin{array}{l}\text { security guidelines for automated systems of } \\
\text { records }\end{array}$ & & $\begin{array}{l}\text { Admin } \\
\text { Personnel }\end{array}$ & 5 CFR 293.107 \\
\hline NBS-SRM 1010a & $\begin{array}{l}\text { Microcopy Resolution Test Chart (ISO Test Chart } \\
\text { No. 2) }\end{array}$ & 1990 & ATBCB & $\begin{array}{l}36 \text { CFR } \\
1230.14(d)(1)(i)\end{array}$ \\
\hline NBS-SRM 1010a & $\begin{array}{l}\text { Microcopy Resolution Test Chart (ISO Test Chart } \\
\text { No. 2) }\end{array}$ & 1990 & ATBCB & 36 CFR 1230.3(d) \\
\hline NBS Calibration & total heat flux meter / radiation instrumentation & & CPSC & 16 CFR 1209.8 \\
\hline PS 36-70 & $\begin{array}{l}\text { Body Measurements for Sizing Boys Apparel } \\
\text { (formerly CS 155-50) }\end{array}$ & 1970 & CPSC & 16 CFR 1616.2(b) \\
\hline PS 54-72 & $\begin{array}{l}\text { Body Measurements for Sizing Girls Apparel } \\
\text { (formerly CS 153-48) }\end{array}$ & 1972 & CPSC & 16 CFR 1616.2(b) \\
\hline Handbook 28 & Screw Thread Standards for Federal Service & & CPSC & 16 CFR 1512.4 \\
\hline Handbook 44 & $\begin{array}{l}\text { Specifications, Tolerances and other Technical } \\
\text { Requirements for Weighing and Measuring } \\
\text { Devices }\end{array}$ & & USDA/FSIS & 9 CFR 317.20 (c) \\
\hline Handbook 44 & $\begin{array}{l}\text { Specifications, Tolerances and other Technical } \\
\text { Requirements for Weighing and Measuring } \\
\text { Devices }\end{array}$ & & USDA/FSIS & 9 CFR 381.121(d) \\
\hline Handbook 44 & $\begin{array}{l}\text { Specifications, Tolerances and other Technical } \\
\text { Requirements for Weighing and Measuring } \\
\text { Devices }\end{array}$ & & USDA/FSIS & 9CFR 317.21 (b) \\
\hline Handbook 133 & $\begin{array}{l}\text { Checking the Net Contents of Packaged Goods, } \\
\text { Third Edition with supplements } 1,2,3 \text {, and } 4 \text { with } \\
\text { the exception of those regulations listed in } 9 \text { CFR } \\
317.19(\mathrm{~b}) \text { and (c) }\end{array}$ & 1988 & USDA/FSIS & 9 CFR 317.19(a) \\
\hline Handbook 133 & $\begin{array}{l}\text { Checking the Net Contents of Packaged Goods, } \\
\text { Third Edition with supplements } 1,2,3 \text {, and } 4 \text { with } \\
\text { the exception of those regulations listed in } 9 \text { CFR } \\
317.19 \text { (b) and (c) }\end{array}$ & 1988 & USDA/FSIS & 9 CFR 381.121b(a) \\
\hline Handbook 44 & $\begin{array}{l}\text { Specifications, Tolerances, and Other Technical } \\
\text { Requirements for Weighing and Measuring } \\
\text { Devices, } 1999 \text { edition }\end{array}$ & 1998 & USDA/FSIS & 9 CFR 317.20(a) \\
\hline Handbook 44 & $\begin{array}{l}\text { Specifications, Tolerances, and Other Technical } \\
\text { Requirements for Weighing and Measuring } \\
\text { Devices, } 1999 \text { edition }\end{array}$ & 1998 & USDA/FSIS & 9 CFR 381.121c(a) \\
\hline Handbook 44 & $\begin{array}{l}\text { Specifications, Tolerances, and Other Technical } \\
\text { Requirements for Weighing and Measuring } \\
\text { Devices, } 1999 \text { edition }\end{array}$ & 1998 & USDA/FSIS & 9 CFR 381.121c(c) \\
\hline Handbook 44 & $\begin{array}{l}\text { Specifications, Tolerances, and Other Technical } \\
\text { Requirements for Weighing and Measuring } \\
\text { Devices }\end{array}$ & 1991 & USDA/GIPSA & 5 CFR 801.12 \\
\hline Handbook 105-1 & $\begin{array}{l}\text { Specifications and Tolerances for Field Standard } \\
\text { Weights }\end{array}$ & 1990 & USDA/GIPSA & 7 CFR 802.0(a) \\
\hline Handbook 44 & $\begin{array}{l}\text { Specifications, Tolerances, and Other Technical } \\
\text { Requirements for Weighing and Measuring } \\
\text { Devices }\end{array}$ & 1990 & USDA/GIPSA & 7 CFR 802.0(a) \\
\hline
\end{tabular}




\begin{tabular}{|c|c|c|c|c|}
\hline Handbook 44 & $\begin{array}{l}\text { Specifications, Tolerances, and other Technical } \\
\text { Requirements for Weighing and Measuring } \\
\text { Devices }\end{array}$ & 1996 & USDA/GIPSA & 9 CFR 201.71(a) \\
\hline $\begin{array}{l}\text { Traceability I } \\
\text { calibration }\end{array}$ & State, county and city metrology labs & & USDA/GIPSA & 7 CFR 802.1 \\
\hline SP 250 & $\begin{array}{l}\text { Calibration and Related Measurement Services of } \\
\text { the National Institute of Standards and Technology }\end{array}$ & NDG & DOC/NIST & 15 CFR 200.115(a) \\
\hline SP 260 & $\begin{array}{l}\text { Catalog of NIST Standard Reference Materials and } \\
\text { Supplement }\end{array}$ & NDG & DOC/NIST & 15 CFR 230.7(a) \\
\hline Handbook 69 & $\begin{array}{l}\text { National Council on Radiation Protection and } \\
\text { Measurement Report N. } 22\end{array}$ & & DOD & 32 CFR 650.139 \\
\hline Handbook 150-01 & $\begin{array}{l}\text { NVLAP Energy Efficient Lighting Products, Lamps } \\
\text { and Luminaries }\end{array}$ & 1993 & $\mathrm{DOE}$ & 10 CFR 430.22 \\
\hline Calibration & Lumen measurements & & DOE & 10 CFR 430.27 \\
\hline Handbook 150-10 & NVLAP Efficiency of Electrical Motors & & DOE & 10 CFR 431.25 \\
\hline NIST 85-3273 & $\begin{array}{l}\text { Life Cycle Costing Manual for Federal Energy } \\
\text { Management Program }\end{array}$ & & DOE & 10 CFR 436.34 \\
\hline Calibration & Calibration services & & DOE & 48 CFR 908.7113 \\
\hline Handbook 136 & $\begin{array}{l}\text { Radiological Safety for the Design and } \\
\text { Construction of Apparatus for Gamma } \\
\text { Radiography }\end{array}$ & 1981 & DOE/NRC & 10 CFR 34.20 \\
\hline NBS Handbook 69 & Radiation exposure & 1959 & DOE/NRC & 10 CFR 100.11 \\
\hline NBS Handbook 69 & Radiation exposure & 1959 & DOE/NRC & 10 CFR 50.34 \\
\hline Handbook 69 & $\begin{array}{l}\text { Maximum Permissible Body Burdens and } \\
\text { Maximum Permissible Concentration of } \\
\text { Radionuclides in Air or Water for Occupational } \\
\text { Exposure }\end{array}$ & & DOE/NRC & 10CFR100.10 \\
\hline Not Stated & $\begin{array}{l}\text { National Electrical Safety Code: Part 2: Safety } \\
\text { Rules for the Installation and Maintenance of } \\
\text { Electric Supply and Communications Lines; and } \\
\text { Supplement } 2 \text { (1968) }\end{array}$ & 1961 & DOL/MSHA & 30 CFR 56.12047 \\
\hline Not Stated & $\begin{array}{l}\text { National Electrical Safety Code: Part 2: Safety } \\
\text { Rules for the Installation and Maintenance of } \\
\text { Electric Supply and Communications Lines; and } \\
\text { Supplement } 2 \text { (1968) }\end{array}$ & 1961 & DOL/MSHA & 30 CFR 57.12047 \\
\hline Not Stated & National Electrical Safety Code & 1971 & DOL/MSHA & 30 CFR $77.807-1$ \\
\hline Traceability & Calibration gas values & & DOL/MSHA & $\begin{array}{l}\text { 30 CFR7.86, } \\
\text { Subpart E }\end{array}$ \\
\hline Traceability & Span gas values & & DOL/MSHA & $\begin{array}{l}30 \text { CFR7.86 } \\
\text { Subpart E }\end{array}$ \\
\hline Calibration & Light measuring instrument & & DOL/MSHA & 30 CFR 75.1719-3 \\
\hline Traceability/Calibration & calibration standards & & DOL/MSHA & 30 CFR 7.7 \\
\hline Traceability/Calibration & calibration standards & & DOL/MSHA & 30 CFR 7.4 \\
\hline
\end{tabular}




\begin{tabular}{|c|c|c|c|c|}
\hline $\begin{array}{l}\text { Laboratory } \\
\text { accreditation }\end{array}$ & NAVLAP Asbestos Program & & DOL/OSHA & 29 CFR 1910.1001 \\
\hline SRM 2670 & Cadmium in urine & & DOL/OSHA & 29 CFR 1910.1027 \\
\hline NBS report & $\begin{array}{l}\text { Recommended Technical Provisions for } \\
\text { Construction Practice in Shoring and Sloping of } \\
\text { Trenches and Excavations }\end{array}$ & & DOL/OSHA & 29 CFR 1926.652 \\
\hline $\begin{array}{l}\text { Laboratory } \\
\text { accreditation }\end{array}$ & $\begin{array}{l}\text { Asbestos - participation in a nationally recognized } \\
\text { testing program such as the National Voluntary } \\
\text { Laboratory Accreditation Program (NVLAP) or the } \\
\text { National Institute for Standards and Technology } \\
\text { (NIST) or the Round Robin for bulk samples }\end{array}$ & & DOL/OSHA & $\begin{array}{l}29 \text { CFR1926 } \\
\text { Subpart Z }\end{array}$ \\
\hline CS 202-56 & Industrial Lifts and Hinged Loading Ramps & 1961 & DOL/OSHA & 29 CFR 1910.30 \\
\hline Traceability/Calibration & recording test equipment calibration & & DOL/OSHA & 29 CFR 1919.60 \\
\hline Calibration & dynamometer calibration & & DOL/OSHA & 29 CFR 1919.10 \\
\hline Handbook 69 & $\begin{array}{l}\text { Maximum Permissible Body Burdens and } \\
\text { Maximum Permissible Concentrations of Radio } \\
\text { Nuclides in Air and in Water for Occupational } \\
\text { Exposure, } 1959\end{array}$ & & DOL/WHD & 29 CFR 570.57 \\
\hline Traceability & Method traceable to NIST & & DOT/FAA & 14CFR A36.3.9.7 \\
\hline Traceability & Method traceable to NIST & & DOT/FAA & 14CFR A36.3.9.10 \\
\hline Calibration & Traceable to NBS & & DOT/FAA & 14CFR H36.101 (7) \\
\hline Calibration & Traceable to NIST & & DOT/FAA & 14CFR J36.109(iii) \\
\hline \multirow[t]{2}{*}{ Calibration } & Traceable to NIST & & DOT/FAA & 14CFR145.47 \\
\hline & $\begin{array}{l}\text { Film for photographing copies, minimum } \\
\text { specifications of NBS }\end{array}$ & & DOT/FMCSA & 49 CFR 390.31 \\
\hline Handbook 96 & $\begin{array}{l}\text { Inspection of Processed Photographic Record } \\
\text { Films for Aging Blemishes }\end{array}$ & & DOT/MA & 46 CFR 380.21 \\
\hline NBS 378 & Oil furnace black / formulation of rubber compound & & DOT/NHTSA & 49 CFR 571 \\
\hline NBS 370 & Zinc oxide / formulation of rubber compound & & DOT/NHTSA & 49 CFR 571 \\
\hline NBS 371 & Sulfur / formulation of rubber compound & & DOT/NHTSA & 49 CFR 571 \\
\hline NBS 372 & Stearic acid / formulation of rubber compound & & DOT/NHTSA & 49 CFR 571 \\
\hline NBS 384 & $\begin{array}{l}\text { n-tertiary butyl-2..../ formulation of rubber } \\
\text { compound }\end{array}$ & & DOT/NHTSA & 49 CFR 571 \\
\hline Calibration & time signals & & DOT/NHTSA & 49 CFR 571.116 \\
\hline Handbook H-28 & $\begin{array}{l}\text { Handbook of Screw-Thread Standards for Federal } \\
\text { Service, Part II, December } 1966 \text { Edition }\end{array}$ & 1957 & DOT/RSPA & 49 CFR 171.7 \\
\hline Handbook H-28 & $\begin{array}{l}\text { Handbook of Screw-Thread Standards for Federal } \\
\text { Service, Part II, December } 1966 \text { Edition }\end{array}$ & 1957 & DOT/RSPA & 49 CFR 178.45 \\
\hline
\end{tabular}




\begin{tabular}{|c|c|c|c|c|}
\hline Handbook H-28 & $\begin{array}{l}\text { Handbook of Screw-Thread Standards for Federal } \\
\text { Service, Part II, December } 1966 \text { Edition }\end{array}$ & 1957 & DOT/RSPA & 49 CFR 178.46 \\
\hline Publication 440 & $\begin{array}{l}\text { Color: Universal Language and Dictionary of } \\
\text { Names }\end{array}$ & 1976 & DOT/USCG & 46 CFR 160.010-1 \\
\hline Publication 440 & Large radius or ASME flow nozzles & 1976 & DOT/USCG & 46 CFR 160.021-1 \\
\hline Publication 440 & $\begin{array}{l}\text { Color: Universal Language and Dictionary of } \\
\text { Names }\end{array}$ & 1976 & DOT/USCG & 46 CFR 160.022-1 \\
\hline Report 4792 & $\begin{array}{l}\text { Development of a Laboratory Test for Evaluation of } \\
\text { the Effectiveness of Smoke Signals }\end{array}$ & 1956 & DOT/USCG & 46 CFR 160.022-1 \\
\hline Publication 440 & $\begin{array}{l}\text { Color: Universal Language and Dictionary of } \\
\text { Names }\end{array}$ & 1976 & DOT/USCG & 46 CFR 160.024-1 \\
\hline Publication 440 & $\begin{array}{l}\text { Color: Universal Language and Dictionary of } \\
\text { Names }\end{array}$ & 1976 & DOT/USCG & 46 CFR 160.036-1 \\
\hline Publication 440 & $\begin{array}{l}\text { Color: Universal Language and Dictionary of } \\
\text { Names }\end{array}$ & 1976 & DOT/USCG & 46 CFR 160.037-1 \\
\hline Report 4792 & $\begin{array}{l}\text { Development of a Laboratory Test for Evaluation of } \\
\text { the Effectiveness of Smoke Signals }\end{array}$ & 1956 & DOT/USCG & 46 CFR 160.037-1 \\
\hline Publication 440 & $\begin{array}{l}\text { Color: Universal Language and Dictionary of } \\
\text { Names }\end{array}$ & 1976 & DOT/USCG & 46 CFR 160.057-1 \\
\hline Report 4792 & $\begin{array}{l}\text { Development of a Laboratory Test for Evaluation of } \\
\text { the Effectiveness of Smoke Signals }\end{array}$ & 1956 & DOT/USCG & 46 CFR 160.057-1 \\
\hline Publication 440 & $\begin{array}{l}\text { Color: Universal Language and Dictionary of } \\
\text { Names }\end{array}$ & 1976 & DOT/USCG & 46 CFR $160.077-5$ \\
\hline Publication 440 & $\begin{array}{l}\text { Color: Universal Language and Dictionary of } \\
\text { Names }\end{array}$ & 1976 & DOT/USCG & 46 CFR 160.151-15 \\
\hline Publication 440 & $\begin{array}{l}\text { Color: Universal Language and Dictionary of } \\
\text { Names }\end{array}$ & 1976 & DOT/USCG & 46 CFR 160.171-3 \\
\hline
\end{tabular}




\begin{tabular}{|c|c|c|c|c|}
\hline Publication 440 & $\begin{array}{l}\text { Color: Universal Language and Dictionary of } \\
\text { Names }\end{array}$ & 1976 & DOT/USCG & 46 CFR $160.174-3$ \\
\hline Publication 440 & $\begin{array}{l}\text { Color: Universal Language and Dictionary of } \\
\text { Names }\end{array}$ & 1976 & DOT/USCG & 46 CFR 160.176-9 \\
\hline Handbook 91 & Experimental Statistics & 1966 & DOT/USCG & 46 CFR 162.050-4 \\
\hline Publication 440 & $\begin{array}{l}\text { Color: Universal Language and Dictionary of } \\
\text { Names }\end{array}$ & 1976 & DOT/USCG & 46 CFR 169.115 \\
\hline & testing - structural insulation & & DOT/USCG & 46 CFR 164.007 \\
\hline & Testing - bulkhead panels & & DOT/USCG & 46 CFR 164.008 \\
\hline & $\begin{array}{l}\text { Inspection and Testing - deck coverings for } \\
\text { merchant vessels }\end{array}$ & & DOT/USCG & 46 CFR 164.006 \\
\hline $\begin{array}{l}\text { Simplified Practice } \\
\text { Recommendation } \\
\text { R178-41 }\end{array}$ & $\begin{array}{l}\text { Packaging of First-Aid Unit Dressings and } \\
\text { Treatments }\end{array}$ & & DOT/USCG & 46 CFR 160.041 \\
\hline SP 440 & $\begin{array}{l}\text { Color: Universal Language and Dictionary of } \\
\text { Names }\end{array}$ & & DOT/USCG & 46 CFR 160.074 \\
\hline $\begin{array}{l}\text { NBS Building } \\
\text { Materials and } \\
\text { Structures Report } 150\end{array}$ & Fire tests, extinguishers, fire, portable, marine type & & DOT/USCG & 46 CFR 162.028 \\
\hline Handbook 44 & $\begin{array}{l}\text { Specifications, Tolerances, and Other Technical } \\
\text { Requirements for Weighing and Measuring } \\
\text { Devices }\end{array}$ & 1998 & EPA & $\begin{array}{l}40 \text { CFR } \\
63.1303(e)(3)\end{array}$ \\
\hline Handbook 69 & $\begin{array}{l}\text { Permissible Body Burdens and Maximum } \\
\text { permissible Concentrations of Radionuclides in Air } \\
\text { or Water for Occupational Exposure }\end{array}$ & 1963 & EPA & 40 CFR 141.16(b) \\
\hline NBS SRM & General requirement & & EPA & 40 CFR Part 50 \\
\hline NBS Calibration & $\begin{array}{l}\text { traceable bubble flowmeter or calibrated wet test } \\
\text { meter }\end{array}$ & & EPA & 40 CFR 50.49 .4 .1 \\
\hline
\end{tabular}




\begin{tabular}{|c|c|c|c|c|}
\hline NBS SRM 1625 & Permeation devices & & EPA & 40 CFR 50.410 .3 \\
\hline NBS SRM 1626 & Permeation devices & & EPA & 40 CFR $50.4 \quad 10.3$ \\
\hline NBS SRM 1627 & Permeation devices & & EPA & 40 CFR 50.410 .3 \\
\hline NBS SRM & $\mathrm{CO}$ in air & & EPA & 40 CFR 50.43 .1 \\
\hline NBS SRM 1683 & NO concentration & & EPA & $\begin{array}{l}40 \text { CFR } 50.4 \text { 1.3, } \\
2.3 .1\end{array}$ \\
\hline NBS SRM 1684 & NO concentration & & EPA & $\begin{array}{l}\text { 40 CFR } 50.41 .3, \\
\text { 2.3.1 }\end{array}$ \\
\hline Calibration /traceability & Flow rate transfer & & EPA & $\begin{array}{l}40 \text { CFR } 50.37 .3, \\
8.2 .2\end{array}$ \\
\hline NBS SP 300 & $\begin{array}{l}\text { Colorimetric Precision Measurement and } \\
\text { Calibration }\end{array}$ & 1972 & EPA & $\begin{array}{l}40 \text { CFR Part } 60 \\
16.00\end{array}$ \\
\hline NBS/EPA publication & $\begin{array}{l}\text { A Procedure for establishing traceability to gas } \\
\text { mixtures to certain National Bureau of Standards } \\
\text { Standard Reference Materials }\end{array}$ & 1981 & EPA & $\begin{array}{l}40 \text { CFR Part } 60 \\
17.00\end{array}$ \\
\hline SRM & Audit gases & & EPA & $\begin{array}{l}40 \text { CFR Part } 60 \\
5.1 .2\end{array}$ \\
\hline NBS-calibration? & Carbon dioxide, methane, xylene & & EPA & 40 CFR 53.22 \\
\hline NBS & reference filters & & EPA & 40 CFR 86.884-11 \\
\hline $\begin{array}{l}\text { Traceability / } \\
\text { calibration }\end{array}$ & NBS value torque & & EPA & 40 CFR $86.1308-84$ \\
\hline $\begin{array}{l}\text { Traceability / } \\
\text { calibration }\end{array}$ & Weights traceable to NIST & & EPA & 40 CFR $86.1308-84$ \\
\hline
\end{tabular}




\begin{tabular}{|c|c|c|c|c|}
\hline NBS/EPA publication & $\begin{array}{l}\text { A Procedure for establishing traceability to gas } \\
\text { mixtures to certain National Bureau of Standards } \\
\text { Standard Reference Materials }\end{array}$ & 1981 & EPA & 40 CFR 58.61 \\
\hline $\begin{array}{l}\text { Traceability / } \\
\text { calibration }\end{array}$ & $\begin{array}{l}\text { Flowmeter calibration or other measurement if } \\
\text { traceable to NBS }\end{array}$ & & EPA & 40 CFR 86.1319-90 \\
\hline $\begin{array}{l}\text { Traceability I } \\
\text { calibration }\end{array}$ & NBS traceable flow calibration & & EPA & 40 CFR 86.1320-90 \\
\hline NBS Handbook 69 & $\begin{array}{l}\text { Maximum Permissible Body Burdens and } \\
\text { Maximum Permissible Concentration of } \\
\text { Radionuclides in Air or Water for Occupational } \\
\text { Exposure }\end{array}$ & & EPA & $\begin{array}{l}40 \text { CFR } 141 \text { Subpart } \\
\text { A }\end{array}$ \\
\hline NBS Handbook 69 & $\begin{array}{l}\text { Maximum Permissible Body Burdens and } \\
\text { Maximum Permissible Concentration of } \\
\text { Radionuclides in Air or Water for Occupational } \\
\text { Exposure }\end{array}$ & 1963 & EPA & 40 CFR 141.66 \\
\hline Traceability & Flow calibration device & & EPA & 40 CFR $86.120-94$ \\
\hline $\begin{array}{l}\text { Traceability / } \\
\text { calibration }\end{array}$ & NBS weights & & EPA & 40 CFR 86.333 .79 \\
\hline Traceability & Calibration gas and span gas & & EPA & 40 CFR $86.301-79$ \\
\hline Traceability & Calibration gas and span gas & & EPA & 40 CFR 86.308-79 \\
\hline $\begin{array}{l}\text { Traceability / } \\
\text { calibration }\end{array}$ & NBS weights & & EPA & 40 CFR $86.312-79$ \\
\hline Traceability & For fuels and fuel additives & & EPA & 40 CFR 80.1045 \\
\hline Traceability & Gaseous pollutant concentration standards & & EPA & 40 CFR58 \\
\hline Traceability & $\begin{array}{l}\text { Gaseous standards used to obtain test } \\
\text { concentrations for } \mathrm{CO}, \mathrm{SO} 2 \text { and } \mathrm{NO} 2\end{array}$ & & EPA & 40 CFR58 \\
\hline Traceability & Flow rate measurement device & & EPA & 40 CFR 53.52 \\
\hline
\end{tabular}




\begin{tabular}{|c|c|c|c|}
\hline Traceability/calibration & all measurement instruments used in the tests & EPA & 40 CFR 53.52 \\
\hline Traceability & Flow rate measurement device & EPA & 40 CFR 53.53 \\
\hline Traceability & Flow rate measurement device & EPA & 40 CFR 53.54 \\
\hline Traceability & Flow rate measurement device & EPA & $\begin{array}{l}40 \text { CFR53, Subpart } \\
\text { E }\end{array}$ \\
\hline Traceability/calibration & all measurement instruments used in the tests & EPA & $\begin{array}{l}40 \text { CFR53, Subpart } \\
\text { E }\end{array}$ \\
\hline Traceability & Flow rate measurement device & EPA & $\begin{array}{l}40 \text { CFR53, Subpart } \\
\text { E }\end{array}$ \\
\hline Traceability/calibration & all measurement instruments used in the tests & EPA & $\begin{array}{l}40 \text { CFR53, Subpart } \\
\text { E }\end{array}$ \\
\hline Traceability & Miniature temperature sensors & EPA & $\begin{array}{l}40 \text { CFR53, Subpart } \\
\text { E }\end{array}$ \\
\hline Traceability/calibration & all measurement instruments used in the tests & EPA & $\begin{array}{l}40 \text { CFR53, Subpart } \\
\text { E }\end{array}$ \\
\hline Traceability/calibration & all relevant measurement equipment & EPA & $\begin{array}{l}40 \text { CFR53, Subpart } \\
\text { A }\end{array}$ \\
\hline Traceability & Flow rate measurement device & EPA & $\begin{array}{l}40 \text { CFR53, Subpart } \\
\text { A }\end{array}$ \\
\hline Traceability & Gases used for calibration, fuel and combustion air & EPA & $\begin{array}{l}40 \text { CFR52.741, } \\
\text { Subpart O }\end{array}$ \\
\hline Traceability & The span gases used for the gas calibration & EPA & $\begin{array}{l}\text { 40 CFR51.373, } \\
\text { Subpart S }\end{array}$ \\
\hline Traceability & flow rate standard & EPA & 40 CFR 50.12 \\
\hline
\end{tabular}




\begin{tabular}{|c|c|c|c|}
\hline Traceability & the accuracy of the temperature monitor & EPA & 40 CFR 63.364 \\
\hline Traceability & verified in calibrated oven traceable to NIST & EPA & 40 CFR 63.364 \\
\hline Traceability & accuracy of the temperature monitor & EPA & $\begin{array}{l}40 \text { CFR } 63.564 \\
\text { (e) (4), (g) (3), (h) } \\
\text { (7) }\end{array}$ \\
\hline Traceability & Equivalent to calibration error (CE) test & EPA & $\begin{array}{l}40 \\
\text { CFR63.1213Subpart } \\
\text { EEE }\end{array}$ \\
\hline Traceability & The device & EPA & $\begin{array}{l}40 \text { CFR63.5545 } \\
\text { Subpart UUUU }\end{array}$ \\
\hline Traceability & Calibration gas values & EPA & 40 CFR72 \\
\hline Traceability & compressed gas calibration standard & EPA & 40 CFR72 \\
\hline Traceability & $\begin{array}{l}\text { transmitter or transducer; } \ldots \text { and expected } \\
\text { transmitter output during accuracy test }\end{array}$ & EPA & $\begin{array}{l}40 \text { CFR75, Subpart } \\
\text { A }\end{array}$ \\
\hline Traceability & $\begin{array}{l}\text { Information demonstrating that the proposed } \\
\text { alternative produces data acceptable for use }\end{array}$ & EPA & $\begin{array}{l}40 \text { CFR75, Subpart } \\
\text { A }\end{array}$ \\
\hline Traceability & calibration gases & EPA & $\begin{array}{l}40 \text { CFR75, Subpart } \\
\text { A }\end{array}$ \\
\hline Traceability & Flowmeter accuracy & EPA & $\begin{array}{l}40 \text { CFR75, Subpart } \\
\text { A }\end{array}$ \\
\hline Traceability & $\begin{array}{l}\text { differential pressure transmitter or transducer, } \\
\text { static pressure transmitter or transducer, and } \\
\text { temperature transmitter or transducer }\end{array}$ & EPA & $\begin{array}{l}40 \text { CFR75, Subpart } \\
\text { A }\end{array}$ \\
\hline Traceability & Calibration gases & EPA & 40 CFR 86.114-94 \\
\hline Traceability & Calibration gases & EPA & 40 CFR $86.1214-85$ \\
\hline
\end{tabular}




\begin{tabular}{|c|c|c|c|}
\hline Traceability & Calibration gases & EPA & 40 CFR 86.1314-94 \\
\hline Traceability & Span gases & EPA & 40 CFR 86.114-94 \\
\hline Traceability & Span gases & EPA & 40 CFR 86.1214-85 \\
\hline Traceability & Span gases & EPA & 40 CFR 86.1314-94 \\
\hline Traceability & Methanol in air gases & EPA & 40 CFR 86-114-94 \\
\hline Traceability & Methanol in air gases & EPA & 40 CFR 86.514-78 \\
\hline Traceability & Methanol in air gases & EPA & 40 CFR 86.1214-85 \\
\hline Traceability & Methanol in air gases & EPA & 40 CFR 86.1314-94 \\
\hline Traceability & known methane in air concentrations & EPA & 40 CFR $86.121-90$ \\
\hline Traceability & known methane in air concentrations & EPA & 40 CFR 86.521-90 \\
\hline Traceability & known methane in air concentrations & EPA & 40 CFR $86.1221-90$ \\
\hline Traceability & known methane in air concentrations & EPA & 40 CFR 86.1314-94 \\
\hline Traceability & known methane in air concentrations & EPA & 40 CFR 86.1321-94 \\
\hline Traceability/calibration & Calibration & EPA & 40 CFR 86.1306-07 \\
\hline
\end{tabular}

\section{Appendix 1}




\begin{tabular}{|c|c|c|c|}
\hline Traceability & Dewpoint shall be measured & EPA & $\begin{array}{l}40 \text { CFR 86.1312- } \\
2007\end{array}$ \\
\hline Traceability/calibration & certification and calibration procedures & EPA & $\begin{array}{l}\text { 40 CFR 86.1312- } \\
2007\end{array}$ \\
\hline Traceability & Dynamometer calibration weights & EPA & 40 CFR 89.306 \\
\hline Traceability & Dynamometer calibration weights & EPA & 40 CFR 91.305 \\
\hline Traceability/calibration & Calibration and span gases & EPA & 40 CFR 89.312 \\
\hline Traceability/calibration & Calibration and span gases & EPA & 40 CFR90 \\
\hline Traceability/calibration & Calibration and span gases & EPA & 40 CFR91.312 \\
\hline Traceability/calibration & Calibration and span gases & EPA & 40 CFR91.314 \\
\hline Traceability/calibration & flowmeter calibration & EPA & 40 CFR89.422 \\
\hline Traceability/calibration & flowmeter calibration & EPA & 40 CFR90.424 \\
\hline Traceability/calibration & flowmeter calibration & EPA & 40 CFR91 \\
\hline Traceability & Other measurement systems may be used & EPA & 40 CFR89.422 \\
\hline Traceability/calibration & Dynamometer calibration weights & EPA & 40 CFR90.305 \\
\hline Traceability/calibration & Calibration gas/span gas & EPA & 40 CFR90.314 \\
\hline
\end{tabular}

\section{Appendix 1}




\begin{tabular}{|c|c|c|c|c|}
\hline Traceability & Large radius or ASME flow nozzles & & EPA & 40 CFR90.424 \\
\hline Traceability & $\begin{array}{l}\text { the true value, where the true value is determined } \\
\text { from NIST traceable measurements }\end{array}$ & & EPA & 40 CFR92 \\
\hline Traceability & Engine flywheel torque readout & & EPA & 40 CFR92 \\
\hline Traceability/calibration & Calibration and span gases & & EPA & 40 CFR92 \\
\hline Traceability & true value torque & & EPA & 40 CFR92 \\
\hline Traceability & Weights & & EPA & 40 CFR92 \\
\hline Traceability/calibration & master load cell & & EPA & 40 CFR92.117 \\
\hline Traceability/calibration & $\begin{array}{l}\text { critical flow orifice, a bellmouth nozzle, or a laminar } \\
\text { flow element or an NIST traceable flow calibration } \\
\text { device is required as the standard device }\end{array}$ & & EPA & 40 CFR92.117 \\
\hline Traceability/calibration & Filters & & EPA & 40 CFR 92.122 \\
\hline Traceability & Gas & & EPA & 40 CFR 92.122 \\
\hline Traceability & solution containing an analyte & & EPA & 40 CFR136 \\
\hline Traceability & Span gas & & EPA & 40 CFR 85.2232 \\
\hline $\begin{array}{l}\text { NBS Technical Note } \\
101\end{array}$ & $\begin{array}{l}\text { Transmission Loss Predictions for Tropospheric } \\
\text { Communication Circuits }\end{array}$ & 1967 & FCC & 47 CFR 24.253 \\
\hline Accreditation & $\begin{array}{l}\text { TCBS shall be accredited by the NIST under its } \\
\text { NVCASE program, or other recognized programs } \\
\text { based on ISO/IEC Guide } 65 \text {, to comply with the } \\
\text { Commission's qualification criteria for TCBs. NIST } \\
\text { may, in accordance with its procedures, allow other }\end{array}$ & & FCC & 47 CFR2 \\
\hline
\end{tabular}




\begin{tabular}{|c|c|c|c|c|}
\hline & $\begin{array}{l}\text { appropriately qualified accrediting bodies to } \\
\text { accredit TCBs and testing laboratories }\end{array}$ & & & \\
\hline Accreditation & $\begin{array}{l}\text { TCBS shall be accredited by the NIST under its } \\
\text { NVCASE program, or other recognized programs } \\
\text { based on ISO/IEC Guide 65, to comply with the } \\
\text { Commission's qualification criteria for TCBs. NIST } \\
\text { may, in accordance with its procedures, allow other } \\
\text { appropriately qualified accrediting bodies to } \\
\text { accredit TCBs and testing laboratories }\end{array}$ & & FCC & 47 CFR68.160 \\
\hline Accreditation & $\begin{array}{l}\text { Commission will designate as a TCB any } \\
\text { organization that meets the qualification criteria } \\
\text { and is accredited by NIST or its recognized } \\
\text { accreditor }\end{array}$ & & FCC & 47 CFR2 \\
\hline Accreditation & $\begin{array}{l}\text { Commission will designate as a TCB any } \\
\text { organization that meets the qualification criteria } \\
\text { and is accredited by NIST or its recognized } \\
\text { accreditor }\end{array}$ & & FCC & 47 CFR68.160 \\
\hline & Time signal rebroadcasts & & FCC & 47 CFR 73.1207 \\
\hline Traceability & Standard radio frequency & & FCC & 47 CFR 73.1540 \\
\hline NBSIR 84-7833 & $\begin{array}{l}\text { Data requirements for the Seismic Review of LNG } \\
\text { facilities }\end{array}$ & & FERC & 18 CFR 153.7 \\
\hline Security guidelines & & & FERC & 18 CFR 36.204 \\
\hline NIST report & Engine Oil Licensing and Certification System & 1995 & FTC & $\begin{array}{l}16 \text { CFR } 311.4 \text { and } \\
311.5\end{array}$ \\
\hline Circular 484 & Spectrophotometry & 1949 & $\mathrm{HHS} / F D A$ & $\begin{array}{l}21 \text { CFR } \\
172.250(b)(3)\end{array}$ \\
\hline Circular 484 & Spectrophotometry & 1949 & $\mathrm{HHS} / F D A$ & 21 CFR 172.886(b) \\
\hline Circular 484 & Spectrophotometry & 1949 & HHS/FDA & $\begin{array}{l}21 \text { CFR } \\
178.3770(a)(4)\end{array}$ \\
\hline Circular 484 & Spectrophotometry & 1949 & HHS/FDA & $\begin{array}{l}21 \text { CFR } \\
178.3910(a)(4)(i i i)\end{array}$ \\
\hline
\end{tabular}




\begin{tabular}{|c|c|c|c|c|}
\hline Handbook 44 & $\begin{array}{l}\text { Measure Container Code, section } 4.45 \text { Measure } \\
\text { Containers }\end{array}$ & NDG & $\mathrm{HHS} / F D A$ & 21 CFR $1.24(a)(6)(i)$ \\
\hline Handbook 44 & $\begin{array}{l}\text { Measure Container Code, section } 4.45 \text { Measure } \\
\text { Containers }\end{array}$ & NDG & HHS/FDA & $\begin{array}{l}21 \text { CFR } \\
1.24(a)(6)(\text { ii) }\end{array}$ \\
\hline Handbook 44 & $\begin{array}{l}\text { Measure Container Code, section } 4.45 \text { Measure } \\
\text { Containers }\end{array}$ & NDG & HHS/FDA & $\begin{array}{l}21 \text { CFR } \\
1.24(\mathrm{a})(6)(\mathrm{iii})\end{array}$ \\
\hline $\begin{array}{l}\text { Traceability / } \\
\text { calibration }\end{array}$ & Mammography equipment & & HHS/FDA & 21 CFR 900.2 \\
\hline & Spectrophotometry & & HHS/FDA & 21 CFR 172.864 \\
\hline Material N. 577 & Naphthalene, combustion product gas & & HHS/FDA & 21 CFR 173.355 \\
\hline Calibration & audiometer calibration set & & HHS/FDA & 21 CFR 874.1080 \\
\hline & Definition of voluntary product standards & & HHS/FDA & 21 CFR 501.8 \\
\hline & Spectrophotometry & & HHS/FDA & 21 CFR 178.3620 \\
\hline Handbook 74 & $\begin{array}{l}\text { Building Code Requirements for Reinforced } \\
\text { Masonry (ANSI A41.2) }\end{array}$ & 1960 & HUD & $\begin{array}{l}24 \text { CFR 200, } \\
\text { Subpart S }\end{array}$ \\
\hline PS 1-74 & $\begin{array}{l}\text { Product Standard for Construction and Industrial } \\
\text { Plywood with Typical APA Trademarks }\end{array}$ & 1974 & HUD & $\begin{array}{l}24 \text { CFR 200, } \\
\text { Subpart S }\end{array}$ \\
\hline PS 1-82 & $\begin{array}{l}\text { Voluntary Product Standard, Construction and } \\
\text { Industrial Plywood }\end{array}$ & 1982 & HUD & $\begin{array}{l}24 \text { CFR } \\
3280.304(b)(1)\end{array}$ \\
\hline CS 138-55 & Insect Wire Screening & 1955 & HUD & $\begin{array}{l}\text { 24 CFR 200, } \\
\text { Appendix A }\end{array}$ \\
\hline CS 242-62 & 1-3/4" Thick Steel Doors and Frames & 1962 & HUD & $\begin{array}{l}24 \text { CFR 200, } \\
\text { Appendix A }\end{array}$ \\
\hline
\end{tabular}




\begin{tabular}{|c|c|c|c|c|}
\hline CS 242-62 & 1-3/4" Thick Steel Doors and Frames & 1962 & HUD & $\begin{array}{l}24 \text { CFR 200, } \\
\text { Subpart S }\end{array}$ \\
\hline FF-1-70 & $\begin{array}{l}\text { Standard Test Method for Flammability of Finished } \\
\text { Textile Floor Covering Materials (ASTM D2859-76) }\end{array}$ & 1970 & HUD & 24 CFR 200.942 \\
\hline PS 1-83 & $\begin{array}{l}\text { Product Standard for Construction and Industrial } \\
\text { Plywood with Typical APA Trademarks }\end{array}$ & 1983 & HUD & $\begin{array}{l}24 \text { CFR 200, } \\
\text { Appendix A }\end{array}$ \\
\hline PS 20-70 & American Softwood Lumber Standard & 1970 & HUD & $\begin{array}{l}\text { 24 CFR 200, } \\
\text { Subpart S }\end{array}$ \\
\hline PS 20-94 & American Softwood Lumber Standard & 1994 & HUD & $\begin{array}{l}24 \text { CFR } \\
200.943(a)(1)\end{array}$ \\
\hline PS 27-70 & Mosaic-Parquet Hardwood Slat Flooring & 1970 & HUD & $\begin{array}{l}24 \text { CFR 200, } \\
\text { Subpart S }\end{array}$ \\
\hline PS 2-92 & $\begin{array}{l}\text { Performance Standard for Wood-Based Structural- } \\
\text { Use Panels }\end{array}$ & 1992 & HUD & $\begin{array}{l}\text { 24 CFR 200, } \\
\text { Appendix A }\end{array}$ \\
\hline PS 51-71 & Hardwood and Decorative Plywood & 1971 & HUD & $\begin{array}{l}24 \text { CFR 200, } \\
\text { Subpart S }\end{array}$ \\
\hline PS 56-73 & Structural Glued Laminated Timber (ANSI A190.1) & 1973 & HUD & $\begin{array}{l}24 \text { CFR 200, } \\
\text { Subpart S }\end{array}$ \\
\hline PS 57-73 & Cellulose Fiber Insulation Board (ANSI A194.1) & 1973 & HUD & $\begin{array}{l}\text { 24 CFR 200, } \\
\text { Subpart S }\end{array}$ \\
\hline PS 58-73 & Basic Hardboard (ANSI A135.4) & 1973 & HUD & $\begin{array}{l}24 \text { CFR 200, } \\
\text { Subpart S }\end{array}$ \\
\hline PS 59-73 & Pre-finished Hardboard Paneling (ANSI A135.5) & 1973 & HUD & $\begin{array}{l}24 \text { CFR 200, } \\
\text { Subpart S }\end{array}$ \\
\hline PS 60-73 & Hardboard Siding (ANSI A135.6) & 1973 & HUD & $\begin{array}{l}24 \text { CFR 200, } \\
\text { Subpart S }\end{array}$ \\
\hline Publication & Dust Spot Method of Testing Air Filters & 1957 & HUD & $\begin{array}{l}24 \text { CFR 200, } \\
\text { Subpart S }\end{array}$ \\
\hline
\end{tabular}




\begin{tabular}{|c|c|c|c|c|}
\hline SP 330 & The International System of Units & 1977 & HUD & $\begin{array}{l}24 \text { CFR 200, } \\
\text { Subpart S }\end{array}$ \\
\hline PS 2-92 & $\begin{array}{l}\text { Performance Standard for Wood-Based Structural- } \\
\text { Use Panels }\end{array}$ & & HUD & 24 CFR 3280.304 \\
\hline VPS 20-94 & American Softwood Lumber Standard & & HUD & 24 CFR 200.943 \\
\hline DOC FF1-70 & $\begin{array}{l}\text { Standard test method for Flammability of Finished } \\
\text { Textile Floor Covering Materials }\end{array}$ & & HUD & 24 CFR 200.942 \\
\hline Accreditation & NVLAP - carpet & & HUD & 24 CFR 200.942 \\
\hline Accreditation & NVLAP - carpet & & HUD & 24 CFR 200.945 \\
\hline VPS PS 1-83 & Construction and Industrial Plywood & & HUD & 24 CFR 200.944 \\
\hline $\begin{array}{l}\text { Computer Security } \\
\text { Guidelines for } \\
\text { Implementing the } \\
\text { Privacy Act of } 1974\end{array}$ & & & Indian Affairs & 25 CFR 43.22 \\
\hline Security Guidelines & & & $\begin{array}{l}\text { Judicial } \\
\text { Administration }\end{array}$ & 28 CFR 700.24 \\
\hline SP 500-172 & Computer Security Training Guidelines & $?$ & OPM & $\begin{array}{l}5 \text { CFR 930, Subpart } \\
\text { C }\end{array}$ \\
\hline Security standards & & & Treasury & 31 CFR 1.22 \\
\hline Security standards & $\begin{array}{l}\text { security and privacy requirements established by } \\
\text { the NIST for electronic data interchange }\end{array}$ & & $\begin{array}{l}\text { Public } \\
\text { Contracts and } \\
\text { Property } \\
\text { Management }\end{array}$ & 41 CFR301-71.3 \\
\hline
\end{tabular}




\section{Appendix 2}

Federal Agencies Referencing NIST and NBS in the Code of Federal Regulations (Martinez and DeVaux)

\begin{tabular}{|c|c|c|c|}
\hline Agency & & & $\begin{array}{l}\text { Number of } \\
\text { References }\end{array}$ \\
\hline 1. Administrative Personnel & & & 1 \\
\hline $\begin{array}{l}\text { 2. Architectural and Transportation Barriers } \\
\text { Compliance Board }\end{array}$ & & ATBCB & 2 \\
\hline 3. Consumer Product Safety Commission & & CPSC & 4 \\
\hline $\begin{array}{l}\text { 4. Department of Agriculture/Food Safety Inspection } \\
\text { Service }\end{array}$ & USDA & FSIS & 8 \\
\hline $\begin{array}{l}\text { 5. Department of Agriculture/Grain Inspection, } \\
\text { Packers and Stockyards Administration }\end{array}$ & USDA & GIPSA & 5 \\
\hline 6. Department of Commerce/NIST & DOC & NIST & 2 \\
\hline 7. Department of Defense & DOD & & 1 \\
\hline 8. Department of Energy & DOE & & 5 \\
\hline $\begin{array}{l}\text { 9. Department of Energy/Nuclear Regulatory } \\
\text { Commission }\end{array}$ & DOE & NRC & 4 \\
\hline $\begin{array}{l}\text { 10. Department of Labor/Mine Safety and Health } \\
\text { Administration }\end{array}$ & DOL & MSHA & 8 \\
\hline $\begin{array}{l}\text { 11. Department of Labor/Occupational Safety and } \\
\text { Health Administration }\end{array}$ & DOL & OSHA & 7 \\
\hline $\begin{array}{l}\text { 12. Department of Labor/Employment Standards } \\
\text { Administration }\end{array}$ & $\overline{\mathrm{DOL}}$ & ESA & 1 \\
\hline $\begin{array}{l}\text { 13. Department of Transportation/Federal Aviation } \\
\text { Administration }\end{array}$ & DOT & FAA & 5 \\
\hline $\begin{array}{l}\text { 14. Department of Transportation /Federal Motor } \\
\text { Carrier Safety Administration }\end{array}$ & DOT & FMCSA & 1 \\
\hline $\begin{array}{l}\text { 15. Department of Transportation/Maritime } \\
\text { Administration }\end{array}$ & DOT & MA & 1 \\
\hline $\begin{array}{l}\text { 16. Department of Transportation/National Highway } \\
\text { and Traffic Safety Administration }\end{array}$ & DOT & NHTSA & 6 \\
\hline $\begin{array}{l}\text { 17. Department of Transportation/Research and } \\
\text { Special Programs Administration }\end{array}$ & DOT & RSPA & 3 \\
\hline 18. Department of Transportation/U.S. Coast Guard & DOT & USCG & 23 \\
\hline 19. Environmental Protection Administration & & EPA & 100 \\
\hline 20. Federal Communications Commission & & FCC & 7 \\
\hline 21. Federal Energy Regulatory Commission & & FERC & 2 \\
\hline 22. Federal Trade Commission & & FTC & 1 \\
\hline $\begin{array}{l}\text { 23. Department of Health and Human Services/Food } \\
\text { and Drug Administration }\end{array}$ & HHS & FDA & 13 \\
\hline 24. Department of Housing and Urban Development & HUD & & 26 \\
\hline 25. Indian Affairs & & & 1 \\
\hline 26. Judicial Administration & & & 1 \\
\hline 27. Office of Personnel Management & & OPM & 1 \\
\hline 28. Department of Treasury & Treasury & & 1 \\
\hline 29. Public Contracts & & & 1 \\
\hline
\end{tabular}


Appendix 2 


\section{Appendix 3 \\ Listing of References to NIST and NBS in the Code of Federal Regulations \\ (Aanstoos)}

\begin{tabular}{|c|c|c|}
\hline CFR & Score & Description/Comments \\
\hline 10 CFR 100 & NBS & Determination of exclusion area low population zone and population center distance. \\
\hline 10 CFR 34 & NBS & Performance requirements for industrial radiography equipment. \\
\hline 10 CFR 35 & NIST & Dosimetry equipment. \\
\hline 10 CFR 430 & NIST & Reference Sources. \\
\hline $10 \mathrm{CFR} 430$ & NIST & Appendix R -- Uniform Test Method for Measuring Average Lamp Efficacy (LE) and Color Rendering Index (CRI) \\
\hline 10 CFR 431 & NIST & Testing laboratories. \\
\hline 10 CFR 436 & NIST & Methodological assumptions. \\
\hline 10 CFR 50 & NBS & Contents of applications; technical information. \\
\hline 14 CFR 145 & NBS & Equipment and materials: Ratings other than limited ratings. \\
\hline 14 CFR 25 & NIST & APPENDIX F TO PART 25. \\
\hline 14 CFR 36 & NBS & APPENDIX H -- NOISE REQUIREMENTS FOR HELICOPTERS UNDER SUBPART H \\
\hline 15 CFR 10 & NIST & General. \\
\hline 15 CFR 10 & NIST & Appeals. \\
\hline 15 CFR 10 & NIST & Interpretations. \\
\hline 15 CFR 200 & NIST & Statutory functions. \\
\hline 15 CFR 200 & NIST & Measurement research. \\
\hline 15 CFR 200 & NIST & Types of calibration and test services. \\
\hline 15 CFR 200 & NIST & Consulting and advisory services. \\
\hline 15 CFR 200 & NIST & Standard reference materials. \\
\hline 15 CFR 200 & NIST & Standard reference data. \\
\hline 15 CFR 200 & NIST & Publications. \\
\hline 15 CFR 200 & NIST & WWV-WWVH-WWVB broadcasts. \\
\hline 15 CFR 200 & NIST & Request procedure. \\
\hline 15 CFR 200 & NIST & Shipping insurance and risk of loss. \\
\hline 15 CFR 200 & NIST & Priorities and time of completion. \\
\hline 15 CFR 200 & NIST & Witnessing of operations. \\
\hline 15 CFR 200 & NIST & Reports. \\
\hline
\end{tabular}

\section{Appendix 3}




\begin{tabular}{|c|c|c|}
\hline 15 CFR 23 & NBS & Definitions. \\
\hline 15 CFR 230 & NIST & Introduction. \\
\hline 15 CFR 256 & NIST & The Research Associate Program. \\
\hline 15 CFR 265 & NIST & Closing the site. \\
\hline 15 CFR 270 & NIST & Definitions used in this part. \\
\hline 15 CFR 270 & NIST & Scope. \\
\hline 15 CFR 270 & NIST & Evidence collected by investigation participants who are not NIST employees. \\
\hline 15 CFR 270 & NIST & Subpoenas. \\
\hline 15 CFR 270 & NIST & Public hearings. \\
\hline 15 CFR 270 & NIST & Moving and preserving evidence. \\
\hline 15 CFR 270 & NIST & Information created by investigation participants who are not NIST employees. \\
\hline 15 CFR 270 & NIST & Freedom of Information Act. \\
\hline 15 CFR 270 & NIST & Protection of voluntarily submitted information. \\
\hline 15 CFR 270 & NIST & Public safety information. \\
\hline 15 CFR 280 & NIST & Description of rule/Delegation of authority. \\
\hline 15 CFR 280 & NIST & Definitions used in this subpart. \\
\hline 15 CFR 280 & NIST & [This section was removed. See 65 FR 3979839801 June 28 2000.] \\
\hline 15 CFR 280 & NIST & [This section was removed. See 65 FR 3979839801 June 28 2000.] \\
\hline 15 CFR 280 & NIST & [This section was removed. See 65 FR 3979839801 June 28 2000.] \\
\hline 15 CFR 280 & NIST & [This section was removed. See 65 FR 3979839801 June 28 2000.] \\
\hline 15 CFR 280 & NIST & [This section was removed. See 65 FR 3979839801 June 28 2000.] \\
\hline 15 CFR 280 & NIST & [This section was removed. See 65 FR 3979839801 June 28 2000.] \\
\hline 15 CFR 280 & NIST & [This section was removed. See 65 FR 3979839801 June 28 2000.] \\
\hline 15 CFR 280 & NIST & [This section was removed. See 65 FR 3979839801 June 28 2000.] \\
\hline 15 CFR 280 & NIST & [This section was removed. See 65 FR 3979839801 June 28 2000.] \\
\hline 15 CFR 280 & NIST & [This section was removed. See 65 FR 3979839801 June 28 2000.] \\
\hline 15 CFR 280 & NIST & [This section was removed. See 65 FR 3979839801 June 28 2000.] \\
\hline 15 CFR 280 & NIST & [This section was removed. See 65 FR 3979839801 June 28 2000.] \\
\hline 15 CFR 280 & NIST & [This section was removed. See 65 FR 3979839801 June 28 2000.] \\
\hline 15 CFR 280 & NIST & [This section was removed. See 65 FR 3979839801 June 28 2000.] \\
\hline 15 CFR 280 & NIST & \\
\hline 15 CFR 280 & NIST & Petitions for Approval of Documents. \\
\hline
\end{tabular}

\section{Appendix 3}




\begin{tabular}{|c|c|c|}
\hline 15 CFR 280 & NIST & Affirmations. \\
\hline 15 CFR 280 & NIST & Laboratory accreditation. \\
\hline 15 CFR 280 & NIST & [This section was removed. See 65 FR 3979839802 June 28 2000.] \\
\hline 15 CFR 280 & NIST & Scope. \\
\hline 15 CFR 280 & NIST & Violations. \\
\hline 15 CFR 280 & NIST & Penalties \\
\hline 15 CFR 280 & NIST & Administrative enforcement proceedings. \\
\hline 15 CFR 280 & NIST & Institution of administrative enforcement proceedings. \\
\hline 15 CFR 280 & NIST & Representation. \\
\hline 15 CFR 280 & NIST & Filing and service of papers other than charging letter. \\
\hline 15 CFR 280 & NIST & Answer and demand for hearing. \\
\hline 15 CFR 280 & NIST & Default. \\
\hline 15 CFR 280 & NIST & Summary decision. \\
\hline 15 CFR 280 & NIST & Discovery. \\
\hline 15 CFR 280 & NIST & Subpoenas. \\
\hline 15 CFR 280 & NIST & Matter protected against disclosure. \\
\hline 15 CFR 280 & NIST & Prehearing conference. \\
\hline 15 CFR 280 & NIST & Hearings. \\
\hline 15 CFR 280 & NIST & Interlocutory review of rulings. \\
\hline 15 CFR 280 & NIST & Proceeding without a hearing. \\
\hline 15 CFR 280 & NIST & Procedural stipulations; extension of time. \\
\hline 15 CFR 280 & NIST & Decision of the administrative law judge. \\
\hline 15 CFR 280 & NIST & Settlement. \\
\hline 15 CFR 280 & NIST & Reopening. \\
\hline 15 CFR 280 & NIST & Record for decision and availability of documents. \\
\hline 15 CFR 280 & NIST & Appeals. \\
\hline 15 CFR 280 & NIST & Recorded insignia required prior to offer for sale. \\
\hline 15 CFR 280 & NIST & [This section was removed. See 65 FR 3979839801 June 28 2000.] \\
\hline 15 CFR 280 & NIST & [This section was removed. See 65 FR 3979839801 June 28 2000.] \\
\hline 15 CFR 280 & NIST & [This section was removed. See 65 FR 3979839801 June 28 2000.] \\
\hline 15 CFR 280 & NIST & [This section was removed. See 65 FR 3979839801 June 28 2000.] \\
\hline 15 CFR 280 & NIST & [This section was removed. See 65 FR 3979839801 June 28 2000.] \\
\hline
\end{tabular}

\section{Appendix 3}




\begin{tabular}{|c|c|c|}
\hline 15 CFR 280 & NIST & [This section was removed. See 65 FR 3979839801 June 28 2000.] \\
\hline 15 CFR 280 & NIST & Application for insignia. \\
\hline 15 CFR 280 & NIST & Review of the application. \\
\hline 15 CFR 280 & NIST & Certificate of recordal. \\
\hline 15 CFR 280 & NIST & Recordal of additional insignia. \\
\hline 15 CFR 280 & NIST & Maintenance of the certificate of recordal. \\
\hline 15 CFR 280 & NIST & Notification of changes of address. \\
\hline 15 CFR 280 & NIST & Transfer or amendment of the certificate of recordal. \\
\hline 15 CFR 280 & NIST & Transfer or assignment of the trademark registration or recorded insignia. \\
\hline 15 CFR 280 & NIST & Change in status of trademark registration or amendment of the trademark. \\
\hline 15 CFR 280 & NIST & Cumulative listing of recordal information. \\
\hline 15 CFR 280 & NIST & Records and files of the United States Patent and Trademark Office \\
\hline 15 CFR 280 & NIST & [SUBPART E WAS REMOVED. SEE 65 FR 3979839801 JUNE 28 2000.] \\
\hline 15 CFR 280 & NIST & [This section was removed. See 65 FR 39798 June 28 2000.] \\
\hline 15 CFR 280 & NIST & [This section was removed. See 65 FR 39798 June 28 2000.] \\
\hline 15 CFR 280 & NIST & [SUBPART F WAS REMOVED. SEE 65 FR 3979839801 JUNE 28 2000.] \\
\hline 15 CFR 280 & NIST & [This section was removed. See 65 FR 3979839801 June 28 2000.] \\
\hline 15 CFR 280 & NIST & [This section was removed. See 65 FR 3979839801 June 28 2000.] \\
\hline 15 CFR 280 & NIST & [This section was removed. See 65 FR 3979839801 June 28 2000.] \\
\hline 15 CFR 280 & NIST & [This section was removed. See 65 FR 3979839801 June 28 2000.] \\
\hline 15 CFR 280 & NIST & [This section was removed. See 65 FR 3979839801 June 28 2000.] \\
\hline 15 CFR 280 & NIST & [SUBPART G WAS REDESIGNATED AS SUBPART C. SEE 65 FR 3979839802 JUNE 28 2000.] \\
\hline 15 CFR 280 & NIST & [This section was redesignated as $\S 280.200$. See 65 FR 3979839802 June 28 2000.] \\
\hline 15 CFR 280 & NIST & [This section was redesignated as $\S 280.2$. See 65 FR 3979839801 June 28 2000.] \\
\hline 15 CFR 280 & NIST & [This section was redesignated as $\S 280.201$. See 65 FR 3979839802 June 28 2000.] \\
\hline 15 CFR 280 & NIST & [This section was redesignated as $\S 280.202$. See 65 FR 3979839802 June 28 2000.] \\
\hline 15 CFR 280 & NIST & [This section was redesignated as $\S 280.203$. See 65 FR 3979839802 June 28 2000.] \\
\hline 15 CFR 280 & NIST & [This section was redesignated as $\S 280.204$. See 65 FR 3979839802 June 28 2000.] \\
\hline 15 CFR 280 & NIST & [This section was redesignated as $\S 280.205$. See 65 FR 3979839802 June 28 2000.] \\
\hline 15 CFR 280 & NIST & [This section was redesignated as $\S 280.206$. See 65 FR 3979839802 June 28 2000.] \\
\hline 15 CFR 280 & NIST & [This section was redesignated as $\S 280.207$. See 65 FR 3979839802 June 28 2000.] \\
\hline 15 CFR 280 & NIST & [This section was redesignated as $\S 280.208$. See 65 FR 3979839802 June 28 2000.] \\
\hline
\end{tabular}

\section{Appendix 3}




\begin{tabular}{|c|c|c|}
\hline 15 CFR 280 & NIST & [This section was redesignated as $\S 280.209$. See 65 FR 3979839802 June 28 2000.] \\
\hline 15 CFR 280 & NIST & [This section was redesignated as $\S 280.210$. See 65 FR 3979839802 June 28 2000.] \\
\hline 15 CFR 280 & NIST & [This section was redesignated as $\S 280.211$. See 65 FR 3979839802 June 28 2000.] \\
\hline 15 CFR 280 & NIST & [This section was redesignated as $\S 280.212$. See 65 FR 3979839802 June 28 2000.] \\
\hline 15 CFR 280 & NIST & [This section was redesignated as $\S 280.213$. See 65 FR 3979839802 June 28 2000.] \\
\hline 15 CFR 280 & NIST & [This section was redesignated as $\S 280.214$. See 65 FR 3979839802 June 28 2000.] \\
\hline 15 CFR 280 & NIST & [This section was redesignated as $\S 280.215$. See 65 FR 3979839802 June 28 2000.] \\
\hline 15 CFR 280 & NIST & [This section was redesignated as $\S 280.216$. See 65 FR 3979839802 June 28 2000.] \\
\hline 15 CFR 280 & NIST & [This section was redesignated as $\S 280.217$. See 65 FR 3979839802 June 28 2000.] \\
\hline 15 CFR 280 & NIST & [This section was redesignated as $\S 280.218$. See 65 FR 3979839802 June 28 2000.] \\
\hline 15 CFR 280 & NIST & [This section was redesignated as $\S 280.219$. See 65 FR 3979839802 June 28 2000.] \\
\hline 15 CFR 280 & NIST & [This section was redesignated as $\S 280.220$. See 65 FR 3979839802 June 28 2000.] \\
\hline 15 CFR 280 & NIST & [This section was redesignated as $\S 280.221$. See 65 FR 3979839802 June 28 2000.] \\
\hline 15 CFR 280 & NIST & [This section was redesignated as $\S 280.222$. See 65 FR 3979839802 June 28 2000.] \\
\hline 15 CFR 280 & NIST & [SUBPART H WAS REDESIGNATED AS SUBPART D. SEE 65 FR 3979839803 JUNE 28 2000.] \\
\hline 15 CFR 280 & NIST & [This section was redesignated as $\S 280.300$. See 65 FR 3979839803 June 28 2000.] \\
\hline 15 CFR 280 & NIST & [This section was redesignated as $\S 280.310$. See 65 FR 3979839803 June 28 2000.] \\
\hline 15 CFR 280 & NIST & [This section was redesignated as $\S 280.311$. See 65 FR 3979839803 June 28 2000.] \\
\hline 15 CFR 280 & NIST & [This section was redesignated as $\S 280.312$. See 65 FR 3979839803 June 28 2000.] \\
\hline 15 CFR 280 & NIST & [This section was redesignated as $\S 280.313$. See 65 FR 3979839803 June 28 2000.] \\
\hline 15 CFR 280 & NIST & [This section was redesignated as $\S 280.320$. See 65 FR 3979839803 June 28 2000.] \\
\hline 15 CFR 280 & NIST & [This section was redesignated as $\S 280.321$. See 65 FR 3979839803 June 28 2000.] \\
\hline 15 CFR 280 & NIST & [This section was redesignated as $\S 280.322$. See 65 FR 3979839803 June 28 2000.] \\
\hline 15 CFR 280 & NIST & [This section was redesignated as $\S 280.323$. See 65 FR 3979839803 June 28 2000.] \\
\hline 15 CFR 280 & NIST & [This section was redesignated as $\S 280.324$. See 65 FR 3979839803 June 28 2000.] \\
\hline 15 CFR 280 & NIST & [This section was redesignated as $\S 280.325$. See 65 FR 3979839803 June 28 2000.] \\
\hline 15 CFR 280 & NIST & [This section was redesignated as $\S 280.326$. See 65 FR 3979839803 June 28 2000.] \\
\hline 15 CFR 280 & NIST & [SUBPART I WAS REMOVED. SEE 65 FR 3979839801 JUNE 28 2000.] \\
\hline 15 CFR 280 & NIST & [This section was removed. See 65 FR 3979839801 June 28 2000.] \\
\hline 15 CFR 280 & NIST & [This section was removed. See 65 FR 3979839801 June 28 2000.] \\
\hline 15 CFR 280 & NIST & [This section was removed. See 65 FR 3979839801 June 28 2000.] \\
\hline 15 CFR 280 & NIST & [This section was removed. See 65 FR 3979839801 June 28 2000.] \\
\hline
\end{tabular}

\section{Appendix 3}




\begin{tabular}{|c|c|c|}
\hline 15 CFR 280 & NIST & [This section was removed. See 65 FR 3979839801 June 28 2000.] \\
\hline 15 CFR 280 & NIST & [This section was removed. See 65 FR 3979839801 June 28 2000.] \\
\hline 15 CFR 280 & NIST & [This section was removed. See 65 FR 3979839801 June 28 2000.] \\
\hline 15 CFR 280 & NIST & [This section was removed. See 65 FR 3979839801 June 28 2000.] \\
\hline 15 CFR 280 & NIST & [This section was removed. See 65 FR 3979839801 June 28 2000.] \\
\hline 15 CFR 280 & NIST & [This section was removed. See 65 FR 3979839801 June 28 2000.] \\
\hline 15 CFR 280 & NIST & [This section was removed. See 65 FR 3979839801 June 28 2000.] \\
\hline 15 CFR 280 & NIST & [This section was removed. See 65 FR 3979839801 June 28 2000.] \\
\hline 15 CFR 280 & NIST & [This section was removed. See 65 FR 3979839801 June 28 2000.] \\
\hline 15 CFR 280 & NIST & [SUBPART J WAS REMOVED. SEE 65 FR 3979839801 JUNE 28 2000.] \\
\hline 15 CFR 280 & NIST & [This section was removed. See 65 FR 3979839801 JUNE 28 2000.] \\
\hline 15 CFR 280 & NIST & [This section was removed. See 65 FR 3979839801 JUNE 28 2000.] \\
\hline 15 CFR 280 & NIST & [SUBPART K WAS REMOVED. SEE 65 FR 3979839801 JUNE 28 2000.] \\
\hline 15 CFR 280 & NIST & [This section was removed. See 65 FR 3979839801 JUNE 28 2000.] \\
\hline 15 CFR 280 & NIST & [This section was removed. See 65 FR 3979839801 JUNE 28 2000.] \\
\hline 15 CFR 280 & NIST & [This section was removed. See 65 FR 3979839801 JUNE 28 2000.] \\
\hline 15 CFR 280 & NIST & [This section was removed. See 65 FR 3979839801 JUNE 28 2000.] \\
\hline 15 CFR 280 & NIST & [This section was removed. See 65 FR 3979839801 JUNE 28 2000.] \\
\hline 15 CFR 280 & NIST & [This section was removed. See 65 FR 3979839801 JUNE 28 2000.] \\
\hline 15 CFR 280 & NIST & [This section was removed. See 65 FR 3979839801 JUNE 28 2000.] \\
\hline 15 CFR 280 & NIST & [This section was removed. See 65 FR 3979839801 JUNE 28 2000.] \\
\hline 15 CFR 280 & NIST & [This section was removed. See 65 FR 3979839801 JUNE 28 2000.] \\
\hline 15 CFR 280 & NIST & [This section was removed. See 65 FR 3979839801 JUNE 28 2000.] \\
\hline 15 CFR 280 & NIST & [This section was removed. See 65 FR 3979839801 JUNE 28 2000.] \\
\hline 15 CFR 280 & NIST & [This section was removed. See 65 FR 3979839801 JUNE 28 2000.] \\
\hline 15 CFR 280 & NIST & [This section was removed. See 65 FR 3979839801 JUNE 28 2000.] \\
\hline 15 CFR 280 & NIST & [This section was removed. See 65 FR 3979839801 JUNE 28 2000.] \\
\hline 15 CFR 280 & NIST & [SUBPART L WAS REMOVED. SEE 65 FR 3979839801 JUNE 28 2000.] \\
\hline 15 CFR 280 & NIST & [This section was removed. See 65 FR 3979839801 JUNE 28 2000.] \\
\hline 15 CFR 280 & NIST & [This section was removed. See 65 FR 3979839801 JUNE 28 2000.] \\
\hline 15 CFR 280 & NIST & [This section was removed. See 65 FR 3979839801 JUNE 28 2000.] \\
\hline 15 CFR 280 & NIST & [This section was removed. See 65 FR 3979839801 JUNE 28 2000.] \\
\hline
\end{tabular}

\section{Appendix 3}




\begin{tabular}{|c|c|c|}
\hline 15 CFR 280 & NIST & [This section was removed. See 65 FR 3979839801 JUNE 28 2000.] \\
\hline 15 CFR 280 & NIST & [This section was removed. See 65 FR 3979839801 JUNE 28 2000.] \\
\hline 15 CFR 280 & NIST & [This section was removed. See 65 FR 3979839801 JUNE 28 2000.] \\
\hline 15 CFR 280 & NIST & [This section was removed. See 65 FR 3979839801 JUNE 28 2000.] \\
\hline 15 CFR 280 & NIST & [This section was removed. See 65 FR 3979839801 JUNE 28 2000.] \\
\hline 15 CFR 280 & NIST & [This section was removed. See 65 FR 3979839801 JUNE 28 2000.] \\
\hline 15 CFR 280 & NIST & [This section was removed. See 65 FR 3979839801 JUNE 28 2000.] \\
\hline 15 CFR 280 & NIST & [This section was removed. See 65 FR 3979839801 JUNE 28 2000.] \\
\hline 15 CFR 280 & NIST & [This section was removed. See 65 FR 3979839801 JUNE 28 2000.] \\
\hline 15 CFR 280 & NIST & [This section was removed. See 65 FR 3979839801 JUNE 28 2000.] \\
\hline 15 CFR 285 & NIST & Purpose. \\
\hline 15 CFR 285 & NIST & Confidentiality. \\
\hline 15 CFR 285 & NIST & Referencing NVLAP accreditation. \\
\hline 15 CFR 285 & NIST & Establishment of laboratory accreditation programs (LAPs) within NVLAP. \\
\hline 15 CFR 285 & NIST & Termination of a LAP. \\
\hline 15 CFR 285 & NIST & Application for accreditation. \\
\hline 15 CFR 285 & NIST & Assessment. \\
\hline 15 CFR 285 & NIST & Proficiency testing. \\
\hline 15 CFR 285 & NIST & Granting accreditation. \\
\hline 15 CFR 285 & NIST & Renewal of accreditation. \\
\hline 15 CFR 285 & NIST & Changes to scope of accreditation. \\
\hline 15 CFR 285 & NIST & Monitoring visits. \\
\hline 15 CFR 285 & NIST & Denial suspension revocation or termination of accreditation. \\
\hline 15 CFR 285 & NIST & Criteria for accreditation. \\
\hline 15 CFR 285 & NIST & Obtaining documents. \\
\hline 15 CFR 285 & NIST & [This section was removed. See 66 FR 2921929223 May 30 2001.] \\
\hline 15 CFR 285 & NIST & [This section was removed. See 66 FR 2921929223 May 30 2001.] \\
\hline 15 CFR 285 & NIST & [This section was removed. See 66 FR 2921929223 May 30 2001.] \\
\hline 15 CFR 285 & NIST & [This section was removed. See 66 FR 2921929223 May 30 2001.] \\
\hline 15 CFR 285 & NIST & [SUBPART C WAS REMOVED. SEE 66 FR 2921929223 MAY 30 2001.] \\
\hline 15 CFR 285 & NIST & [This section was removed. See 66 FR 2921929223 May 30 2001.] \\
\hline 15 CFR 285 & NIST & [This section was removed. See 66 FR 2921929223 May 30 2001.] \\
\hline
\end{tabular}

\section{Appendix 3}




\begin{tabular}{|c|c|c|}
\hline 15 CFR 285 & NIST & [This section was removed. See 66 FR 2921929223 May 30 2001.] \\
\hline 15 CFR 285 & NIST & [This section was removed. See 66 FR 2921929223 May 30 2001.] \\
\hline 15 CFR 285 & NIST & [This section was removed. See 66 FR 2921929223 May 30 2001.] \\
\hline 15 CFR 285 & NIST & [This section was removed. See 66 FR 2921929223 May 30 2001.] \\
\hline 15 CFR 285 & NIST & [SUBPART D WAS REMOVED. SEE 66 FR 2921929223 MAY 30 2001.] \\
\hline 15 CFR 285 & NIST & [This section was removed. See 66 FR 2921929223 MAY 30 2001.] \\
\hline 15 CFR 285 & NIST & [This section was removed. See 66 FR 2921929223 MAY 30 2001.] \\
\hline 15 CFR 285 & NIST & [This section was removed. See 66 FR 2921929223 MAY 30 2001.] \\
\hline 15 CFR 286 & NIST & Scope. \\
\hline 15 CFR 286 & NIST & Objective. \\
\hline 15 CFR 286 & NIST & Implementation. \\
\hline 15 CFR 286 & NIST & Program requirements. \\
\hline 15 CFR 286 & NIST & Public consultation. \\
\hline 15 CFR 286 & NIST & Evaluation process. \\
\hline 15 CFR 286 & NIST & Maintaining recognized status. \\
\hline 15 CFR 286 & NIST & Appeal. \\
\hline 15 CFR 286 & NIST & Listings. \\
\hline 15 CFR 286 & NIST & Terminations. \\
\hline 15 CFR 287 & NIST & Definitions. $\mathrm{n} 1$ \\
\hline 15 CFR 287 & NIST & Responsibilities of the National Institute of Standards and Technology. \\
\hline 15 CFR 287 & NIST & Responsibilities of Federal agencies. \\
\hline 15 CFR 287 & NIST & Responsibilities of an Agency Standards Executive. \\
\hline 15 CFR 290 & NIST & Definitions. \\
\hline 15 CFR 290 & NIST & Program description. \\
\hline 15 CFR 290 & NIST & Terms and schedule of financial assistance. \\
\hline 15 CFR 290 & NIST & Basic proposal qualifications. \\
\hline 15 CFR 290 & NIST & Proposal evaluation and selection criteria. \\
\hline 15 CFR 290 & NIST & Proposal selection process. \\
\hline 15 CFR 290 & NIST & Reviews of centers. \\
\hline 15 CFR 291 & NIST & Program description. \\
\hline 15 CFR 291 & NIST & Environmental integration projects. \\
\hline 15 CFR 291 & NIST & Environmental tools and techniques projects. \\
\hline
\end{tabular}

\section{Appendix 3}




\begin{tabular}{|c|c|c|}
\hline 15 CFR 291 & NIST & National industry-specific pollution prevention and environmental compliance resource centers. \\
\hline 15 CFR 291 & NIST & Proposal selection process. \\
\hline 15 CFR 292 & NIST & Program description. \\
\hline 15 CFR 292 & NIST & Training development and deployment projects. \\
\hline 15 CFR 292 & NIST & Technical tools techniques practices and analyses projects. \\
\hline 15 CFR 292 & NIST & Proposal selection process. \\
\hline 15 CFR 295 & NIST & Definitions. \\
\hline 15 CFR 295 & NIST & The selection process. \\
\hline 15 CFR 295 & NIST & Use of pre-proposals in the selection process. \\
\hline 15 CFR 295 & NIST & Intellectual property rights; Publication of research results. \\
\hline 15 CFR 295 & NIST & Qualification of proposers. \\
\hline 15 CFR 4 & NIST & Appendix B to Part 4 -- Officials Authorized to Deny Requests for Records... \\
\hline 15 CFR 8 & NBS & APPENDIX A -- PROGRAMS COVERED BY TITLE VI \\
\hline 16 CFR 1209 & NBS & Procedure for calibration of radiation instrumentation. \\
\hline 16 CFR 1303 & NBS & Findings. \\
\hline 16 CFR 1512 & NBS & Mechanical requirements. \\
\hline 16 CFR 200 & NIST & Use of results or reports. \\
\hline 16 CFR 230 & NIST & Description of services and list of fees incorporation by reference. \\
\hline 16 CFR 256 & NIST & Procedure. \\
\hline 16 CFR 265 & NIST & Photography for advertising or commercial purposes; advertising and soliciting. \\
\hline 16 CFR 311 & NIST & Testing. \\
\hline 16 CFR 311 & NIST & Labeling. \\
\hline 16 CFR 311 & NIST & Prohibited acts. \\
\hline 17 CFR 200 & NIST & Fees and bills. \\
\hline 17 CFR 256 & NIST & Qualifications. \\
\hline 18 CFR 153 & NBS & Definitions. \\
\hline 18 CFR 200 & NIST & Description of services and list of fees incorporation by reference. \\
\hline 18 CFR 256 & NIST & Duration of projects. \\
\hline 18 CFR 3B & NBS & Safeguarding information in manual and computer-based record systems. \\
\hline $21 \mathrm{CFR} 1$ & NBS & Exemptions from required label statements. \\
\hline 21 CFR 172 & NBS & FILMS AND RELATED SUBSTANCES \\
\hline 21 CFR 172 & NBS & Synthetic fatty alcohols. \\
\hline
\end{tabular}

\section{Appendix 3}




\begin{tabular}{|c|c|c|}
\hline 21 CFR 172 & NBS & Petroleum wax. \\
\hline 21 CFR 173 & NBS & Combustion product gas. \\
\hline 21 CFR 178 & NBS & Mineral oil. \\
\hline 21 CFR 178 & NBS & Polyhydric alcohol esters of oxidatively refined (Gersthofen process) montan wax acids. \\
\hline 21 CFR 178 & NBS & Surface lubricants used in the manufacture of metallic articles. \\
\hline 21 CFR 501 & NBS & Labeling of animal food with number of servings. \\
\hline 21 CFR 874 & NBS & Audiometer calibration set. \\
\hline 21 CFR 900 & NIST & Definitions. \\
\hline 22 CFR 1101 & NBS & Security confidentiality and protection of records. \\
\hline 24 CFR 200 & NBS & Administrator qualifications and procedures for HUD building products certification programs. \\
\hline 24 CFR 200 & NBS & \\
\hline 24 CFR 200 & NBS & Supplementary specific requirements under the HUD Building Products Standards and Certification Program \\
\hline 24 CFR 200 & NIST & Supplementary specific requirements under the HUD building product standards and certification program... \\
\hline 24 CFR 3280 & NIST & Materials. \\
\hline 25 CFR 141 & NBS & Health and sanitation requirements. \\
\hline 25 CFR 43 & NBS & Assuring integrity of records. \\
\hline 25 CFR 700 & NBS & Assuring integrity of records. \\
\hline 28 CFR 700 & NBS & Security of systems of records. \\
\hline 29 CFR 1910 & NBS & Occupational noise exposure. \\
\hline 29 CFR 1910 & NBS & Specifications for accident prevention signs and tags. \\
\hline 29 CFR 1910 & NIST & Asbestos. \\
\hline 29 CFR 1910 & NIST & Cadmium. (PART I OF II) \\
\hline 29 CFR 1910 & NBS & APPENDIX C -- FIRE PROTECTION REFERENCES FOR FURTHER INFORMATION \\
\hline 29 CFR 1915 & NIST & Asbestos. \\
\hline 29 CFR 1915 & NIST & Polarized Light Microscopy of Asbestos-Non-Mandatory \\
\hline 29 CFR 1915 & NIST & Appendix F to $\S 1915.1027$-- Nonmandatory Protocol for Biological Monitoring. \\
\hline 29 CFR 1919 & NBS & General duties; exemptions. \\
\hline 29 CFR 1919 & NBS & General duties exemptions. \\
\hline 29 CFR 1926 & NIST & Asbestos. \\
\hline 29 CFR 1926 & NIST & Polarized Light Microscopy of Asbestos (Non-Mandatory) \\
\hline 29 CFR 1926 & NBS & APPENDIX A -- SOIL CLASSIFICATION \\
\hline 29 CFR 1926 & NBS & APPENDIX C -- TIMBER SHORING FOR TRENCHES \\
\hline
\end{tabular}

\section{Appendix 3}




\begin{tabular}{|c|c|c|}
\hline 29 CFR 570 & NBS & Exposure to radioactive substances and to ionizing radiations (Order 6). \\
\hline 30 CFR 56 & NBS & Guy wires. \\
\hline 30 CFR 57 & NBS & Guy wires. \\
\hline 30 CFR 7 & NBS & Product testing. \\
\hline 30 CFR 7 & NBS & Quality assurance. \\
\hline 30 CFR 7 & NIST & Test equipment and specifications. \\
\hline 30 CFR 75 & NBS & Methods of measurement; light measuring instruments. \\
\hline 31 CFR 1 & NBS & Requirements relating to systems of records. \\
\hline 32 CFR 650 & NBS & Radioactive materials and nuclear accidents and incidents. \\
\hline 33 CFR 126 & NBS & Conditions for designation as designated waterfront facility. \\
\hline 40 CFR 1065 & NIST & Dynamometer and engine equipment specifications. \\
\hline 40 CFR 1065 & NIST & Flow meters. \\
\hline 40 CFR 1065 & NIST & Analytical gases. \\
\hline 40 CFR 1065 & NIST & International calibration standards. \\
\hline 40 CFR 1065 & NIST & Torque calibration. \\
\hline 40 CFR 1065 & NIST & Definitions. \\
\hline 40 CFR 1065 & NIST & Symbols acronyms and abbreviations. \\
\hline 40 CFR 136 & NBS & APPENDIX A -- METHODS FOR ORGANIC CHEMICAL ANALYSIS OF WASTEWATER [PART 1 OF 3] \\
\hline 40 CFR 136 & NBS & APPENDIX A -- METHODS FOR ORGANIC CHEMICAL ANALYSIS OF WASTEWATER [PART 2 OF 3] \\
\hline 40 CFR 136 & NIST & APPENDIX A TO PART 136 -- METHODS FOR ORGANIC CHEMICAL ANALYSIS OF WASTEWATER [PART 3 OF 3] \\
\hline 40 CFR 141 & NBS & Definitions. \\
\hline 40 CFR 141 & NBS & [This section was removed effective Dec. 8 2003. See 65 FR 7670876745 Dec. 7 2000.] \\
\hline 40 CFR 141 & NBS & Maximum contaminant levels for radionuclides. [Effective Dec. 8 2003.] \\
\hline 40 CFR 430 & NIST & NON-WOVEN AND PAPERBOARD FROM PURCHASED PULP SUBCATEGORY GENERAL PROVISIONS APPENDIX A \\
\hline 40 CFR 435 & NIST & Appendix 5 to Subpart A of Part 435 -- Determination of Crude Oil Contamination in Non-Aqueous Drilling Fluids... \\
\hline 40 CFR 435 & NIST & Appendix 6 to Subpart A of Part 435 -- Reverse Phase Extraction (RPE) Method for Detection of Oil Contamination... \\
\hline 40 CFR 50 & NBS & Definitions. \\
\hline 40 CFR 50 & NIST & Appendix M to Part 50 -- Reference Method for the Determination of Particulate Matter \\
\hline 40 CFR 50 & NBS & APPENDIX A -- REFERENCE METHOD FOR THE DETERMINATION OF SULFUR DIOXIDE IN THE ATMOSPHERE \\
\hline 40 CFR 50 & NBS & APPENDIX B -- REFERENCE METHOD FOR THE DETERMINTION OF PARTICULATE MATTER IN THE ATMOSPHERE \\
\hline 40 CFR 50 & NBS & APPENDIX C -- MEASUREMENT AND CALIBRATION PROCEDURE FOR THE MEASUREMENT OF CARBON MONOXIDE \\
\hline 40 CFR 50 & NBS & APPENDIX D -- MEASUREMENT AND CALIBRATION PROCEDURE FOR THE MEASUREMENT OF OZONE \\
\hline
\end{tabular}

\section{Appendix 3}




\begin{tabular}{|c|c|c|}
\hline 40 CFR 50 & NBS & $\begin{array}{l}\text { APPENDIX F -- MEASUREMENT PRINCIPLE AND CALIBRATION PROCEDURE FOR THE MEASUREMENT OF NITROGEN } \\
\text { DIOXIDE }\end{array}$ \\
\hline 40 CFR 50 & NBS & APPENDIX J -- REFERENCE METHOD FOR THE DETERMINATION OF PARTICULATE MATTER IN THE ATMOSHPERE \\
\hline 40 CFR 50 & NIST & APPENDIX L TO PART 50 -- REFERANCE METHOD FOR THE DETERMINATION OF FINE PARTICULATE MATTER \\
\hline 40 CFR 51 & NIST & APPENDIX M TO PART 51 -- RECOMMENDED TEST METHODS FOR STATE IMPLEMENTATION PLANS \\
\hline 40 CFR 51 & NBS & APPENDIX P -- MINIMUM EMISSION MONITORING REQUIREMENTS \\
\hline 40 CFR 51 & NIST & APPENDIX A TO SUBPART S -- CALIBRATIONS \\
\hline 40 CFR 52 & NIST & Control strategy: Ozone control measures for Cook DuPage Kane Lake McHenry and Will Counties. \\
\hline 40 CFR 53 & NBS & Generation of test atmospheres. \\
\hline 40 CFR 53 & NIST & Applications for reference or equivalent method determinations. \\
\hline 40 CFR 53 & NIST & Demonstration of compliance with design specifications and manufacturing and test requirements. \\
\hline 40 CFR 53 & NIST & Leak check test. \\
\hline 40 CFR 53 & NIST & Test for flow rate accuracy regulation measurement accuracy and cut-off. \\
\hline 40 CFR 53 & NIST & Test for proper sampler operation following power interruptions. \\
\hline 40 CFR 53 & NIST & Test for effect of variations in power line voltage and ambient temperature. \\
\hline 40 CFR 53 & NIST & Test for effect of variations in ambient pressure \\
\hline 40 CFR 53 & NIST & Test for filter temperature control during sampling and post-sampling periods. \\
\hline 40 CFR 53 & NIST & Aerosol transport test for Class I equivalent method samplers. \\
\hline 40 CFR 53 & NIST & Test procedure: Full wind tunnel test. \\
\hline 40 CFR 58 & NIST & Definitions. \\
\hline 40 CFR 58 & NIST & APPENDIX A -- QUALITY ASSURANCE REQUIREMENTS FOR SLAMS \\
\hline 40 CFR 58 & NIST & APPENDIX B -- QUALITY ASSURANCE REQUIREMENTS FOR PSD AIR MONITORING \\
\hline 40 CFR 58 & NBS & $\begin{array}{l}\text { APPENDIX B -- QUALITY ASSURANCE REQUIREMENTS FOR PREVENTION OF SIGNIFICANT DETERIORATION AIR } \\
\text { MONITORING }\end{array}$ \\
\hline 40 CFR 60 & NBS & TABLES TO SUBPART DDDD APPENDIX B -- PERFORMANCE SPECIFICATIONS \\
\hline 40 CFR 60 & NIST & APPENDIX B -- PERFORMANCE SPECIFICATIONS \\
\hline 40 CFR 60 & NBS & TABLES TO SUBPART DDDD APPENDIX F -- QUALITY ASSURANCE PROCEDURES \\
\hline 40 CFR 63 & NIST & Monitoring requirements. \\
\hline 40 CFR 63 & NIST & Monitoring requirements. \\
\hline 40 CFR 63 & NIST & Quality Assurance Procedures for Continuous Emissions Monitors Used for Hazardous Waste Combustors \\
\hline 40 CFR 63 & NIST & What are my monitoring installation operation and maintenance requirements? \\
\hline 40 CFR 63 & NIST & What are my monitoring system installation operation and maintenance requirements? \\
\hline 40 CFR 63 & NIST & APPENDIX A -- TEST METHODS (I OF II) \\
\hline
\end{tabular}

\section{Appendix 3}




\begin{tabular}{|c|c|c|}
\hline 40 CFR 63 & NIST & APPENDIX A -- TEST METHODS (II OF II) \\
\hline 40 CFR 63 & NBS & TABLES TO SUBPART SSSSS OF PART 63 APPENDIX A -- TEST METHODS (I OF II) \\
\hline 40 CFR 72 & NIST & Definitions. \\
\hline 40 CFR 72 & NIST & Measurements abbreviations and acronyms. \\
\hline 40 CFR 75 & NIST & Certification quality assurance and quality control record provisions. \\
\hline 40 CFR 75 & NIST & Petitions to the Administrator. \\
\hline 40 CFR 75 & NIST & APPENDIX A TO PART 75 -- SPECIFICATIONS AND TEST PROCEDURES \\
\hline 40 CFR 75 & NIST & APPENDIX D TO PART 75 -- OPTIONAL SO[2] EMISSIONS DATA PROTOCOL FOR GAS-FIRED AND OIL-FIRED UNITS \\
\hline 40 CFR 763 & NBS & Analysis. \\
\hline 40 CFR 763 & NBS & Response actions. \\
\hline 40 CFR 763 & NIST & APPENDIX C TO SUBPART E - ASBESTOS MODEL ACCREDITATION PLAN \\
\hline 40 CFR 763 & NBS & APPENDIX A -- INTERIM TRANSMISSION ELECTRON MICROSCOPY ANALYTICAL METHODS \\
\hline 40 CFR 763 & NBS & APPENDIX E -- INTERIM METHOD OF THE DETERMINATION OF ASBESTOS IN BULK INSULATION SAMPLES \\
\hline 40 CFR 799 & NBS & TSCA partition coefficient (n -octanol/water) generator column method. \\
\hline 40 CFR 799 & NBS & TSCA water solubility: Generator column method. \\
\hline 40 CFR 80 & NBS & APPENDIX B -- TEST METHODS FOR LEAD IN GASOLINE \\
\hline 40 CFR 85 & NBS & Calibrations adjustments -- EPA 81. \\
\hline 40 CFR 85 & NIST & Steady state test equipment calibrations adjustments and quality control -- EPA 91. \\
\hline 40 CFR 86 & NBS & Analytical gases. \\
\hline 40 CFR 86 & NBS & Analytical gases. \\
\hline 40 CFR 86 & NBS & Gas meter or flow instrumentation calibration; particulate methanol and formaldehyde measurement. \\
\hline 40 CFR 86 & NBS & Gas specifications. \\
\hline 40 CFR 86 & NBS & Dynamometer and engine equipment specifications. \\
\hline 40 CFR 86 & NBS & Dynamometer calibration. \\
\hline 40 CFR 86 & NBS & Humidity calculations. \\
\hline 40 CFR 86 & NBS & Analytical gases. \\
\hline 40 CFR 86 & NBS & Instrument checks. \\
\hline 40 CFR 86 & NBS & Analytical gases. \\
\hline 40 CFR 86 & NBS & Dynamometer and engine equipment specifications. \\
\hline 40 CFR 86 & NBS & Analytical gases. \\
\hline 40 CFR 86 & NBS & Analytical gases. \\
\hline 40 CFR 86 & NBS & CVS calibration. \\
\hline
\end{tabular}

\section{Appendix 3}




\begin{tabular}{|c|c|c|}
\hline 40 CFR 86 & NBS & CVS calibration. \\
\hline 40 CFR 86 & NBS & Gas meter or flow instrumentation calibration; particulate methanol and formaldehyde measurement. \\
\hline 40 CFR 86 & NIST & Analytical gases. \\
\hline 40 CFR 86 & NIST & Hydrocarbon analyzer calibration. \\
\hline 40 CFR 86 & NIST & Analytical gases. \\
\hline 40 CFR 86 & NIST & Hydrocarbon analyzer calibration. \\
\hline 40 CFR 86 & NIST & Analytical gases. \\
\hline 40 CFR 86 & NIST & Hydrocarbon analyzer calibration. \\
\hline 40 CFR 86 & NIST & Equipment required and specifications; overview. \\
\hline 40 CFR 86 & NIST & Filter stabilization and microbalance workstation environmental conditions microbalance specifications... \\
\hline 40 CFR 86 & NIST & Analytical gases. \\
\hline 40 CFR 86 & NIST & CVS calibration. \\
\hline 40 CFR 86 & NIST & Hydrocarbon analyzer calibration. \\
\hline 40 CFR 89 & NIST & Acronyms and abbreviations. \\
\hline 40 CFR 89 & NIST & Dynamometer specifications and calibration weights. \\
\hline 40 CFR 89 & NIST & Analytical gases. \\
\hline 40 CFR 89 & NIST & Appendix A to Subpart D -- Tables \\
\hline 40 CFR 89 & NIST & Dilute sampling procedures -- CVS calibration. \\
\hline 40 CFR 90 & NIST & Acronyms and abbreviations. \\
\hline 40 CFR 90 & NIST & Dynamometer specifications and calibration accuracy. \\
\hline 40 CFR 90 & NIST & Analytical gases. \\
\hline 40 CFR 90 & NIST & Analyzer accuracy and specifications. \\
\hline 40 CFR 90 & NIST & Dilute sampling procedures -- CVS calibration. \\
\hline 40 CFR 91 & NIST & Acronyms and abbreviations. \\
\hline 40 CFR 91 & NIST & Dynamometer specifications and calibration accuracy. \\
\hline 40 CFR 91 & NIST & Analytical gases. \\
\hline 40 CFR 91 & NIST & Analyzer accuracy and specifications. \\
\hline 40 CFR 91 & NIST & Dilute sampling procedure -- CVS calibration. \\
\hline 40 CFR 92 & NIST & Definitions and abbreviations. \\
\hline 40 CFR 92 & NIST & Equipment for loading the engine. \\
\hline 40 CFR 92 & NIST & Analytical gases. \\
\hline 40 CFR 92 & NIST & Engine output measurement system calibrations. \\
\hline
\end{tabular}

\section{Appendix 3}




\begin{tabular}{|c|c|c|}
\hline 40 CFR 92 & NIST & Gas meter or flow instrumentation calibration particulate measurement. \\
\hline 40 CFR 92 & NIST & Smoke meter calibration. \\
\hline 40 CFR 92 & NIST & Emission measurement accuracy. \\
\hline 40 CFR 94 & NIST & Abbreviations. \\
\hline 40 CFR 94 & NIST & Test procedures for Category 3 marine engines. \\
\hline 41 CFR 101 & NIST & What registration services are available through GSA? \\
\hline 41 CFR 301 & NIST & May we use electronic signatures on travel documents? \\
\hline 41 CFR 301 & NIST & APPENDIX D TO CHAPTER 301 -- GLOSSARY OF ACRONYMS \\
\hline 43 CFR 2 & NBS & Assuring integrity of records. \\
\hline 45 CFR 303 & NBS & Provision of services in interstate IV-D cases. \\
\hline 45 CFR 303 & NBS & Requests for collection of past-due support by Federal tax refund offset. \\
\hline 46 CFR 160 & NBS & Incorporation by reference. \\
\hline 46 CFR 160 & NBS & Incorporation by reference. \\
\hline 46 CFR 160 & NBS & Incorporation by reference. \\
\hline 46 CFR 160 & NBS & Approval and production tests. \\
\hline 46 CFR 160 & NBS & Incorporation by reference. \\
\hline 46 CFR 160 & NBS & Incorporation by reference. \\
\hline 46 CFR 160 & NBS & Incorporation by reference. \\
\hline 46 CFR 160 & NBS & Approval and production tests. \\
\hline 46 CFR 160 & NBS & Applicable specification and publication. \\
\hline 46 CFR 160 & NBS & Type and size. \\
\hline 46 CFR 160 & NBS & Incorporation by reference. \\
\hline 46 CFR 160 & NBS & Approval and production tests. \\
\hline 46 CFR 160 & NBS & Incorporation by reference. \\
\hline 46 CFR 160 & NBS & Incorporation by reference. \\
\hline 46 CFR 160 & NBS & Design and performance of inflatable life rafts. \\
\hline 46 CFR 160 & NBS & Additional requirements for design and performance of SOLAS A and SOLAS B inflatable life rafts. \\
\hline 46 CFR 160 & NBS & Incorporation by reference. \\
\hline 46 CFR 160 & NBS & Construction. \\
\hline 46 CFR 160 & NBS & Incorporation by reference. \\
\hline 46 CFR 160 & NBS & Construction. \\
\hline 46 CFR 160 & NBS & Incorporation by reference. \\
\hline
\end{tabular}

\section{Appendix 3}




\begin{tabular}{|c|c|c|}
\hline 46 CFR 160 & NIST & Incorporation by reference. \\
\hline 46 CFR 162 & NBS & Requirements. \\
\hline 46 CFR 162 & NBS & Documents incorporated by reference. \\
\hline 46 CFR 162 & NBS & Designation of facilities. \\
\hline 46 CFR 164 & NBS & Inspection and testing. \\
\hline 46 CFR 164 & NBS & Procedure for approval. \\
\hline 46 CFR 164 & NBS & Testing procedure. \\
\hline 46 CFR 164 & NBS & Procedure for approval. \\
\hline 46 CFR 164 & NBS & Testing procedure. \\
\hline 46 CFR 164 & NBS & Procedure for approval. \\
\hline 46 CFR 164 & NBS & General. \\
\hline 46 CFR 169 & NBS & Incorporation by reference. \\
\hline 46 CFR 380 & NBS & Reproduction. \\
\hline 47 CFR 2 & NIST & Designation of Telecommunication Certification Bodies (TCBs). \\
\hline 47 CFR 2 & NIST & Requirements for Telecommunication Certification Bodies. \\
\hline 47 CFR 24 & NBS & Appendix I -- A Procedure for Calculating PCS Signal Levels at Microwave Receivers \\
\hline 47 CFR 68 & NIST & Designation of Telecommunication Certification Bodies (TCBs). \\
\hline 47 CFR 68 & NIST & Requirements for Telecommunication Certification Bodies. \\
\hline 47 CFR 73 & NBS & Rebroadcasts. \\
\hline 47 CFR 73 & NBS & Carrier frequency measurements. \\
\hline 47 CFR 90 & NBS & Frequencies available for use in the U.S./Mexico and U.S./Canada border areas. \\
\hline 48 CFR 908 & NBS & Calibration services. \\
\hline 49 CFR 171 & NBS & Reference material. \\
\hline 49 CFR 178 & NBS & Specification 3T seamless steel cylinder. \\
\hline 49 CFR 390 & NBS & Copies of records or documents. \\
\hline 49 CFR 395 & NBS & Automatic on-board recording devices. \\
\hline 49 CFR 571 & NBS & Standard No. 116; Motor vehicle brake fluids. \\
\hline 5 CFR 581 & NIST & APPENDIX A TO PART 581 -- LIST OF AGENTS DESIGNATED TO ACCEPT LEGAL PROCESS \\
\hline 5 CFR 293 & NBS & Special safeguards for automated records. \\
\hline 5 CFR 930 & NIST & Training requirement. \\
\hline 7 CFR 58 & NBS & Equipment and utensils. \\
\hline 7 CFR 801 & NIST & Design requirements incorporated by reference. \\
\hline
\end{tabular}

\section{Appendix 3}




\begin{tabular}{|l|l|l|} 
7 CFR 802 & NBS & Qualified laboratories. \\
\hline 7 CFR 802 & NIST & Applicability. [Effective until Sept. 8 2003.] \\
\hline 7 CFR 802 & NIST & Applicability. [Effective Sept. 8 2003.] \\
\hline 9 CFR 201 & NIST & Scales; accurate weights repairs adjustments or replacements after inspection. \\
\hline 9 CFR 317 & NBS & Definitions and procedures for determining net weight compliance. \\
\hline 9 CFR 317 & NIST & Definitions and procedures for determining net weight compliance. \\
\hline 9 CFR 317 & NIST & Scale requirements for accurate weights repairs adjustments and replacement after inspection. \\
\hline 9 CFR 317 & NIST & Scales: testing of. \\
\hline 9 CFR 381 & NBS & Quantity of contents. \\
\hline 9 CFR 381 & NBS & Definitions and procedures for determining net weight compliance. \\
\hline 9 CFR 381 & NIST & Definitions and procedures for determining net weight compliance. \\
\hline 9 CFR 381 & NIST & Scale requirements for accurate weights repairs adjustments and replacement after inspection. \\
\hline 9 CFR 381 & NIST & Scales; testing of. \\
\hline
\end{tabular}

\section{Appendix 3}




\section{Appendix 4}

References to NIST/NBS in the Code of Federal Regulations by title (Aanstoos)

\begin{tabular}{|c|c|c|c|c|c|}
\hline $\begin{array}{l}\text { CFR } \\
\text { Title }\end{array}$ & Area & Hits & $\begin{array}{l}\text { CFR } \\
\text { Title }\end{array}$ & Area & Hits \\
\hline 1 & General Provisions & 0 & 26 & Internal Revenue & 0 \\
\hline 2 & [Reserved] & 0 & 27 & $\begin{array}{l}\text { Alcohol, Tobacco Products and } \\
\text { Firearms }\end{array}$ & 0 \\
\hline 3 & The President & 0 & 28 & Judicial Administration & 1 \\
\hline 4 & Accounts & 0 & 29 & Labor & 15 \\
\hline 5 & Administrative Personnel & 3 & 30 & Mineral Resources & 6 \\
\hline 6 & [Reserved] & 0 & 31 & Money and Finance: Treasury & 1 \\
\hline 7 & Agriculture & 3 & 32 & National Defense & 2 \\
\hline 8 & Aliens and Nationality & 0 & 33 & Navigation and Navigable Waters & 1 \\
\hline 9 & $\begin{array}{l}\text { Animals and Animal } \\
\text { Products }\end{array}$ & 0 & 34 & Education & 0 \\
\hline 10 & Energy & 8 & 35 & Panama Canal & 0 \\
\hline 11 & Federal Elections & 0 & 36 & Parks, Forests, and Public Property & 0 \\
\hline 12 & Banks and Banking & 0 & 37 & $\begin{array}{l}\text { Patents, Trademarks, and } \\
\text { Copyrights }\end{array}$ & 0 \\
\hline 13 & $\begin{array}{l}\text { Business Credit and } \\
\text { Assistance }\end{array}$ & 0 & 38 & $\begin{array}{l}\text { Pensions, Bonuses, and Veterans' } \\
\text { Relief }\end{array}$ & 0 \\
\hline 14 & Aeronautics and Space & 3 & 39 & Postal Service & 0 \\
\hline 15 & $\begin{array}{l}\text { Commerce and Foreign } \\
\text { Trade }\end{array}$ & 253 & 40 & Protection of Environment & 122 \\
\hline 16 & Commercial Practices & 3 & 41 & $\begin{array}{l}\text { Public Contracts and Property } \\
\text { Management }\end{array}$ & 3 \\
\hline 17 & $\begin{array}{l}\text { Commodity and Securities } \\
\text { Exchanges }\end{array}$ & 2 & 42 & Public Health & 0 \\
\hline 18 & $\begin{array}{l}\text { Conservation of Power and } \\
\text { Water Resources }\end{array}$ & 4 & 43 & Public Lands: Interior & 1 \\
\hline 19 & Customs Duties & 0 & 44 & $\begin{array}{l}\text { Emergency Management and } \\
\text { Assistance }\end{array}$ & 0 \\
\hline 20 & Employees' Benefits & 0 & 45 & Public Welfare & 2 \\
\hline 21 & Food and Drugs & 11 & 46 & Shipping & 34 \\
\hline 22 & Foreign Relations & 1 & 47 & Telecommunication & 8 \\
\hline 23 & Highways & 0 & 48 & $\begin{array}{l}\text { Federal Acquisition Regulations } \\
\text { System }\end{array}$ & 1 \\
\hline 24 & $\begin{array}{l}\text { Housing and Urban } \\
\text { Development }\end{array}$ & 5 & 49 & Transportation & 5 \\
\hline 25 & Indians & 3 & 50 & Wildlife and Fisheries & 0 \\
\hline
\end{tabular}




\section{Appendix 5}

References to NIST and NBS Traceability and Calibration in the Code of Federal Regulations

\begin{tabular}{|c|c|c|c|c|}
\hline Document Number & Title of Document & $\begin{array}{l}\text { Edition } \\
\text { Date }\end{array}$ & $\begin{array}{l}\text { Incorporated } \\
\text { By }\end{array}$ & Location in CFR \\
\hline $\begin{array}{l}\text { Traceability / } \\
\text { calibration }\end{array}$ & $\begin{array}{l}\text { References are made to the NBS program for the Certification of Capability of State } \\
\text { Measurement Laboratories for describing the criteria by which state, county and city } \\
\text { labs could be automatically approved by the Grain Inspection, Packers and Stockyard } \\
\text { Administration as qualified metrology labs and Type Evaluation Labs }\end{array}$ & & $\begin{array}{l}\text { USDA/GIPS } \\
\text { A }\end{array}$ & 7 CFR 802.1 \\
\hline Calibration & $\begin{array}{l}\text { This regulation requires that dosimetry equipment must be calibrated using a system } \\
\text { or source traceable to NIST as one option of a condition to be met. The second } \\
\text { condition that needs to be satisfied requires that "the system must have been calibrated } \\
\text { within the previous } 4 \text { years. Eighteen to thirty months after that calibration, the system } \\
\text { must have been intercompared with another dosimetry system that was calibrated } \\
\text { within the past } 24 \text { months by NIST or by a calibration laboratory accredited by the } \\
\text { AAPM - American Association of Physicists in Medicine." }\end{array}$ & & $\mathrm{DOE} / \mathrm{NRC}$ & 10 CFR 35.630(a)(1,2) \\
\hline Calibration & $\begin{array}{l}\text { In defining the test methods and measurements as part of the Uniform Test Method for } \\
\text { Measuring Average Lamp Efficacy (LE) and Color Rendering Index (CRI) of Electric } \\
\text { Lamps, this regulation requires that "all lumen measurements made with instruments } \\
\text { calibrated to the devalued NIST lumen after January 1, 1996, shall be multiplied by } \\
1.011 "\end{array}$ & & DOE & $\begin{array}{l}\text { Appendix R to Subpart B } \\
\text { of } 10 \text { CFR } 430 \text { (4) }\end{array}$ \\
\hline Traceability & $\begin{array}{l}\text { This regulation states the requirements for calibration and checking of measurement } \\
\text { systems used in the "Measurement of Airplane Noise Received on the Ground". In } \\
\text { particular, this regulation states that "Within six months of each test series the output } \\
\text { of the noise generator must be determined by a method traceable to the U.S. National } \\
\text { Institute of Standards and Technology or to an equivalent national standards } \\
\text { laboratory as determined by the FAA...". }\end{array}$ & & DOT/FAA & $\begin{array}{l}\text { 14 CFR 36 Appendix A } \\
\text { (A36.3.9.5) }\end{array}$ \\
\hline Traceability & $\begin{array}{l}\text { This regulation states the requirements for calibration and checking of measurement } \\
\text { systems used in the "Measurement of Airplane Noise Received on the Ground". In } \\
\text { particular, this regulation states that "Within six months of each test series the output } \\
\text { of the sound calibrator must be determined by a method traceable to the U.S. National } \\
\text { Institute of Standards and Technology or to an equivalent national standards } \\
\text { laboratory as determined by the FAA...". }\end{array}$ & & DOT/FAA & $\begin{array}{l}\text { 14 CFR 36 Appendix A } \\
\text { (A36.3.9.7) }\end{array}$ \\
\hline Traceability & $\begin{array}{l}\text { This regulation states the requirements for calibration and checking of measurement } \\
\text { systems used in the "Measurement of Airplane Noise Received on the Ground". In } \\
\text { particular, this regulation states that "Alternatively, within six months of each test } \\
\text { series the insertion loss of the windscreen may be determined by a method traceable to } \\
\text { the U.S. National Institute of Standards and Technology or an equivalent national } \\
\text { standards laboratory as determined by the FAA...". }\end{array}$ & & DOT/FAA & $\begin{array}{l}\text { 14 CFR Appendix H } \\
\text { A36.3.9.10 }\end{array}$ \\
\hline
\end{tabular}

\section{Appendix 5}




\begin{tabular}{|c|c|c|c|c|}
\hline & $\begin{array}{l}\text { In defining the calibrations required while measuring helicopter noise received at the } \\
\text { ground, this section in the Appendix requires that "A performance calibration analysis } \\
\text { of each piece of calibration equipment, including pistonphones, reference } \\
\text { microphones, and voltage insert devices, must have been made during the six calendar } \\
\text { months preceding the beginning of each day's test series. Each calibration must be } \\
\text { traceable to the National Bureau of Standards."(MANDATORY) }\end{array}$ & & DOT/FAA & $\begin{array}{l}\text { 14 CFR Appendix H } \\
\text { H36.109 (e)(7) }\end{array}$ \\
\hline Traceability & $\begin{array}{l}\text { This section of the Appendix to the regulation pertains to measurement of helicopter } \\
\text { noise received on the ground. In defining the calibration requirements of the } \\
\text { measuring system and components of the recording system, the regulation states that } \\
\text { "A performance calibration analysis of each piece of calibration equipment, including } \\
\text { acoustic calibrators, reference microphones, and voltage insertion devices, must have } \\
\text { been made during the six calendar months preceding the beginning of the helicopter } \\
\text { flyover series. Each calibration shall be traceable to the National Institute of Standards } \\
\text { and Technology."(MANDATORY) }\end{array}$ & & DOT/FAA & $\begin{array}{l}\text { 14 CFR 36 Appendix J } \\
(\mathrm{J} 36.107 \text { (e)(2)(iii)) }\end{array}$ \\
\hline Calibration & $\begin{array}{l}\text { As part of the specifications in the Test Method To Determine the Flammability and } \\
\text { Flame Propagation Characteristics of Thermal/Acoustic Insulation Materials when } \\
\text { exposed to both a radiant heat source and a flame, this part (Part VI, Appendix F to } \\
\text { 14CFR25) requires that the standard transducer used for the calorimeter calibration, } \\
\text { must in turn be calibrated against a primary standard traceable to NIST. }\end{array}$ & & DOT/FAA & $\begin{array}{l}\text { 14 CFR } 25 \text { Appendix F } \\
\text { PartVI(b)(7)(ii)(C) }\end{array}$ \\
\hline NBS Calibration & $\begin{array}{l}\text { This regulation stipulates the procedures used to calibrate radiation instruments used } \\
\text { in test procedures for measuring critical radiant flux. The procedures state that for total } \\
\text { heat flux meters "the total flux meter shall be calibrated by the National Bureau of } \\
\text { Standards, (direct request for such calibration services to the: Radiometric Physics } \\
\text { Division, 534, National Bureau of Standards (NBS), Washington, DC 20234.), or, } \\
\text { alternatively, its calibration shall be developed by transfer calibration methods with an } \\
\text { NBS calibrated flux meter."..(MANDATORY). These procedures are stated as part } \\
\text { of the interim safety standards for cellulose insulation. }\end{array}$ & & CPSC & 16 CFR 1209.8(b) \\
\hline Unknown & $\begin{array}{l}\text { This regulation states that "The National Bureau of Standards in } 1972 \text { estimated that } \\
600,000 \text { young children have unduly high lead blood content" as part of the CPSC's } \\
\text { findings about the risk of injury to children due to lead poisoning. No further } \\
\text { reference is made to the source of this information, i.e., no citation. }\end{array}$ & & CPSC & 16 CFR 1303.5(a)(5) \\
\hline $\begin{array}{l}\text { NIST report - NIST } \\
\text { Test Procedure } \\
\text { published through API }\end{array}$ & $\begin{array}{l}\text { Labeling requirements - A manufacturer or other seller may represent, on a label on a } \\
\text { container of processed used oil, that such oil is substantially equivalent to new oil for } \\
\text { use as engine oil only if the manufacturer has determined that the oil is substantially } \\
\text { equivalent to new oil for use as engine oil in accordance with the NIST test } \\
\text { procedures prescribed under } \$ 311.4 \text { of this part, and has based the representation on } \\
\text { that determination (MANDATORY). }\end{array}$ & 1995 & FTC & 16 CFR 311.5 \\
\hline
\end{tabular}

Appendix 5 
NIST test proceduresused to establish penalties in case of noncompliance

Traceability

\begin{tabular}{|l|} 
\\
\\
Traceability / \\
\hline
\end{tabular}

calibration

Traceability

NBS weights and

measures

NBS coupler
Prohibited acts - A manufacturer or other seller may represent, on a label on a

container of processed used oil, that such oil is substantially equivalent to new oil for use as engine oil only if the manufacturer has determined that the oil is substantially equivalent to new oil for use as engine oil in accordance with the NIST test procedures prescribed under $\S 311.4$ of this part, and has based the representation on that determination(MANDATORY)

An audiometer calibration set is identified as "a device that consists of an acoustic cavity of known volume, a sound level meter, a microphone with calibration traceable to the National Bureau of Standards, oscillators, frequency counters, microphone amplifiers, and a recorder. The device can measure selected audiometer test frequencies at a given intensity level, and selectable audiometer attenuation settings at given test frequency." This is within the context of identification of diagnostic devices, particularly Ear, Nose and Throat devices.

This sub-section defines "Traceable to a national standard means an instrument is calibrated at either the National Institute of Standards and Technology (NIST) or at a calibration laboratory that participates in a proficiency program with NIST at least once every 2 years and the results of the proficiency test conducted within 24 months of calibration show agreement within \pm 3 percent of the national standard in the mammography energy range."

This regulation requires that as part of laboratory qualifications applicable to all testing laboratories participating in the program including manufacturer's laboratories and the administrator's own laboratories when designated in the specific program, each laboratory shall, "Provide a description of the applicable standards and calibration equipment being used and the calibration procedures followed, including National Bureau of Standards traceability, when applicable. List outside organizations providing calibration services, if used."

"b) All weights and measure shall conform to standards set by the National Bureau of Standards and to standards, if any, set by the tribe and, if not in conflict with tribal regulations, to the standards set by the State". Part of the Health and Sanitation requirements for general business practices on certain Indian reservations. "Appendix E to \$1910.95-Acoustic Calibration of Audiometers. This Appendix is Mandatory. Audiometer calibration shall be checked acoustically, at least annually, according to the procedures described in this appendix. The equipment necessary to perform these measurements is a sound level meter, octave-band filter set, and a National Bureau of Standards 9A coupler. In making these measurements, the accuracy of the calibrating equipment shall be sufficient to determine that the audiometer is within the tolerances permitted by American Standard Specification for Audiometers, S3.6-1969."

\begin{tabular}{|c|c|c|}
\hline \multirow[t]{2}{*}{1996} & FTC & 16 CFR 311.6 \\
\hline & HHS/FDA & 21 CFR 874.1080(a) \\
\hline & HHS/FDA & 21 CFR 900.2 \\
\hline & HUD & 24 CFR 200.935(e)(2)(iii) \\
\hline No date & Indian Affairs & 25 CFR 141.17 \\
\hline No date & DOL/OSHA & 29 CFR 1910.95 \\
\hline
\end{tabular}




\begin{tabular}{|c|c|c|c|}
\hline Calibration & $\begin{array}{l}\text { Regulations defining the exemptions to the general duties of persons accredited to } \\
\text { certificate (sic) vessels' cargo gear refer to traceability to NBS as "Dynamometers or } \\
\text { other recording test equipment owned by an accredited person shall have been tested } \\
\text { for accuracy within the six months next preceding application for accreditation or } \\
\text { renewal of same. Such test shall be performed with calibrating equipment which has } \\
\text { been checked in turn so that indications are traceable to the National Bureau of } \\
\text { Standards." }\end{array}$ & DOL/OSHA & 29 CFR 1919.10(d) \\
\hline Traceability/Calibration & $\begin{array}{l}\text { Regulations defining the exemptions to the general duties of persons accredited to } \\
\text { certificate (sic) shore-based material handling devices refer to traceability to NBS as } \\
\text { "All required unit proof load tests shall be carried out by the use of weights as a dead } \\
\text { load. Only where this is not possible may dynamometers or other recording test } \\
\text { equipment be used. Any such recording test equipment owned by an accredited person } \\
\text { shall have been tested for accuracy within the } 6 \text { months next preceding application for } \\
\text { accreditation or renewal thereof. Such test shall be performed with calibrating } \\
\text { equipment which has been checked in turn so that indications are traceable to the } \\
\text { National Bureau of Standards" }\end{array}$ & DOL/OSHA & 29 CFR 1919.60(c) \\
\hline Traceability/Calibration & $\begin{array}{l}\text { As part of the product testing requirements for testing by third party of the applicants, } \\
\text { this regulation states that "Unless otherwise specified in the subpart, test instruments } \\
\text { shall be calibrated at least as frequently as, and according to, the instrument } \\
\text { manufacturer's specifications, using calibration standards traceable to those set by the } \\
\text { National Bureau of Standards, U.S. Department of Commerce or other nationally } \\
\text { recognized standards and accurate to at least one significant figure beyond the desired } \\
\text { accuracy" }\end{array}$ & DOL/MSHA & 30 CFR 7.4(b) \\
\hline Traceability/Calibration & $\begin{array}{l}\text { As part of the QA requirements for testing by third party or applicants, this regulation } \\
\text { states that "Unless otherwise specified in the subparts, calibrate instruments used for } \\
\text { the inspection and testing of critical characteristics at least as frequently as, and } \\
\text { according to, the instrument manufacturer's specifications, using calibration standards } \\
\text { traceable to those set by the National Bureau of Standards, U.S. Department of } \\
\text { Commerce or other nationally recognized standards and use instruments accurate to at } \\
\text { least one significant figure beyond the desired accuracy" }\end{array}$ & DOL/MSHA & 30 CFR 7.7(b) \\
\hline Traceability & $\begin{array}{l}\text { This regulation requires that "Calibration gas values shall be traceable to the National } \\
\text { Institute for Standards and Testing (NIST), "Standard Reference Materials" (SRMs). } \\
\text { The analytical accuracy of the calibration gas values shall be within } 2.0 \text { percent of } \\
\text { NIST gas standards" as part of the test equipment requirements for diesel engines } \\
\text { intended for use in underground coal mines(MANDATORY). }\end{array}$ & DOL/MSHA & 30 CFR 7.86(b)(16) \\
\hline Traceability & $\begin{array}{l}\text { This regulation states that "Span gas values shall be traceable to NIST SRMs. The } \\
\text { analytical accuracy of the span gas values shall be within } 2.0 \text { percent of NIST gas } \\
\text { standards" as part of the test equipment requirements for diesel engines intended for } \\
\text { use in underground coal mines (MANDATORY). }\end{array}$ & DOL/MSHA & 30 CFR 7.86(b)(17) \\
\hline
\end{tabular}




\begin{tabular}{|c|c|c|c|}
\hline Calibration & $\begin{array}{l}\text { States that "Light measuring instruments shall be properly calibrated and maintained. } \\
\text { Instruments shall be calibrated against standards traceable to the National Bureau of } \\
\text { Standards and color corrected to the Commission Internationale de l'Eclairage (CIE) } \\
\text { Spectral Luminous Curve" as a requirement for procedures to be followed in } \\
\text { measuring luminous intensity (MANDATORY). }\end{array}$ & DOL/MSHA & 30 CFR 75.1719-3 \\
\hline Measurement & $\begin{array}{l}\text { Requires that "Engine flywheel torque readout must meet one of the two following } \\
\text { standards for accuracy" both of which refer to the NIST true value, to meet the stated } \\
\text { dynamometer and engine equipment specifications(MANDTORY). }\end{array}$ & EPA & 40 CFR 1065.105(a)(2) \\
\hline Traceability & $\begin{array}{l}\text { Requires that "Flow meters must have accuracy and precision of } \pm 2 \text { percent of point or } \\
\text { better and be traceable to NIST standards" as part of the requirements for equipment } \\
\text { and analyzers. }\end{array}$ & EPA & 40 CFR 1065.150(a) \\
\hline Traceability & $\begin{array}{l}\text { For meeting the requirements that analytical gases have to comply with for accuracy } \\
\text { and purity specifications the regulation states that "The calibration gases in paragraph } \\
\text { (c)(1) of this section must be traceable to within one percent of NIST gas standards or } \\
\text { other gas standards we have approved. Span gases in paragraph (c)(1) of this section } \\
\text { must be accurate to within two percent of true concentration, where true concentration } \\
\text { refers to NIST gas standards, or other gas standards we have approved." }\end{array}$ & EPA & 40 CFR 1065.250(c)(2) \\
\hline Traceability & $\begin{array}{l}\text { States that gases other that those specifically stated can be used provided that they } \\
\text { meet the requirements that "they are traceable to within } \pm 2 \text { percent of NIST gas } \\
\text { standards or other standards we have approved" as part of the requirements that } \\
\text { analytical gases have to comply with to meet accuracy and purity specifications. }\end{array}$ & EPA & 40 CFR $1065.250(\mathrm{c})(3)(\mathrm{i})$ \\
\hline Traceability & $\begin{array}{l}\text { Requires a knowledge of "the concentration of primary gases used for blending to an } \\
\text { accuracy of at least } \pm 1 \text { percent, traceable to NIST gas standards or other gas standards } \\
\text { we have approved" for purposes of "generate calibration and span gases using } \\
\text { precision blending devices (gas dividers) to dilute gases with purified nitrogen or with } \\
\text { purified synthetic air" as part of the requirements that analytical gases have to comply } \\
\text { with to meet accuracy and purity specifications. }\end{array}$ & EPA & 40 CFR $1065.250(\mathrm{c})(4)$ \\
\hline Traceability & $\begin{array}{l}\text { Exempts the need for approval to be sought for using international calibration } \\
\text { standards, if the "standards that have been shown to be traceable to NIST standards". } \\
\text { This applies to analyzer and equipment calibration and is stated as part of the test } \\
\text { procedures and equipment requirements. }\end{array}$ & EPA & 40 CFR 1065.305(b) \\
\hline Traceability & $\begin{array}{l}\text { For purposes of torque calibration "the NIST "true value" torque is defined as the } \\
\text { torque calculated by taking the product of an NIST traceable weight or force and a } \\
\text { sufficiently accurate horizontal distance along a lever arm, corrected for the lever } \\
\text { arm's hanging torque". }\end{array}$ & EPA & 40 CFR 1065.315 \\
\hline Traceability & $\begin{array}{l}\text { Calibration weights used for calibration of torque-measuring devices have to be } \\
\text { traceable to NIST weights. }\end{array}$ & EPA & $\begin{array}{l}40 \text { CFR } 1065.315(a)(1) \\
\text { (b)(1) }\end{array}$ \\
\hline Measurement & $\begin{array}{l}\text { Defines the term "accuracy" to mean "the maximum difference between a measured or } \\
\text { calculated value and the true value, where the true value is determined by NIST". }\end{array}$ & & 40 CFR 1065.1001 \\
\hline
\end{tabular}




\begin{tabular}{|c|c|c|c|}
\hline Traceability & $\begin{array}{l}\text { A stock solution is defined as "A solution containing an analyte that is prepared using } \\
\text { a reference material traceable to EPA, the National Institute of Science and } \\
\text { Technology (NIST), or a source that will attest to the purity and authenticity of the } \\
\text { reference material" as part of the definitions pertaining to Method 1613, Revision B } \\
\text { for the determination of Tetra- Through Octa-Chlorinated Dioxins and Furans by } \\
\text { Isotope Dilution HRGC/HRMS as one of the Methods for Organic Chemical Analysis } \\
\text { of Municipal and Industrial Wastewater. }\end{array}$ & EPA & $\begin{array}{l}40 \text { CFR } 136 \text { Appendix A; } \\
\text { Method 1613, Rev.B } 24.2\end{array}$ \\
\hline Traceability & $\begin{array}{l}\text { Method } 1650 \text {-Adsorbable Organic Halides by Adsorption and Coulometric Titration, } \\
\text { and Method } 1653 \text { - Chlorinated Phenolics in Wastewater by In Situ Acetylation and } \\
\text { GCMS define stock solution as "a solution containing an analyte that is prepared using } \\
\text { a reference material traceable to EPA, the National Institute of Science and } \\
\text { Technology (NIST), or a source that will attest to the purity and authenticity of the } \\
\text { reference material". }\end{array}$ & EPA & $\begin{array}{l}40 \text { CFR } 430 \text { Appendix A, } \\
\text { Method } 1650,18.2 \\
\text { Method } 1653,20.2\end{array}$ \\
\hline $\begin{array}{l}\text { EPA/NIST Mass Spec } \\
\text { Library }\end{array}$ & $\begin{array}{l}\text { It is advised that the most recent version of the EPA/NIST Mass Spectral Library be } \\
\text { available, to be used as part of the data system where the computer system has to be } \\
\text { interfaced to the mass spec and the "system must allow the continuous acquisition and } \\
\text { storage on machine-readable media of all mass spectra obtained throughout the } \\
\text { duration of the chromatographic program". This forms part of the procedures for } \\
\text { Determination of Crude Oil Contamination in Non-Aqueous Drilling Fluids by Gas } \\
\text { Chromatography/Mass Spectrometry (GC/MS). }\end{array}$ & EPA & $\begin{array}{l}\text { 40 CFR } 435 \text { Appendix 5; } \\
6.3 .4\end{array}$ \\
\hline NBS Calibration & $\begin{array}{l}\text { As part of the calibration procedures for flow measurements defined under the } \\
\text { Reference Method for the Determination of Sulfur Dioxide in the Atmosphere } \\
\text { (Pararosaniline Method) it is required that "Flow measuring devices used for the on- } \\
\text { site flow measurements required in } 9.4 .2 \text { must be calibrated against a reliable flow or } \\
\text { volume standard such as an NBS traceable bubble flowmeter or calibrated wet test } \\
\text { meter". }\end{array}$ & EPA & $\begin{array}{l}\text { 40 CFR 50 Appendix A } \\
9.4 .1\end{array}$ \\
\hline Traceability & $\begin{array}{l}\text { APPENDIX B -- REFERENCE METHOD FOR THE DETERMINTION OF } \\
\text { PARTICULATE MATTER IN THE ATMOSPHERE (NBS Traceable) - States that } \\
\text { equipment required for certifying a flow rate transfer standard includes a positive } \\
\text { displacement standard volume meter traceable to the National Bureau of Standards }\end{array}$ & EPA & $\begin{array}{l}\text { 40 CFR 50 Appendix B; } \\
9.2 .1\end{array}$ \\
\hline NBS SRM traceable & $\begin{array}{l}\text { Requirements for reagents used in calibration procedures stated under Measurement } \\
\text { Principle and Calibration Procedure for the Measurement of Carbon Monoxide in the } \\
\text { Atmosphere (Non-Dispersive Infrared Photometry), defined NATIONAL PRIMARY } \\
\text { AND SECONDARY AMBIENT AIR QUALITY STANDARDS under the national } \\
\text { primary and secondary ambient air quality standards, it is required that "Cylinder(s) of } \\
\text { CO in air containing appropriate concentrations(s) of CO suitable for the selected } \\
\text { operating range of the analyzer under calibration; CO standards for the dilution } \\
\text { method may be contained in a nitrogen matrix if the zero air dilution ratio is not less } \\
\text { than 100:1. The assay of the cylinder(s) must be traceable either to a National Bureau } \\
\text { of Standards (NBS) CO in air Standard Reference Material (SRM) or to an NBS/EPA- } \\
\text { approved commercially available Certified Reference Material (CRM)." }\end{array}$ & EPA & $\begin{array}{l}40 \text { CFR } 50 \text { Appendix C } \\
3.1\end{array}$ \\
\hline
\end{tabular}

Appendix 5 


\begin{tabular}{|c|c|c|c|}
\hline Traceability & $\begin{array}{l}\text { APPENDIX D -- MEASUREMENT AND CALIBRATION PROCEDURE FOR } \\
\text { THE MEASUREMENT OF OZONE (NBS Traceable) - States that in calibration of } \\
\text { ozone analyzers, the flow rate through the O3 generator and the dilution air flow rate } \\
\text { (FD) be measured with a reliable flow or volume standard traceable to NBS. }\end{array}$ & EPA & $\begin{array}{l}\text { 40 CFR 50 Appendix D; } \\
\text { 5.5.7 }\end{array}$ \\
\hline NBS SRM 1684 & $\begin{array}{l}\text { In stating the Measurement Principle and Calibration Procedure for the Measurement } \\
\text { of Nitrogen Dioxide in the Atmosphere (Gas Phase Chemiluminescence), under the } \\
\text { National Primary and Secondary Ambient Air Quality Standards, for calibration using } \\
\text { gas phase titration of an NO standard with ozone, the NO concentration standard } \\
\text { should be a "Gas cylinder standard containing } 50 \text { to } 100 \text { ppm NO in N2 with less than } \\
1 \text { ppm NO2". Further, "This standard must be traceable to a National Bureau of } \\
\text { Standards (NBS) NO in N2 Standard Reference Material (SRM } 1683 \text { or SRM 1684), } \\
\text { an NBS NO2 Standard Reference Material (SRM 1629), or an NBS/EPA-approved } \\
\text { commercially available Certified Reference Material (CRM) ". Similarly, for } \\
\text { calibration using NO2 permeation devices "Calibration standards are required for both } \\
\text { NO and NO2. The reference standard for the calibration may be either an NO or NO2 } \\
\text { standard, and must be traceable to a National Bureau of Standards (NBS) NO in N2 } \\
\text { Standard Reference Material (SRM 1683 or SRM 1684), and NBS NO2 Standard } \\
\text { Reference Material (SRM 1629), or an NBS/EPA-approved commercially available } \\
\text { Certified Reference Material (CRM)". }\end{array}$ & EPA & $\begin{array}{l}\text { 40 CFR 50 Appendix F } \\
1.3 .1,2.3 .1\end{array}$ \\
\hline Calibration/traceability & $\begin{array}{l}\text { The Reference Method for the Determination of Particulate Matter as PM10 in the } \\
\text { Atmosphere requires that "the flow rate transfer standard must be suitable for the } \\
\text { sampler's operating flow rate and must be calibrated against a primary flow or volume } \\
\text { standard that is traceable to the National Bureau of Standards (NBS)". It is further } \\
\text { required that a calibration relationship (e.g., an equation or family of curves) be } \\
\text { established such that traceability to the primary standard is accurate to within } 2 \\
\text { percent over the expected range of ambient conditions (i.e., temperatures and } \\
\text { pressures) under which the transfer standard will be used and the transfer standard } \\
\text { periodically recalibrated. }\end{array}$ & EPA & $\begin{array}{l}40 \text { CFR } 50 \text { Appendix J } \\
7.3,8.2 .2\end{array}$ \\
\hline Traceability & $\begin{array}{l}\text { APPENDIX L TO PART } 50 \text {-- REFERCNCE METHOD FOR THE } \\
\text { DETERMINATION OF FINE PARTICULATE MATTER (NIST Traceable) - States } \\
\text { that dimension of the impaction jets used in impactors must be verified by the } \\
\text { manufacturer using Class ZZ go/no-go plug gauges that are traceable to NIST, and } \\
\text { that standard used for calibrating or verifying the sampler's flow rate measurement } \\
\text { device have its own certification and be traceable to a National Institute of Standards } \\
\text { and Technology (NIST) primary standard for volume or flow rate. }\end{array}$ & EPA & $\begin{array}{l}\text { 40 CFR } 50 \text { Appendix L; } \\
\text { 7.3.4.1; }\end{array}$ \\
\hline Traceability & $\begin{array}{l}\text { Requires that a flow rate standard used in the Reference Method for the Determination } \\
\text { of Fine Particulate Matter as PM } 2.5 \text { in the Atmosphere must have its own certification } \\
\text { and be traceable to a National Institute of Standards and Technology (NIST) primary } \\
\text { standard for volume or flow rate. }\end{array}$ & & $\begin{array}{l}\text { 40 CFR 50 Appendix L; } \\
9.1 .2,9.2 .2\end{array}$ \\
\hline
\end{tabular}




\begin{tabular}{|c|c|c|c|}
\hline & $\begin{array}{l}\text { Appendix M to Part } 50 \text {-- Reference Method for the Determination of Particulate } \\
\text { Matter as PM10 in the Atmosphere - Requires calibration of flow rate transfer } \\
\text { standard against a primary flow or volume standard traceable to NIST }\end{array}$ & EPA & $\begin{array}{l}\text { 40 CFR } 50 \text { Appendix M; } \\
7.3 ; 8.2 .2\end{array}$ \\
\hline Traceability & $\begin{array}{l}\text { If using Method } 205 \text { "Verification of Gas Dilution Systems for Field Instrument } \\
\text { Calibrations" as a recommended test method for state implementation plans under the } \\
\text { requirements for preparation, adoption, and submittals of implementation plans, the } \\
\text { specifications for the method state that "The gas dilution system shall be recalibrated } \\
\text { once per calendar year using NIST-traceable primary flow standards with an } \\
\text { uncertainty } \leq 0.25 \text { percent." }\end{array}$ & EPA & $\begin{array}{l}40 \text { CFR 51 Appendix N; } \\
\text { Method 205; } 2.1 .1\end{array}$ \\
\hline Traceability & $\begin{array}{l}\text { Requires that "Span and zero gases should be traceable to National Bureau of } \\
\text { Standards reference gases whenever these reference gases are available" defined as } \\
\text { part of the minimum specifications of the calibration gases used to meet the } \\
\text { requirements of minimum requirements for continuous emission monitoring and } \\
\text { recording that each State Implementation Plan has to meet under the requirements for } \\
\text { preparation, adoption, and submittals of implementation plans. }\end{array}$ & EPA & $\begin{array}{l}\text { 40 CFR 51 Appendix P; } \\
3.3\end{array}$ \\
\hline Traceability & $\begin{array}{l}\text { Requires that in calibration of steady-state test equipment "the span gases used for the } \\
\text { gas calibration shall be traceable to National Institute of Standards and Technology } \\
\text { (NIST) standards } \pm 2 \% \text {..." This meets the inspection/maintenance program } \\
\text { requirements in both ozone and carbon monoxide (CO) nonattainment areas, } \\
\text { depending upon population and nonattainment classification or design value. These } \\
\text { are part of the requirements for preparation, adoption and submittal of implementation } \\
\text { plans. }\end{array}$ & EPA & $\begin{array}{l}40 \text { CFR 51Subpart S, } \\
\text { Appendix A (d)(3) }\end{array}$ \\
\hline Traceability & $\begin{array}{l}\text { Requires that all calibration gases used in procedures for determining the volatile } \\
\text { organic compounds (VOC) content of captured gas stream shall be traceable to NIST } \\
\text { standards and shall be certified by the manufacturer to } \pm 1 \text { percent of the tag value. The } \\
\text { procedure is intended to be used as a segment in the development of liquid/gas or } \\
\text { gas/gas protocols for determining VOC capture efficiency (CE) for surface coating } \\
\text { and printing operations This procedure pertains to testing for captured VOC } \\
\text { emissions, part of the VOM measurement techniques for capture efficiency and relates } \\
\text { to the approval and promulgation of implementation plans for Illinois. }\end{array}$ & EPA & $\begin{array}{l}40 \text { CFR 52 Subpart O, } \\
\text { Appendix B; G.1; 2.1.9 }\end{array}$ \\
\hline Traceability & $\begin{array}{l}\text { Requires that all calibration gases used in procedures for determining the volatile } \\
\text { organic compounds (VOC) content of captured gas streams shall be traceable to NIST } \\
\text { standards and shall be certified by the manufacturer to } \pm 1 \text { percent of the tag value. The } \\
\text { test is intended to be used as a segment in the development of a gas/gas protocol in } \\
\text { which fugitive emissions are measured for determining VOC capture efficiency (CE) } \\
\text { for surface coating and printing operations. This procedure pertains to testing for } \\
\text { captured VOC emissions (dilution technique), part of the VOM measurement } \\
\text { techniques for capture efficiency and relates to the approval and promulgation of } \\
\text { implementation plans for Illinois. }\end{array}$ & EPA & $\begin{array}{l}40 \text { CFR } 52 \text { Subpart O, } \\
\text { Appendix B; G.2; } 2.1 .9\end{array}$ \\
\hline
\end{tabular}




\begin{tabular}{|c|c|c|c|}
\hline Traceability & $\begin{array}{l}\text { Requires that all calibration gases used in procedures for determining the fugitive } \\
\text { volatile organic compounds (VOC) emissions from a building enclosure (BE) shall be } \\
\text { traceable to NIST standards and shall be certified by the manufacturer to } \pm 1 \text { percent of } \\
\text { the tag value. The procedure is intended to be used as a segment in the development of } \\
\text { liquid/gas or gas/gas protocols for determining VOC capture efficiency (CE) for } \\
\text { surface coating and printing operations. This procedure forms part of the VOM } \\
\text { measurement techniques for capture efficiency and relates to the approval and } \\
\text { promulgation of implementation plans for Illinois. }\end{array}$ & EPA & $\begin{array}{l}40 \text { CFR } 52 \text { Subpart O, } \\
\text { Appendix B; F.2; } 2.1 .9\end{array}$ \\
\hline Traceability & $\begin{array}{l}\text { Requires that all calibration gases used in procedures for determining the input of } \\
\text { volatile organic compounds (VOC) shall be traceable to NIST standards and shall be } \\
\text { certified by the manufacturer to } \pm 1 \text { percent of the tag value. The procedure is intended } \\
\text { to be used as a segment in the development of liquid/gas protocols for determining } \\
\text { VOC capture efficiency (CE) for surface coating and printing operations. This } \\
\text { procedure forms part of the VOM measurement techniques for capture efficiency and } \\
\text { relates to the approval and promulgation of implementation plans for Illinois. }\end{array}$ & EPA & $\begin{array}{l}40 \text { CFR 52 Subpart O, } \\
\text { Appendix B; F.1; } 2.1 .9\end{array}$ \\
\hline Traceability & $\begin{array}{l}\text { Requires that all calibration gases used in procedures for determining the fugitive } \\
\text { volatile organic compounds (VOC) emissions from a temporary total enclosure (TTE) } \\
\text { shall be traceable to NIST standards and shall be certified by the manufacturer to } \pm 1 \\
\text { percent of the tag value. The procedure is intended to be used as a segment in the } \\
\text { development of liquid/gas or gas/gas protocols for determining VOC capture } \\
\text { efficiency (CE) for surface coating and printing operations. This procedure forms part } \\
\text { of the VOM measurement techniques for capture efficiency and relates to the approval } \\
\text { and promulgation of implementation plans for Illinois. }\end{array}$ & EPA & $\begin{array}{l}40 \text { CFR } 52 \text { Subpart O, } \\
\text { Appendix B; L; } 2.2 .22\end{array}$ \\
\hline Traceability & $\begin{array}{l}\text { Requires that an applicant for a reference or equivalent method determination for } \\
\text { testing under the ambient air monitoring reference and equivalent methods regulations } \\
\text { "shall maintain and include records of all relevant measuring equipment, including the } \\
\text { make, type, and serial number or other identification, and most recent calibration with } \\
\text { identification of the measurement standard or standards used and their National } \\
\text { Institute of Standards and Technology (NIST) traceability". The intent of these records } \\
\text { is to demonstrate "the measurement capability of each item of measuring equipment } \\
\text { used for the application and include a description and justification (if needed) of the } \\
\text { measurement setup or configuration in which it was used for the tests. The calibration } \\
\text { results shall be recorded and identified in sufficient detail so that the traceability of all } \\
\text { measurements can be determined and any measurement could be reproduced under } \\
\text { conditions close to the original conditions, if necessary, to resolve any anomalies." }\end{array}$ & EPA & 40 CFR 53.4(b)(5)(i) \\
\hline
\end{tabular}




\begin{tabular}{|c|c|c|c|}
\hline Traceability & $\begin{array}{l}\text { "The diameter of the jet of each impactor manufactured for a PM2.5 sampler under the } \\
\text { impactor design specifications set forth in } 40 \text { CFR part 50, appendix L, shall be } \\
\text { verified against the tolerance specified on the drawing, using standard, NIST-traceable } \\
\text { ZZ go/no go plug gages" to verify the PM2.5 jet impactor diameter as part of the } \\
\text { required specific tests to verify conformance to critical component specifications to } \\
\text { demonstrate compliance with design specifications and manufacturing and test } \\
\text { requirement, as part of the Procedures for Testing Physical (Design) and Performance } \\
\text { Characteristics of Reference Methods and Class I Equivalent Methods for PM2.5 in } \\
\text { ambient air monitoring reference and equivalent methods (Mandatory). }\end{array}$ & EPA & 40 CFR $53.51(\mathrm{~d})(1)$ \\
\hline Traceability & $\begin{array}{l}\text { Flow rate measurement device used as part of the required test equipment for Leak } \\
\text { check test, as part of the Procedures for Testing Physical (Design) and Performance } \\
\text { Characteristics of Reference Methods and Class I Equivalent Methods for PM2.5 in } \\
\text { ambient air monitoring reference and equivalent methods must have "a range } 70 \\
\mathrm{~mL} / \mathrm{min} \text { to } 130 \mathrm{~mL} / \mathrm{min}, 2 \text { percent certified accuracy, NIST-traceable" (mandatory). }\end{array}$ & EPA & 40 CFR 53.52(c)(1) \\
\hline \multirow[t]{2}{*}{ Traceability } & $\begin{array}{l}\text { Proof of traceability to NIST (if required) for all measurement instruments used in } \\
\text { testing for leak checks needs to be submitted. This testing constitutes part of the } \\
\text { Procedures for Testing Physical (Design) and Performance Characteristics of } \\
\text { Reference Methods and Class I Equivalent Methods for PM2.5" under the ambient air } \\
\text { monitoring reference and equivalent methods. }\end{array}$ & EPA & 40 CFR 53.52(d) \\
\hline & $\begin{array}{l}\text { Flow rate meters used as part of the required test equipment in testing for flow rate } \\
\text { accuracy, regulation, measurement accuracy, and cut-off as part of the Procedures for } \\
\text { Testing Physical (Design) and Performance Characteristics of Reference Methods and } \\
\text { Class I Equivalent Methods for PM2.5 in ambient air monitoring reference and } \\
\text { equivalent methods must be "suitable for measuring and recording the actual } \\
\text { volumetric sample flow rate at the sampler downtube, with a minimum range of } 10 \text { to } \\
25 \text { actual L/min, } 2 \text { percent certified, NIST-traceable accuracy." (mandatory). }\end{array}$ & & 40 CFR 53.53(c)(1) \\
\hline Traceability & $\begin{array}{l}\text { Proof of traceability to NIST (if required) for all measurement instruments used in } \\
\text { testing for flow rate accuracy, regulation, measurement accuracy, and cut-off needs to } \\
\text { be submitted. This testing constitutes part of the Procedures for Testing Physical } \\
\text { (Design) and Performance Characteristics of Reference Methods and Class I } \\
\text { Equivalent Methods for PM2.5" under the ambient air monitoring reference and } \\
\text { equivalent methods. }\end{array}$ & EPA & 40 CFR 53.53(d) \\
\hline Traceability & $\begin{array}{l}\text { Flow rate meters used as part of the required test equipment in testing for proper } \\
\text { sampler operation following power interruptions as part of the Procedures for Testing } \\
\text { Physical (Design) and Performance Characteristics of Reference Methods and Class I } \\
\text { Equivalent Methods for PM } 2.5 \text { in ambient air monitoring reference and equivalent } \\
\text { methods must be "suitable for measuring and recording the actual volumetric sample } \\
\text { flow rate at the sampler downtube, with a minimum range of } 10 \text { to } 25 \text { actual L/min, } 2 \\
\text { percent certified, NIST-traceable accuracy." (mandatory). }\end{array}$ & EPA & 40 CFR 53.54(b)(1) \\
\hline
\end{tabular}




\begin{tabular}{|c|c|c|c|}
\hline Traceability & $\begin{array}{l}\text { Proof of traceability to NIST (if required) for all measurement instruments used in } \\
\text { testing for proper sampler operation following power interruptions needs to be } \\
\text { submitted. This testing constitutes part of the Procedures for Testing Physical (Design) } \\
\text { and Performance Characteristics of Reference Methods and Class I Equivalent } \\
\text { Methods for PM2.5" under the ambient air monitoring reference and equivalent } \\
\text { methods. }\end{array}$ & EPA & 40 CFR 53.54(c) \\
\hline Traceability & $\begin{array}{l}\text { Flow rate meters used as part of the required test equipment in testing for the effects of } \\
\text { variations in power line voltage and ambient temperature as part of the Procedures for } \\
\text { Testing Physical (Design) and Performance Characteristics of Reference Methods and } \\
\text { Class I Equivalent Methods for PM } 2.5 \text { in ambient air monitoring reference and } \\
\text { equivalent methods must be "suitable for measuring and recording the actual } \\
\text { volumetric sample flow rate at the sampler downtube, with a minimum range of } 10 \text { to } \\
25 \text { actual L/min, } 2 \text { percent certified, NIST-traceable accuracy." (mandatory). }\end{array}$ & EPA & 40 CFR 53.55(c)(3) \\
\hline Traceability & $\begin{array}{l}\text { Proof of traceability to NIST (if required) for all measurement instruments used in } \\
\text { testing for the effects of variations in power line voltage ambient temperature needs to } \\
\text { be submitted. This testing constitutes part of the Procedures for Testing Physical } \\
\text { (Design) and Performance Characteristics of Reference Methods and Class I } \\
\text { Equivalent Methods for PM2.5" under the ambient air monitoring reference and } \\
\text { equivalent methods. }\end{array}$ & EPA & 40 CFR 53.55(d) \\
\hline Traceability & $\begin{array}{l}\text { Flow rate meters used as part of the required test equipment in testing for the effects of } \\
\text { variations in ambient pressure as part of the Procedures for Testing Physical (Design) } \\
\text { and Performance Characteristics of Reference Methods and Class I Equivalent } \\
\text { Methods for PM } 2.5 \text { in ambient air monitoring reference and equivalent methods must } \\
\text { have "minimum range of } 10 \text { to } 25 \mathrm{~L} / \mathrm{min}, 2 \text { percent certified, NIST-traceable } \\
\text { accuracy" (mandatory). }\end{array}$ & EPA & 40 CFR 53.56(c)(2) \\
\hline Traceability & $\begin{array}{l}\text { Proof of traceability to NIST (if required) for all measurement instruments used in } \\
\text { testing for the effects of variations in ambient pressure needs to be submitted. This } \\
\text { testing constitutes part of the Procedures for Testing Physical (Design) and } \\
\text { Performance Characteristics of Reference Methods and Class I Equivalent Methods } \\
\text { for PM2.5" under the ambient air monitoring reference and equivalent methods. }\end{array}$ & EPA & 40 CFR 53.56(d) \\
\hline Traceability & $\begin{array}{l}\text { NIST Traceable temperature sensors are part of the required test equipment for use in } \\
\text { tests "intended to measure a candidate sampler's ability to prevent excessive } \\
\text { overheating of the PM2.5 sample collection filter (or filters) under conditions of } \\
\text { elevated solar insolation..." This testing falls under the "Procedures for Testing } \\
\text { Physical (Design) and Performance Characteristics of Reference Methods and Class I } \\
\text { Equivalent Methods for PM } 2.5 \text { " as part of the ambient air monitoring reference and } \\
\text { equivalent methods. }\end{array}$ & EPA & 40 CFR 53.57(c)(4) \\
\hline
\end{tabular}




\begin{tabular}{|c|c|c|c|}
\hline Traceability & $\begin{array}{l}\text { Proof of traceability to NIST (if required) for all measurement instruments used in the } \\
\text { tests to measure a candidate sampler's ability to prevent excessive overheating of the } \\
\text { PM2.5 sample collection filter (or filters) under conditions of elevated solar insolation } \\
\text { needs to be submitted. This testing constitutes part of the Procedures for Testing } \\
\text { Physical (Design) and Performance Characteristics of Reference Methods and Class I } \\
\text { Equivalent Methods for PM2.5" under the ambient air monitoring reference and } \\
\text { equivalent methods. }\end{array}$ & EPA & 40 CFR 53.57(d) \\
\hline Traceability & $\begin{array}{l}\text { This regulation states that documentation is required "showing evidence of } \\
\text { appropriately recent calibration, certification of calibration accuracy, and NIST- } \\
\text { traceability (if required) of all measurement instruments used in the tests" intended to } \\
\text { verify adequate aerosol transport through any modified or air flow splitting } \\
\text { components that may be used in a Class I candidate equivalent method sampler such } \\
\text { as may be necessary to achieve sequential sampling capability. This is stated as part of } \\
\text { the Procedures for Testing Physical (Design) and Performance Characteristics of } \\
\text { Reference Methods and Class I Equivalent Methods for PM2.5 under the Ambient Air } \\
\text { Monitoring Reference and Equivalent Methods. }\end{array}$ & EPA & 40 CFR 53.59(d) \\
\hline Traceability & $\begin{array}{l}\text { States that "All flow rate measurements used to calculate the test atmosphere } \\
\text { concentrations and the test results must be accurate to within } \pm 2 \text { percent, referenced to } \\
\text { a NIST-traceable primary standard"(MANDATORY). This requirement is stated for } \\
\text { sampler flow rate measurements in the test procedures for a full wind tunnel test for } \\
\text { Testing Performance Characteristics of Class II Equivalent Methods for PM } 2.5 \text { under } \\
\text { the Ambient Air Monitoring Reference and Equivalent Methods. }\end{array}$ & EPA & 40 CFR 53.62(c)(8) \\
\hline Traceability & $\begin{array}{l}\text { Defines 'Traceable' to mean "a local standard has been compared and certified, either } \\
\text { directly or via not more than one intermediate standard, to a National Institute of } \\
\text { Standards and Technology (NIST)-certified primary standard such as a NIST- } \\
\text { Traceable Reference Material (NTRM) or a NIST-certified Gas Manufacturer's } \\
\text { Internal Standard (GMIS)." }\end{array}$ & EPA & 40 CFR 58.1 \\
\hline Traceability & $\begin{array}{l}\text { Requires that "gaseous pollutant concentration standards (permeation devices or } \\
\text { cylinders of compressed gas) used to obtain test concentrations for CO, SO2, NO, and } \\
\text { NO2 must be traceable to either a National Institute of Standards and Technology } \\
\text { (NIST) NIST-Traceable Reference Material (NTRM) or a NIST-certified Gas } \\
\text { Manufacturer's Internal Standard (GMIS)" as part of the quality assurance } \\
\text { requirements for state and local air monitoring station (SLAMS) for Ambient Air } \\
\text { Quality Surveillance. }\end{array}$ & EPA & $\begin{array}{l}\text { 40CFR 58 Appendix A } \\
2.1(\mathrm{f}) 2.3 .1\end{array}$ \\
\hline
\end{tabular}




\begin{tabular}{|c|c|c|c|}
\hline Traceability & $\begin{array}{l}\text { States that "Gaseous standards (permeation tubes, permeation devices or cylinders of } \\
\text { compressed gas) used to obtain test concentrations for CO, SO2, and NO2 must be } \\
\text { traceable to either a National Institute of Standards and Technology (NIST) gaseous } \\
\text { Standard Reference Material (SRM) or an NIST/EPA-approved commercially } \\
\text { available Certified Reference Material (CRM)." Further states that "direct use of a } \\
\text { CRM as a working standard is acceptable, but direct use of an NIST SRM as a } \\
\text { working standard is discouraged because of the limited supply and expense of SRMs". } \\
\text { This requirement stated under pollutant standards as part of the Quality Assurance } \\
\text { Requirements for Prevention of Significant Deterioration (PSD) Air Monitoring for } \\
\text { Ambient Air Quality Surveillance. }\end{array}$ & EPA & $\begin{array}{l}\text { 40 CFR 58; Appendix B } \\
\text { 2.3.1 }\end{array}$ \\
\hline Traceability & $\begin{array}{l}\text { Requires that the spectrophotometer used for attenuator calibration must have an } \\
\text { "accuracy of }<0.5 \% \text { transmittance, NIST traceable calibration" as a minimum design } \\
\text { specification (MANDATORY). This is stated as part of the performance specifications } \\
\text { for Standards of Performance for New Stationary Sources. }\end{array}$ & EPA & $\begin{array}{l}\text { 40 CFR } 60 \text { Appendix B } \\
1.6 .3\end{array}$ \\
\hline Calibration & $\begin{array}{l}\text { States that an attenuator used to check the daily calibration drift and calibration error } \\
\text { of a COMS can be designated as a primary if calibrated by NIST. This is stated as part } \\
\text { of the performance specifications for Standards of Performance for New Stationary } \\
\text { Sources. }\end{array}$ & EPA & $\begin{array}{l}\text { 40 CFR } 60 \text { Appendix B } \\
\text { 1.7.1(1) }\end{array}$ \\
\hline Traceability & $\begin{array}{l}\text { This performance specification is applicable for measuring all hazardous air pollutants } \\
\text { (HAPs) which absorb in the infrared region and can be quantified using Fourier } \\
\text { Transform Infrared Spectroscopy (FTIR), as long as the performance criteria of this } \\
\text { performance specification are met. This specification is to be used for evaluating FTIR } \\
\text { continuous emission monitoring systems for measuring HAPs regulated under Title III } \\
\text { of the } 1990 \text { Clean Air Act Amendments. This specification also applies to the use of } \\
\text { FTIR CEMs for measuring other volatile organic or inorganic species. As part of the } \\
\text { performance requirements this regulation states that the "audit sample can be a } \\
\text { mixture or a single component. It must contain target analyte(s) at approximately the } \\
\text { expected flue gas concentration(s). If possible, each mixture component concentration } \\
\text { should be NIST traceable ( } \pm 2 \text { percent accuracy)". This is part of the Performance } \\
\text { Specification for Extractive FTIR Continuous Emissions Monitor Systems in } \\
\text { Stationary Sources that form the Standards of Performance for New Stationary } \\
\text { Sources. }\end{array}$ & EPA & $\begin{array}{l}\text { 40 CFR } 60 \text { Appendix B } \\
\text { 15.9.1.1 }\end{array}$ \\
\hline Traceability & $\begin{array}{l}\text { Requires that "The owner or operator shall install, calibrate, operate, and maintain a } \\
\text { temperature monitor accurate to within } \pm 5.6^{\circ} \mathrm{C}\left( \pm 10^{\circ} \mathrm{F}\right) \text { to measure the oxidation } \\
\text { temperature. The owner or operator shall verify the accuracy of the temperature } \\
\text { monitor twice each calendar year with a reference temperature monitor (traceable to } \\
\text { National Institute of Standards and Technology (NIST) standards or an independent } \\
\text { temperature measurement device dedicated for this purpose)" for sterilization } \\
\text { facilities. This is part of the monitoring requirements of the Ethylene Oxide Emissions } \\
\text { Standards for Sterilization Facilities that form the National Emission Standards for } \\
\text { Hazardous Air Pollutants for Source Categories. }\end{array}$ & EPA & 40 CFR 63.364(c)(4) \\
\hline
\end{tabular}




\begin{tabular}{|c|c|c|c|}
\hline Traceability & $\begin{array}{l}\text { Requires that "The owner or operator shall install, calibrate, operate, and maintain a } \\
\text { temperature monitor accurate to within } \pm 5.6^{\circ} \mathrm{C}\left( \pm 10^{\circ} \mathrm{F}\right) \text { to measure the oxidation } \\
\text { temperature". As an alternative to verifying the accuracy of the temperature monitor } \\
\text { with a reference temperature monitor, the operator or owner can verify the accuracy of } \\
\text { the temperature monitor "in a calibrated oven (traceable to NIST standards)". This is } \\
\text { part of the monitoring requirements of the Ethylene Oxide Emissions Standards for } \\
\text { Sterilization Facilities that form the National Emission Standards for Hazardous Air } \\
\text { Pollutants for Source Categories. }\end{array}$ & EPA & 40 CFR 63.364(c)(4) \\
\hline Traceability & $\begin{array}{l}\text { Requires the installation, calibration, operation, and maintenance of a temperature } \\
\text { monitor accurate to within } \pm 5.6^{\circ} \mathrm{C}\left( \pm 10^{\circ} \mathrm{F}\right) \text { or within } 1 \text { percent of the baseline } \\
\text { temperature, whichever is less stringent, to measure the temperature of a combustion } \\
\text { device. It is further stated that "the owner or operator shall verify the accuracy of the } \\
\text { temperature monitor once each calendar year with a reference temperature monitor } \\
\text { (traceable to National Institute of Standards and Technology (NIST) standards or an } \\
\text { independent temperature measurement device dedicated for this } \\
\text { purpose)"(MANDATORY). This is part of the monitoring requirements of National } \\
\text { Emission Standards for Marine Tank Vessel Loading Operations that form the } \\
\text { National Emission Standards for Hazardous Air Pollutants for Source Categories. }\end{array}$ & EPA & 40 CFR 63.564(e)(4) \\
\hline Traceability & $\begin{array}{l}\text { When using a carbon adsorber with steam regeneration, requires that "the owner or } \\
\text { operator will install, calibrate, maintain, and operate an integrating stream flow } \\
\text { monitoring device that is accurate within } \pm 10 \text { percent and that is capable of recording } \\
\text { the total stream mass flow for each regeneration cycle. The owner or operator will } \\
\text { install, calibrate, maintain, and operate a temperature monitor accurate to within } \\
\pm 5.6^{\circ} \mathrm{C}\left(10^{\circ} \mathrm{F}\right) \text { or within } 1 \text { percent of the baseline carbon bed temperature, whichever } \\
\text { is less stringent, to measure the carbon bed temperature". Further requires that "the } \\
\text { owner or operator shall verify the accuracy of the temperature monitor once each } \\
\text { calendar year with a reference temperature monitor (traceable to National Institute of } \\
\text { Standards and Technology (NIST) standards or an independent temperature } \\
\text { measurement device dedicated for this purpose)"(MANDATORY). This is part of the } \\
\text { monitoring requirements of National Emission Standards for Marine Tank Vessel } \\
\text { Loading Operations that form the National Emission Standards for Hazardous Air } \\
\text { Pollutants for Source Categories. }\end{array}$ & EPA & 40 CFR 63.564(g)(3) \\
\hline
\end{tabular}




\begin{tabular}{|c|c|c|c|}
\hline Traceability & $\begin{array}{l}\text { Requires the installation, calibration, operation, and maintenance of a temperature } \\
\text { monitor accurate to within } \pm 5.6^{\circ} \mathrm{C}\left( \pm 10^{\circ} \mathrm{F}\right) \text { or within } 1 \text { percent of the baseline } \\
\text { temperature, whichever is less stringent, to measure the temperature of a } \\
\text { condenser/refrigeration unit. It is further stated that "the owner or operator shall verify } \\
\text { the accuracy of the temperature monitor once each calendar year with a reference } \\
\text { temperature monitor (traceable to National Institute of Standards and Technology } \\
\text { (NIST) standards or an independent temperature measurement device dedicated for } \\
\text { this purpose)"(MANDATORY). This is part of the monitoring requirements of } \\
\text { National Emission Standards for Marine Tank Vessel Loading Operations that form } \\
\text { the National Emission Standards for Hazardous Air Pollutants for Source Categories. }\end{array}$ & EPA & 40 CFR 63.564(h)(1) \\
\hline Traceability & $\begin{array}{l}\text { Absolute Calibration Audit (ACA) is defined as "Equivalent to calibration error (CE) } \\
\text { test defined in the appropriate performance specification using NIST traceable } \\
\text { calibration standards to challenge the CEMS (continuous emissions monitoring } \\
\text { system) and assess accuracy". This definition is spelled under the Quality Assurance } \\
\text { Procedures for Continuous Emissions Monitors Used for Hazardous Waste } \\
\text { Combustors provided as an appendix to the sub-part on National Emission Standards } \\
\text { for Hazardous Air Pollutants from Hazardous Waste Combustors under the National } \\
\text { Emission Standards for Hazardous Air Pollutants for Source Categories. }\end{array}$ & EPA & $\begin{array}{l}40 \text { CFR } 63 \\
\text { Subpart EEE; Appendix }\end{array}$ \\
\hline Traceability & $\begin{array}{l}\text { This part of the regulation requires that for each continuous parameter monitoring } \\
\text { system (CPMS), except for redundant sensors, any device that is used to conduct an } \\
\text { initial validation or accuracy audit of a CPMS must have an accuracy that is traceable } \\
\text { to National Institute of Standards and Technology (NIST) standards, in addition to } \\
\text { other requirements (MANDATORY). This requirement is part of the testing and } \\
\text { initial compliance requirements under the National Emission Standards for Hazardous } \\
\text { Air Pollutants for Cellulose Products Manufacturing (subpart) that form the National } \\
\text { Emission Standards for Hazardous Air Pollutants for Source Categories. }\end{array}$ & EPA & 40 CFR 63.5545(f)(9)(i) \\
\hline Traceability & $\begin{array}{l}\text { Regulation requires that any device used to conduct an initial validation or accuracy } \\
\text { audit of CPMS (continuous parametric monitoring system) must "have an accuracy } \\
\text { that is traceable to National Institute of Standards and Technology (NIST) standards", } \\
\text { amongst other requirements (MANDATORY). This requirement is part of the testing } \\
\text { and initial compliance requirements under the National Emission Standards for } \\
\text { Hazardous Air Pollutants for Refractory Products Manufacturing (subpart) that form } \\
\text { the National Emission Standards for Hazardous Air Pollutants for Source Categories. }\end{array}$ & EPA & 40 CFR 63.9804(a)(15)(i) \\
\hline
\end{tabular}




\begin{tabular}{|c|c|c|c|}
\hline $\begin{array}{l}\text { NIST certified } \mathrm{pH} \\
\text { buffer solution }\end{array}$ & $\begin{array}{l}\text { This part of the regulation requires that an initial validation of the pH CPMS be } \\
\text { conducted by performing "a single-point calibration using an NIST-certified buffer } \\
\text { solution that is accurate to within } \pm 0.02 \mathrm{pH} \text { units at } 25^{\circ} \mathrm{C}\left(77^{\circ} \mathrm{F}\right) \text {. If the expected } \mathrm{pH} \\
\text { of the liquid that is monitored lies in the acidic range (less than } 7 \mathrm{pH}) \text {, use a buffer } \\
\text { solution with a pH value of } 4.00 \text {. If the expected pH of the liquid that is monitored is } \\
\text { neutral or lies in the basic range (equal to or greater than } 7 \mathrm{pH}) \text {, use a buffer solution } \\
\text { with a pH value of } 10.00 \text {. Place the electrode of your } \mathrm{pH} \text { CPMS in the container of } \\
\text { buffer solution. Record the } \mathrm{pH} \text { measured by your CPMS. Using the certified buffer } \\
\text { solution as the reference, the pH measured by your CPMS must be within the accuracy } \\
\text { specified in paragraph (e)(1) of this section"(MANDATORY). This requirement is } \\
\text { part of the testing and initial compliance requirements under the National Emission } \\
\text { Standards for Hazardous Air Pollutants for Refractory Products Manufacturing } \\
\text { (subpart) that form the National Emission Standards for Hazardous Air Pollutants for } \\
\text { Source Categories. }\end{array}$ & EPA & 40 CFR 63.9804(e)(3)(i) \\
\hline $\begin{array}{l}\text { NIST certified } \mathrm{pH} \\
\text { buffer solution }\end{array}$ & $\begin{array}{l}\text { This part of the regulation requires that an accuracy audit of the } \mathrm{pH} \text { CPMS be } \\
\text { conducted at least weekly "If your } \mathrm{pH} \text { CPMS does not include a redundant } \mathrm{pH} \text { sensor, } \\
\text { perform a single point calibration using an NIST-certified buffer solution that is } \\
\text { accurate to within } \pm 0.02 \mathrm{pH} \text { units at } 25^{\circ} \mathrm{C}\left(77^{\circ} \mathrm{F}\right) \text {. If the expected pH of the liquid } \\
\text { that is monitored lies in the acidic range (less than } 7 \mathrm{pH}) \text {, use a buffer solution with a } \\
\mathrm{pH} \text { value of } 4.00 \text {. If the expected } \mathrm{pH} \text { of the liquid that is monitored is neutral or lies in } \\
\text { the basic range (equal to or greater than } 7 \mathrm{pH}) \text {, use a buffer solution with a pH value of } \\
10.00 \text {. Place the electrode of the pH CPMS in the container of buffer solution. Record } \\
\text { the } \mathrm{pH} \text { measured by your CPMS. Using the certified buffer solution as the reference, } \\
\text { the } \mathrm{pH} \text { measured by your CPMS must be within the accuracy specified in paragraph } \\
\text { (e)(1) of this section" (MANDATORY). This requirement is part of the testing and } \\
\text { initial compliance requirements under the National Emission Standards for Hazardous } \\
\text { Air Pollutants for Refractory Products Manufacturing (subpart) that form the National } \\
\text { Emission Standards for Hazardous Air Pollutants for Source Categories. }\end{array}$ & EPA & 40 CFR 63.9804(e)(4)(ii) \\
\hline
\end{tabular}




\begin{tabular}{|c|c|c|c|}
\hline $\begin{array}{l}\text { calibration gas, } \\
\text { reference material }\end{array}$ & $\begin{array}{l}\text { Defines that "Calibration gas" means: } \\
\text { (1) A standard reference material; } \\
\text { (2) A standard reference material-equivalent compressed gas primary reference } \\
\text { material; } \\
\text { (3) A NIST traceable reference material; } \\
\text { (4) NIST/EPA-approved certified reference materials; } \\
\text { (5) A gas manufacturer's intermediate standard; } \\
\text { (6) An EPA protocol gas; } \\
\text { (7) Zero air material; or } \\
\text { (8) A research gas mixture. }\end{array}$ & EPA & 40 CFR 72.2 \\
\hline $\begin{array}{l}\text { reference material, } \\
\text { traceability }\end{array}$ & $\begin{array}{l}\text { States that "Gas manufacturer's intermediate standard (GMIS) means a compressed } \\
\text { gas calibration standard that has been assayed and certified by direct comparison to a } \\
\text { standard reference material (SRM), an SRM-equivalent PRM, a NIST/EPA-approved } \\
\text { certified reference material (CRM), or a NIST traceable reference material (NTRM), } \\
\text { in accordance with section 2.1.2.1 of the "EPA Traceability Protocol for Assay and } \\
\text { Certification of Gaseous Calibration Standards," September 1997, EPA-600/R- } \\
\text { 97/121." }\end{array}$ & EPA & 40 CFR 72.2 \\
\hline reference material & $\begin{array}{l}\text { Defines NIST/EPA-approved certified reference material or NIST/EPA-approved } \\
\text { CRM as "a calibration gas mixture that has been approved by EPA and the National } \\
\text { Institutes of Standards and Technologies (NIST) as having specific known chemical or } \\
\text { physical property values certified by a technically valid procedure as evidenced by a } \\
\text { certificate or other documentation issued by a certifying standard-setting body." }\end{array}$ & EPA & 40 CFR 72.2 \\
\hline reference material & $\begin{array}{l}\text { Defines NIST traceable reference material (NTRM) as "a calibration gas mixture } \\
\text { tested by and certified by the National Institutes of Standards and Technologies } \\
\text { (NIST) to have a certain specified concentration of gases. NTRMs may have different } \\
\text { concentrations from those of standard reference materials." }\end{array}$ & EPA & 40 CFR 72.2 \\
\hline Traceability & $\begin{array}{l}\text { Defines Research gas material (RGM) as "a calibration gas mixture developed by } \\
\text { agreement of a requestor and the National Institutes for Standards and Technologies } \\
\text { (NIST) that NIST analyzes and certifies as "NIST traceable." RGMs may have } \\
\text { concentrations different from those of standard reference materials." }\end{array}$ & EPA & 40 CFR 72.2 \\
\hline
\end{tabular}




\begin{tabular}{|c|c|c|c|}
\hline Traceability & $\begin{array}{l}\text { Defines Research gas mixture (RGM) as "a calibration gas mixture developed by } \\
\text { agreement of a requestor and NIST that NIST analyzes and certifies as "NIST } \\
\text { traceable." RGMs may have concentrations different from those of standard reference } \\
\text { materials." }\end{array}$ & EPA & 40 CFR 72.2 \\
\hline $\begin{array}{l}\text { NIST Traceable } \\
\text { equipment }\end{array}$ & $\begin{array}{l}\text { This regulation states that the operator shall record applicable information "..expected } \\
\text { transmitter output during accuracy test (reference value from NIST-traceable } \\
\text { equipment), including units of measure;..." as part of the record keeping requirements } \\
\text { for continuous emissions monitoring. }\end{array}$ & EPA & 40 CFR 75.59(b)(2)(iii) \\
\hline $\begin{array}{l}\text { NIST Traceability } \\
\text { certificates }\end{array}$ & $\begin{array}{l}\text { This regulation states that "the designated representative for an affected unit may } \\
\text { apply to the Administrator for an alternative to any standard incorporated by reference } \\
\text { and prescribed in this part. The designated representative shall include the following } \\
\text { information in an application..." "Information demonstrating that the proposed } \\
\text { alternative produces data acceptable for use in the Acid Rain Program, including } \\
\text { accuracy and precision statements, NIST traceability certificates or protocols, or other } \\
\text { supporting data, as applicable to the proposed alternative" in addition to other } \\
\text { information, as part of the reporting requirements for continuous emissions } \\
\text { monitoring. }\end{array}$ & EPA & 40 CFR 75.66(c)(3) \\
\hline $\begin{array}{l}\text { Traceability/Reference } \\
\text { Materials }\end{array}$ & $\begin{array}{l}\text { Reference is made to a NIST OU as a source of list of vendors and cylinder gases for } \\
\text { NIST traceable reference materials as part of the specifications and test procedures for } \\
\text { continuous emissions monitoring }\end{array}$ & EPA & $\begin{array}{l}\text { 40 CFR 75, Appendix A } \\
5.1 .3\end{array}$ \\
\hline Reference Materials & $\begin{array}{l}\text { Refers to a NIST OU for information about the "Research Gas Mixture (RGM) } \\
\text { program" as part of the specifications and test procedures for continuous emissions } \\
\text { monitoring }\end{array}$ & EPA & $\begin{array}{l}\text { 40 CFR 75, Appendix A } \\
5.1 .5\end{array}$ \\
\hline Reference Materials & $\begin{array}{l}\text { This regulation refers to NIST/EPA-Approved Certified Reference Materials stating } \\
\text { that existing certified reference materials (CRMs) that are still within their } \\
\text { certification period may be used as calibration gas as part of the specifications and test } \\
\text { procedures for continuous emissions monitoring }\end{array}$ & EPA & $\begin{array}{l}\text { 40 CFR 75, Appendix A } \\
\text { 5.1.7 }\end{array}$ \\
\hline $\begin{array}{l}\text { Traceability to NIST } \\
\text { standards }\end{array}$ & $\begin{array}{l}\text { This regulation refers to procedures in various standards to verify flowmeter accuracy. } \\
\text { It further states that the EPA "Administrator may also approve other procedures that } \\
\text { use equipment traceable to National Institute of Standards and Technology standards } \\
\text { ". This requirement is part of the initial certification requirements for all fuel } \\
\text { flowmeters when following optional SO2 emissions data protocol for gas-fired and } \\
\text { oil-fired units for continuous emissions monitoring. }\end{array}$ & EPA & $\begin{array}{l}40 \text { CFR 75, Appendix D } \\
\text { 2.1.5.1 }\end{array}$ \\
\hline
\end{tabular}




\begin{tabular}{|c|c|c|c|}
\hline $\begin{array}{l}\text { Traceability to NIST } \\
\text { standards }\end{array}$ & $\begin{array}{l}\text { Regulation states that while conducting transmitter or transducer accuracy tests for } \\
\text { orifice-, nozzle- and venturi- type flowmeters "Calibrate the differential pressure } \\
\text { transmitter or transducer, static pressure transmitter or transducer, and temperature } \\
\text { transmitter or transducer, as applicable, using equipment that has a current certificate } \\
\text { of traceability to NIST standards" (MANDATORY). This requirement is part of the } \\
\text { initial certification requirements for all fuel flowmeters when following optional SO2 } \\
\text { emissions data protocol for gas-fired and oil-fired units for continuous emissions } \\
\text { monitoring. }\end{array}$ & EPA & $\begin{array}{l}40 \text { CFR 75, Appendix D } \\
\text { 2.1.6.1(a) }\end{array}$ \\
\hline $\begin{array}{l}\text { NIST Traceable } \\
\text { reference value }\end{array}$ & $\begin{array}{l}\text { Regulation states that while conducting transmitter or transducer accuracy tests for } \\
\text { orifice-, nozzle- and venturi- type flowmeters he calibration of each transmitter or } \\
\text { transducer should be checked "by comparing its readings to that of the NIST traceable } \\
\text { equipment at least once at each of the following levels: the zero-level and at least two } \\
\text { other upscale levels (e.g., "mid" and "high"), such that the full range of transmitter or } \\
\text { transducer readings corresponding to normal unit operation is } \\
\text { represented .."(MANDATORY). This requirement is part of the initial certification } \\
\text { requirements for all fuel flowmeters when following optional SO2 emissions data } \\
\text { protocol for gas-fired and oil-fired units for continuous emissions monitoring. }\end{array}$ & EPA & $\begin{array}{l}40 \text { CFR 75, Appendix D } \\
2.1 .6 .1 \text { (a) }\end{array}$ \\
\hline $\begin{array}{l}\text { NIST Traceable } \\
\text { equipment }\end{array}$ & $\begin{array}{l}\text { This sub-section refers to the NIST traceable reference value for determination of the } \\
\text { accuracy of the transmitter or transducer as a percentage of the full scale, in the } \\
\text { equation used to determine the accuracy (MANDATORY). This requirement is part } \\
\text { of the initial certification requirements for all fuel flowmeters when following optional } \\
\text { SO2 emissions data protocol for gas-fired and oil-fired units for continuous emissions } \\
\text { monitoring. }\end{array}$ & EPA & $\begin{array}{l}40 \text { CFR 75, Appendix D } \\
2.1 .6 .1(\mathrm{~b})\end{array}$ \\
\hline $\begin{array}{l}\text { Reference to NIST } \\
\text { standard for statement } \\
\text { of accuracy }\end{array}$ & $\begin{array}{l}\text { Reference is made to a NBS lead in reference fuel to make a statement on the accuracy } \\
\text { of the measurement, as "The analysis of National Bureau of Standards (NBS) lead in } \\
\text { reference fuel of known concentrations in a single laboratory has resulted in found } \\
\text { values deviating from the true value for } 11 \text { determinations of } 0.0322 \mathrm{~g} \mathrm{~Pb} / \mathrm{gal} \text { by an } \\
\text { average of } 0.56 \% \text { with a standard deviation of } 6.8 \% \text {, for } 15 \text { determinations of } 0.0519 \mathrm{~g} \\
\mathrm{~Pb} / \mathrm{gal} \text { by an average of }-1.1 \% \text { with a standard deviation of } 5.8 \% \text {, and for } 7 \\
\text { determinations of } 0.0725 \mathrm{~g} \mathrm{~Pb} / \mathrm{gal} \text { by an average of } 3.5 \% \text { with a standard deviation of } \\
4.8 \% " \text {. This statement applies to automated method test for determination of lead in } \\
\text { gasoline by Atomic Absorption Spectrometry, as part of the regulations for fuels and } \\
\text { fuel additives. }\end{array}$ & EPA & $\begin{array}{l}\text { 40 CFR } 80 \text { - Appendix B } \\
\text { (Subpart J); Method 2, } \\
10.2 .1\end{array}$ \\
\hline $\begin{array}{l}\text { NBS Lead-in-reference } \\
\text { fuel standard }\end{array}$ & $\begin{array}{l}\text { This regulation stipulates that the suitability of a calibration curve used in the test } \\
\text { procedure for testing of lead in gasoline by X-ray spectrometry should be checked } \\
\text { each day "by analyzing several National Bureau of Standards (NBS) lead-in-reference- } \\
\text { fuel standards or other suitable standards". }\end{array}$ & EPA & $\begin{array}{l}40 \text { CFR } 80 \text { - Appendix B } \\
\text { (Subpart J); Method 3, } 7.1\end{array}$ \\
\hline
\end{tabular}

Appendix 5 


\begin{tabular}{|c|c|c|c|c|}
\hline $\begin{array}{l}\text { NBS Lead-in-reference } \\
\text { fuel standard }\end{array}$ & $\begin{array}{l}\text { It is required that "quality control standards, such as NBS standard reference } \\
\text { materials, should be analyzed at least once every testing session" when testing of lead } \\
\text { in gasoline by X-ray spectrometry (MANDATORY). }\end{array}$ & & EPA & $\begin{array}{l}40 \text { CFR } 80 \text { - Appendix B } \\
\text { (Subpart J); Method 3, } 7.4\end{array}$ \\
\hline $\begin{array}{l}\text { Traceability to NBS } \\
\text { Standard }\end{array}$ & $\begin{array}{l}\text { This regulation states that span gases used in weekly checks of analyzers used as part } \\
\text { of emission control system performance warranty short tests, "shall be traceable to } \\
\text { NBS standards } \pm 2 \% \text { and have" in addition to other requirements for concentration } \\
\text { (MANDATORY). This regulation is a subpart of testing for control of air pollution } \\
\text { from mobile sources. This regulation further stipulates that "requirements of } \S 85.2233 \\
\text { apply concurrently until December } 31,1993 \text {, after which the requirements of } \S 85.2233 \\
\text { are solely in effect". }\end{array}$ & & EPA & 40 CFR 85.2232(e)(4) \\
\hline $\begin{array}{l}\text { Traceability to NBS } \\
\text { Standard }\end{array}$ & $\begin{array}{l}\text { This regulation specifies the requirements for span gases for gas calibration conducted } \\
\text { as part of the steady state test equipment calibrations, adjustment and quality control } \\
\text { conducted in emission control systems performance warranty short tests for control of } \\
\text { air pollution from mobile sources. This regulation states that in addition to other } \\
\text { requirements, span gases "must be traceable to National Institute of Standards and } \\
\text { Technology (NIST) standards within two percent" (MANDATORY). }\end{array}$ & 1994 & EPA & 40 CFR 85.2233(e)(3) \\
\hline $\begin{array}{l}\text { Traceability to NIST } \\
\text { standard }\end{array}$ & $\begin{array}{l}\text { Calibration gases- States that calibration gases used in test procedures for Emission } \\
\text { Regulations for } 1977 \text { and Later Model Year (in this case from } 1979 \text { onwards, till } \\
\text { superseded) New Light-Duty Vehicles and New Light-Duty Trucks and New Otto- } \\
\text { Cycle Complete Heavy-Duty Vehicles "shall be traceable to within } 1 \text { percent of NBS } \\
\text { gas standards, or other gas standards which have been approved by the Administrator." }\end{array}$ & & EPA & 40 CFR 86.114-79 (b) \\
\hline NIST Gas Standards & $\begin{array}{l}\text { Span gases- States that Span gases used in test procedures for Emission Regulations } \\
\text { for } 1977 \text { and Later Model Year (in this case from } 1979 \text { onwards, till superseded) New } \\
\text { Light-Duty Vehicles and New Light-Duty Trucks and New Otto-Cycle Complete } \\
\text { Heavy-Duty Vehicles " shall be accurate to within } 2 \text { percent of true concentration, } \\
\text { where true concentration refers to NBS gas standards, or other gas standards which } \\
\text { have been approved by the Administrator". }\end{array}$ & & EPA & 41 CFR 86.114-79 (c) \\
\hline $\begin{array}{l}\text { Traceability NIST } \\
\text { standards }\end{array}$ & $\begin{array}{l}\text { Methanol in air gases- states that methanol in air gases used for response factor } \\
\text { determination in test procedures for Emission Regulations for } 1977 \text { and Later Model } \\
\text { Year (in this case from } 1994 \text { onwards, till superseded) New Light-Duty Vehicles and } \\
\text { New Light-Duty Trucks and New Otto-Cycle Complete Heavy-Duty Vehicles "shall } \\
\text { be traceable to within } \pm 2 \text { percent of NIST (formerly NBS) gas standards, or other } \\
\text { standards which have been approved by the Administrator" (MANDATORY). }\end{array}$ & & EPA & 40 CFR 86.114-94(d)(1) \\
\hline $\begin{array}{l}\text { Traceability to NIST } \\
\text { standard }\end{array}$ & $\begin{array}{l}\text { Calibration gases- States that calibration gases (except for methanol )used in test } \\
\text { procedures for Emission Regulations for } 1977 \text { and Later Model Year (in this case from } \\
1994 \text { onwards, till superseded) New Light-Duty Vehicles and New Light-Duty Trucks } \\
\text { and New Otto-Cycle Complete Heavy-Duty Vehicles "shall be traceable to within } 1 \\
\text { percent of NIST (formerly NBS) gas standards, or other gas standards which have } \\
\text { been approved by the Administrator." }\end{array}$ & & EPA & 40 CFR 86.114-94(b) \\
\hline
\end{tabular}

Appendix 5 


\begin{tabular}{|c|c|c|c|}
\hline NIST Gas Standards & $\begin{array}{l}\text { Span gases -States that Span gases (not including methanol) used in test procedures } \\
\text { for Emission Regulations for } 1977 \text { and Later Model Year (in this case from } 1994 \\
\text { onwards, till superseded) New Light-Duty Vehicles and New Light-Duty Trucks and } \\
\text { New Otto-Cycle Complete Heavy-Duty Vehicles " shall be accurate to within two } \\
\text { percent of true concentration, where true concentration refers to NIST (formerly NBS) } \\
\text { gas standards, or other gas standards which have been approved by the Administrator." }\end{array}$ & EPA & 40 CFR 86.114-94(c) \\
\hline $\begin{array}{l}\text { Traceability to NBS } \\
\text { flow calibration device }\end{array}$ & $\begin{array}{l}\text { Flow calibration device-States that test procedures for gas meter or flow } \\
\text { instrumentation calibration for particulate, methanol and formaldehyde measurement } \\
\text { as part of testing for Emission Regulations for } 1977 \text { and Later Model Year (in this } \\
\text { case } 1994 \text { onwards, till superseded) New Light-Duty Vehicles and New Light-Duty } \\
\text { Trucks and New Otto-Cycle Complete Heavy-Duty Vehicles require that "a } \\
\text { calibration device be installed in series with the instrument. A critical flow orifice, a } \\
\text { bellmouth nozzle, a laminar flow element or an NBS traceable flow calibration device } \\
\text { is required as the standard device". }\end{array}$ & EPA & $\begin{array}{l}40 \text { CFR 86.120- } \\
\text { 94(a)(1)(i) }\end{array}$ \\
\hline Traceability & $\begin{array}{l}\text { known methane in air concentrations - States that "to determine the total hydrocarbon } \\
\text { FID response to methane, known methane in air concentrations traceable to the } \\
\text { National Institute of Standards and Technology (NIST) shall be analyzed by the FID"- } \\
\text { flame ionization detector, as part of the procedure for hydrocarbon analyzer } \\
\text { calibration defined as test procedures for Emission Regulations for } 1977 \text { and Later } \\
\text { Model Year (in this case } 1990 \text { onwards, till superseded) New Light-Duty Vehicles and } \\
\text { New Light-Duty Trucks and New Otto-Cycle Complete Heavy-Duty Vehicles } \\
\text { (MANDATORY) }\end{array}$ & EPA & 40 CFR 86.121-90(d) \\
\hline $\begin{array}{l}\text { Traceability / NBS } \\
\text { Standards }\end{array}$ & $\begin{array}{l}\text { NBS weights -states that for calibrating dynamometers as part of the Dynamometer } \\
\text { and Engine Equipment Specification for Emission Regulations for New (model year } \\
1979 \text { and later) Gasoline-Fueled and Diesel-Fueled Heavy-Duty Engines; Gaseous } \\
\text { Exhaust Test Procedures "a minimum of } 6 \text { calibration weights for each range used are } \\
\text { required. The weights must be equally spaced and traceable to within } 0.5 \text { percent of } \\
\text { NBS weights. Laboratories located in foreign countries may certify calibration weights } \\
\text { to local government bureau standards" (MANDATORY) }\end{array}$ & EPA & 40 CFR 86.312-79(a)(2) \\
\hline $\begin{array}{l}\text { Traceability to NBS } \\
\text { standards }\end{array}$ & $\begin{array}{l}\text { NBS weights -provides the option that a master load-cell or transfer standard may be } \\
\text { used to verify the in-use torque measurement system as part of the dynamometer } \\
\text { calibration procedure for Gaseous Exhaust Test Procedures prescribed for Emission } \\
\text { Regulations for New (in this case } 1979 \text { and later) Gasoline-Fueled and Diesel-Fueled } \\
\text { Heavy-Duty Engines. However, it is further stated "that the master load-cell and read } \\
\text { out system must be calibrated with weights at each test weight specified in } \S 86.312- \\
79 \text { and that the calibration weights must be traceable to within } 0.1 \text { percent of NBS } \\
\text { weights" }\end{array}$ & EPA & 40 CFR 86.333 .79 (c)(1) \\
\hline
\end{tabular}




\begin{tabular}{|c|c|c|c|}
\hline $\begin{array}{l}\text { Traceability to NIST } \\
\text { standard }\end{array}$ & $\begin{array}{l}\text { Analytical Gases - states that "Methanol in air gases used for response factor } \\
\text { determination shall be traceable to within } \pm 2 \text { percent of NIST (formerly NBS) gas } \\
\text { standards, or other gas standards which have been approved by the Administrator" for } \\
\text { test procedures used in Emission Regulations for } 1978 \text { and Later New Motorcycles, as } \\
\text { part of testing for control of emissions from new and in-use highway vehicles and } \\
\text { engines. }\end{array}$ & EPA & 40 CFR $86.514-78(c)(1)$ \\
\hline Traceability & $\begin{array}{l}\text { known methane in air concentrations -"FID response factor to methane"- States that } \\
\text { "when the FID analyzer is to be used for the analysis of natural gas-fueled motorcycle } \\
\text { hydrocarbon samples, the methane response factor of the analyzer shall be established. } \\
\text { To determine the total hydrocarbon FID response to methane, known methane in air } \\
\text { concentrations traceable to National Institute of Standards and Technology (NIST) } \\
\text { shall be analyzed by the FID. Several methane concentrations shall be analyzed by the } \\
\text { FID in the range of concentrations in the exhaust sample." This is required for } \\
\text { calibration of hydrocarbon analyzers used in test procedures for Emission Regulations } \\
\text { for } 1978 \text { (in this case } 1990 \text { onwards) and Later New Motorcycles as part of control of } \\
\text { emissions from new and in-use highway vehicles and engines. }\end{array}$ & EPA & 40 CFR 86.521-90 (e) \\
\hline $\begin{array}{l}\text { NBS Reference } \\
\text { standards (optical } \\
\text { filters)/Calibration }\end{array}$ & $\begin{array}{l}\text { reference filters- requires that filters used for checking linearity of smokemeters used } \\
\text { in Smoke Exhaust Test Procedures in testing for Emission Regulations for New Diesel } \\
\text { Heavy-Duty Engines be checked for opacity annually using NBS or equivalent } \\
\text { reference filters. This requirement is part of testing for control of emissions from new } \\
\text { and in-use highway vehicles and engines. }\end{array}$ & EPA & 40 CFR 86.884-11(3) \\
\hline $\begin{array}{l}\text { Traceability to NIST } \\
\text { standard }\end{array}$ & $\begin{array}{l}\text { Calibration Gases- States that calibration gases (not including methanol) used in an } \\
\text { hydrocarbon analyzer in Evaporative Emission Test Procedures for New (in this case } \\
1985 \text { and newer, until superseded) Gasoline-Fueled, Natural Gas- Fueled, Liquefied } \\
\text { Petroleum Gas-Fueled and Methanol-Fueled Heavy-Duty Vehicles "shall be traceable } \\
\text { to within one percent of NIST (formerly NBS) gas standards, or other gas standards } \\
\text { which have been approved by the Administrator". This requirement is defined for } \\
\text { control of emissions from new and in-use highway vehicles and engines. }\end{array}$ & EPA & 40 CFR 86.1214-85(b) \\
\hline $\begin{array}{l}\text { Traceability to } \\
\text { NIST Gas Standards }\end{array}$ & $\begin{array}{l}\text { Span Gases - States that Span gases (not including methanol) used in an hydrocarbon } \\
\text { analyzer in Evaporative Emission Test Procedures for New (in this case } 1985 \text { and } \\
\text { newer, until superseded)Gasoline-Fueled, Natural Gas- Fueled, Liquefied Petroleum } \\
\text { Gas-Fueled and Methanol-Fueled Heavy-Duty Vehicles "shall be accurate to within } \\
\text { two percent of true concentration, where true concentration refers to NIST (formerly } \\
\text { NBS) gas standards, or other gas standards which have been approved by the } \\
\text { Administrator." This requirement is defined for control of emissions from new and in- } \\
\text { use highway vehicles and engines. }\end{array}$ & EPA & 40 CFR 86.1214-85 (c) \\
\hline
\end{tabular}




\begin{tabular}{|c|c|c|c|}
\hline $\begin{array}{l}\text { Traceability to NIST } \\
\text { gas standard }\end{array}$ & $\begin{array}{l}\text { Methanol in air gases- States that Methanol in air gases used for response factor } \\
\text { determination in hydrocarbon analyzers in Evaporative Emission Test Procedures for } \\
\text { New (in this case } 1985 \text { and newer, until superseded) Gasoline-Fueled, Natural Gas- } \\
\text { Fueled, Liquefied Petroleum Gas-Fueled and Methanol-Fueled Heavy-Duty Vehicles } \\
\text { shall be traceable to within } \pm 2 \text { percent of NIST (formerly NBS) gas standards, or other } \\
\text { gas standards which have been approved by the Administrator." This requirement is } \\
\text { defined for control of emissions from new and in-use highway vehicles and engines. }\end{array}$ & EPA & $\begin{array}{l}40 \text { CFR } 86.1214-85 \\
\text { (d)(2) }\end{array}$ \\
\hline Traceability & $\begin{array}{l}\text { FID Response Factor Methane -States that "When the FID analyzer to be used for the } \\
\text { analysis of natural gas-fueled vehicle hydrocarbon samples has been calibrated using } \\
\text { propane, the methane response factor of the analyzer shall be established. To } \\
\text { determine the total hydrocarbon FID response to methane, known methane in air } \\
\text { concentrations traceable to National Institute of Standards and Technology (NIST) } \\
\text { shall be analyzed by the FID. " This is required for calibration of hydrocarbon } \\
\text { analyzers used in Evaporative Emission Test Procedures for New (in this case, } 1990 \\
\text { and newer until superseded) Gasoline-Fueled, Natural Gas- Fueled, Liquefied } \\
\text { Petroleum Gas-Fueled and Methanol-Fueled Heavy-Duty Vehicles as part of control } \\
\text { of emissions from new and in-use highway vehicles and engines. }\end{array}$ & EPA & 40 CFR 86.1221-90 (e) \\
\hline $\begin{array}{l}\text { NIST Traceable } \\
\text { standards for calibration }\end{array}$ & $\begin{array}{l}\text { Calibration- This regulation states that an application for approval of an alternate test } \\
\text { system that would consistently and reliably produce emission test results that are at } \\
\text { least equivalent to those described in 40CFR 86.1306-07 (Emission Regulations for } \\
\text { New Otto-Cycle and Diesel Heavy-Duty Engines; Gaseous and Particulate Exhaust } \\
\text { Test Procedures) should include a section that "shall describe all of the installation, } \\
\text { calibration, operation, and maintenance procedures in a step-by-step format. Note that } \\
\text { empirical calibration with respect to another prescribed or approved measurement } \\
\text { system is not acceptable. Calibration should be performed with NIST traceable } \\
\text { standards, or equivalent national standards". }\end{array}$ & EPA & $\begin{array}{l}\text { 40 CFR 86.1306- } \\
07(d)(5)(\mathrm{iii})\end{array}$ \\
\hline $\begin{array}{l}\text { NIST Traceable } \\
\text { standards for calibration }\end{array}$ & $\begin{array}{l}\text { Calibration- This regulation states that for an application for approval of an alternate } \\
\text { test system that would consistently and reliably produce emission test results that are } \\
\text { at least equivalent to those described in 40CFR 86.1306-07 (Emission Regulations for } \\
\text { New Otto-Cycle and Diesel Heavy-Duty Engines; Gaseous and Particulate Exhaust } \\
\text { Test Procedures) comparison of results from the alternate system and from the } \\
\text { prescribed system (or other system approved by the Administrator) need to be } \\
\text { included. "The two systems must be calibrated independently to NIST traceable } \\
\text { standards or equivalent national standards for this comparison."....... }\end{array}$ & EPA & $\begin{array}{l}\text { 40 CFR 86.1306- } \\
07(d)(5)(i v)\end{array}$ \\
\hline $\begin{array}{l}\text { Traceability / } \\
\text { calibration - NBS "true" } \\
\text { value }\end{array}$ & $\begin{array}{l}\text { Reference is part of the dynamometer and engine equipment specification for gaseous } \\
\text { and particulate exhaust test procedures used in emission regulations for new (in this } \\
\text { case } 1984 \text { and newer, until superseded) Otto cycle and diesel heavy-duty engines as } \\
\text { part of testing for control of emissions from new and in-use highway vehicles and } \\
\text { engines. Requires that "Engine flywheel torque readout shall be accurate to within } \pm 3 \\
\text { percent of the NBS "true" value torque", or certain other defined accuracies. }\end{array}$ & EPA & 40 CFR 86.1308-84 (a)(2) \\
\hline
\end{tabular}

Appendix 5 


\begin{tabular}{|c|c|c|c|}
\hline $\begin{array}{l}\text { Traceability / } \\
\text { calibration - NBS "true" } \\
\text { value }\end{array}$ & $\begin{array}{l}\text { Reference is part of the dynamometer and engine equipment specification for gaseous } \\
\text { and particulate exhaust test procedures used in emission regulations for new (in this } \\
\text { case } 1984 \text { and newer, until superseded) Otto cycle and diesel heavy-duty engines as } \\
\text { part of testing for control of emissions from new and in-use highway vehicles and } \\
\text { engines. States that "Engine flywheel torque values used for cycle evaluation shall be } \\
\text { accurate to within } \pm 3.6 \text { percent of NBS "true" values...." to provide a more convenient } \\
\text { option for the test procedures. }\end{array}$ & & 40 CFR $86.1308-84$ (c)(2) \\
\hline Traceability & $\begin{array}{l}\text { Weights traceable to NIST - Refers to NBS traceable weights to define to define the } \\
\text { NBS "true" value torque referred to in } 41 \text { CFR } 86.1308-84 \text { para (a)(2) and para (c)(2). }\end{array}$ & EPA & 40 CFR 86.1308-84 (e) \\
\hline $\begin{array}{l}\text { Traceability to NBS } \\
\text { weight standards }\end{array}$ & $\begin{array}{l}\text { Requires that calibration weights used for each range of torque measuring device be } \\
\text { "traceable to NBS weights" in dynamometer and engine equipment specification for } \\
\text { gaseous and particulate exhaust test procedures used in emission regulations for new } \\
\text { (in this case } 1984 \text { and newer, until superseded) Otto cycle and diesel heavy-duty } \\
\text { engines as part of testing for control of emissions from new and in-use highway } \\
\text { vehicles and engines. }\end{array}$ & EPA & $\begin{array}{l}\text { 40CFR } 86.1308-84 \\
\text { (e)(1)(i) }\end{array}$ \\
\hline Traceability to NIST & $\begin{array}{l}\text { Requires that "dewpoint shall be measured with an instrument that exhibits an } \\
\text { accuracy of at least } \pm 0.25^{\circ} \mathrm{C} \text { NIST traceable as stated by the instrument manufacturer" } \\
\text { for establishing ambient conditions for filter stabilization and weighing; as a } \\
\text { requirement for Filter stabilization and microbalance workstation environmental } \\
\text { conditions, microbalance specifications, and particulate matter filter handling and } \\
\text { weighing procedures as part of the gaseous and particulate exhaust test procedures for } \\
\text { emission regulations for new Otto-Cycle and Diesel heavy-duty engines. }\end{array}$ & EPA & $\begin{array}{l}\text { 40 CFR 86.1312- } \\
\text { 2007(a)(1)(i) }\end{array}$ \\
\hline Traceability to NIST & $\begin{array}{l}\text { Requires that "dewpoint shall be measured with an instrument that exhibits an } \\
\text { accuracy of at least } \pm 0.25^{\circ} \mathrm{C} \text { NIST traceable as stated by the instrument manufacturer" } \\
\text { for verifying the immediate microbalance work environment; as a requirement for } \\
\text { Filter stabilization and microbalance workstation environmental conditions, } \\
\text { microbalance specifications, and particulate matter filter handling and weighing } \\
\text { procedures as part of the gaseous and particulate exhaust test procedures for emission } \\
\text { regulations for new Otto-Cycle and Diesel heavy-duty engines. }\end{array}$ & EPA & $\begin{array}{l}\text { 40 CFR 86.1312- } \\
\text { 2007(a)(1)(ii) }\end{array}$ \\
\hline Traceability/calibration & $\begin{array}{l}\text { certification and calibration procedures - Specifications for microbalances used for } \\
\text { determination of the weight of filters requires that "all certification and calibration } \\
\text { procedures shall be NIST traceable, or traceable to an equivalent national standard"; as } \\
\text { a requirement for Filter stabilization and microbalance workstation environmental } \\
\text { conditions, microbalance specifications, and particulate matter filter handling and } \\
\text { weighing procedures as part of the gaseous and particulate exhaust test procedures for } \\
\text { emission regulations for new Otto-Cycle and Diesel heavy-duty engines. }\end{array}$ & EPA & 40 CFR 86.1312-2007(b) \\
\hline
\end{tabular}

Appendix 5 


\begin{tabular}{|c|c|c|c|}
\hline $\begin{array}{l}\text { Traceability to NBS gas } \\
\text { standards }\end{array}$ & $\begin{array}{l}\text { Calibration gases - Requires that calibration gases used in gas analyzers for gaseous } \\
\text { and particulate exhaust test procedures used in emission regulations for new (in this } \\
\text { case } 1984 \text { and newer, until superseded) Otto cycle and diesel heavy-duty engines as } \\
\text { part of testing for control of emissions from new and in-use highway vehicles and } \\
\text { engines "shall be accurate to within } \pm 1 \text { percent of NBS gas standards, or other gas } \\
\text { standards which have been approved by the Administrator" }\end{array}$ & EPA & $\begin{array}{l}40 \text { CFR } 86.1314-84 \\
\text { (f))(2) }\end{array}$ \\
\hline $\begin{array}{l}\text { Traceability to NBS gas } \\
\text { standards }\end{array}$ & $\begin{array}{l}\text { Span Gases - Requires that span gases used in gas analyzers for gaseous and } \\
\text { particulate exhaust test procedures used in emission regulations for new (in this case } \\
1984 \text { and newer, until superseded) Otto cycle and diesel heavy-duty engines as part of } \\
\text { testing for control of emissions from new and in-use highway vehicles and engines } \\
\text { "shall be accurate to within } \pm 2 \text { percent of NBS gas standards, or other gas standards } \\
\text { which have been approved by the Administrator" }\end{array}$ & EPA & 40 CFR 86.1314-84(f)(3) \\
\hline $\begin{array}{l}\text { Traceability to NBS gas } \\
\text { standards }\end{array}$ & $\begin{array}{l}\text { States that "the use of precision blending devices (gas dividers) to obtain the required } \\
\text { calibration gas concentrations is acceptable, provided that the blended gases are } \\
\text { accurate to within } \pm 1.5 \text { percent of NBS gas standards, or other gas standards which } \\
\text { have been approved by the Administrator. This accuracy implies that primary gases } \\
\text { used for blending must be "named" to an accuracy of at least } \pm 1 \text { percent, traceable to } \\
\text { NBS or other approved gas standards." This is for use in gas analyzers for gaseous and } \\
\text { particulate exhaust test procedures used in emission regulations for new (in this case } \\
1984 \text { and newer, until superseded) Otto cycle and diesel heavy-duty engines as part of } \\
\text { testing for control of emissions from new and in-use highway vehicles and engines }\end{array}$ & EPA & 40 CFR 86.1314-84 (g) \\
\hline $\begin{array}{l}\text { Traceability to NIST } \\
\text { gas standard }\end{array}$ & $\begin{array}{l}\text { Calibration gases -Requires that calibration gases used in gas analyzers for gaseous } \\
\text { and particulate exhaust test procedures used in emission regulations for new (in this } \\
\text { case } 1994 \text { and newer, until superseded) Otto cycle and diesel heavy-duty engines as } \\
\text { part of testing for control of emissions from new and in-use highway vehicles and } \\
\text { engines (not including methanol) shall be traceable to within one percent of NIST } \\
\text { (formerly NBS) gas standards, or other gas standards which have been approved by } \\
\text { the Administrator. }\end{array}$ & EPA & 40 CFR 86.1314-94(g)(2) \\
\hline $\begin{array}{l}\text { Traceability to NIST } \\
\text { gas standard }\end{array}$ & $\begin{array}{l}\text { Span gases - Requires that span gases (not including methanol) used in gas analyzers } \\
\text { for gaseous and particulate exhaust test procedures used in emission regulations for } \\
\text { new (in this case } 1994 \text { and newer, until superseded) Otto cycle and diesel heavy-duty } \\
\text { engines as part of testing for control of emissions from new and in-use highway } \\
\text { vehicles and engines "shall be accurate to within two percent of true concentration, } \\
\text { where true concentration refers to NIST (formerly NBS) gas standards, or other gas } \\
\text { standards which have been approved by the Administrator." }\end{array}$ & EPA & 40 CFR 86.1314-94(g)(3) \\
\hline
\end{tabular}




\begin{tabular}{|c|c|c|c|}
\hline Traceability & $\begin{array}{l}\text { Methanol in air gases - Requires that Methanol in air gases used for response factor } \\
\text { determination shall be traceable to within } \pm 2 \text { percent of NIST (formerly NBS) gas } \\
\text { standards, or other standards which have been approved by the Administrator" as part } \\
\text { of the gaseous and particulate exhaust test procedures used in emission regulations for } \\
\text { new (in this case } 1994 \text { and newer, until superseded) Otto cycle and diesel heavy-duty } \\
\text { engines in testing for control of emissions from new and in-use highway vehicles and } \\
\text { engines. }\end{array}$ & EPA & $\begin{array}{l}40 \text { CFR 86.1314- } \\
94(\mathrm{~g})(4)(\mathrm{i})\end{array}$ \\
\hline $\begin{array}{l}\text { Traceability to } \\
\text { NIST/NBS gas } \\
\text { standards }\end{array}$ & $\begin{array}{l}\text { known methane in air concentrations - States that "the use of precision blending } \\
\text { devices (gas dividers) to obtain the required calibration gas concentrations is } \\
\text { acceptable, provided that the blended gases are accurate to within } \pm 1.5 \text { percent of NBS } \\
\text { gas standards, or other gas standards which have been approved by the Administrator. } \\
\text { This accuracy implies that primary gases used for blending must be "named" to an } \\
\text { accuracy of at least } \pm 1 \text { percent, traceable to NBS or other approved gas standards". } \\
\text { This is a part of the requirements for gaseous and particulate exhaust test procedures } \\
\text { used in emission regulations for new (in this case } 1994 \text { and newer, until superseded) } \\
\text { Otto cycle and diesel heavy-duty engines in testing for control of emissions from new } \\
\text { and in-use highway vehicles and engines. }\end{array}$ & EPA & 40 CFR 86.1314-94 \\
\hline $\begin{array}{l}\text { Traceability to } \\
\text { NBS/calibration }\end{array}$ & $\begin{array}{l}\text { CVS calibration - requires that "the CVS is calibrated using an accurate flowmeter and } \\
\text { restrictor valve. The flowmeter calibration shall be traceable to the NBS, and will } \\
\text { serve as the reference value (NBS "true" value) for the CVS calibration. (Note: In no } \\
\text { case should an upstream screen or other restriction which can affect the flow be used } \\
\text { ahead of the flowmeter unless calibrated throughout the flow range with such a } \\
\text { device.) The CVS calibration procedures are designed for use of a "metering venturi" } \\
\text { type flowmeter. Large radius or ASME flow nozzles are considered equivalent if } \\
\text { traceable to NBS measurements. Other measurement systems may be used if shown to } \\
\text { be equivalent under the test conditions in this action and traceable to NBS } \\
\text { measurements." This is a part of the requirements for gaseous and particulate exhaust } \\
\text { test procedures used in emission regulations for new (in this case } 1984 \text { and later, until } \\
\text { superseded) Otto cycle and diesel heavy-duty engines in testing for control of } \\
\text { emissions from new and in-use highway vehicles and engines. }\end{array}$ & EPA & 40 CFR 86.1319-84(a) \\
\hline Traceability & $\begin{array}{l}\text { Requires that air flow sensor read out tolerances for calibration data measurements } \\
\text { must be } \pm 0.5 \% \text { of NBS "true" value. (MANDATORY if this technique is used). This } \\
\text { measurement is part of the PDP calibration is one of the required measurements that } \\
\text { establishes flow rate of the CVS pump. This is a part of the requirements for gaseous } \\
\text { and particulate exhaust test procedures used in emission regulations for new (in this } \\
\text { case } 1984 \text { and later, until superseded) Otto cycle and diesel heavy-duty engines in } \\
\text { testing for control of emissions from new and in-use highway vehicles and engines. }\end{array}$ & & 40 CFR 86.1319-84(c)(4) \\
\hline
\end{tabular}




\begin{tabular}{|c|c|c|c|}
\hline $\begin{array}{l}\text { Traceability / } \\
\text { calibration }\end{array}$ & $\begin{array}{l}\text { CVS calibration - requires that "the CVS is calibrated using an accurate flowmeter and } \\
\text { restrictor valve. The flowmeter calibration shall be traceable to the NBS, and will } \\
\text { serve as the reference value (NBS "true" value) for the CVS calibration. The CVS } \\
\text { calibration procedures are designed for use of a "metering venturi" type flowmeter. } \\
\text { Large radius or ASME flow nozzles are considered equivalent if traceable to NBS } \\
\text { measurements. Other measurement systems may be used if shown to be equivalent } \\
\text { under the test conditions in this section and traceable to NBS measurements. } \\
\text { Measurements of the various flowmeter parameters are recorded and related to flow } \\
\text { through the CVS. Procedures used by EPA for both PDP-CVS and CFV-CVS are } \\
\text { outlined below. Other procedures yielding equivalent results may be used if approved } \\
\text { in advance by the Administrator". This is a part of the requirements for gaseous and } \\
\text { particulate exhaust test procedures used in emission regulations for new (in this case } \\
1990 \text { and later, until superseded) Otto cycle and diesel heavy-duty engines in testing } \\
\text { for control of emissions from new and in-use highway vehicles and engines. }\end{array}$ & EPA & 40 CFR 86.1319-90(a) \\
\hline $\begin{array}{l}\text { Traceability / } \\
\text { calibration }\end{array}$ & $\begin{array}{l}\text { Requires that air flow sensor read out tolerances for calibration data measurements } \\
\text { must be } \pm 0.5 \% \text { of NBS "true" value. (MANDATORY if this technique is used). This } \\
\text { measurement is part of the PDP calibration is one of the required measurements that } \\
\text { establishes flow rate of the CVS pump. This is a part of the requirements for gaseous } \\
\text { and particulate exhaust test procedures used in emission regulations for new (in this } \\
\text { case } 1990 \text { and later, until superseded) Otto cycle and diesel heavy-duty engines in } \\
\text { testing for control of emissions from new and in-use highway vehicles and engines. }\end{array}$ & EPA & 40 CFR 86.1319-90(c)(4) \\
\hline Traceability & $\begin{array}{l}\text { Requires that air flow sensor read out tolerances for flow calibration measurements } \\
\text { must be } \pm 0.5 \% \text { of NBS "true" value. (MANDATORY). This measurement is part of } \\
\text { the CFV calibration is one of the required measurements that establishes the value of } \\
\text { the calibration coefficient at measured values of pressure, temperature and air flow. } \\
\text { This is a part of the requirements for gaseous and particulate exhaust test procedures } \\
\text { used in emission regulations for new (in this case } 1990 \text { and later, until superseded) } \\
\text { Otto cycle and diesel heavy-duty engines in testing for control of emissions from new } \\
\text { and in-use highway vehicles and engines. }\end{array}$ & & 40 CFR 86.1319-90(d)(3) \\
\hline $\begin{array}{l}\text { Traceability / } \\
\text { calibration }\end{array}$ & $\begin{array}{l}\text { NBS traceable flow calibration- Requires the use of gas meters or flow } \\
\text { instrumentation to determine flow through the particulate filters, methanol impingers } \\
\text { and formaldehyde impingers while sampling for particulate, methanol and } \\
\text { formaldehyde emissions as part of Gaseous and Particulate Exhaust Test Procedures } \\
\text { for Emission Regulations for New (in this case } 1990 \text { and later, until superseded) Otto- } \\
\text { Cycle and Diesel Heavy-Duty Engines. The regulation states that the instruments } \\
\text { shall be calibrated initially and periodically by installing a "calibration device in series } \\
\text { with the instrument. A critical flow orifice, a bellmouth nozzle, or a laminar flow } \\
\text { element or an NBS traceable flow calibration device is required as the standard } \\
\text { device". This regulation covers testing for control of emissions from new and in-use } \\
\text { highway vehicles and engines. }\end{array}$ & EPA & $\begin{array}{l}40 \text { CFR } 86.1320-90 \\
\text { (a)(1)(i) }\end{array}$ \\
\hline
\end{tabular}

Appendix 5 


\begin{tabular}{|c|c|c|c|}
\hline Traceability & $\begin{array}{l}\text { known methane in air concentrations - States that "when the FID analyzer is to be used } \\
\text { for the analysis of natural gas-fueled vehicle hydrocarbon samples, the methane } \\
\text { response factor of the analyzer shall be established. To determine the total } \\
\text { hydrocarbon FID response to methane, known methane in air concentrations traceable } \\
\text { to National Institute of Standards and Technology (NIST) shall be analyzed by the } \\
\text { FID" (MANDATORY). This is required for calibration of the hydrocarbon analyzer } \\
\text { for gaseous and particulate exhaust test procedures used for emission regulations for } \\
\text { new Otto-Cycle and diesel heavy-duty engines used for control of emissions from new } \\
\text { and in-use highway vehicles and engines. }\end{array}$ & EPA & 40 CFR 86.1321-94(d) \\
\hline Traceability & $\begin{array}{l}\text { Dynamometer specifications and calibration weights as stated under Emission Test } \\
\text { Equipment Provisions for control of emissions from new and in-use nonroad } \\
\text { compression-ignition engines require that "a minimum of six calibration weights for } \\
\text { each range used are required. The weights must be spaced to reflect good engineering } \\
\text { judgment such that they cover the range of weights required and must be traceable to } \\
\text { within } 0.5 \text { percent of NIST weights. Laboratories located in foreign countries may } \\
\text { certify calibration weights to local government bureau standards." }\end{array}$ & EPA & 40 CFR 89.306(b) \\
\hline Traceability/calibration & $\begin{array}{l}\text { Requires that "calibration gas values are to be derived from NIST Standard Reference } \\
\text { Materials (SRMs) or other standardized gas samples...". This requirement for } \\
\text { analytical gases is stated under the emissions test equipment provisions for control of } \\
\text { emissions from new and in-use nonroad compression-ignition engines. }\end{array}$ & EPA & 40 CFR 89.312(c)(1) \\
\hline Traceability/calibration & $\begin{array}{l}\text { Requires that "The true concentration of a span gas must be within } \pm 2 \text { percent of the } \\
\text { NIST gas standard. The true concentration of a calibration gas must be within } \pm 1 \\
\text { percent of the NIST gas standard. The use of precision blending devices (gas dividers) } \\
\text { to obtain the required calibration gas concentrations is acceptable, provided that the } \\
\text { blended gases are accurate to within } \pm 1.5 \text { percent of NIST gas standards, or other gas } \\
\text { standards which have been approved by the Administrator. This accuracy implies that } \\
\text { primary gases used (or blending) must be "named" to an accuracy of at least } \pm 1 \\
\text { percent, traceable to NIST or other approved gas standards. All concentrations of } \\
\text { calibration gas shall be given on a volume basis (volume percent or volume ppm)." } \\
\text { This requirement for analytical gases is stated under the emissions test equipment } \\
\text { provisions for control of emissions from new and in-use nonroad compression-ignition } \\
\text { engines. }\end{array}$ & EPA & 40 CFR 89.312(c)(1) \\
\hline Traceability/calibration & $\begin{array}{l}\text { States that "the CVS is calibrated using an accurate flowmeter and restrictor valve } \\
\text { where the flowmeter calibration must be traceable to NIST measurements, and will } \\
\text { serve as the reference value (NIST "true" value) for the CVS calibration". This } \\
\text { requirement is for CVS calibrations for dilute sampling procedures stated for test } \\
\text { procedures for exhaust emissions in testing for control of emissions from new and in- } \\
\text { use nonroad compression-ignition engines. }\end{array}$ & EPA & 40 CFR 89.422(a)(1) \\
\hline
\end{tabular}

Appendix 5 


\begin{tabular}{|c|c|c|c|}
\hline Traceability & $\begin{array}{l}\text { States that "The CVS calibration procedures are designed for use of a "metering } \\
\text { venturi" type flowmeter. Large radius or ASME flow nozzles are considered } \\
\text { equivalent if traceable to NIST measurements. Other measurement systems may be } \\
\text { used if shown to be equivalent under the test conditions in this section and traceable to } \\
\text { NIST measurements." This requirement is for CVS calibrations for dilute sampling } \\
\text { procedures stated for test procedures for exhaust emissions in testing for control of } \\
\text { emissions from new and in-use nonroad compression-ignition engines. }\end{array}$ & EPA & 40 CFR 89.422(a)(2) \\
\hline Traceability & $\begin{array}{l}\text { Requires that air flow sensor read out tolerances for calibration data measurements } \\
\text { must be } \pm 0.5 \% \text { of NBS "true" value. (MANDATORY if this technique is used). This } \\
\text { measurement is part of the PDP calibration is one of the required measurements that } \\
\text { establishes flow rate of the CVS pump. This requirement is for CVS calibrations for } \\
\text { dilute sampling procedures used for test procedures for exhaust emissions in testing } \\
\text { for control of emissions from new and in-use nonroad compression-ignition engines. }\end{array}$ & EPA & 40 CFR 89.422(c)(4) \\
\hline Traceability/calibration & $\begin{array}{l}\text { The regulation states that to ensure dynamometer calibration accuracy a minimum of } \\
\text { three calibration weights for each range used is required. The weights must be equally } \\
\text { spaced and traceable to within } 0.5 \text { percent of National Institute for Standards and } \\
\text { Testing (NIST) weights. Laboratories located in foreign countries may certify } \\
\text { calibration weights to local government bureau standards". This regulation is included } \\
\text { in the emission test equipment provisions for control of emissions from nonroad } \\
\text { spark-ignition engines at or below } 19 \mathrm{~kW} \text {. }\end{array}$ & EPA & 40 CFR 90.305(b)(2) \\
\hline $\begin{array}{l}\text { Traceability/calibration/ } \\
\text { SRMs }\end{array}$ & $\begin{array}{l}\text { Specifies accuracy requirements for divider gases, if used, as part of emission test } \\
\text { equipment provisions for control of emissions from nonroad spark-ignition engines at } \\
\text { or below } 19 \mathrm{~kW} \text {. The regulations states that "the use of precision blending devices (gas } \\
\text { dividers) to obtain the required calibration gas concentrations is acceptable, provided } \\
\text { that the blended gases are accurate to within } \pm 1.5 \text { percent of NIST gas standards or } \\
\text { other gas standards which have been approved by the Administrator. This accuracy } \\
\text { implies that primary gases used for blending must be "named" to an accuracy of at } \\
\text { least } \pm \text { one percent, traceable to NIST or other approved gas standards". }\end{array}$ & EPA & 40 CFR 90.314(c)(Note) \\
\hline Traceability/SRMs & $\begin{array}{l}\text { Specifies requirements for span gases, if used, as part of emission test equipment } \\
\text { provisions for control of emissions from nonroad spark-ignition engines at or below } \\
19 \mathrm{~kW} \text {. States that "The span gases must be accurate to within } \pm \text { two percent of NIST } \\
\text { gas standards or other gas standards which have been approved by the Administrator.". }\end{array}$ & EPA & 40 CFR 90.314(c)(i) \\
\hline Traceability/calibration & $\begin{array}{l}\text { States that for diluting sampling procedures used in gaseous exhaust test procedures } \\
\text { for control of emissions from nonroad spark-ignition engines at or below } 19 \mathrm{~kW} \text {, the } \\
\text { CVS has to be calibrated using an accurate flowmeter and restrictor valve. The } \\
\text { "flowmeter calibration must be traceable to the National Institute for Standards and } \\
\text { Testing (NIST) and serves as the reference value (NIST "true" value) for the CVS } \\
\text { calibration" (MANDATORY). }\end{array}$ & EPA & 40 CFR 90.424(a)(1) \\
\hline
\end{tabular}

Appendix 5 


\begin{tabular}{|c|c|c|c|}
\hline Traceability/calibration & $\begin{array}{l}\text { States that for diluting sampling procedures used in gaseous exhaust test procedures } \\
\text { for control of emissions from nonroad spark-ignition engines at or below } 19 \mathrm{~kW} \text {, the } \\
\text { CVS has to be calibrated using an accurate flowmeter and restrictor valve. The } \\
\text { regulation states that "large radius or American Society of Mechanical Engineers } \\
\text { (ASME) flow nozzles are considered equivalent if traceable to NIST measurements. } \\
\text { Other measurement systems may be used if shown to be equivalent under the test } \\
\text { conditions in the section and traceable to NIST measurements". }\end{array}$ & EPA & 40 CFR 90.424(a)(2) \\
\hline Traceability/calibration & $\begin{array}{l}\text { Regulation requires that sensor-readout tolerances for airflow during calibration data } \\
\text { measurements must be } \pm 0.5 \text { percent of NIST value (MANDATORY). This } \\
\text { measurement is part of the test configuration required to establish the flow rate of the } \\
\text { CVS pump for PDP-CVS calibration for diluting sampling procedures used in gaseous } \\
\text { exhaust test procedures for control of emissions from nonroad spark-ignition engines } \\
\text { at or below } 19 \mathrm{~kW} \text {. }\end{array}$ & EPA & 40 CFR 90.424(c)(4) \\
\hline Traceability/calibration & $\begin{array}{l}\text { Regulation requires that sensor-readout tolerances for airflow during calibration data } \\
\text { measurements must be } \pm 0.5 \text { percent of NIST value (MANDATORY). This } \\
\text { measurement is part of the test configuration required for flow calibration as part of } \\
\text { the CFV-CVS calibration for diluting sampling procedures used in gaseous exhaust } \\
\text { test procedures for control of emissions from nonroad spark-ignition engines at or } \\
\text { below } 19 \mathrm{~kW} \text {. }\end{array}$ & EPA & 40 CFR 90.424(c)(4) \\
\hline Traceability & $\begin{array}{l}\text { The dynamometers specifications and calibration accuracy requirements stated as part } \\
\text { of the emissions test provisions for control of emissions from marine spark- ignition } \\
\text { engines require that "a minimum of three calibration weights for each range used is } \\
\text { required. The weights must be equally spaced and traceable to within } 0.5 \text { percent of } \\
\text { National Institute of Standards and Testing (NIST) weights. Laboratories located in } \\
\text { foreign countries may certify calibration weights to local government bureau } \\
\text { standards". }\end{array}$ & EPA & 40 CFR 91.305(b)(2) \\
\hline Traceability to SRM & $\begin{array}{l}\text { This reference pertains to calibration of emission measurement equipment using bag } \\
\text { sampling techniques, when emissions are below } 15 \% \text { of the full scale reading. The } \\
\text { regulation states emissions test equipment provisions for control of emissions from } \\
\text { marine spark-ignition engines. The reference states that "the use of precision blending } \\
\text { devices (gas dividers) to obtain the required calibration gas concentrations is } \\
\text { acceptable, provided that the blended gases are accurate to within } \pm 1.5 \text { percent of } \\
\text { NIST gas standards or other gas standards which have been approved by the } \\
\text { Administrator. This accuracy implies that primary gases used for blending must be } \\
\text { "named" to an accuracy of at least } \pm 1 \text { percent, traceable to NIST or other approved } \\
\text { gas standards". }\end{array}$ & EPA & 40 CFR 91.314(c)(2) \\
\hline Traceability to SRM & $\begin{array}{l}\text { This regulation states that when span gases are used in analyzers for emissions testing } \\
\text { for control of emissions from marine spark-ignition engines the procedure used should } \\
\text { "span the full analyzer range using a top range calibration gas. The span gases must be } \\
\text { accurate to within } \pm 2 \text { percent of NIST gas standards or other gas standards which } \\
\text { have been approved by the Administrator". }\end{array}$ & EPA & 40 CFR 91.314(c)(2)(i) \\
\hline
\end{tabular}

Appendix 5 


\begin{tabular}{|c|c|c|c|}
\hline Traceability to SRM & $\begin{array}{l}\text { As per this regulation, when calibrating an analyzer for emissions testing for control of } \\
\text { emissions from marine spark-ignition engines, "select a calibration gas (a span gas } \\
\text { may be used for calibrating the } \mathrm{CO} 2 \text { analyzer) with a concentration between the two } \\
\text { lowest non-zero gas divider increments. This gas must be "named" to an accuracy of } \pm \\
2 \text { percent of NIST gas standards, or other standards approved by the Administrator". }\end{array}$ & EPA & 40 CFR $91.314(\mathrm{c})(2)(\mathrm{iii})$ \\
\hline Traceability & $\begin{array}{l}\text { States that for diluting sampling procedures used in gaseous exhaust test procedures } \\
\text { for control of emissions from marine spark-ignition engines, the CVS has to be } \\
\text { calibrated using an accurate flowmeter and restrictor valve. The "flowmeter } \\
\text { calibration shall be traceable to the National Institute for Standards and Testing } \\
\text { (NIST) and will serve as the reference value (NIST "true" value) for the CVS } \\
\text { calibration" (MANDATORY). }\end{array}$ & EPA & 40 CFR 91.424(a)(1) \\
\hline Traceability & $\begin{array}{l}\text { States that for diluting sampling procedures used in gaseous exhaust test procedures } \\
\text { for control of emissions from marine spark-ignition engines, the CVS has to be } \\
\text { calibrated using an accurate flowmeter and restrictor valve. The regulation states that } \\
\text { "large radius or American Society of Mechanical Engineers (ASME) flow nozzles are } \\
\text { considered equivalent if traceable to NIST measurements. Other measurement systems } \\
\text { may be used if shown to be equivalent under the test conditions in the section and } \\
\text { traceable to NIST measurements". }\end{array}$ & EPA & 40 CFR 91.424(a)(2) \\
\hline Traceability & $\begin{array}{l}\text { Regulation requires that sensor-readout tolerances for airflow during calibration data } \\
\text { measurements must be } \pm 0.5 \text { percent of NIST value (MANDATORY). This } \\
\text { measurement is part of the test configuration required to establish the flow rate of the } \\
\text { CVS pump for PDP-CVS calibration for diluting sampling procedures used in gaseous } \\
\text { exhaust test procedures for control of emissions from marine spark-ignition engines. }\end{array}$ & EPA & 40 CFR 91.424(c)(4) \\
\hline Traceability & $\begin{array}{l}\text { Regulation requires that sensor-readout tolerances for airflow during calibration data } \\
\text { measurements must be } \pm 0.5 \text { percent of NIST value (MANDATORY). This } \\
\text { measurement is part of the test configuration required for flow calibration as part of } \\
\text { the CFV-CVS calibration for diluting sampling procedures used in gaseous exhaust } \\
\text { test procedures for control of emissions from marine spark-ignition engines. }\end{array}$ & EPA & 40 CFR 91.424(d)(3) \\
\hline Traceability & $\begin{array}{l}\text { Defines accuracy as "the difference between the measured value and the true value, } \\
\text { where the true value is determined from NIST traceable measurements where possible, } \\
\text { or otherwise determined by good engineering practice" }\end{array}$ & EPA & 40 CFR 92.102 \\
\hline Traceability & $\begin{array}{l}\text { This regulation requires that in addition to certain general requirements, for purposes } \\
\text { of engine testing, the engine or dynamometer readout signals for speed and torque } \\
\text { shall also meet the following accuracy specifications, amongst others:" Engine } \\
\text { flywheel torque readout shall be accurate to either within } \pm 3 \text { percent of the NIST } \\
\text { "true" value torque, or the following accuracies, whichever provides the most accurate } \\
\text { readout:(A) } \pm 20 \mathrm{ft} \text {-lbs. of the NIST "true" value if the full scale value is } 9000 \mathrm{ft} .-1 b s . \\
\text { or less. (B) } \pm 30 \mathrm{ft} \text {.-lbs., of the NIST "true" value if the full scale value is greater than } \\
9000 \mathrm{ft} \text {.-lbs". This specification for engine testing is defined as a test procedure for } \\
\text { control of air pollution from locomotives and locomotive engines. }\end{array}$ & EPA & 40 CFR 92.106(b)(1)(ii) \\
\hline
\end{tabular}

Appendix 5 


\begin{tabular}{|c|c|c|c|}
\hline Traceability/SRM & $\begin{array}{l}\text { As per this regulation, calibration gases used as analytical gases in test procedures for } \\
\text { control of air pollution from locomotives and locomotive engines, "shall be accurate to } \\
\text { within } \pm 1 \text { percent of NIST gas standards, or other gas standards which have been } \\
\text { approved by the Administrator". }\end{array}$ & EPA & 40 CFR 92.112(h)(2) \\
\hline Traceability/SRM & $\begin{array}{l}\text { As per this regulation, span gases used as analytical gases in test procedures for } \\
\text { control of air pollution from locomotives and locomotive engines, "shall be accurate to } \\
\text { within } \pm 2 \text { percent of NIST gas standards, or other gas standards which have been } \\
\text { approved by the Administrator.". }\end{array}$ & EPA & 40 CFR 92.112(h)(3) \\
\hline Traceability/SRM & $\begin{array}{l}\text { As per this regulation, for analytical gases in test procedures for control of air } \\
\text { pollution from locomotives and locomotive engines, "the use of precision blending } \\
\text { devices (gas dividers) to obtain the required calibration gas concentrations is } \\
\text { acceptable, provided that the blended gases are accurate to within } \pm 1.5 \text { percent of } \\
\text { NIST gas standards, or other gas standards which have been approved by the } \\
\text { Administrator. This accuracy implies that primary gases used for blending must be } \\
\text { "named" to an accuracy of at least } \pm 1 \text { percent, traceable to NIST or other approved gas } \\
\text { standards.". }\end{array}$ & EPA & 40 CFR 92.112(j) \\
\hline Traceability & $\begin{array}{l}\text { This reference defines NIST "true" value torque for dynamometer equipment } \\
\text { calibration as part of the calibration of engine output measurement system for test } \\
\text { procedures used in control of air pollution from locomotives and locomotive engines. } \\
\text { The NIST "true" value torque is defined as "the torque calculated by taking the } \\
\text { product of an NIST traceable weight or force and a sufficiently accurate horizontal } \\
\text { lever arm distance, corrected for the hanging torque of the lever arm". }\end{array}$ & EPA & 40 CFR 92.116(b)(1) \\
\hline Traceability & $\begin{array}{l}\text { Regulation specifies the requirement of calibration weights as "a minimum of six } \\
\text { calibration weights for each range of torque measuring device used are required. The } \\
\text { weights must be approximately equally spaced and each must be traceable to NIST } \\
\text { weights within } 0.1 \text { percent. Laboratories located in foreign countries may certify } \\
\text { calibration weights to local government bureau standards. Certification of weight by } \\
\text { state government Bureau of Weights and Measures is acceptable. Effects of changes in } \\
\text { gravitational constant at the test site may be accounted for if desired." This is used for } \\
\text { dynamometer equipment calibration as part of the calibration of engine output } \\
\text { measurement system for test procedures used in control of air pollution from } \\
\text { locomotives and locomotive engines. }\end{array}$ & EPA & $\begin{array}{l}40 \text { CFR } \\
92.116(\mathrm{~b})(1)(\mathrm{i})(\mathrm{A})\end{array}$ \\
\hline Traceability & $\begin{array}{l}\text { States calibration requirements for a master load cell shall be precalibrated or } \\
\text { calibrated with known weights traceable to NIST within } 0.1 \text { percent ... This } \\
\text { requirement is for equipment calibration as part of the calibration of engine output } \\
\text { measurement system for test procedures used in control of air pollution from } \\
\text { locomotives and locomotive engines. }\end{array}$ & EPA & $\begin{array}{l}40 \text { CFR } \\
92.116(\mathrm{~b})(1)(\mathrm{ii})(\mathrm{A})\end{array}$ \\
\hline
\end{tabular}




\begin{tabular}{|c|c|c|c|}
\hline Traceability & $\begin{array}{l}\text { This regulation requires that the calibration weights used to calibrate the master load } \\
\text { cell and read out system for dynamometer equipment calibration as part of the } \\
\text { calibration of engine output measurement system for test procedures used in control of } \\
\text { air pollution from locomotives and locomotive engines must be traceable to within } 0.1 \\
\text { percent of NIST weights. (MANDATORY) }\end{array}$ & EPA & 40 CFR 92.116(c)(3)(i) \\
\hline Traceability/calibration & $\begin{array}{l}\text { This regulation requires that for calibration of gas meters or flow instruments used for } \\
\text { particle measurement in test procedures used to control air pollution from locomotive } \\
\text { and locomotive engines, the calibration device should be installed in series with the } \\
\text { instrument. "A critical flow orifice, a bellmouth nozzle, or a laminar flow element or } \\
\text { an NIST traceable flow calibration device is required as the standard device." } \\
\text { (MANDATORY) }\end{array}$ & EPA & 40 CFR 92.117(a)(1)(i) \\
\hline Traceability to SRM & $\begin{array}{l}\text { This regulation defines procedures for smoke meter testing and calibration used in test } \\
\text { procedures for control of air pollution from locomotives and locomotive engines. The } \\
\text { regulation specifies that "Calibrated neutral density filters having approximately } 10, \\
20 \text {, and } 40 \text { percent opacity shall be employed to check the linearity of the instrument. } \\
\text { The filter(s) shall be inserted in the light path perpendicular to the axis of the beam } \\
\text { and adjacent to the opening from which the beam of light from the light source } \\
\text { emanates, and the recorder response shall be noted. Filters with exposed filtering } \\
\text { media should be checked for opacity every six months; all other filters shall be } \\
\text { checked every year, using NIST or equivalent reference filters". }\end{array}$ & EPA & 40 CFR 92.122(b) \\
\hline Traceability to SRM & $\begin{array}{l}\text { This regulation states that for calibrating exhaust emissions sample analyzers that will } \\
\text { be used for readings below } 15 \% \text { full scale deflection, in order to ensure accuracy of } \\
\text { the calibration curves the calibration procedure should involve amongst other steps } \\
\text { selection of a" calibration gas (a span gas may be used for calibrating the CO2 } \\
\text { analyzer) with a concentration between the two lowest non-zero gas divider } \\
\text { increments. This gas must be "named" to an accuracy of } \pm 1.0 \text { percent }( \pm 2.0 \text { percent for } \\
\mathrm{CO} 2 \text { span gas) of NIST gas standards, or other standards approved by the } \\
\text { Administrator." This is part of the procedure to ensure emissions measurement } \\
\text { accuracy in test procedures used to control air pollution from locomotives and } \\
\text { locomotive engines. }\end{array}$ & EPA & 40 CFR 92.127(b)(1)(iii) \\
\hline Traceability to SRM & $\begin{array}{l}\text { This regulation defines the test procedures for category } 3 \text { marine engines as part of the } \\
\text { test procedures for control of emissions from marine compression-ignition engines. } \\
\text { The regulation states that "standards used for calibration shall be traceable to NIST } \\
\text { standards. (Other national standards may be used if they have been shown to be } \\
\text { equivalent to NIST standards.)".(MANDATORY) }\end{array}$ & EPA & 40 CFR 94.109(a)(5) \\
\hline Traceability & $\begin{array}{l}\text { This regulation defines a stock solution as "a solution containing an analyte that is } \\
\text { prepared using a reference material traceable to EPA, the National Institute of Science } \\
\text { and Technology (NIST), or a source that will attest to the purity and authenticity of the } \\
\text { reference material" in the glossary of definitions and purposes under the guidelines } \\
\text { establishing test procedures for analysis of pollutants, with particular reference to } \\
\text { "Methods for Organic Chemical Analysis of Municipal and Industrial Wastewater". }\end{array}$ & EPA & 40 CFR 136 App. A (25) \\
\hline
\end{tabular}

Appendix 5 


\begin{tabular}{|c|c|c|c|}
\hline NBS testing labs & $\begin{array}{l}\text { This section of the subchapter requires that all tests pertaining to deck coverings have } \\
\text { to be conducted at the NBS or other laboratories designated by the Coast Guard for } \\
\text { purposes of inspection and testing of deck coverings for merchant vessels. }\end{array}$ & DHS/USCG & 46 CFR 164.006-4(a) \\
\hline NBS testing labs & $\begin{array}{l}\text { Reference is made to the NBS labs as the site of testing materials to be approved for } \\
\text { use as deck covering in merchant vessels. }\end{array}$ & DHS/USCG & 46 CFR $164.006-5(d)$ \\
\hline NBS testing labs & $\begin{array}{l}\text { This reference states that all tests and retests pertaining to structural insulations have } \\
\text { to be conducted at the NBS or other laboratories designated by the Coast Guard. }\end{array}$ & DHS/USCG & 46 CFR 164.007-4(a) \\
\hline NBS testing labs & $\begin{array}{l}\text { Reference is made to the Fire Research Section of NBS as the site of testing materials } \\
\text { to be approved for use as structural insulations. }\end{array}$ & DHS/USCG & 46 CFR 164.007-9(c) \\
\hline NBS testing labs & $\begin{array}{l}\text { Reference is made to the NBS or other labs designated by the Coast Guard as the site } \\
\text { for all tests and retests for bulkhead panels. }\end{array}$ & DHS/USCG & 46 CFR 164.008-3(a) \\
\hline NBS testing labs & $\begin{array}{l}\text { Procedures for testing of materials as bulkhead panels at the Fire Research Section of } \\
\text { NBS, and related administrative procedures are defined. }\end{array}$ & DHS/USCG & $\begin{array}{l}\text { 46 CFR 164.008- } \\
7(\mathrm{c}) \text { and(d) }\end{array}$ \\
\hline NBS time standards & $\begin{array}{l}\text { The FCC stipulates that "The primary standard of frequency for radio frequency } \\
\text { measurements is the standard frequency maintained by the National Bureau of } \\
\text { Standards or the standard signals of Stations WWV, WWVB, and WWVH of the } \\
\text { National Bureau of Standards". }\end{array}$ & FCC & 47 CFR 73.1540 \\
\hline Calibration & $\begin{array}{l}\text { The NBS is stated as the source of calibration services for DoE acquisition officers or } \\
\text { its authorized contractors. }\end{array}$ & DOE & 48 CFR 908.7113 \\
\hline
\end{tabular}

\section{Appendix 5}




\section{SRM References to NIST and NBS in the Code of Federal Regulations}

\begin{tabular}{|c|c|c|c|c|}
\hline $\begin{array}{l}\text { Document } \\
\text { Number }\end{array}$ & Title of Document & $\begin{array}{l}\text { Edition } \\
\text { Date }\end{array}$ & $\begin{array}{l}\text { Incorporated } \\
\text { By }\end{array}$ & $\begin{array}{l}\text { Location in } \\
\text { CFR }\end{array}$ \\
\hline $\begin{array}{l}\text { NBS } \\
\text { Material } \\
\text { No. } 577\end{array}$ & $\begin{array}{l}\text { Specifies spectrophotometric measurements as "All measurements are } \\
\text { made in an ultraviolet spectrophotometer in optical cells of } 5 \\
\text { centimeters in length, and in the range of } 255 \text { millimicrons to } 310 \\
\text { millimicrons, under the same instrumental conditions. The standard } \\
\text { reference absorbance is the absorbance at } 275 \text { millimicrons of a } \\
\text { standard reference solution of naphthalene (National Bureau of } \\
\text { Standards Material No. } 577 \text { or equivalent in purity) containing a } \\
\text { concentration of } 1.4 \text { milligrams per liter in purified isooctane, } \\
\text { measured against isooctane of the same spectral purity in 5-centimeter } \\
\text { cells. (This absorbance will be approximately } 0.30 \text {.)" as a test for } \\
\text { compliance that food additive combustion product gas may be safely } \\
\text { used in the processing and packaging of the foods for the purpose of } \\
\text { removing and displacing oxygen. }\end{array}$ & & HHS/FDA & $\begin{array}{c}21 \mathrm{CFR} \\
173.350(\mathrm{e})\end{array}$ \\
\hline SRM 2670 & $\begin{array}{l}\text { Refers to SRM } 2670 \text { as a source of reference materials that maybe } \\
\text { available for use in QC/QA analyses of Cadmium in Urine under the } \\
\text { Occupational Safety and Health Standards for Hazardous and Toxic } \\
\text { Materials. The reference reads "National Institute of Standards and } \\
\text { Technology (NIST), Dept. of Commerce, Gaithersburg, MD; tel: (301) } \\
\text { 975-6776. (Prepared as SRM } 2670 \text { freeze-dried urine [metals]; set } \\
\text { includes normal and elevated levels of metals; cadmium is certified for } \\
\text { elevated level of } 88.0 \mu \mathrm{g} / \mathrm{l} \text { in reconstituted urine.)". }\end{array}$ & & DOL/OSHA & $\begin{array}{l}29 \mathrm{CFR} \\
1910.1027 \\
3.3 .1 .1\end{array}$ \\
\hline SRM 1582 & $\begin{array}{l}\text { NIST SRM } 1582 \text { petroleum crude oil is stated as the Standard crude } \\
\text { oil for Reverse Phase Extraction (RPE) Method for Detection of Oil } \\
\text { Contamination in Non-Aqueous Drilling Fluids (NAF), under the } \\
\text { regulations in the oil and gas extraction point source category. }\end{array}$ & & EPA & $\begin{array}{l}40 \text { CFR } 435 \\
\text { Appendix } 6 ; 7.3\end{array}$ \\
\hline SRM & $\begin{array}{l}\text { Definitions -defines "traceable" as a local standard has been compared } \\
\text { and certified either directly or via not more than one intermediate } \\
\text { standard, to a primary standard such as a National Bureau of Standards } \\
\text { Standard Reference Material (NBS SRM), or a USEPA/NBS-approved } \\
\text { Certified Reference Material (CRM) - and hence references NBS } \\
\text { SRMs. }\end{array}$ & & EPA & 40 CFR 50.1 \\
\hline
\end{tabular}




\begin{tabular}{|c|c|c|c|}
\hline $\begin{array}{l}\text { NBS SRM } \\
1625\end{array}$ & $\begin{array}{l}\text { In the dynamic calibration procedures used as part of the Reference } \\
\text { Method for the Determination of Sulfur Dioxide in the Atmosphere } \\
\text { (Pararosaniline Method), under the National Primary and Secondary } \\
\text { Ambient Air Quality Standards, "Atmospheres containing accurately } \\
\text { known concentrations of sulfur dioxide are prepared using permeation } \\
\text { devices. In the systems for generating these atmospheres, the } \\
\text { permeation device emits gaseous SO } 2 \text { at a known, low, constant rate, } \\
\left.\text { provided the temperature of the device is held constant ( } \pm 0.1^{\circ} \mathrm{C}\right) \text { and } \\
\text { the device has been accurately calibrated at the temperature of use. } \\
\text { The SO2 permeating from the device is carried by a low flow of dry } \\
\text { carrier gas to a mixing chamber where it is diluted with SO2-free air to } \\
\text { the desired concentration and supplied to a vented manifold." Further, } \\
\text { "Permeation devices" as described above "may be prepared or } \\
\text { purchased and in both cases must be traceable either to a National } \\
\text { Bureau of Standards (NBS) Standard Reference Material (SRM } 1625 \text {, } \\
\text { SRM } 1626 \text {, SRM 1627) or to an NBS/EPA-approved commercially } \\
\text { available Certified Reference Material (CRM)." }\end{array}$ & EPA & $\begin{array}{l}40 \text { CFR } 50 \\
\text { Appendix A } \\
10.3\end{array}$ \\
\hline $\begin{array}{l}\text { NBS SRM } \\
1626\end{array}$ & $\begin{array}{l}\text { In the dynamic calibration procedures used as part of the Reference } \\
\text { Method for the Determination of Sulfur Dioxide in the Atmosphere } \\
\text { (Pararosaniline Method), under the National Primary and Secondary } \\
\text { Ambient Air Quality Standards, "Atmospheres containing accurately } \\
\text { known concentrations of sulfur dioxide are prepared using permeation } \\
\text { devices. In the systems for generating these atmospheres, the } \\
\text { permeation device emits gaseous SO } 2 \text { at a known, low, constant rate, } \\
\text { provided the temperature of the device is held constant }\left( \pm 0.1^{\circ} \mathrm{C}\right) \text { and } \\
\text { the device has been accurately calibrated at the temperature of use. } \\
\text { The SO2 permeating from the device is carried by a low flow of dry } \\
\text { carrier gas to a mixing chamber where it is diluted with SO2-free air to } \\
\text { the desired concentration and supplied to a vented manifold." Further, } \\
\text { "Permeation devices" as described above "may be prepared or } \\
\text { purchased and in both cases must be traceable either to a National } \\
\text { Bureau of Standards (NBS) Standard Reference Material (SRM } 1625 \text {, } \\
\text { SRM 1626, SRM 1627) or to an NBS/EPA-approved commercially } \\
\text { available Certified Reference Material (CRM)." }\end{array}$ & EPA & $\begin{array}{l}40 \text { CFR } 50 \\
\text { Appendix A } 10.3\end{array}$ \\
\hline
\end{tabular}




\begin{tabular}{|c|c|c|c|}
\hline $\begin{array}{l}\text { NBS SRM } \\
1627\end{array}$ & $\begin{array}{l}\text { In the dynamic calibration procedures used as part of the Reference } \\
\text { Method for the Determination of Sulfur Dioxide in the Atmosphere } \\
\text { (Pararosaniline Method), under the National Primary and Secondary } \\
\text { Ambient Air Quality Standards, "Atmospheres containing accurately } \\
\text { known concentrations of sulfur dioxide are prepared using permeation } \\
\text { devices. In the systems for generating these atmospheres, the } \\
\text { permeation device emits gaseous SO2 at a known, low, constant rate, } \\
\left.\text { provided the temperature of the device is held constant ( } \pm 0.1^{\circ} \mathrm{C}\right) \text { and } \\
\text { the device has been accurately calibrated at the temperature of use. } \\
\text { The SO2 permeating from the device is carried by a low flow of dry } \\
\text { carrier gas to a mixing chamber where it is diluted with SO2-free air to } \\
\text { the desired concentration and supplied to a vented manifold." Further, } \\
\text { "Permeation devices" as described above "may be prepared or } \\
\text { purchased and in both cases must be traceable either to a National } \\
\text { Bureau of Standards (NBS) Standard Reference Material (SRM } 1625 \text {, } \\
\text { SRM } 1626, \text { SRM 1627) or to an NBS/EPA-approved commercially } \\
\text { available Certified Reference Material (CRM)." }\end{array}$ & EPA & $\begin{array}{l}40 \text { CFR } 50 \\
\text { Appendix A } 10.3\end{array}$ \\
\hline $\begin{array}{l}\text { NBS SRM } \\
1629\end{array}$ & $\begin{array}{l}\text { In stating the Measurement Principle and Calibration Procedure for the } \\
\text { Measurement of Nitrogen Dioxide in the Atmosphere (Gas Phase } \\
\text { Chemiluminescence), under the National Primary and Secondary } \\
\text { Ambient Air Quality Standards, for calibration using gas phase } \\
\text { titration of an NO standard with ozone, the NO concentration standard } \\
\text { should be a "Gas cylinder standard containing } 50 \text { to } 100 \text { ppm NO in } \\
\text { N2 with less than } 1 \text { ppm NO2". Further, "This standard must be } \\
\text { traceable to a National Bureau of Standards (NBS) NO in N2 Standard } \\
\text { Reference Material (SRM } 1683 \text { or SRM 1684), an NBS NO2 Standard } \\
\text { Reference Material (SRM 1629), or an NBS/EPA-approved } \\
\text { commercially available Certified Reference Material (CRM) ". } \\
\text { Similarly, for calibration using NO2 permeation devices "Calibration } \\
\text { standards are required for both NO and NO2. The reference standard } \\
\text { for the calibration may be either an NO or NO2 standard, and must be } \\
\text { traceable to a National Bureau of Standards (NBS) NO in N2 Standard } \\
\text { Reference Material (SRM } 1683 \text { or SRM 1684), and NBS NO2 } \\
\text { Standard Reference Material (SRM 1629), or an NBS/EPA-approved } \\
\text { commercially available Certified Reference Material (CRM)". }\end{array}$ & EPA & $\begin{array}{c}40 \text { CFR } 50 \\
\text { Appendix F } \\
1.3 .1,2.3 .1\end{array}$ \\
\hline
\end{tabular}




\begin{tabular}{|c|c|c|c|}
\hline $\begin{array}{l}\text { NBS SRM } \\
1683\end{array}$ & $\begin{array}{l}\text { In stating the Measurement Principle and Calibration Procedure for the } \\
\text { Measurement of Nitrogen Dioxide in the Atmosphere (Gas Phase } \\
\text { Chemiluminescence), under the National Primary and Secondary } \\
\text { Ambient Air Quality Standards, for calibration using gas phase } \\
\text { titration of an NO standard with ozone, the NO concentration standard } \\
\text { should be a "Gas cylinder standard containing } 50 \text { to } 100 \text { ppm NO in } \\
\text { N2 with less than } 1 \text { ppm NO2". Further, "This standard must be } \\
\text { traceable to a National Bureau of Standards (NBS) NO in N2 Standard } \\
\text { Reference Material (SRM } 1683 \text { or SRM 1684), an NBS NO2 Standard } \\
\text { Reference Material (SRM 1629), or an NBS/EPA-approved } \\
\text { commercially available Certified Reference Material (CRM) ". } \\
\text { Similarly, for calibration using NO2 permeation devices "Calibration } \\
\text { standards are required for both NO and NO2. The reference standard } \\
\text { for the calibration may be either an NO or NO2 standard, and must be } \\
\text { traceable to a National Bureau of Standards (NBS) NO in N2 Standard } \\
\text { Reference Material (SRM } 1683 \text { or SRM 1684), and NBS NO2 } \\
\text { Standard Reference Material (SRM 1629), or an NBS/EPA-approved } \\
\text { commercially available Certified Reference Material (CRM)". }\end{array}$ & EPA & $\begin{array}{c}40 \text { CFR } 50 \\
\text { Appendix F } \\
1.3 .1,2.3 .1\end{array}$ \\
\hline $\begin{array}{l}\text { NBS SRM } \\
1684\end{array}$ & $\begin{array}{l}\text { In stating the Measurement Principle and Calibration Procedure for the } \\
\text { Measurement of Nitrogen Dioxide in the Atmosphere (Gas Phase } \\
\text { Chemiluminescence), under the National Primary and Secondary } \\
\text { Ambient Air Quality Standards, for calibration using gas phase } \\
\text { titration of an NO standard with ozone, the NO concentration standard } \\
\text { should be a "Gas cylinder standard containing } 50 \text { to } 100 \text { ppm NO in } \\
\text { N2 with less than } 1 \text { ppm NO2". Further, "This standard must be } \\
\text { traceable to a National Bureau of Standards (NBS) NO in N2 Standard } \\
\text { Reference Material (SRM 1683 or SRM 1684), an NBS NO2 Standard } \\
\text { Reference Material (SRM 1629), or an NBS/EPA-approved } \\
\text { commercially available Certified Reference Material (CRM) ". } \\
\text { Similarly, for calibration using NO2 permeation devices "Calibration } \\
\text { standards are required for both NO and NO2. The reference standard } \\
\text { for the calibration may be either an NO or NO2 standard, and must be } \\
\text { traceable to a National Bureau of Standards (NBS) NO in N2 Standard } \\
\text { Reference Material (SRM } 1683 \text { or SRM 1684), and NBS NO2 } \\
\text { Standard Reference Material (SRM 1629), or an NBS/EPA-approved } \\
\text { commercially available Certified Reference Material (CRM)". }\end{array}$ & EPA & $\begin{array}{c}40 \text { CFR } 50 \\
\text { Appendix F } \\
1.3 .1,2.3 .1\end{array}$ \\
\hline
\end{tabular}




\begin{tabular}{|c|c|c|c|}
\hline $\begin{array}{l}\text { NBS } \\
\text { standards }\end{array}$ & $\begin{array}{l}\text { Requires the use of "NBS-certified standards whenever possible", for } \\
\text { verifying the concentrations of generated test atmospheres, (in } \\
\text { particular Carbon dioxide, methane, xylene) as part of the Procedures } \\
\text { for Testing Performance Characteristics of Automated Methods SO2, } \\
\mathrm{CO}, \mathrm{O} 3 \text {, and NO2, under testing for ambient air monitoring reference } \\
\text { and equivalent methods. The regulations further state that "if NBS } \\
\text { standards are not available, obtain } 2 \text { standards from independent } \\
\text { sources which agree to within } 2 \text { percent; or obtain one standard and } \\
\text { submit it to an independent laboratory for analysis which must agree } \\
\text { within } 2 \text { percent of the supplier's nominal analysis". } \\
\text { Carbon dioxide, methane, xylene }\end{array}$ & EPA & 40 CFR 53.22 \\
\hline SRM & $\begin{array}{l}\text { States that "working and transfer standards and equipment used for } \\
\text { auditing must be different from the standards and equipment used for } \\
\text { calibration and spanning. The auditing standards and calibration } \\
\text { standards may be referenced to the same NIST, SRM, CRM, or } \\
\text { primary UV photometer" as part of the procedure to determine } \\
\text { accuracy of automated methods under the data quality assessment } \\
\text { requirements for Prevention of Significant Deterioration (PSD) Air } \\
\text { Monitoring for Ambient Air Quality Surveillance. }\end{array}$ & EPA & $\begin{array}{l}40 \text { CFR 58; } \\
\text { Appendix B } 3.2\end{array}$ \\
\hline SRM & $\begin{array}{l}\text { Requires "the use of cylinder gases that have been certified by } \\
\text { comparison to National Institute of Standards and Technology (NIST) } \\
\text { gaseous standard reference material (SRM) or NIST/EPA approved } \\
\text { gas manufacturer's certified reference material (CRM) following EPA } \\
\text { Traceability Protocol Number 1", as part of the specification for } \\
\text { evaluating the acceptability of SO2 and NOX continuous emission } \\
\text { monitoring systems (CEMS) at the time of installation or soon after } \\
\text { and whenever specified in the regulations. This is stated as part of the } \\
\text { Specifications and Test Procedures for SO2 and NOX Continuous } \\
\text { Emission Monitoring Systems in Stationary Sources. }\end{array}$ & EPA & $\begin{array}{l}\text { 40CFR } 60 \\
\text { AppendixB } \\
2.16 .2 .4\end{array}$ \\
\hline $\begin{array}{l}\text { SRM } \\
\text { 930D }\end{array}$ & $\begin{array}{l}\text { States that an attenuator used to check the daily calibration drift and } \\
\text { calibration error of a COMS can be designated as a primary if } \\
\text { calibrated on a 6-month frequency through the assignment of a } \\
\text { luminous transmittance value where the spectrophotometer calibration } \\
\text { has been verified through use of a NIST 930D Standard Reference } \\
\text { Material (SRM). This is stated as part of the performance } \\
\text { specifications for Standards of Performance for New Stationary } \\
\text { Sources. }\end{array}$ & EPA & $\begin{array}{l}\text { 40CFR } 60 \\
\text { AppendixB } \\
1.7 .1(2)(\mathrm{i})\end{array}$ \\
\hline
\end{tabular}




\begin{tabular}{|c|c|c|c|}
\hline SRM & $\begin{array}{l}\text { Defines Standard reference material or SRM as "a calibration gas } \\
\text { mixture issued and certified by NIST as having specific known } \\
\text { chemical or physical property values." }\end{array}$ & EPA & 40 CFR 72.2 \\
\hline SRM & $\begin{array}{l}\text { Defines Standard reference material-equivalent compressed gas } \\
\text { primary reference material (SRM-equivalent PRM) as "those gas } \\
\text { mixtures listed in a declaration of equivalence in accordance with } \\
\text { section } 2.1 .2 \text { of the "EPA Traceability Protocol for Assay and } \\
\text { Certification of Gaseous Calibration Standards," September 1997, } \\
\text { EPA-600/R-97/121." }\end{array}$ & EPA & 40 CFR 72.2 \\
\hline SRM & $\begin{array}{l}\text { Reference is made to NIST SRMs as a source of calibration gases as } \\
\text { part of the specifications and test procedures for continuous emissions } \\
\text { monitoring }\end{array}$ & EPA & $\begin{array}{l}\text { 40 CFR 75, } \\
\text { Appendix A } \\
5.1 .2\end{array}$ \\
\hline $\begin{array}{l}\text { Reference } \\
\text { Material }\end{array}$ & $\begin{array}{l}\text { Reference is made to a NIST OU as a source of list of vendors and } \\
\text { cylinder gases for SRM-Equivalent Compressed Gas Primary } \\
\text { Reference Material (PRM) as part of the specifications and test } \\
\text { procedures for continuous emissions monitoring }\end{array}$ & EPA & $\begin{array}{l}\text { 40 CFR 75, } \\
\text { Appendix A } \\
5.1 .1\end{array}$ \\
\hline SRM/RM & $\begin{array}{l}\text { Reference is made to analysis of NBS SRM } 1876 \text { and RM } 8410 \text { as a } \\
\text { measure of accuracy and comparability. This analysis has to be } \\
\text { conducted at least once per analyst per year as a quality control/quality } \\
\text { assurance procedure to be performed along with the sample analysis as } \\
\text { indicators that the materials used are adequate and the operations are } \\
\text { within acceptable limits. This is part of the requirements listed under } \\
\text { "Interim Transmission Electron Microscopy Analytical Methods- } \\
\text { Mandatory and Nonmandatory - and Mandatory Section to Determine } \\
\text { Completion of Response Actions" as a mandatory Transmission } \\
\text { Electron Microscopy method for asbestos related } \\
\text { analyses.(MANDATORY) }\end{array}$ & EPA & $\begin{array}{l}40 \text { CFR } 763 \\
\text { (II.)(I) Table III. }\end{array}$ \\
\hline SRM/RM & $\begin{array}{l}\text { Reference is made to analysis of NBS SRM } 1876 \text { and RM } 8411 \text { as a } \\
\text { measure of accuracy and comparability. This analysis has to be } \\
\text { conducted at least once per analyst per year as a quality control/quality } \\
\text { assurance procedure to be performed along with the sample analysis as } \\
\text { indicators that the materials used are adequate and the operations are } \\
\text { within acceptable limits. This is part of the requirements listed under } \\
\text { "Interim Transmission Electron Microscopy Analytical Methods- } \\
\text { Mandatory and Nonmandatory - and Mandatory Section to Determine } \\
\text { Completion of Response Actions" as a non-mandatory Transmission } \\
\text { Electron Microscopy method for asbestos related analyses. }\end{array}$ & EPA & $\begin{array}{l}40 \text { CFR } 763 \\
\text { (III.)(K) Table } \\
\text { III. }\end{array}$ \\
\hline
\end{tabular}




\begin{tabular}{|c|c|c|c|}
\hline $\begin{array}{l}\text { JCPDS- } \\
\text { ICDD }\end{array}$ & $\begin{array}{l}\text { Reference is made to the standard reference powder diffraction } \\
\text { patterns contained in "JCPDS-International Center for Diffraction } \\
\text { Data Powder Diffraction File, U.S. Department of Commerce, } \\
\text { National Bureau of Standards, and Joint Committee on Powder } \\
\text { Diffraction Studies, Swarthmore, PA", against which all samples that } \\
\text { exhibit diffraction peaks in the diagnostic regions for asbestiform } \\
\text { minerals are submitted to a full }\left(5^{\circ}-60^{\circ} 2 \Theta ; 1^{\circ} 2 \Theta / m i n\right) \text { qualitative } \\
\text { XRD scan, and their diffraction patterns are compared to verify initial } \\
\text { peak assignments and to identify possible matrix interferences when } \\
\text { subsequent quantitative analysis will be performed. This is required } \\
\text { when X-ray powder diffraction is used as an interim method for } \\
\text { determination of asbestos in bulk insulation samples for testing of } \\
\text { asbestos containing materials in schools. }\end{array}$ & EPA & $\begin{array}{l}40 \text { CFR } 763 \\
\text { Appendix E } 2.10 \\
\text { Ref. } 3\end{array}$ \\
\hline $\begin{array}{l}\text { NBS } \\
\text { Lead-in- } \\
\text { fuel } \\
\text { reference } \\
\text { standard }\end{array}$ & $\begin{array}{l}\text { It is required that "quality control standards, such as NBS standard } \\
\text { reference materials, should be analyzed at least once every testing } \\
\text { session" when testing of lead in gasoline by X-ray spectrometry } \\
\text { (MANDATORY). }\end{array}$ & EPA & $\begin{array}{l}40 \text { CFR } 80 \text { - } \\
\text { Appendix B } \\
\text { (Subpart J); } \\
\text { Method 3, } 7.4\end{array}$ \\
\hline SRM & $\begin{array}{l}\text { Gas specifications: States that calibration gases used in Gaseous } \\
\text { Exhaust Test Procedures for Emission Regulations for New (model } \\
\text { years } 1979 \text { and later) Gasoline-Fueled and Diesel-Fueled Heavy-Duty } \\
\text { Engines are to have "calibration gas values derived from NBS } \\
\text { "Standard Reference Materials" (SRMs) or other gas standards } \\
\text { approved by the Administrator. The uncertainty of the assigned } \\
\text { calibration gas values shall not exceed } 2.0 \text { percent of the assigned } \\
\text { value. The uncertainty is defined as the sum of the precision errors (at } \\
\text { the } 90 \text { percent confidence level) and the bias errors. Precision and bias } \\
\text { errors apply to both the equipment and the derivation procedures." }\end{array}$ & EPA & $\begin{array}{l}40 \text { CFR } 86.308- \\
79 \text { (b) }\end{array}$ \\
\hline
\end{tabular}




\begin{tabular}{|c|c|c|c|}
\hline SRM & $\begin{array}{l}\text { Gas specifications: States that span gases used in Gaseous Exhaust } \\
\text { Test Procedures for Emission Regulations for New (model years } 1979 \\
\text { and later) Gasoline-Fueled and Diesel-Fueled Heavy-Duty Engines are } \\
\text { to have "Span gas values derived from NBS "Standard Reference } \\
\text { Materials" (SRMs) or other gas standards approved by the } \\
\text { Administrator. The uncertainty of the assigned calibration gas values } \\
\text { shall not exceed } 3.0 \text { percent of the assigned value. The uncertainty is } \\
\text { defined as the sum of the precision errors (at the } 90 \text { percent confidence } \\
\text { level) and the bias errors. Precision and bias errors apply to both the } \\
\text { equipment and the derivation procedures". }\end{array}$ & EPA & $\begin{array}{l}40 \text { CFR } 86.308- \\
79(\mathrm{c})\end{array}$ \\
\hline SRM & $\begin{array}{l}\text { Requires that "calibration gas values are to be derived from NIST } \\
\text { "Standard Reference Materials" (SRMs) and are to be single blends as } \\
\text { specified.." This requirement for analytical gases is included in the } \\
\text { emission test equipment provisions for control of emissions from } \\
\text { nonroad spark-ignition engines at or below 19kW. }\end{array}$ & EPA & $\begin{array}{l}40 \text { CFR } \\
90.312(\mathrm{c})(1)\end{array}$ \\
\hline SRM & $\begin{array}{l}\text { This regulation states that "the true concentration of a span gas must } \\
\text { be within } \pm \text { two percent of the NIST gas standard. The true } \\
\text { concentration of a calibration gas must be within } \pm \text { one percent of the } \\
\text { NIST gas standard". This requirement for analytical gases is included } \\
\text { in the emission test equipment provisions for control of emissions } \\
\text { from nonraod spark-ignition engines at or below } 19 \mathrm{~kW} \text {. }\end{array}$ & EPA & $\begin{array}{l}40 \text { CFR } \\
90.312(\mathrm{c})(3)\end{array}$ \\
\hline SRM & $\begin{array}{l}\text { Specifies requirements for calibration gases, as part of emission test } \\
\text { equipment provisions for control of emissions from nonroad spark- } \\
\text { ignition engines at or below } 19 \mathrm{~kW} \text {. Requires the selection of "a } \\
\text { calibration gas (a span gas may be used for calibrating the CO2 } \\
\text { analyzer) with a concentration between the two lowest non-zero gas } \\
\text { divider increments. This gas must be "named" to an accuracy of } \pm \text { one } \\
\text { percent of NIST gas standards or other standards approved by the } \\
\text { Administrator". }\end{array}$ & EPA & $\begin{array}{c}40 \mathrm{CFR} \\
90.314(\mathrm{c})\end{array}$ \\
\hline SRM & $\begin{array}{l}\text { This regulation states that for calibration gases used in emission test } \\
\text { equipment for control of emissions from marine spark-ignition } \\
\text { engines, the "calibration gas values are to be derived from NIST } \\
\text { "Standard Reference Materials" (SRMs) or other local gas standards } \\
\text { and are to be single blends as specified...". }\end{array}$ & EPA & $\begin{array}{l}40 \text { CFR } \\
91.312(\mathrm{c})(1)\end{array}$ \\
\hline
\end{tabular}




\begin{tabular}{|c|c|c|c|}
\hline SRM & $\begin{array}{l}\text { This regulation states that for calibration gases used in emission test } \\
\text { equipment for control of emissions from marine spark-ignition engines } \\
\text { that "the true concentration of a span gas must be within } \pm 2 \text { percent of } \\
\text { the NIST gas standard. The true concentration of a calibration gas } \\
\text { must be within } \pm 1 \text { percent of the NIST gas standard" } \\
\text { (MANDATORY). }\end{array}$ & EPA & $\begin{array}{l}40 \text { CFR } \\
91.312(\mathrm{c})(3)\end{array}$ \\
\hline NBS 378 & $\begin{array}{l}\text { Requires that oil furnace black (NBS 378) used in the formulation of } \\
\text { rubber compound standard styrene butadiene rubber (SBR) brake cups, } \\
\text { should have properties identical with those supplied by the NBS } \\
\text { DOES NOT STATE WHAT KIND OF NBS PRODUCT (e.g., SRM, } \\
\text { RM, etc?) }\end{array}$ & DOT/NHTSA & $\begin{array}{l}\text { 49 CFR } 571.116 \\
\text { S7.6 }\end{array}$ \\
\hline NBS 370 & $\begin{array}{l}\text { Requires that zinc oxide (NBS 370)used in the formulation of rubber } \\
\text { compound standard styrene butadiene rubber (SBR) brake cups, } \\
\text { should have properties identical with those supplied by the NBS } \\
\text { DOES NOT STATE WHAT KIND OF NBS PRODUCT (e.g., SRM, } \\
\text { RM, etc?) }\end{array}$ & DOT/NHTSA & $\begin{array}{l}49 \text { CFR } 571.116 \\
\text { S7.6 }\end{array}$ \\
\hline NBS 371 & $\begin{array}{l}\text { Requires that sulfur (NBS 371)used in the formulation of rubber } \\
\text { compound standard styrene butadiene rubber (SBR) brake cups, } \\
\text { should have properties identical with those supplied by the NBS } \\
\text { DOES NOT STATE WHAT KIND OF NBS PRODUCT (e.g., SRM, } \\
\text { RM, etc?) }\end{array}$ & DOT/NHTSA & $\begin{array}{l}49 \text { CFR } 571.116 \\
\text { S7.6 }\end{array}$ \\
\hline NBS 372 & $\begin{array}{l}\text { Requires that stearic acid (NBS 372) used in the formulation of rubber } \\
\text { compound standard styrene butadiene rubber (SBR) brake cups, } \\
\text { should have properties identical with those supplied by the NBS } \\
\text { DOES NOT STATE WHAT KIND OF NBS PRODUCT (e.g., SRM, } \\
\text { RM, etc?) }\end{array}$ & DOT/NHTSA & $\begin{array}{l}49 \text { CFR } 571.116 \\
\text { S7.6 }\end{array}$ \\
\hline NBS 384 & $\begin{array}{l}\text { Requires that n-tertiary butyl-2-benzothiazole sulfenamide (NBS } \\
\text { 384)used in the formulation of rubber compound standard styrene } \\
\text { butadiene rubber (SBR) brake cups, should have properties identical } \\
\text { with those supplied by the NBS DOES NOT STATE WHAT KIND OF } \\
\text { NBS PRODUCT (e.g., SRM, RM, etc?) }\end{array}$ & DOT/NHTSA & $\begin{array}{l}\text { 49 CFR } 571.116 \\
\text { S7.6 }\end{array}$ \\
\hline
\end{tabular}




\section{References to NIST and NBS Special Publications in the Code of Federal Regulations}

\begin{tabular}{|c|c|c|c|c|}
\hline $\begin{array}{l}\text { Document } \\
\text { Number }\end{array}$ & Title of Document & $\begin{array}{l}\text { Edition } \\
\text { Date }\end{array}$ & $\begin{array}{l}\text { Incorporated } \\
\text { By }\end{array}$ & $\begin{array}{l}\text { Location in } \\
\text { CFR }\end{array}$ \\
\hline $\begin{array}{l}\text { SP 500- } \\
172\end{array}$ & $\begin{array}{l}\text { Reference is made to NIST SP 500-172 "Computer Security Training Guidelines" as a } \\
\text { source of information for providing training for employees responsible for the } \\
\text { management or use of computer systems that process sensitive information. }\end{array}$ & & OPM & $\begin{array}{c}5 \text { CFR } \\
930.302\end{array}$ \\
\hline SP 250 & $\begin{array}{l}\text { This regulation states that "NIST Special Publication 250, "Calibration and Related } \\
\text { Measurement Services of the National Institute of Standards \& Technology" is hereby } \\
\text { incorporated by reference, pursuant to } 5 \text { U.S.C. 552(a)(1) and 1 CFR Part 51. SP } 250 \\
\text { states the authority under which NIST performs various types of measurement services } \\
\text { including calibrations and tests and charges fees therefore, states the general conditions } \\
\text { under which the public may secure such services, describes these services in } \\
\text { considerable detail, and lists the fees to be charged, and sets out the instructions for } \\
\text { requesting them in an appendix which is reviewed, revised and reissued semi-annually } \\
\text { (December and June). The Director, Office of the Federal Register, approved the } \\
\text { incorporation by reference on December } 28,1967 . "\end{array}$ & NDG & DOC/NIST & $\begin{array}{c}15 \text { CFR } \\
200.115 \text { (a) }\end{array}$ \\
\hline SP 260 & $\begin{array}{l}\text { This regulation provides a description of NIST Special Publication 260, "Catalog of } \\
\text { NIST Standard Reference Materials," and specifies that SP260 and its supplements are } \\
\text { incorporated by reference pursuant to } 5 \text { U.S.C. 552(a)(1) and } 1 \text { CFR Part } 51\end{array}$ & NDG & DOC/NIST & $\begin{array}{c}15 \text { CFR } \\
230.7(a)\end{array}$ \\
\hline $\begin{array}{l}\text { NBS } \\
\text { Special } \\
\text { Pub }\end{array}$ & $\begin{array}{l}\text { Ross, M. The Asbestos Minerals: Definitions, Description, Modes of } \\
\text { Formation, Physical and Chemical Properties and Health Risk to the Mining } \\
\text { Community, Nation Bureau of Standards Special Publication, Washington, } \\
\text { DC, 1977, is referred to in the description of the method performance of the } \\
\text { Polarized Light Microscopy of Asbestos (Non-Mandatory) under the safety } \\
\text { and health regulations for construction. }\end{array}$ & 1977 & DOL/OSHA & $\begin{array}{l}29 \text { CFR } \\
1926.1101 \\
\text { Appendix K } \\
5.9\end{array}$ \\
\hline $\begin{array}{l}\text { NBS SP } \\
442\end{array}$ & $\begin{array}{l}\text { NBS SP } 442 \text { "Giam, C.S., and Chan, H.S. "Control of Blanks in the Analysis of } \\
\text { Phthalates in Air and Ocean Biota Samples," U.S. National Bureau of Standards, } \\
\text { Special Publication 442, pp. 701-708, 1976" is referred to in specifying Method } 606 \\
\text { which is applicable for determination of certain phthalate esters as one of the Methods } \\
\text { for Organic Chemical Analysis of Municipal and Industrial Wastewater }\end{array}$ & 1976 & EPA & $\begin{array}{l}\text { 40 CFR } 136 \\
\text { Appendix A } \\
\text { Method } 606\end{array}$ \\
\hline
\end{tabular}




\begin{tabular}{|c|c|c|c|c|}
\hline $\begin{array}{l}\text { NBS SP } \\
442\end{array}$ & $\begin{array}{l}\text { NBS SP } 442 \text { "Giam, C.S., and Chan, H.S. "Control of Blanks in the Analysis } \\
\text { of Phthalates in Air and Ocean Biota Samples," U.S. National Bureau of } \\
\text { Standards, Special Publication 442, pp. 701-708, 1976" is referred to in } \\
\text { specifying Method } 608 \text { which is applicable for determination of certain } \\
\text { organochlorines and PCBs as one of the Methods for Organic Chemical } \\
\text { Analysis of Municipal and Industrial Wastewater }\end{array}$ & 1976 & EPA & $\begin{array}{l}40 \text { CFR } 136 \\
\text { Appendix A } \\
\text { Method } 608\end{array}$ \\
\hline $\begin{array}{l}\text { NBS SP } \\
506\end{array}$ & $\begin{array}{l}\text { Reference is made to "J. B. Krause and W. H. Ashton, Misidentification of asbestos in } \\
\text { talc, pp. 339-353, in: Proceedings of Workshop on Asbestos: Definitions and } \\
\text { Measurement Methods (NBS Special Publication 506), C. C. Gravatt, P. D. LaFleur, } \\
\text { and K. F. Heinrich (eds.), Washington, DC: National Measurement Laboratory, } \\
\text { National Bureau of Standards, } 1977 \text { (issued 1978)" to elucidate possible reasons for } \\
\text { interferences in XRD analyses of asbestiform materials, and related specimen } \\
\text { preparation. This is in the context of X-ray powder diffraction being used as an } \\
\text { interim method for determination of asbestos in bulk insulation samples for testing of } \\
\text { asbestos containing materials in schools. }\end{array}$ & 1978 & EPA & $\begin{array}{l}40 \text { CFR } 763 \\
\text { Appendix E } \\
2.10 \text { Ref. } 11\end{array}$ \\
\hline $\begin{array}{l}\text { NBS SP } \\
506\end{array}$ & $\begin{array}{l}\text { Reference is made to "H. D. Stanley, The detection and identification of asbestos and } \\
\text { asbesti-form minerals in talc, pp. 325-337, in Proceedings of Workshop on Asbestos: } \\
\text { Definitions and Measurement Methods (NBS Special Publication 506), C. C. Gravatt, } \\
\text { P. D. LaFleur, and K. F. Heinrich (eds.), Washington, DC, National Measurement } \\
\text { Laboratory, National Bureau of Standards, } 1977 \text { (issued 1978)" in explaining the } \\
\text { difficulties associated with definitive identification of the asbestos minerals by } \\
\text { comparison with standard reference diffraction patterns due to alterations in the crystal } \\
\text { lattice associated with differences in isomorphous substitution and degree of } \\
\text { crystallinity, particularly for the amphiboles. This is in the context of X-ray powder } \\
\text { diffraction being used as an interim method for determination of asbestos in bulk } \\
\text { insulation samples for testing of asbestos containing materials in schools. }\end{array}$ & 1978 & EPA & $\begin{array}{l}42 \text { CFR } 763 \\
\text { Appendix E } \\
2.10 \text { Ref. } 12\end{array}$ \\
\hline
\end{tabular}




\begin{tabular}{|c|c|c|c|c|}
\hline $\begin{array}{l}\text { NBS SP } \\
506\end{array}$ & $\begin{array}{l}\text { Reference is made to "J. C. Haartz, B. A. Lange, R. G. Draftz, and R. F. Scholl, } \\
\text { Selection and characterization of fibrous and nonfibrous amphiboles for analytical } \\
\text { methods development, pp. 295-312, in: Proceedings of Workshop on Asbestos: } \\
\text { Definitions and Measurement Methods (NBS Special Publication 506), C. C. Gravatt, } \\
\text { P. D. LaFleur, and K. F. Heinrich (eds.), Washington, DC: National Measurement } \\
\text { Laboratory, National Bureau of Standards, } 1977 \text { (issued 1978)" to underscore the } \\
\text { problem of obtaining and characterizing suitable reference materials for asbestos } \\
\text { analysis. Though such analytical reference materials maybe available, it is believed } \\
\text { that they are not available in large quantities for routine analyses. This is in the context } \\
\text { of X-ray powder diffraction being used as an interim method for determination of } \\
\text { asbestos in bulk insulation samples for testing of asbestos containing materials in } \\
\text { schools. }\end{array}$ & 1978 & EPA & $\begin{array}{l}43 \text { CFR } 763 \\
\text { Appendix E } \\
2.10 \text { Ref. } 17\end{array}$ \\
\hline $\begin{array}{l}\text { NBS SP } \\
440\end{array}$ & $\begin{array}{l}\text { This subpart incorporates by reference "The Universal Color Language" and "The } \\
\text { Color Names Dictionary" in Color: Universal Language and Dictionary of Names, } \\
\text { National Bureau of Standards Special Publication } 440 \text { for specifications pertaining to } \\
\text { Buoyant Apparatus for Merchant Vessels to be used as life saving equipment }\end{array}$ & 1976 & DHS/USCG & $\begin{array}{c}\text { 46 CFR } \\
160.010-1\end{array}$ \\
\hline $\begin{array}{l}\text { NBS SP } \\
440\end{array}$ & $\begin{array}{l}\text { This subpart incorporates by reference "The Universal Color Language" and "The } \\
\text { Color Names Dictionary" in Color: Universal Language and Dictionary of Names, } \\
\text { National Bureau of Standards Special Publication } 440 \text { for specifications pertaining to } \\
\text { Hand Red Flare Distress Signals to be used as life saving equipment. }\end{array}$ & 1976 & DHS/USCG & $\begin{array}{l}46 \text { CFR } \\
160.021-1\end{array}$ \\
\hline $\begin{array}{l}\text { NBS } \\
\text { SP440 }\end{array}$ & $\begin{array}{l}\text { Reference is made to NBS publication "Color Names Dictionary" to define the colors } \\
\text { in tests for chromaticity of Hand Red Flare Distress Signals to be used as life saving } \\
\text { equipment. }\end{array}$ & 1976 & DHS/USCG & $\begin{array}{l}46 \mathrm{CFR} \\
160.021- \\
4(\mathrm{~d})(7)\end{array}$ \\
\hline $\begin{array}{l}\text { NBS SP } \\
440\end{array}$ & $\begin{array}{l}\text { This subpart incorporates by reference "The Color Names Dictionary" in Color: } \\
\text { Universal Language and Dictionary of Names, National Bureau of Standards Special } \\
\text { Publication 440, December 1976, for specifications pertaining to Floating Orange } \\
\text { Smoke Distress Signals ( } 5 \text { Minutes) to be used as lifesaving equipment. }\end{array}$ & 1976 & DHS/USCG & $\begin{array}{c}46 \text { CFR } \\
160.022-1\end{array}$ \\
\hline $\begin{array}{l}\text { NBS SP } \\
440\end{array}$ & $\begin{array}{l}\text { Reference is made to NBS publication "Color Names Dictionary" (colors 34-39 and } \\
48-54 \text { ) to define the specifications for orange color of smoke for Floating Orange } \\
\text { Smoke Distress Signals ( } 5 \text { Minutes) to be used as lifesaving equipment. }\end{array}$ & 1976 & DHS/USCG & $\begin{array}{l}46 \text { CFR } \\
160.022-4 \\
\text { (d)(7) }\end{array}$ \\
\hline $\begin{array}{l}\text { NBS SP } \\
440\end{array}$ & $\begin{array}{l}\text { This subpart incorporates by reference "The Universal Color Language" and "The } \\
\text { Color Names Dictionary" in Color: Universal Language and Dictionary of Names, } \\
\text { National Bureau of Standards Special Publication 440, Dictionary 1976, for } \\
\text { specifications pertaining to Pistol-Projected Parachute Red Flare Distress Signals to be } \\
\text { used as lifesaving equipment. }\end{array}$ & 1976 & DHS/USCG & $\begin{array}{c}46 \text { CFR } \\
160.024-1\end{array}$ \\
\hline
\end{tabular}




\begin{tabular}{|c|c|c|c|c|}
\hline $\begin{array}{l}\text { NBS } \\
\text { SP440 }\end{array}$ & $\begin{array}{l}\text { Reference is made to NBS publication "Color Names Dictionary" to define the colors } \\
\text { in tests for chromaticity of Pistol-Projected Parachute Red Flare Distress Signals to be } \\
\text { used as lifesaving equipment. }\end{array}$ & 1976 & DHS/USCG & $\begin{array}{l}46 \mathrm{CFR} \\
160.024- \\
4(d)(4)\end{array}$ \\
\hline $\begin{array}{l}\text { NBS SP } \\
440\end{array}$ & $\begin{array}{l}\text { This subpart incorporates by reference "The Universal Color Language" and "The } \\
\text { Color Names Dictionary" in Color: Universal Language and Dictionary of Names, } \\
\text { National Bureau of Standards Special Publication 440, December 1976, for } \\
\text { specifications pertaining to Hand-Held Rocket-Propelled Parachute Red Flare Distress } \\
\text { Signals to be used as life saving equipment. }\end{array}$ & 1976 & DHS/USCG & \\
\hline $\begin{array}{l}\text { NBS SP } \\
440\end{array}$ & $\begin{array}{l}\text { This subpart incorporates by reference "The Universal Color Language" and "The } \\
\text { Color Names Dictionary" in Color: Universal Language and Dictionary of Names, } \\
\text { National Bureau of Standards Special Publication 440, December 1976, for } \\
\text { specifications pertaining to Hand Orange Smoke Distress Signals to be used as life } \\
\text { saving equipment. }\end{array}$ & 1976 & DHS/USCG & $\begin{array}{c}46 \text { CFR } \\
160.037-1\end{array}$ \\
\hline $\begin{array}{l}\text { NBS SP } \\
440\end{array}$ & $\begin{array}{l}\text { This subpart incorporates by reference "The Color Names Dictionary" in Color: } \\
\text { Universal Language and Dictionary of Names, National Bureau of Standards Special } \\
\text { Publication 440, December } 1976 \text { for specifications pertaining to Floating Orange } \\
\text { Smoke Distress Signal (15 minutes) in use as lifesaving equipment. }\end{array}$ & 1976 & DHS/USCG & $\begin{array}{l}46 \text { CFR } \\
160.057- \\
1(a)(1)\end{array}$ \\
\hline $\begin{array}{l}\text { NBS SP } \\
440\end{array}$ & $\begin{array}{l}\text { Reference is made to NBS publication "Color Names Dictionary" (colors 34-39 and } \\
48-54 \text { ) to define the specifications for orange color of smoke for Floating Orange } \\
\text { Smoke Distress Signals ( } 15 \text { Minutes) to be used as lifesaving equipment. }\end{array}$ & 1976 & DHS/USCG & $\begin{array}{l}46 \text { CFR } \\
160.057- \\
4(d)(8)\end{array}$ \\
\hline $\begin{array}{l}\text { NBS SP } \\
440\end{array}$ & $\begin{array}{l}\text { This subpart incorporates by reference, "The Universal Color Language" and "The } \\
\text { Color Names Dictionary" in Color: Universal Language and Dictionary of Names, } \\
\text { National Bureau of Standards Special Publication 440, for specifications pertaining to } \\
\text { Hybrid Inflatable Personal Flotation Devices in use as life saving equipment. }\end{array}$ & 1976 & DHS/USCG & $\begin{array}{c}46 \text { CFR } \\
160.077-5\end{array}$ \\
\hline $\begin{array}{l}\text { NBS SP } \\
440\end{array}$ & $\begin{array}{l}\text { This subpart incorporates by reference NBS Special Publication } 440 \text { Color: } \\
\text { Universal Language and Dictionary of Names, 1976, for specifications pertaining to } \\
\text { Inflatable Liferafts (SOLAS) in use as lifesaving equipment. }\end{array}$ & 1976 & DHS/USCG & $\begin{array}{c}46 \text { CFR } \\
160.151-5\end{array}$ \\
\hline $\begin{array}{l}\text { NBS SP } \\
440\end{array}$ & $\begin{array}{l}\text { This regulation refers to NBS SP 440, to define the color of the canopy required for } \\
\text { inflatable liferafts (SOLAS) in use as lifesaving equipment. The particular color } \\
\text { referred to is color } 34 \text { in SP } 440\end{array}$ & 1976 & DHS/USCG & $\begin{array}{l}46 \text { CFR } \\
160.151- \\
15(e)\end{array}$ \\
\hline $\begin{array}{l}\text { NBS SP } \\
440\end{array}$ & $\begin{array}{l}\text { NBS SP } 440 \text { is referred to by the statement that "The primary color of the appendages } \\
\text { must be vivid reddish orange (color number } 34 \text { of NBS Special Publication 440), or a } \\
\text { fluorescent color of a similar hue" to define the requirements that appendages on } \\
\text { inflatable liferafts (SOLAS) should meet to resist capsizing from winds and waves. }\end{array}$ & 1976 & DHS/USCG & $\begin{array}{l}46 \text { CFR } \\
160.151- \\
17(a)(2)(\text { vii })\end{array}$ \\
\hline
\end{tabular}




\begin{tabular}{|c|c|c|c|c|}
\hline $\begin{array}{l}\text { NBS SP } \\
440\end{array}$ & $\begin{array}{l}\text { This subpart incorporates by reference National Bureau of Standards Special } \\
\text { Publication } 440 \text { - Color, Universal Language and Dictionary of Names; December } \\
\text { 1976, as part of the definition of specification for immersion suits in use as lifesaving } \\
\text { equipment. }\end{array}$ & 1976 & DHS/USCG & $\begin{array}{l}46 \text { CFR } \\
160.171-3\end{array}$ \\
\hline $\begin{array}{l}\text { NBS SP } \\
440\end{array}$ & $\begin{array}{l}\text { This subchapter refers to NBS SP } 440 \text { to specify the requirements for the primary color } \\
\text { of the exterior surface of each thermal protective aid ( vivid reddish orange, color } \\
\text { number } 34 \text { of National Bureau of Standards Publication } 440 \text { ). This forms part of the } \\
\text { requirements for immersion suits used as lifesaving equipment. }\end{array}$ & 1976 & DHS/USCG & $\begin{array}{l}46 \text { CFR } \\
160.171-9(h)\end{array}$ \\
\hline $\begin{array}{l}\text { NBS SP } \\
440\end{array}$ & $\begin{array}{l}\text { This subpart incorporates by reference National Bureau of Standards Special } \\
\text { Publication } 440 \text { - Color, Universal Language and Dictionary of Names, for } \\
\text { specifications pertaining to thermal protective aids used as lifesaving equipment. }\end{array}$ & & DHS/USCG & $\begin{array}{l}46 \text { CFR } \\
160.174-3(f)\end{array}$ \\
\hline $\begin{array}{l}\text { NBS SP } \\
440\end{array}$ & $\begin{array}{l}\text { This subchapter refers to NBS SP } 440 \text { to specify the requirements for the primary color } \\
\text { of the exterior surface of each thermal protective aid ( vivid reddish orange, color } \\
\text { number } 34 \text { of National Bureau of Standards Publication } 440 \text { ). This forms part of the } \\
\text { requirements for thermal protective aids used as lifesaving equipment. }\end{array}$ & & DHS/USCG & $\begin{array}{l}46 \text { CFR } \\
160.174-9(h)\end{array}$ \\
\hline $\begin{array}{l}\text { NBS SP } \\
440\end{array}$ & $\begin{array}{l}\text { This subpart incorporates by reference Special Pub. 440, Color: Universal Language } \\
\text { and Dictionary of Names; "The Universal Color Language" and "The Color Names } \\
\text { Dictionary", 1976-160.176-9, for specifications pertaining to inflatable lifejackets in } \\
\text { use as lifesaving equipment. }\end{array}$ & & DHS/USCG & $\begin{array}{l}46 \text { CFR } \\
160.176-4\end{array}$ \\
\hline $\begin{array}{l}\text { NBS SP } \\
440\end{array}$ & $\begin{array}{l}\text { Reference is made to NBS SP } 440 \text { to define the amongst the general features of } \\
\text { inflatable lifejackets, the color on the external surfaces as being "primarily vivid } \\
\text { reddish orange as defined by sections } 13 \text { and } 14 \text { of the "Color Names Dictionary.." }\end{array}$ & 1976 & DHS/USCG & $\begin{array}{l}46 \text { CFR } \\
160.176- \\
9(a)(10)\end{array}$ \\
\hline $\begin{array}{l}\text { NBS SP } \\
440\end{array}$ & $\begin{array}{l}\text { This part incorporates by reference NBS Special Pub. } 440 \text { "Color: Universal } \\
\text { Language and Dictionary of Names", } 1976\end{array}$ & 1976 & DHS/USCG & $\begin{array}{l}46 \text { CFR } \\
169.115(\mathrm{c})(2)\end{array}$ \\
\hline
\end{tabular}


Appendix 8

References to NIST and NBS Publications (assorted) in the Code of Federal Regulations

\begin{tabular}{|c|c|c|c|c|}
\hline $\begin{array}{l}\text { Document } \\
\text { Number }\end{array}$ & Title of Document & $\begin{array}{l}\text { Edition } \\
\text { Date }\end{array}$ & $\begin{array}{l}\text { Incorporated } \\
\text { By }\end{array}$ & Location in CFR \\
\hline NIST $85-3273$ & $\begin{array}{l}\text { Reference is made to NIST Publication (NIST IR 85-3273) "Life Cycle } \\
\text { Costing Manual for Federal Energy Management Program" in stating } \\
\text { the methodological assumptions for "estimating and comparing the life } \\
\text { cycle costs of Federal buildings, for determining the life cycle cost } \\
\text { effectiveness of energy conservation measures and water conservation } \\
\text { measures, and for rank ordering life cycle cost effective measures in } \\
\text { order to design a new Federal building or to retrofit an existing Federal } \\
\text { building." }\end{array}$ & & $\begin{array}{l}\mathrm{DOE} / \text { Energy } \\
\text { Conservation }\end{array}$ & 10 CFR 436.14(a) \\
\hline $\begin{array}{l}\text { NIST test } \\
\text { procedures on } \\
\text { engine oil - } \\
\text { penalties }\end{array}$ & $\begin{array}{l}\text { Prohibited acts - A manufacturer or other seller may represent, on a } \\
\text { label on a container of processed used oil, that such oil is substantially } \\
\text { equivalent to new oil for use as engine oil only if the manufacturer has } \\
\text { determined that the oil is substantially equivalent to new oil for use as } \\
\text { engine oil in accordance with the NIST test procedures prescribed } \\
\text { under } \$ 311.4 \text { of this part, and has based the representation on that } \\
\text { determination(MANDATORY) }\end{array}$ & 1996 & FTC & 16 CFR 311.6 \\
\hline NBSIR 84-7833 & $\begin{array}{l}\text { Regulation refers to guidelines in NBSIR 84-2833 "Data requirements } \\
\text { for the Seismic Review of LNG facilities" to produce the required } \\
\text { report on earthquake hazards and engineering, "if the LNG } \\
\text { import/export facility is to be located at a site in zones 2, 3, or } 4 \text { of the } \\
\text { Uniform Building Code's Seismic Risk Map of the United States, or } \\
\text { where there is a risk of surface faulting or ground liquefaction" in filing } \\
\text { Applications for Authorization to Construct, Operate or Modify } \\
\text { Facilities Used for the Export or Import of Natural } \\
\text { Gas".(MANDATORY) }\end{array}$ & & FERC & 18 CFR 153.8(a)(6) \\
\hline $\begin{array}{l}\text { NBS DOC FF1- } \\
70\end{array}$ & $\begin{array}{l}\text { Standard test method for Flammability of Finished Textile Floor } \\
\text { Covering Materials - also available as ASTM D2859-76, incorporated } \\
\text { by reference -NBS standard has been stated under "Supplementary } \\
\text { specific procedural requirements under HUD building product } \\
\text { standards and certification program for carpet and carpet with attached } \\
\text { cushion". (mandatory) }\end{array}$ & 1970 & HUD & 24 CFR 200.942 \\
\hline
\end{tabular}




\begin{tabular}{|c|c|c|c|c|}
\hline $\begin{array}{l}\text { Reference } \\
\text { publications }\end{array}$ & $\begin{array}{l}\text { "Appendix B to } \S 1910.145(\mathrm{f}) \text { - References for Further Information } \\
\text { The following references provide information which can be helpful in } \\
\text { understanding the requirements contained in various sections of the } \\
\text { standard: ...... Glass, R.A. and others, Some Criteria for Colors and } \\
\text { Signs in Workplaces, National Bureau of Standards, Washington DC, } \\
\text { 1983.....5. Howett, G.L., Size of Letters Required for Visibility as a } \\
\text { Function of Viewing Distance and Observer Acuity, National Bureau of } \\
\text { Standards, Washington DC, July 1983....6. Lerner, N.D. and Collins, } \\
\text { B.L., The Assessment of Safety Symbol Understandability by Different } \\
\text { Testing Methods, National Bureau of Standards, Washington DC, } \\
\text { 1980.....7. Lerner, N.D. and Collins, B.L., Workplace Safety Symbols, } \\
\text { National Bureau of Standards, Washington DC, 1980....12. Symbols } \\
\text { for Industrial Safety, National Bureau of Standards, Washington DC, } \\
\text { April 1982." }\end{array}$ & $\begin{array}{l}1980- \\
1983\end{array}$ & DOL/OSHA & 29CFR 1910.145 \\
\hline $\begin{array}{l}\text { Publication on } \\
\text { fire alarms and } \\
\text { communication } \\
\text { systems }\end{array}$ & $\begin{array}{l}\text { I. Appendix general references. The following references provide } \\
\text { information which can be helpful in understanding the requirements } \\
\text { contained in all of the sections of subpart L: } \\
\text { J. Employee alarm systems: ... 8. Fire Alarm and Communication } \\
\text { Systems. National Bureau of Standards. Washington, D.C., April } 1978 \text {. }\end{array}$ & 1978 & DOL/OSHA & $\begin{array}{l}29 \text { CFR } 1910.165 \\
\text { Appendix C to Subpart } \\
\text { L }\end{array}$ \\
\hline $\begin{array}{l}\text { NBS Report } \\
\text { BSS-121 }\end{array}$ & $\begin{array}{l}\text { Reference is made to NBS Report BSS-121 as a source of definitions, } \\
\text { in part, related to classifying soil and rock deposits based on site and } \\
\text { environmental conditions, and on the structure and composition of the } \\
\text { earth deposits. This relates to regulations under the safety and health } \\
\text { regulations for construction. }\end{array}$ & & DOL/OSHA & $\begin{array}{l}29 \text { CFR } 1926 \text { Appendix } \\
\text { A(b) }\end{array}$ \\
\hline $\begin{array}{l}\text { NBS report on } \\
\text { shoring and } \\
\text { sloping of } \\
\text { trenches and } \\
\text { excavations }\end{array}$ & $\begin{array}{l}\text { Reference is made to National Bureau of Standards (NBS) report, } \\
\text { "Recommended Technical Provisions for Construction Practice in } \\
\text { Shoring and Sloping of Trenches and Excavations" for defining the } \\
\text { dimensions of timber members in the section on the basis and } \\
\text { limitations of data that can be used in timber shoring as a method of } \\
\text { preventing cave-ins in trenches that do not exceed 20ft. in depth. This } \\
\text { part is under the safety and health regulations for construction. }\end{array}$ & & DOL/OSHA & $\begin{array}{l}29 \text { CFR } 1926 \text { Appendix } \\
\text { C (d)(1)(i) }\end{array}$ \\
\hline
\end{tabular}




\begin{tabular}{|c|c|c|c|c|}
\hline $\begin{array}{l}\text { NBS Journal of } \\
\text { Research 86:361- } \\
366\end{array}$ & $\begin{array}{l}\text { States that the TSCA (Toxic Substances Control Act) partition } \\
\text { coefficient (n-octanol/water), generator column test method is based on } \\
\text { the DCCLC technique for determining the aqueous solubility of organic } \\
\text { compounds referred to in the NBS publication "DeVoe, H. et al. } \\
\text { "Generator Columns and High Pressure Liquid Chromatography for } \\
\text { Determining Aqueous Solubilities and Octanol-Water Partition } \\
\text { Coefficients of Hydrophobic Substances," Journal of Research of the } \\
\text { National Bureau of Standards, } 86: 361-366 \text { (1981)" . This regulation } \\
\text { states that product property test guidelines for identification of specific } \\
\text { chemical substance and mixture testing requirements. }\end{array}$ & 1981 & EPA & 40 CFR 799.6756(b)(3) \\
\hline $\begin{array}{l}\text { NBS Journal of } \\
\text { Research } 86: 361- \\
366\end{array}$ & $\begin{array}{l}\text { Refers to NBS publication "DeVoe, H. et al. "Generator Columns and } \\
\text { High Pressure Liquid Chromatography for Determining Aqueous } \\
\text { Solubilities and Octanol-Water Partition Coefficients of Hydrophobic } \\
\text { Substances," Journal of Research of the National Bureau of Standards, } \\
86: 361-366 \text { (1981)" to state how an accurate measurement of the } \\
\text { sample loop may be accomplished by using a spectrophotometric } \\
\text { method as part of the product property test guidelines for identification } \\
\text { of specific chemical substance and mixture testing requirements in } \\
\text { response to the TSCA. }\end{array}$ & 1981 & EPA & $\begin{array}{l}40 \text { CFR } \\
799.6756(\mathrm{c})(3)(\mathrm{iii})(\mathrm{C})(1)\end{array}$ \\
\hline $\begin{array}{l}\text { NBS Journal of } \\
\text { Research } 86: 361- \\
366\end{array}$ & $\begin{array}{l}\text { Refers to NBS publication "DeVoe, H. et al., Generator columns and } \\
\text { high pressure liquid chromatography for determining aqueous } \\
\text { solubilities and octanol-water partition coefficients of hydrophobic } \\
\text { substances. Journal of Research, National Bureau of Standards, } 86: 361- \\
366 \text { (1981)" to state how accurate measurements of a sample loop can } \\
\text { be accomplished when using spectrophotometric methods. The same } \\
\text { publication is also referred to define the principle of the test method } \\
\text { based on the dynamic coupled column liquid chromatographic } \\
\text { (DCCLC) technique for determining the aqueous solubility of organic } \\
\text { compounds". These references are in support of tests intended to meet } \\
\text { the testing requirements of the Toxic Substances Control Act (TSCA), } \\
\text { as part of the testing requirements for identification of specific chemical } \\
\text { substances and mixtures. }\end{array}$ & 1981 & EPA & 40 CFR 799.6786(e)(1) \\
\hline
\end{tabular}

\section{Appendix 8}




\begin{tabular}{|c|c|c|c|c|}
\hline NBS IR 81-2406 & $\begin{array}{l}\text { Reference is made to the NBS publication, "Wasik, S.P. et al., } \\
\text { Octanol/Water Partition Coefficient and Aqueous Solubilities of } \\
\text { Organic Compounds. NBS Report NBSIR 81-2406. Washington, DC: } \\
\text { National Bureau of Standards, U.S. Department of Commerce (1981)". } \\
\text { This publication is referred to define the "principle of the test method } \\
\text { based on the dynamic coupled column liquid chromatographic } \\
\text { (DCCLC) technique for determining the aqueous solubility of organic } \\
\text { compounds". Also, this reference has been used to obtain data for water } \\
\text { solubilities at } 25^{\circ} \mathrm{C} \text { for a number of reference chemicals and stated as } \\
\text { part of this regulation. These references are in support of tests intended } \\
\text { to meet the testing requirements of the Toxic Substances Control Act } \\
\text { (TSCA), as part of the testing requirements for identification of specific } \\
\text { chemical substances and mixtures. }\end{array}$ & & EPA & 40 CFR 799.6786(e)(11) \\
\hline NBSIR 81-2406 & $\begin{array}{l}\text { States that the TSCA (Toxic Substances Control Act) partition } \\
\text { coefficient (n-octanol/water), generator column test method is based on } \\
\text { the DCCLC technique for determining the aqueous solubility of organic } \\
\text { compounds referred to in the NBS publication "Wasik, S.P. et al. } \\
\text { Octanol/water partition coefficient and aqueous solubilities of organic } \\
\text { compounds, Report NBSIR } 81-2406 \text { (1981) National Bureau of } \\
\text { Standards, U.S. Department of Commerce, Washington, DC" . This } \\
\text { regulation states that product property test guidelines for identification } \\
\text { of specific chemical substance and mixture testing requirements in } \\
\text { response to the TSCA. }\end{array}$ & 1981 & EPA & 40 CFR 799.6756(b)(3) \\
\hline NBSIR 81-2406 & $\begin{array}{l}\text { Refers to the NBS publication "Wasik, S.P. et al. Octanol/water } \\
\text { partition coefficient and aqueous solubilities of organic compounds, } \\
\text { Report NBSIR 81-2406 (1981) National Bureau of Standards, U.S. } \\
\text { Department of Commerce, Washington, DC" as the source of } \\
\text { information on n-Octanol/Water Partition Coefficient at } 25^{\circ} \mathrm{C} \text { for some } \\
\text { reference compounds so that the generator column method can be } \\
\text { calibrated, and to allow the chemical laboratory the opportunity to } \\
\text { compare its results with these values. This regulation states that product } \\
\text { property test guidelines for identification of specific chemical substance } \\
\text { and mixture testing requirements. }\end{array}$ & 1981 & EPA & $\begin{array}{l}40 \text { CFR } \\
799.6756(\mathrm{~b})(4)(\mathrm{ii})\end{array}$ \\
\hline NBS publication & $\begin{array}{l}\text { Humidity Calculations - defines the saturation vapor pressure (PWB) of } \\
\text { water at the wet-bulb temperature using equation in an NBS } \\
\text { publication. (ed. Note: No information on what publication, except to } \\
\text { state editors of publication as Wexler, (A.), and Greenspan, (L.)) as part } \\
\text { of Gaseous Exhaust Test Procedures use in Emission Regulations for } \\
\text { New (in this case } 1979 \text { and later) Gasoline-Fueled and Diesel-Fueled } \\
\text { Heavy-Duty Engines. }\end{array}$ & & EPA & 40 CFR 86.344-79(d)(1) \\
\hline
\end{tabular}

\section{Appendix 8}




\begin{tabular}{|c|c|c|c|c|}
\hline $\begin{array}{l}\text { NBS Report } \\
4792\end{array}$ & $\begin{array}{l}\text { This subpart incorporates by reference "Development of a Laboratory } \\
\text { Test for Evaluation of the Effectiveness of Smoke Signals," National } \\
\text { Bureau of Standards Report } 4792 \text {, July 1956, for specifications } \\
\text { pertaining to Floating Orange Smoke Distress Signals (5 Minutes) to be } \\
\text { used as lifesaving equipment. }\end{array}$ & 1956 & DHS/USCG & 46 CFR $160.022-1$ \\
\hline $\begin{array}{l}\text { NBS Report } \\
4792\end{array}$ & $\begin{array}{l}\text { Reference is made to National Bureau of Standards Report No. } 4792 \text { to } \\
\text { define the apparatus to be used for determining the volume and density } \\
\text { of smoke in testing of Floating Orange Smoke Distress Signals ( } 5 \\
\text { Minutes) to be used as lifesaving equipment. }\end{array}$ & 1956 & DHS/USCG & $\begin{array}{l}46 \text { CFR 160.022-4 } \\
\text { (d)(8) }\end{array}$ \\
\hline $\begin{array}{l}\text { NBS Report } \\
4792\end{array}$ & $\begin{array}{l}\text { This subpart incorporates by reference "Development of a Laboratory } \\
\text { Test for Evaluation of the Effectiveness of Smoke Signals," National } \\
\text { Bureau of Standards Report } 4792 \text {, July } 1956 \text { for specifications } \\
\text { pertaining to Hand Orange Smoke Distress Signals to be used as life } \\
\text { saving equipment. }\end{array}$ & 1956 & DHS/USCG & 46 CFR 160.037-1 \\
\hline $\begin{array}{l}\text { NBS Report } \\
4792\end{array}$ & $\begin{array}{l}\text { This subpart refers to equipment described in "Development of a } \\
\text { Laboratory Test for Evaluation of the Effectiveness of Smoke Signals," } \\
\text { National Bureau of Standards Report } 4792, \text { July } 1956 \text { for specifications } \\
\text { pertaining to the volume and density of smoke for use in the technical } \\
\text { test specifications for testing of Hand Orange Smoke Distress Signals to } \\
\text { be used as life saving equipment. }\end{array}$ & 1956 & DHS/USCG & 46 CFR 160.037-4 \\
\hline $\begin{array}{l}\text { NBS Simplified } \\
\text { Practice } \\
\text { Recommendation } \\
\text { R178-41 }\end{array}$ & $\begin{array}{l}\text { Reference is made to the publication National Bureau of Standards } \\
\text { Simplified Practice Recommendation: No. R } 178-41 \text {, Packaging of } \\
\text { First-aid Unit Dressings and Treatments, as a source of applicable } \\
\text { specifications/publications for first-aid kits for merchant vessels. }\end{array}$ & & DHS/USCG & 46 CFR 160.041-1 \\
\hline $\begin{array}{l}\text { NBS Simplified } \\
\text { Practice } \\
\text { Recommendation } \\
\text { R178-41 }\end{array}$ & $\begin{array}{l}\text { Reference is made to the NBS Simplified Practice Recommendations } \\
\text { (R178-41) for Packaging of First-aid Unit Dressings and Treatments, to } \\
\text { define size of first-aid kits for merchant vessels to be used as life-saving } \\
\text { equipment. }\end{array}$ & & DHS/USCG & 46 CFR $160.041-2$ \\
\hline $\begin{array}{l}\text { NBS Simplified } \\
\text { Practice } \\
\text { Recommendation } \\
\text { R178-41 }\end{array}$ & $\begin{array}{l}\text { Reference is made to the NBS Simplified Practice Recommendations } \\
\text { (R178-41) for Packaging of First-aid Unit Dressings and Treatments, to } \\
\text { define the type of carton (standard commercial unit type) for first-aid } \\
\text { kits for merchant vessels to be used as life-saving equipment. }\end{array}$ & & DHS/USCG & 46 CFR 160.041-4 \\
\hline
\end{tabular}

\section{Appendix 8}




\begin{tabular}{|c|c|c|c|c|}
\hline $\begin{array}{l}\text { NBS Report } \\
4792\end{array}$ & $\begin{array}{l}\text { This subpart incorporates by reference "Development of a Laboratory } \\
\text { Test for Evaluation of the Effectiveness of Smoke Signals,” National } \\
\text { Bureau of Standards Report } 4792 \text {, July 1956, for specifications } \\
\text { pertaining to Floating Orange Smoke Distress Signals (15 minutes) in } \\
\text { use as lifesaving equipment. }\end{array}$ & 1956 & DHS/USCG & 46 CFR 160.057-1 \\
\hline $\begin{array}{l}\text { NBS Report } \\
4792\end{array}$ & $\begin{array}{l}\text { Reference is made to National Bureau of Standards Report No. } 4792 \text { to } \\
\text { define the apparatus to be used for determining the volume and density } \\
\text { of smoke in testing of Floating Orange Smoke Distress Signals ( } 15 \\
\text { Minutes) to be used as lifesaving equipment. }\end{array}$ & 1956 & DHS/USCG & 46 CFR 160.057-4(d)(9) \\
\hline $\begin{array}{l}\text { NBS Building } \\
\text { Materials and } \\
\text { Structures Report } \\
150\end{array}$ & $\begin{array}{l}\text { Reference is made to the NBS Building Materials and Structures Report } \\
150 \text { as a source of fire tests that may be used in addition to the usual } \\
\text { fire tests to determine adequacy of a portable fire extinguisher to be } \\
\text { listed and labeled as a "marine type" extinguisher as part of the } \\
\text { requirements for engineering equipment. }\end{array}$ & & DHS/USCG & 46 CFR 162.028-3(m) \\
\hline $\begin{array}{l}\text { NBS Technical } \\
\text { Note } 101\end{array}$ & $\begin{array}{l}\text { In defining the Procedure for Calculating PCS Signal Levels at } \\
\text { Microwave Receivers, the PCS to microwave path loss is calculated } \\
\text { using a model derived from the NBS Tech. Note 101. This is applicable } \\
\text { to cellular communication station design. }\end{array}$ & $\begin{array}{l}1967 \\
\text { (updated } \\
1982 \text { and } \\
1985) \text {. }\end{array}$ & FCC & $\begin{array}{l}47 \text { CFR } 24 \text { Appendix I } \\
\text { to Subpart E }\end{array}$ \\
\hline $\begin{array}{l}\text { NBS Technical } \\
\text { Note } 101\end{array}$ & $\begin{array}{l}\text { The propagation model used in the procedure for calculating PCS signal } \\
\text { levels at Microwave receivers is calculated using the Longley-Rice } \\
\text { Propagation Model Version 1.2.2, which in turn is derived from the } \\
\text { NBS Technical Note } 101 .\end{array}$ & 1967 & FCC & $\begin{array}{l}47 \text { CFR } 24.253 \\
\text { Appendix I } 4 .\end{array}$ \\
\hline $\begin{array}{l}\text { NBS Technical } \\
\text { Note } 101\end{array}$ & $\begin{array}{l}\text { This reference requires the prediction of Power Flux Density (PFD) } \\
\text { based on a point-to-point propagation model by P.L. Rice, A.G. } \\
\text { Longley, K.A. Norton, and A.P. Barsis, "Transmission loss predictions } \\
\text { for troposphere communication circuits", National Bureau of Standards } \\
\text { Technical Note } 101 \text {, Volumes I and II. This relates to frequency } \\
\text { assignment for the purpose of communication in the } 821 \mathrm{MHz} \text { to } 824 \\
\text { MHz and } 866 \mathrm{MHz} \text { to } 869 \mathrm{MHz} \text { frequency bands along the US-Canada } \\
\text { border. }\end{array}$ & & FCC & 47 CFR 90.619(c)(3)(i) \\
\hline
\end{tabular}


Appendix 9

\section{References to Weights and Measures Handbooks (Handbooks 44, 105-1 and 133) in the Code of Federal Regulations}

\begin{tabular}{|c|c|c|c|c|}
\hline $\begin{array}{l}\text { Document } \\
\text { Number }\end{array}$ & Title of Document & $\begin{array}{l}\text { Edition } \\
\text { Date }\end{array}$ & $\begin{array}{l}\text { Incorporated } \\
\text { By }\end{array}$ & Location in CFR \\
\hline $\begin{array}{l}\text { Handbook } \\
44\end{array}$ & $\begin{array}{l}\text { Reference is made to NBS Handbook } 44 \text { for stating the requirements } \\
\text { that weigh scales must comply with (mandatory): "Scales. All scales } \\
\text { shall comply with National Bureau of Standards Handbook } 44 \text {. (Latest } \\
\text { revision)." The accuracy and graduation marking of scales is also } \\
\text { defined (tables taken from the "currently effective } 1973 \text { revision)". }\end{array}$ & & USDA/AMS & 7 CFR 58.128(m) \\
\hline $\begin{array}{l}\text { Handbook } \\
44\end{array}$ & $\begin{array}{l}\text { Reference is made to NIST Handbook } 44 \text { for defining the design } \\
\text { requirements of moisture meters used in official grain moisture } \\
\text { determination and certification. Handbook } 44 \text { ( } 1991 \text { edition) is } \\
\text { incorporated by reference and this paragraph also identifies those } \\
\text { sections in Handbook } 44 \text { not incorporated by reference. }\end{array}$ & 1991 & USDA/GIPSA & 7 CFR 801.12 \\
\hline $\begin{array}{l}\text { Handbook } \\
44\end{array}$ & $\begin{array}{l}\text { References are made to various NIST Handbooks related to weights and } \\
\text { measures, including Handbook 44, and certain sections are incorporated } \\
\text { by reference. It is stated that "(a) The requirements set forth in this part } \\
802 \text { describe certain specifications, tolerances, and other technical } \\
\text { requirements for grain weighing equipment and related grain handling } \\
\text { systems used in performing Class X and Class Y weighing services, } \\
\text { official inspection services, and commercial services under the Act. All } \\
\text { scales used for official grain weight and inspection certification services } \\
\text { provided by FGIS shall meet applicable requirements contained in the } \\
\text { FGIS Weighing Handbook, the General Code, the Scales Code, the } \\
\text { Automatic Bulk Weighing Systems Code, and the Weights Code of the } \\
2002 \text { edition of National Institute of Standards and Technology (NIST) } \\
\text { Handbook 44, "Specifications, Tolerances, and Other Technical } \\
\text { Requirements for Weighing and Measuring Devices" (Handbook } 44 \text { ); } \\
\text { and NIST Handbook 105-1 (1990 Edition), "Specifications and } \\
\text { Tolerances for Reference Standards and Field Standard Weights and } \\
\text { Measures," (Handbook 105-1). These requirements are confirmed to be } \\
\text { met by having National Type Evaluation Program or Federal Grain } \\
\text { Inspection Service type approval. Scales used for commercial purposes } \\
\text { will be required to meet only the applicable requirements of the } 2002 \\
\text { edition of the NIST Handbook } 44 \text {. Pursuant to the provisions of } 5 \\
\text { U.S.C. 552(a), with the exception of the Handbook } 44 \text { requirements } \\
\text { listed in paragraph (b) of this section, the materials in Handbooks } 44\end{array}$ & 1990 & USDA/GIPSA & 7 CFR 802.0(a) \\
\hline
\end{tabular}




\begin{tabular}{|c|c|c|c|c|}
\hline & $\begin{array}{l}\text { and } 105-1 \text { are incorporated by reference as they exist on the date of } \\
\text { approval and a notice of any change in these materials will be published } \\
\text { in the Federal Register." }\end{array}$ & & & \\
\hline $\begin{array}{l}\text { Handbook } \\
44\end{array}$ & $\begin{array}{l}\text { Reference is made to NIST Handbook } 44 \text { to state that "All scales used } \\
\text { by stockyard owners, market agencies, dealers, packers, and live poultry } \\
\text { dealers to weigh livestock, livestock carcasses, live poultry, or feed for } \\
\text { the purposes of purchase, sale, acquisition, payment, or settlement shall } \\
\text { be installed, maintained, and operated to ensure accurate weights. Such } \\
\text { scales shall meet applicable requirements contained in the General } \\
\text { Code, Scale Code, and Weights Code of the } 1996 \text { edition of National } \\
\text { Institute of Standards and Technology (NIST) Handbook } 44, \\
\text { "Specifications, Tolerances, and Other Technical Requirements for } \\
\text { Weighing and Measuring Devices," which is hereby incorporated by } \\
\text { reference." }\end{array}$ & 1996 & USDA/GIPSA & 9 CFR 201.71(a) \\
\hline $\begin{array}{l}\text { Handbook } \\
44\end{array}$ & $\begin{array}{l}\text { Scale requirements for accurate weights, repairs, adjustments, and } \\
\text { replacement after inspection refer to NIST Handbook 44, and state that } \\
\text { "All scales used to weigh meat products sold or otherwise distributed in } \\
\text { commerce in federally inspected meat establishments shall be installed, } \\
\text { maintained and operated to insure accurate weights. Such scales shall } \\
\text { meet the applicable requirements contained in National Institute of } \\
\text { Standards and Technology Handbook 44, "Specifications, Tolerances, } \\
\text { and Other Technical Requirements for Weighing and Measuring } \\
\text { Devices", } 1999 \text { Edition, November 1998, which is incorporated by } \\
\text { reference." (MANDATORY), incorporated by reference }\end{array}$ & 1998 & USDA/FSIS & 9 CFR 317.20(a) \\
\hline
\end{tabular}




\begin{tabular}{|c|c|c|c|}
\hline $\begin{array}{l}\text { Handbook } \\
44\end{array}$ & $\begin{array}{l}\text { As part of the regulations on labeling, marking devices and containers, } \\
\text { this regulation refers to NIST Handbook } 44 \text { to ensure accuracy of the } \\
\text { weighing scales and states that "No scale shall be used at a federally } \\
\text { inspected establishment to weigh meat products unless it has been found } \\
\text { upon test and inspection, as specified in NIST Handbook } 44 \text {, to provide } \\
\text { accurate weight. If a scale is re-inspected or retested and found to be } \\
\text { inaccurate, or if any repairs, adjustments or replacements are made to a } \\
\text { scale, it shall not be used until it has been inspected and tested by a } \\
\text { USDA official, or a State or local government weights and measures } \\
\text { official, or State registered or licensed scale repair firm or person, and it } \\
\text { must meet all accuracy requirements as specified in NIST Handbook } \\
\text { 44. If a USDA inspector has put a retain tag on a scale it can only be } \\
\text { removed by a USDA inspector. As long as the tag is on the scale, it } \\
\text { shall not be used."(MANDATORY) }\end{array}$ & USDA/FSIS & 9 CFR 317.20 (c) \\
\hline $\begin{array}{l}\text { Handbook } \\
44\end{array}$ & $\begin{array}{l}\text { Reference is made to Handbook } 44 \text { in stating that "The operator of each } \\
\text { official establishment that weighs meat food products shall cause such } \\
\text { scales to be tested for accuracy, in accordance with the technical } \\
\text { requirements of NIST Handbook 44, at least once during the calendar } \\
\text { year...." (MANDATORY) }\end{array}$ & USDA/FSIS & 9CFR 317.21 (a) \\
\hline $\begin{array}{l}\text { Handbook } \\
44\end{array}$ & $\begin{array}{l}\text { Reference is made to Handbook } 44 \text { in stating that "The operator of each } \\
\text { official establishment shall display on or near each scale a valid } \\
\text { certification of the scale's accuracy from a State or local government's } \\
\text { weights and measures authority or from a State registered or licensed } \\
\text { scale repair firm or person, or shall have alternative documented } \\
\text { procedures showing that the scale has been tested for accuracy in } \\
\text { accordance with the requirements of NIST Handbook } 44 . "\end{array}$ & USDA/FSIS & 9CFR 317.21 (b) \\
\hline
\end{tabular}




\begin{tabular}{|c|c|c|c|c|}
\hline $\begin{array}{l}\text { Handbook } \\
44\end{array}$ & $\begin{array}{l}\text { Defining the scale requirements for accurate weights, repairs, } \\
\text { adjustment, and replacement after inspection, this regulation requires } \\
\text { that "All scales used to weigh poultry products sold or otherwise } \\
\text { distributed in commerce in federally inspected poultry plants shall be } \\
\text { installed, maintained, and operated to insure accurate weights. Such } \\
\text { scales shall meet the applicable requirements contained in National } \\
\text { Institute of Standards and Technology (NIST) Handbook 44, } \\
\text { "Specifications, Tolerances, and Other Technical Requirements for } \\
\text { Weighing and Measuring Devices", } 1999 \text { Edition, November 1998, } \\
\text { which is incorporated by reference...."(MANDATORY), incorporated } \\
\text { by reference }\end{array}$ & 1998 & USDA/FSIS & 9 CFR 381.121c(a) \\
\hline $\begin{array}{l}\text { Handbook } \\
44\end{array}$ & $\begin{array}{l}\text { Defining the scale requirements for accurate weights, repairs, } \\
\text { adjustment, and replacement after inspection, this regulation requires } \\
\text { that "No scale shall be used at a federally inspected establishment to } \\
\text { weigh poultry products unless it has been found upon test and } \\
\text { inspection as specified in NIST Handbook } 44 \text { to provide accurate } \\
\text { weight. If a scale is inspected or tested and found to be inaccurate, or if } \\
\text { any repairs, adjustments or replacements are made to a scale, it shall not } \\
\text { be used until it has been re-inspected and retested by a USDA official, } \\
\text { or a State or local government weights and measures official, or a State } \\
\text { registered or licensed scale repair firm or person, and it must meet all } \\
\text { accuracy requirements as specified in NIST Handbook 44". }\end{array}$ & 1998 & USDA/FSIS & 9 CFR 381.121c(c) \\
\hline $\begin{array}{l}\text { Handbook } \\
44\end{array}$ & $\begin{array}{l}\text { Reference is made to NIST Handbook } 44 \text { to state that "the operator of } \\
\text { each official establishment that weighs poultry food products shall } \\
\text { cause such scales to be tested for accuracy in accordance with the } \\
\text { technical requirements of NIST Handbook } 44 \text {, at least once during the } \\
\text { calendar year". It is further required that "The operator of each official } \\
\text { establishment shall display on or near each scale a valid certification of } \\
\text { the scale's accuracy from a State or local government's weights and } \\
\text { measures authority or from a State registered or licensed scale repair } \\
\text { firm or person, or shall have alternative documented procedures } \\
\text { showing that the scale has been tested for accuracy in accordance with } \\
\text { the requirements of NIST Handbook } 44 . " \text { (MANDATORY) }\end{array}$ & & USDA/FSIS & 9 CFR 381.121d \\
\hline
\end{tabular}

\section{Appendix 9}




\begin{tabular}{|c|c|c|c|c|}
\hline $\begin{array}{l}\text { Handbook } \\
44\end{array}$ & $\begin{array}{l}\text { Measure Container Code, section } 4.45 \text { Measure Containers; Exemptions } \\
\text { from required label statements - Mentions that certain frozen foods } \\
\text { "when measured by and packaged in } 1 / 2 \text {-liquid pint and } 1 / 2 \text {-gallon } \\
\text { measure-containers, as defined in the "Measure Container Code of } \\
\text { National Bureau of Standards Handbook } 44, " \text { Specifications, } \\
\text { Tolerances, and Other Technical Requirements for Weighing and } \\
\text { Measuring Devices, Sec. } 4.45 \text { "Measure-Containers," which is } \\
\text { incorporated by reference, are exempt from the requirements of } \S \\
101.105(b)(2) \text { of this chapter (i.e., that statements of fluid measure shall } \\
\text { be in terms of the U.S. gallon of } 231 \text { cubic inches and quart, pint, and } \\
\text { fluid ounce subdivisions thereof, and shall (i) In the case of frozen food } \\
\text { that is sold and consumed in a frozen state, express the volume at the } \\
\text { frozen temperature) to the extent that net contents of } 8 \text {-fluid ounces and } \\
\text { 64-fluid ounces (or } 2 \text { quarts) may be expressed as } 1 / 2 \text { pint and } 1 / 2 \\
\text { gallon. }\end{array}$ & NDG & HHS/FDA & $\begin{array}{l}21 \mathrm{CFR} \\
1.24(\mathrm{a})(6)(\mathrm{i})\end{array}$ \\
\hline $\begin{array}{l}\text { Handbook } \\
44\end{array}$ & $\begin{array}{l}\text { Measure Container Code, section } 4.45 \text { Measure Containers; Exemptions } \\
\text { from required label statements - mentions that the certain frozen foods } \\
\text { referred to in 21CFR1.24(a)(6)(i) when measured by and packaged in 1- } \\
\text { liquid pint, 1-liquid quart, and 1/2-gallon measure-containers, as } \\
\text { defined in the "Measure Container Code of National Bureau of } \\
\text { Standards Handbook 44," Specifications, Tolerances, and Other } \\
\text { Technical Requirements for Weighing and Measuring Devices, Sec. } \\
4.45 \text { "Measure-Containers," which is incorporated by reference, are } \\
\text { exempt from the dual net-contents declaration requirement of } \S \\
101.105(j) \text { containing labeling requirements for packages containing } \\
\text { less than } 4 \text { pounds or } 1 \text { gallon and labeled in terms of weight or fluid } \\
\text { measure. }\end{array}$ & NDG & HHS/FDA & $\begin{array}{l}21 \mathrm{CFR} \\
1.24(\mathrm{a})(6)(\mathrm{ii})\end{array}$ \\
\hline
\end{tabular}




\begin{tabular}{|c|c|c|c|c|}
\hline $\begin{array}{l}\text { Handbook } \\
44\end{array}$ & $\begin{array}{l}\text { Measure Container Code, section } 4.45 \text { Measure Containers; Exemptions } \\
\text { from required label statements. States that frozen foods referred in } 21 \\
\text { CFR1.24(a)(6)(i) when measured by and packaged in } 1 / 2 \text {-liquid pint, 1- } \\
\text { liquid pint, 1-liquid quart, } 1 / 2 \text {-gallon, and 1-gallon measured- } \\
\text { containers, as defined in the "Measure Container Code of National } \\
\text { Bureau of Standards Handbook } 44, " \text { Specifications, Tolerances, and } \\
\text { Other Technical Requirements for Weighing and Measuring Devices, } \\
\text { Sec. } 4.45 \text { "Measure-Containers," which is incorporated by reference, } \\
\text { are exempt from the requirement of } \S 101.105 \text { (f) (i.e., The declaration } \\
\text { shall appear as a distinct item on the principal display panel, shall be } \\
\text { separated (by at least a space equal to the height of the lettering used in } \\
\text { the declaration) from other printed label information appearing above or } \\
\text { below the declaration and (by at least a space equal to twice the width } \\
\text { of the letter "N" of the style of type used in the quantity of contents } \\
\text { statement) from other printed label information appearing to the left or } \\
\text { right of the declaration. It shall not include any term qualifying a unit of } \\
\text { weight, measure, or count (such as "jumbo quart" and "full gallon") that } \\
\text { tends to exaggerate the amount of the food in the container. It shall be } \\
\text { placed on the principal display panel within the bottom } 30 \text { percent of } \\
\text { the area of the label panel in lines generally parallel to the base on } \\
\text { which the package rests as it is designed to be displayed: Provided, That } \\
\text { on packages having a principal display panel of } 5 \text { square inches or less, } \\
\text { the requirement for placement within the bottom } 30 \text { percent of the area } \\
\text { of the label panel shall not apply when the declaration of net quantity of } \\
\text { contents meets the other requirements of this part.) }\end{array}$ & NDG & HHS/FDA & $\begin{array}{l}21 \text { CFR } \\
1.24(\mathrm{a})(6)(\mathrm{iii})\end{array}$ \\
\hline $\begin{array}{l}\text { Handbook } \\
44\end{array}$ & $\begin{array}{l}\text { Refers to Handbook } 44 \text { to define the requirements of the scale used to } \\
\text { measure the weight of Hazardous Air Pollutants Auxiliary Blowing } \\
\text { Agent (HAP ABA) as part of the monitoring requirements for national } \\
\text { emission standards for hazardous air pollutants for flexible polyurethane } \\
\text { foam production. }\end{array}$ & 1998 & EPA & $\begin{array}{l}40 \text { CFR } \\
63.1303(\mathrm{e})(3)\end{array}$ \\
\hline
\end{tabular}




\section{(Appendix 9 -contd.)}

\begin{tabular}{|c|c|c|c|c|}
\hline $\begin{array}{l}\text { Document } \\
\text { Number }\end{array}$ & Title of Document & $\begin{array}{l}\text { Edition } \\
\text { Date }\end{array}$ & $\begin{array}{l}\text { Incorporated } \\
\text { By }\end{array}$ & Location in CFR \\
\hline $\begin{array}{l}\text { Handbook } \\
105-1\end{array}$ & $\begin{array}{l}\text { References are made to various NIST Handbooks related to weights and } \\
\text { measures, including Handbook 105-1, and certain sections are incorporated } \\
\text { by reference. It is stated that "(a) The requirements set forth in this part } 802 \\
\text { describe certain specifications, tolerances, and other technical requirements } \\
\text { for grain weighing equipment and related grain handling systems used in } \\
\text { performing Class X and Class Y weighing services, official inspection } \\
\text { services, and commercial services under the Act. All scales used for } \\
\text { official grain weight and inspection certification services provided by FGIS } \\
\text { shall meet applicable requirements contained in the FGIS Weighing } \\
\text { Handbook, the General Code, the Scales Code, the Automatic Bulk } \\
\text { Weighing Systems Code, and the Weights Code of the } 2002 \text { edition of } \\
\text { National Institute of Standards and Technology (NIST) Handbook 44, } \\
\text { "Specifications, Tolerances, and Other Technical Requirements for } \\
\text { Weighing and Measuring Devices" (Handbook } 44 \text { ); and NIST Handbook } \\
\text { 105-1 (1990 Edition), "Specifications and Tolerances for Reference } \\
\text { Standards and Field Standard Weights and Measures," (Handbook 105-1). } \\
\text { These requirements are confirmed to be met by having National Type } \\
\text { Evaluation Program or Federal Grain Inspection Service type approval. } \\
\text { Scales used for commercial purposes will be required to meet only the } \\
\text { applicable requirements of the } 2002 \text { edition of the NIST Handbook } 44 \text {. } \\
\text { Pursuant to the provisions of } 5 \text { U.S.C. } 552 \text { (a), with the exception of the } \\
\text { Handbook } 44 \text { requirements listed in paragraph (b) of this section, the } \\
\text { materials in Handbooks } 44 \text { and } 105-1 \text { are incorporated by reference as } \\
\text { they exist on the date of approval and a notice of any change in these } \\
\text { materials will be published in the Federal Register." }\end{array}$ & 1990 & USDA/GIPSA & 7 CFR 802.0(a) \\
\hline
\end{tabular}




\begin{tabular}{|l|l|l|l||}
\hline Handbook & $\begin{array}{l}\text { Reference is made to NIST Handbook 133 for purposes of definitions, and } \\
\text { procedures to be used in determining net weight and net weight } \\
\text { compliance. Certain sections of Handbook 133 are incorporated by } \\
\text { reference, and this sub-section states the exceptions (i.e., not incorporated } \\
\text { by reference). This sub-section states, in part, "definitions, and procedures } \\
\text { to be used in determining net weight and net weight compliance are } \\
\text { described in the National Institute of Standards and Technology (NIST) } \\
\text { Handbook 133, “Checking the Net Contents of Packaged Goods," Third } \\
\text { Edition, September 1988, and Supplements 1, 2, 3, and 4 dated September } \\
\text { 1990, October 1991, October 1992, and October 1994, respectively, which } \\
\text { are incorporated by reference, with the exception of the NIST Handbook } \\
133 \text { and Supplements 1, 3, and 4 requirements listed in paragraphs (b) and } \\
\text { (c) of this section. Those provisions incorporated by reference herein, are } \\
\text { considered mandatory requirements." }\end{array}$ & USDA/FSIS & CFR 317.19(a) \\
\hline $\begin{array}{l}\text { Handbook } \\
133\end{array}$ & $\begin{array}{l}\text { Excludes certain parts of Handbook 133 that are not relevant for this } \\
\text { regulation. }\end{array}$ & & 9 CFR 317.19(b) \\
\end{tabular}

\section{Appendix 9}




\begin{tabular}{|c|c|c|c|c|}
\hline $\begin{array}{l}\text { Handbook } \\
133\end{array}$ & $\begin{array}{l}\text { Excludes certain requirements of Supplements 1,3 and } 4 \text { of Handbook } 133 \\
\text { that are not relevant to this regulation. }\end{array}$ & & & 9 CFR 317.19(c) \\
\hline \begin{tabular}{|l|} 
Handbook \\
133
\end{tabular} & $\begin{array}{l}\text { In stating the definition and procedures for determining net weigh } \\
\text { compliance in regulations pertaining to poultry product inspections, } \\
\text { reference is made to NIST Handbook } 133 \text { as, "For the purpose of } \\
\S 381.121 \text { b of this part, the reasonable variations allowed, definitions, and } \\
\text { procedures to be used in determining net weight and net weight compliance } \\
\text { are described in the National Institute of Standards and Technology (NIST) } \\
\text { Handbook 133, "Checking the Net Contents of Packaged Goods," Third } \\
\text { Edition, September 1988, and Supplements 1, 2, 3, and } 4 \text { dated September } \\
\text { 1990, October 1991, October 1992, and October 1994, respectively, which } \\
\text { are incorporated by reference, with the exception of the NIST Handbook } \\
133 \text { and Supplements } 1 \text { and } 3 \text { requirements listed in paragraphs (b) and (c) } \\
\text { of this section. Those provisions, incorporated by reference herein, are } \\
\text { considered mandatory requirements" }\end{array}$ & 1988 & USDA/FSIS & $\begin{array}{l}\text { 9 CFR } \\
381.121 \mathrm{~b}(\mathrm{a})\end{array}$ \\
\hline
\end{tabular}

\section{Appendix 9}




\begin{tabular}{|c|c|c|c|}
\hline $\begin{array}{l}\text { Handbook } \\
133\end{array}$ & $\begin{array}{l}\text { In stating the definition and procedures for determining net weigh } \\
\text { compliance in regulations pertaining to poultry product inspections, } \\
\text { specifies those requirements of NIST Handbook } 133 \text { that are not } \\
\text { incorporated by reference (In context of Handbook } 133 \text { and its supplements } \\
\text { IBR as stated in } 9 \text { CFR } 381.121 \text { b(a) }\end{array}$ & USDA/FSIS & $\begin{array}{l}\text { 9 CFR } \\
381.121 \mathrm{~b}(\mathrm{~b})\end{array}$ \\
\hline $\begin{array}{l}\text { Handbook } \\
133\end{array}$ & $\begin{array}{l}\text { In stating the definition and procedures for determining net weigh } \\
\text { compliance in regulations pertaining to poultry product inspections, } \\
\text { specifies those requirements of Supplement } 1 \text { dated September 1990, } \\
\text { Supplement } 3 \text { dated October 1992, and Supplement } 4 \text { dated October 1994, } \\
\text { of NIST Handbook } 133 \text { that are not incorporated by reference (In context of } \\
\text { Handbook } 133 \text { and its supplements IBR as stated in } 9 \text { CFR } 381.121 \text { b(a). }\end{array}$ & USDA/FSIS & $\begin{array}{l}9 \text { CFR } \\
381.121 \mathrm{~b}(\mathrm{c})\end{array}$ \\
\hline
\end{tabular}




\section{Appendix 10}

References to Accreditation, National Voluntary Laboratory Accreditation Program (NVLAP) and National Voluntary Conformity Assessment System Evaluation (NVCASE)

in the Code of Federal Regulations

\begin{tabular}{|c|c|c|c|c|}
\hline $\begin{array}{l}\text { Document } \\
\text { Number }\end{array}$ & Title of Document & $\begin{array}{l}\text { Edition } \\
\text { Date }\end{array}$ & $\begin{array}{l}\text { Incorporated } \\
\text { By }\end{array}$ & Location in CFR \\
\hline NVLAP & $\begin{array}{l}\text { Reference is made to the NVLAP program as the } \\
\text { accreditation body which accredits laboratories } \\
\text { where testing for the Energy Efficiency Program } \\
\text { can be conducted. It also recognizes laboratories } \\
\text { accredited by ABs having a MRA with NVLAP } \\
\text { for testing of Efficiency of Electrical Motors. }\end{array}$ & & $\begin{array}{l}\text { DOE/Energy } \\
\text { Efficiency }\end{array}$ & 10 CFR 431.25 \\
\hline $\begin{array}{l}\text { Fastener } \\
\text { Quality Act }\end{array}$ & $\begin{array}{l}\text { This regulation states the procedures for } \\
\text { petitioning for approval of documents related to } \\
\text { certification, accreditation, laboratory } \\
\text { accreditation and approval of accreditation bodies } \\
\text { in support of the Fastener Quality Act. }\end{array}$ & & DOC/NIST & 15 CFR 280.101 \\
\hline $\begin{array}{l}\text { Fastener } \\
\text { Quality Act }\end{array}$ & $\begin{array}{l}\text { This regulation, in support of the Fastener } \\
\text { Quality Act, requires that "An accreditation body } \\
\text { accrediting third parties who certify } \\
\text { manufacturing systems as fastener quality } \\
\text { assurance systems as described in section } \\
3(7)(B)(i i i)(I) \text { of the Act (15 U.S.C. } \\
5402(7)(B)(i i i)(I)) \text { shall affirm to the Director, } \\
\text { NIST, that it meets the requirements of ISO/IEC } \\
\text { Guide } 61 " \text { and similarly, "An accreditation body } \\
\text { accrediting laboratories as described in section } \\
3(1)(B) \text { of the Act (15 U.S.C. } 5402(1)(B)) \text { shall } \\
\text { affirm to the Director, NIST, that it meets the } \\
\text { requirements of ISO/IEC Guide 58". }\end{array}$ & & DOC/NIST & 15 CFR 280.102 \\
\hline $\begin{array}{l}\text { NVLAP } \\
\text { Accreditation }\end{array}$ & $\begin{array}{l}\text { Reference is made to the NVLAP program in } \\
\text { stating that HUD may require accreditation of } \\
\text { testing laboratories for certain products by a } \\
\text { program such as the NVLAP for HUD building } \\
\text { product certification requirements. }\end{array}$ & & HUD & 24 CFR 200.935(d)(3) \\
\hline
\end{tabular}




\begin{tabular}{|c|c|c|c|}
\hline $\begin{array}{l}\text { NVLAP } \\
\text { Accreditation }\end{array}$ & $\begin{array}{l}\text { States that periodic testing for quality control will } \\
\text { be conducted on "select samples for testing, and } \\
\text { testing shall be conducted, in accordance with the } \\
\text { applicable standards in a laboratory accredited by } \\
\text { the National Voluntary Laboratory Accreditation } \\
\text { Program (NVLAP) of the National Bureau of } \\
\text { Standards, U.S. Department of Commerce" } \\
\text { (mandatory) }\end{array}$ & HUD & 24 CFR 200.942(c)(1) \\
\hline $\begin{array}{l}\text { NVLAP } \\
\text { Accreditation }\end{array}$ & $\begin{array}{l}\text { Requires that "Every six months, three samples } \\
\text { and one annual field sample of carpet shall be } \\
\text { submitted to the Administrator for testing in a } \\
\text { laboratory accredited by the National Voluntary } \\
\text { Laboratory Accreditation Program of the U.S. } \\
\text { Department of Commerce" as part of a periodic } \\
\text { testing and quality assurance inspection protocol } \\
\text { under Supplementary specific requirements under } \\
\text { the HUD building product standards and } \\
\text { certification program for carpet (mandatory). }\end{array}$ & HUD & 24 CFR 200.945 \\
\hline NVLAP & $\begin{array}{l}\text { Asbestos -- B) Performing tests of the material } \\
\text { containing PACM which demonstrate that no } \\
\text { ACM is present in the material..... Analysis of } \\
\text { samples shall be performed by persons or } \\
\text { laboratories with proficiency demonstrated by } \\
\text { current successful participation in a nationally } \\
\text { recognized testing program such as the National } \\
\text { Voluntary Laboratory Accreditation Program } \\
\text { (NVLAP) or the National Institute for Standards } \\
\text { and Technology (NIST) or the Round Robin for } \\
\text { bulk samples administered by the American } \\
\text { Industrial Hygiene Association (AIHA) or an } \\
\text { equivalent nationally-recognized round robin } \\
\text { testing program. }\end{array}$ & DOL/OSHA & 29 CFR 1910.1001 \\
\hline
\end{tabular}




\begin{tabular}{|c|c|c|c|}
\hline $\begin{array}{l}\text { NVLAP } \\
\text { accreditation }\end{array}$ & $\begin{array}{l}\text { This regulation requires that for performing tests } \\
\text { of the material containing PACM (Presumed } \\
\text { Asbestos Containing Material) which } \\
\text { demonstrate that no ACM (asbestos containing } \\
\text { material) is present in the material "Analysis of } \\
\text { samples shall be performed by persons or } \\
\text { laboratories with proficiency demonstrated by } \\
\text { current successful participation in a nationally } \\
\text { recognized testing program such as the National } \\
\text { Voluntary Laboratory Accreditation Program } \\
\text { (NVLAP) or the National Institute for Standards } \\
\text { and Technology (NIST) or the Round Robin for } \\
\text { bulk samples administered by the American } \\
\text { Industrial Hygiene Association (AIHA) or an } \\
\text { equivalent nationally-recognized round robin } \\
\text { testing program" for testing related to asbestos } \\
\text { exposure. }\end{array}$ & DOL/OSHA & $\begin{array}{l}29 \\
\text { CFR1926.1101(j)(5)(ii)(B) }\end{array}$ \\
\hline $\begin{array}{l}\text { Proficiency } \\
\text { Testing }\end{array}$ & $\begin{array}{l}\text { Reference is made to NIST having conducted } \\
\text { proficiency testing of laboratories on a national } \\
\text { scale for method performance of the Polarized } \\
\text { Light Microscopy of Asbestos (Non-Mandatory) } \\
\text { under the safety and health regulations for } \\
\text { construction. }\end{array}$ & DOL/OSHA & $\begin{array}{l}29 \text { CFR 1926.1101 } \\
\text { Appendix K 1.4.1 }\end{array}$ \\
\hline $\begin{array}{l}\text { NBS } \\
\text { Accredited } \\
\text { Laboratories }\end{array}$ & $\begin{array}{l}\text { This regulation pertains to analysis of asbestos } \\
\text { containing materials in schools and states that } \\
\text { "Local education agencies shall have bulk } \\
\text { samples, collected under } \$ 763.86 \text { and submitted } \\
\text { for analysis, analyzed for asbestos using } \\
\text { laboratories accredited by the National Bureau of } \\
\text { Standards (NBS). Local education agencies shall } \\
\text { use laboratories which have received interim } \\
\text { accreditation for polarized light microscopy } \\
\text { (PLM) analysis under the EPA Interim Asbestos } \\
\text { Bulk Sample Analysis Quality Assurance } \\
\text { Program until the NBS PLM laboratory } \\
\text { accreditation program for PLM is operational." }\end{array}$ & EPA & 40 CFR 763.87(a) \\
\hline
\end{tabular}




\begin{tabular}{|c|c|c|c|}
\hline $\begin{array}{l}\text { NBS } \\
\text { Accredited } \\
\text { Laboratories }\end{array}$ & $\begin{array}{l}\text { This regulation pertains to response actions to } \\
\text { asbestos containing materials in schools and } \\
\text { states that "Local education agencies shall have } \\
\text { air samples collected under this section analyzed } \\
\text { for asbestos using laboratories accredited by the } \\
\text { National Bureau of Standards to conduct such } \\
\text { analysis using transmission electron microscopy } \\
\text { (TEM) or, under circumstances permitted in this } \\
\text { section, laboratories enrolled in the American } \\
\text { Industrial Hygiene Association Proficiency } \\
\text { Analytical Testing Program for phase contrast } \\
\text { microscopy (PCM)." }\end{array}$ & EPA & 40 CFR 763.90(h)(2)(ii) \\
\hline Accreditation & $\begin{array}{l}\text { This regulation refers to the NIST NVLAP and } \\
\text { states that "EPA recommends that transmission } \\
\text { electron microscopy (TEM) be used for analysis } \\
\text { of final air clearance samples, and that sample } \\
\text { analyses be performed by laboratories accredited } \\
\text { by the National Institute of Standards and } \\
\text { Technology's (NIST) National Voluntary } \\
\text { Laboratory Accreditation Program (NVLAP)" as } \\
\text { part of the air monitoring requirements in the } \\
\text { procedures to determine airborne concentrations } \\
\text { of asbestos fibers, as part of the Asbestos Model } \\
\text { Accreditation Plan for States. }\end{array}$ & EPA & $\begin{array}{l}\text { 40 CFR } 763 \text { Appendix C } \\
\text { I.B.2(h) }\end{array}$ \\
\hline $\begin{array}{l}\text { Accreditation } \\
\text { (NVCASE) }\end{array}$ & $\begin{array}{l}\text { NIST/NVCASE is referred to as the accreditation } \\
\text { body of Telecommunication Certification Bodies } \\
\text { (TCBs) designated by the FCC. TCBs can be } \\
\text { accredited under the "NVCASE program or other } \\
\text { recognized programs based on ISO/IEC Guide } \\
65 \text {, to comply with the Commission's } \\
\text { qualification criteria for TCBs". Further per this } \\
\text { paragraph "NIST may, in accordance with its } \\
\text { procedures, allow other appropriately qualified } \\
\text { accrediting bodies to accredit TCBs and testing } \\
\text { laboratories". }\end{array}$ & FCC & 47 CFR 2.960(b) \\
\hline
\end{tabular}




\begin{tabular}{|c|c|c|c|}
\hline TCBs & $\begin{array}{l}\text { The FCC requires TCBs (Telecommunication } \\
\text { Certification Bodies) to "participate in any } \\
\text { consultative activities, identified by the } \\
\text { Commission or NIST, to facilitate a common } \\
\text { understanding and interpretation of applicable } \\
\text { regulations", as part of the requirements for } \\
\text { TCBs. }\end{array}$ & $\mathrm{FCC}$ & 47 CFR 2.962(c)(5) \\
\hline $\begin{array}{l}\text { Designation of } \\
\text { TCBs }\end{array}$ & $\begin{array}{l}\text { The NIST role in the FCC designation of an } \\
\text { organization as a TCB (Telecommunication } \\
\text { Certification Bodies), or withdrawal of the } \\
\text { designation, is recognized. }\end{array}$ & FCC & 47 CFR 2.962(e) \\
\hline Accreditation & $\begin{array}{l}\text { FCC will designate as a TCB } \\
\text { (Telecommunication Certification Body) any } \\
\text { organization that meets the qualification criteria } \\
\text { and is accredited by NIST or its recognized } \\
\text { accreditor }\end{array}$ & FCC & 47 CFR 68.160 \\
\hline $\begin{array}{l}\text { Accreditation } \\
\text { (NVCASE) }\end{array}$ & $\begin{array}{l}\text { TCBs shall be accredited by the NIST under its } \\
\text { NVCASE program, or other recognized programs } \\
\text { based on ISO/IEC Guide } 65 \text {, to comply with the } \\
\text { Commission's qualification criteria for TCBs. } \\
\text { NIST may, in accordance with its procedures, } \\
\text { allow other appropriately qualified accrediting } \\
\text { bodies to accredit TCBs and testing laboratories. }\end{array}$ & FCC & 47 CFR 68.160 \\
\hline Accreditation & $\begin{array}{l}\text { The FCC requires TCBs to "participate in any } \\
\text { consultative activities, identified by the } \\
\text { Commission or NIST, to facilitate a common } \\
\text { understanding and interpretation of applicable } \\
\text { regulations" as part of the requirements for } \\
\text { TCBs. }\end{array}$ & FCC & 47 CFR $68.162(\mathrm{c})(5)$ \\
\hline $\begin{array}{l}\text { Accreditation } \\
\text { Of TCBs }\end{array}$ & $\begin{array}{l}\text { The NIST role in the FCC designation of an } \\
\text { organization as a TCB, or withdrawal of the } \\
\text { designation, is recognized. }\end{array}$ & FCC & 47 CFR 68.162 (e) \\
\hline
\end{tabular}




\section{Appendix 11 \\ References to Voluntary Product Standards (VPS) and Commercial Standards (CS) in the Code of Federal Regulations}

\begin{tabular}{|c|c|c|c|c|}
\hline $\begin{array}{l}\text { Document } \\
\text { Number }\end{array}$ & Title of Document & $\begin{array}{l}\text { Edition } \\
\text { Date }\end{array}$ & $\begin{array}{l}\text { Incorporated } \\
\text { By }\end{array}$ & $\begin{array}{l}\text { Location in } \\
\text { CFR }\end{array}$ \\
\hline $\begin{array}{l}\text { NBS } \\
\text { Voluntary } \\
\text { Product } \\
\text { Standard } \\
54-72\end{array}$ & $\begin{array}{l}\text { "Body Measurements for Sizing Girls Apparel (sizes 7-14) (formerly CS 153-48)" - } \\
\text { The CPSC uses the stated NBS voluntary product standard for defining "tight-fitting } \\
\text { garments" in their standard that provides a test method to determine flammability of } \\
\text { children's sleepwear (sizes 7-14). This Voluntary Product Standard establishes a } \\
\text { nationally recognized sizing system for girls, based on body measurements. }\end{array}$ & 1973 & CPSC & $\begin{array}{c}16 \text { CFR } \\
1616.2(\mathrm{~b})\end{array}$ \\
\hline $\begin{array}{l}\text { Voluntary } \\
\text { Product } \\
\text { Standard }\end{array}$ & $\begin{array}{l}\text { Definition of voluntary product standards- states that "If there exists a voluntary } \\
\text { product standard promulgated pursuant to the procedures found in } 15 \text { CFR part } 10 \text { by } \\
\text { the Department of Commerce, quantitatively defining the meaning of the term } \\
\text { serving with respect to a particular food, then any label representation as to the } \\
\text { number of servings in such packaged food shall correspond with such quantitative } \\
\text { definition. (Copies of published standards are available upon request from the } \\
\text { National Bureau of Standards, Department of Commerce, Washington, DC 20234.)" }\end{array}$ & & HHS/FDA & $\begin{array}{c}21 \mathrm{CFR} \\
501.8(\mathrm{~b})\end{array}$ \\
\hline PS $1-83$ & $\begin{array}{l}\text { Reference is made to NIST PS } 1-83 \text { "Product Standard for Construction and } \\
\text { Industrial Plywood with Typical APA Trademarks" as a standard that has been } \\
\text { incorporated by reference in the HUD Minimum Property Standards (MPS) in } 24 \\
\text { CFR part } 200 .\end{array}$ & 1983 & HUD & $\begin{array}{l}24 \text { CFR 200, } \\
\text { Appendix A }\end{array}$ \\
\hline PS 2-92 & $\begin{array}{l}\text { Reference is made to NIST PS 2-92 "Performance Standard for Wood-Based } \\
\text { Structural-Use Panels" as a standard that has been incorporated by reference in the } \\
\text { HUD Minimum Property Standards (MPS) in } 24 \text { CFR part } 200 .\end{array}$ & 1992 & HUD & $\begin{array}{l}24 \text { CFR 200, } \\
\text { Appendix A }\end{array}$ \\
\hline
\end{tabular}




\begin{tabular}{|c|c|c|c|c|}
\hline $\begin{array}{l}\text { Voluntary } \\
\text { Public } \\
\text { Standard } \\
1-83\end{array}$ & $\begin{array}{l}\text { Construction and Industrial Plywood - States that " All plywood made to } \\
\text { specifications of Voluntary Product Standard, PS } 1-83 \text {, "Construction and Industrial } \\
\text { Plywood" (published by the U.S. Department of Commerce, National Bureau of } \\
\text { Standards (May 1984)) and grade marked as PS } 1-83 \text { shall conform to the } \\
\text { requirements of PS 1-83, except that all veneers may be D-grade" as a } \\
\text { supplementary specific requirements under the HUD building product standards and } \\
\text { certification program for plywood and other performance rated wood-based } \\
\text { structural-use panels (mandatory). }\end{array}$ & & HUD & $\begin{array}{c}24 \text { CFR } \\
200.944\end{array}$ \\
\hline $\begin{array}{l}\text { Voluntary } \\
\text { Public } \\
\text { Standard } \\
20-94\end{array}$ & $\begin{array}{l}\text { States that lumber shall be grade marked in compliance with VPS 20-94 American } \\
\text { Softwood Lumber Standard as a Supplementary specific requirements under the } \\
\text { HUD building product standards and certification program for the grade marking of } \\
\text { lumber. This VPS has been incorporated by reference. }\end{array}$ & 1994 & HUD & $\begin{array}{l}24 \text { CFR } \\
200.943(a)(1)\end{array}$ \\
\hline $\begin{array}{l}\text { Voluntary } \\
\text { Product } \\
\text { Standard } \\
1-83\end{array}$ & $\begin{array}{l}\text { In specifying Body and Frame Construction Requirements under Manufactured } \\
\text { Home Construction and Safety Standards, this regulation refers to Voluntary Product } \\
\text { Standard, Construction and Industrial Plywood -PS-1-83 (standards for wood and } \\
\text { wood products). Materials meeting this standard when appropriate are considered } \\
\text { acceptable unless otherwise specified herein or unless substantial doubt exists as to } \\
\text { conformance. }\end{array}$ & & HUD & $\begin{array}{l}24 \text { CFR } \\
3280.304(b)(1)\end{array}$ \\
\hline $\begin{array}{l}\text { Public } \\
\text { Standard } \\
2-92\end{array}$ & $\begin{array}{l}\text { In specifying Body and Frame Construction Requirements under Manufactured } \\
\text { Home Construction and Safety Standards, this regulation refers to Performance } \\
\text { Standard for Wood-Based Structural Use Panels-PS-2-92, APA. Materials meeting } \\
\text { this standard when appropriate are considered acceptable unless otherwise specified } \\
\text { herein or unless substantial doubt exists as to conformance. }\end{array}$ & & HUD & $\begin{array}{c}24 \text { CFR } \\
3280.304\end{array}$ \\
\hline CS 138-55 & $\begin{array}{l}\text { Reference is made to NIST CS } 138-55 \text { "Insect Wire Screening" as a standard that } \\
\text { has been incorporated by reference in the HUD Minimum Property Standards } \\
\text { (MPS) in } 24 \text { CFR part } 200 .\end{array}$ & 1955 & HUD & $\begin{array}{l}24 \text { CFR 200, } \\
\text { Appendix A }\end{array}$ \\
\hline CS 242-62 & $\begin{array}{l}\text { Reference is made to NIST CS } 242-62 \text { "1 } 3 / 4 \text { " Steel Doors \& Frames" as a standard } \\
\text { that has been incorporated by reference in the HUD Minimum Property Standards } \\
\text { (MPS) in } 24 \text { CFR part } 200 .\end{array}$ & 1962 & HUD & $\begin{array}{c}24 \text { CFR 200, } \\
\text { Appendix A }\end{array}$ \\
\hline CS 202-56 & $\begin{array}{l}\text { Industrial Lifts and Hinged Loading Ramps " Powered dockboards shall be designed } \\
\text { and constructed in accordance with Commercial Standard CS202-56 (1961) } \\
\text { "Industrial Lifts and Hinged Loading Ramps published by the U.S. Department of } \\
\text { Commerce, which is incorporated by reference as specified in } § 1910.6 . "\end{array}$ & 1961 & DOL/OSHA & $\begin{array}{l}29 \text { CFR } \\
1910.30(3)\end{array}$ \\
\hline
\end{tabular}




\section{References to NIST and NBS Products on Computer Security in the Code of Federal Regulations}

\begin{tabular}{|c|c|c|c|c|}
\hline $\begin{array}{l}\text { Document } \\
\text { Number }\end{array}$ & Title of Document & $\begin{array}{l}\text { Edition } \\
\text { Date }\end{array}$ & $\begin{array}{l}\text { Incorporated } \\
\text { By }\end{array}$ & $\begin{array}{l}\text { Location in } \\
\text { CFR }\end{array}$ \\
\hline $\begin{array}{l}\text { NBS } \\
\text { Computer } \\
\text { Security } \\
\text { guidelines }\end{array}$ & $\begin{array}{l}\text { The paragraph refers to "standards" issued by the NBS on computer security and } \\
\text { states that "managers of automated personnel records shall establish administrative, } \\
\text { technical, physical, and security safeguards for data about individuals in automated } \\
\text { records, including input and output documents, reports, punched cards, magnetic } \\
\text { tapes, disks, and on-line computer storage. The safeguards must be in writing to } \\
\text { comply with the standards on automated data processing physical security issued by } \\
\text { the National Bureau of Standards, U.S. Department of Commerce" }\end{array}$ & & OPM & $\begin{array}{l}5 \text { CFR } \\
293.107(a)\end{array}$ \\
\hline $\begin{array}{l}\text { NBS } \\
\text { Computer } \\
\text { Security } \\
\text { guidelines }\end{array}$ & $\begin{array}{l}\text { This regulation refers to guidelines developed by the DoC(NBS) and other } \\
\text { government agencies to ensure safety of information in manual and computer based } \\
\text { systems. The regulation states that "whenever records in the manual or computer- } \\
\text { based record systems, including input and output documents, punched cards, and } \\
\text { magnetic tapes or disks, are not under the personal control of an authorized person, } \\
\text { they will be stored in lockable containers and/or in a secured room, or in alternative } \\
\text { storage systems which furnish an equivalent or greater degree of physical security. In } \\
\text { this regard, the Commission may refer to security guidelines prepared by the General } \\
\text { Services Administration, the Department of Commerce (National Bureau of } \\
\text { Standards), or other agencies with appropriate knowledge and expertise". }\end{array}$ & & FERC & $\begin{array}{c}18 \text { CFR } \\
3 b .204(b)\end{array}$ \\
\hline $\begin{array}{l}\text { NBS } \\
\text { Computer } \\
\text { Security } \\
\text { guidelines }\end{array}$ & $\begin{array}{l}\text { As per the Privacy Act of 1974, this regulation states that amongst other requirements } \\
\text { "when the records subject to the Act are maintained in computerized form, safeguards } \\
\text { shall be utilized based on those recommended in the National Bureau of Standard's } \\
\text { booklet "Computer Security Guidelines for Implementing the Privacy Act of 1974" } \\
\text { (May 30, 1975), and any supplements thereto, which are adequate and appropriate to } \\
\text { assuring the integrity of the records". "The Act requires that records subject to the Act } \\
\text { be maintained with appropriate administrative, technical and physical safeguards to } \\
\text { ensure the security and confidentiality of records and to protect against any } \\
\text { anticipated threats or hazards to their security or integrity which could result in } \\
\text { substantial harm, embarrassment, inconvenience or unfairness to any individual on } \\
\text { whom information is maintained". }\end{array}$ & 1975 & $\begin{array}{l}\text { Foreign } \\
\text { Relations }\end{array}$ & $\begin{array}{l}22 \text { CFR } \\
1101.5(\mathrm{c})\end{array}$ \\
\hline
\end{tabular}




\begin{tabular}{|c|c|c|c|c|}
\hline $\begin{array}{l}\text { NBS } \\
\text { Publication - } \\
\text { computer } \\
\text { security }\end{array}$ & $\begin{array}{l}\text { "(c) When maintained in computerized form, student records shall be maintained, at a } \\
\text { minimum, subject to safeguards based on those recommended in the National Bureau } \\
\text { of Standards' booklet, "Computer Security Guidelines for Implementing the Privacy } \\
\text { Act of 1974" (May 30, 1975), and any supplements to it, which are adequate and } \\
\text { appropriate to assure the integrity of records in the system." }\end{array}$ & 1974 & Indian Affairs & $\begin{array}{c}25 \text { CFR } \\
43.22(\mathrm{c})\end{array}$ \\
\hline $\begin{array}{l}\text { NBS } \\
\text { Computer } \\
\text { Security } \\
\text { guidelines }\end{array}$ & $\begin{array}{l}\text { "(c) Records maintained in computerized form. When maintained in computerized } \\
\text { form, records subject to the Privacy Act shall be maintained, at a minimum, subject to } \\
\text { safeguards based on those recommended in the National Bureau of Standards booklet } \\
\text { "Computer Security Guidelines for Implementing the Privacy Act of 1974" (May 30, } \\
\text { 1975), and any supplements thereto, which are adequate and appropriate to assuring } \\
\text { the integrity of records in the system." }\end{array}$ & 1975 & Indians & $\begin{array}{r}25 \text { CFR } \\
700.263\end{array}$ \\
\hline $\begin{array}{l}\text { NBS } \\
\text { Security } \\
\text { Guidelines }\end{array}$ & $\begin{array}{l}\text { "(a) The Office Administrator or Security Officer shall be responsible for issuing } \\
\text { regulations governing the security of systems of records. To the extent that such } \\
\text { regulations govern the security of automated systems of records, the regulations shall } \\
\text { be consistent with the guidelines developed by the National Bureau of Standards." }\end{array}$ & & $\begin{array}{l}\text { Judicial } \\
\text { Administration }\end{array}$ & 28 CFR 700.24 \\
\hline $\begin{array}{l}\text { Security } \\
\text { standards }\end{array}$ & $\begin{array}{l}\text { This regulation states that "Automated systems shall comply with the security } \\
\text { standards promulgated by the National Bureau of Standards" to meet the } \\
\text { requirements of accurate and secure maintenance of records under the Privacy Act. }\end{array}$ & & Treasury & $\begin{array}{l}31 \mathrm{CFR} \\
1.22(\mathrm{~d})(3)(\mathrm{i})\end{array}$ \\
\hline $\begin{array}{l}\text { Security } \\
\text { standards }\end{array}$ & $\begin{array}{l}\text { security and privacy requirements established by the NIST for electronic data } \\
\text { interchange-This regulation cites security and privacy requirements established by the } \\
\text { National Institute of Standards and Technology (NIST) for electronic data } \\
\text { interchange, and permit the use of electronic signatures on travel documents under the } \\
\text { Agency Travel Accountability Requirements, if the stated regulations are met. }\end{array}$ & & $\begin{array}{l}\text { Public } \\
\text { Contracts and } \\
\text { Property } \\
\text { Management }\end{array}$ & $\begin{array}{l}\text { 41 CFR 301- } \\
71.3\end{array}$ \\
\hline $\begin{array}{l}\text { NBS } \\
\text { Computer } \\
\text { Security } \\
\text { guidelines }\end{array}$ & $\begin{array}{l}\text { This regulation refers to a NBS publication on computer security guidelines and states } \\
\text { that "When maintained in computerized form, records subject to the Privacy Act shall } \\
\text { be maintained, at a minimum, subject to safeguards based on those recommended in } \\
\text { the National Bureau of Standard's booklet "Computer Security Guidelines for } \\
\text { Implementing the Privacy Act of 1974" (May } 30,1975 \text { ), and any supplements thereto, } \\
\text { which are adequate and appropriate to assuring the integrity of records in the system." }\end{array}$ & 1975 & Interior & 43 CFR 2.51(c) \\
\hline $\begin{array}{l}\text { NBS FIPS } \\
\text { publication }\end{array}$ & $\begin{array}{l}\text { Reference is made to the NBS FIPS publication as the source of information } \\
\text { regarding a state's identifying code when collecting and monitoring support payments } \\
\text { from non-custodial parents. }\end{array}$ & & HHS & $\begin{array}{l}45 \text { CFR } \\
303.7(\mathrm{c})(7)(\mathrm{iv})\end{array}$ \\
\hline
\end{tabular}




\begin{tabular}{|c|c|c|c|}
\hline $\begin{array}{l}\text { NBS FIPS } \\
\text { publication }\end{array}$ & $\begin{array}{l}\text { Reference is made to the NBS FIPS publication as the source of state's identifying } \\
\text { code for purposes of notification to the OCSE of liability for past-due support. }\end{array}$ & HHS & $\begin{array}{l}45 \text { CFR } \\
303.72(b)(2)(i v)\end{array}$ \\
\hline $\begin{array}{l}\text { NBS FIPS } \\
\text { Pub. } 1-1\end{array}$ & $\begin{array}{l}\text { Reference is made to the NBS FIPS Publication 1-1 which specifies the information } \\
\text { interchange requirements of the ASCII. These information interchange requirements } \\
\text { have to be met by support systems used in conjunction with automatic on-board } \\
\text { recorders used to record a driver's hours of service, to be capable of providing federal, } \\
\text { state or local officials summaries of an individual driver's hours of service records. }\end{array}$ & DOT/FMCSA & $\begin{array}{l}49 \text { CFR } \\
395.15(b)(3)\end{array}$ \\
\hline
\end{tabular}




\section{Appendix 13}

\section{References to Circular 484 in the Code of Federal Regulations}

\begin{tabular}{|c|c|c|c|c|}
\hline $\begin{array}{l}\text { Document } \\
\text { Number }\end{array}$ & Title of Document & $\begin{array}{l}\text { Edition } \\
\text { Date }\end{array}$ & $\begin{array}{l}\text { Incorporated } \\
\text { By }\end{array}$ & Location in CFR \\
\hline $\begin{array}{l}\text { Circular } \\
484\end{array}$ & $\begin{array}{l}\text { Spectrophotometry - Refers to NBS Circular } 484 \text { (incorporated by reference), } \\
\text { for establishing the absorbance accuracy (performance requirement) of a } \\
\text { spectophotometer used for determination of ultraviolet absorbance of petroleum } \\
\text { naptha. The regulation specifies the ultraviolet absorbance limits of petroleum } \\
\text { naptha that can be used in or on foods. }\end{array}$ & 1949 & HHS/FDA & $\begin{array}{l}21 \mathrm{CFR} \\
172.250(\mathrm{~b})(3)\end{array}$ \\
\hline $\begin{array}{l}\text { Circular } \\
484\end{array}$ & $\begin{array}{l}\text { Spectrophotometry - Refers to NBS Circular } 484 \text { (incorporated by reference), } \\
\text { for establishing the absorbance accuracy (performance requirement) of a } \\
\text { spectophotometer used for determination of ultraviolet absorbance of synthetic } \\
\text { fatty alcohols. The regulation specifies the ultraviolet absorbance limits of } \\
\text { synthetic fatty alcohols (for safe use) that can be used in or on foods. }\end{array}$ & & HHS/FDA & 21 CFR 172.864 \\
\hline $\begin{array}{l}\text { Circular } \\
484\end{array}$ & $\begin{array}{l}\text { Spectrophotometry - Refers to NBS Circular } 484 \text { (incorporated by reference), } \\
\text { for establishing the absorbance accuracy (performance requirement) of a } \\
\text { spectophotometer used for determination of ultraviolet absorbance of petroleum } \\
\text { wax. The regulation specifies the ultraviolet absorbance limits of petroleum wax } \\
\text { (for safe use) that can be used in or on foods. }\end{array}$ & 1949 & HHS/FDA & 21 CFR 172.886 \\
\hline $\begin{array}{l}\text { Circular } \\
484\end{array}$ & $\begin{array}{l}\text { Refers to NBS Circular } 484 \text { (incorporated by reference), for establishing the } \\
\text { absorbance accuracy (performance requirement) of a spectophotometer using } \\
\text { potassium chromate for reference standard; used for determination of ultraviolet } \\
\text { absorbance of mineral oil. The regulation specifies the ultraviolet absorbance } \\
\text { limits of mineral oil that can be safely used as a component of nonfood articles } \\
\text { intended for use in contact with food. }\end{array}$ & & HHS/FDA & $\begin{array}{l}21 \mathrm{CFR} \\
178.3620(\mathrm{c})(3)(\mathrm{iii})\end{array}$ \\
\hline $\begin{array}{l}\text { Circular } \\
484\end{array}$ & $\begin{array}{l}\text { Refers to "National Bureau of Standards Circular 484, Spectrophotometry, U.S. } \\
\text { Department of Commerce, } 1949 \text { " for establishing procedure used to determine } \\
\text { accuracy of absorbance limits in the analytical method for determining ultraviolet } \\
\text { absorbance limits and pyrene content of mineral oil that can be safely used as a } \\
\text { component of nonfood articles intended for use in contact with food. }\end{array}$ & 1949 & HHS/FDA & $\begin{array}{l}21 \mathrm{CFR} \\
178.3620(\mathrm{~d})(3)(\mathrm{I})(\mathrm{F})\end{array}$ \\
\hline
\end{tabular}




\begin{tabular}{|l|l|l|l||}
$\begin{array}{l}\text { Circular } \\
484\end{array}$ & $\begin{array}{l}\text { Spectrophotometry - Refers to a procedure described NBS Circular } 484 \\
\text { (incorporated by reference) for determination of UV absorbance accuracy of } \\
\text { spectrophotometer while establishing accuracy limits in measurement of } \\
\text { polyhydric alcohol esters of oxidatively refined (Gersthofen process) montan wax } \\
\text { in order to be safely used as components of articles intended for use in contact } \\
\text { with food. }\end{array}$ & 1949 & HHS/FDA \\
\hline $\begin{array}{l}\text { Circular } \\
484\end{array}$ & $\begin{array}{l}\text { Spectrophotometry -refers to NBS circular 484 (incorporated by reference) for } \\
\text { establishing the absorbance accuracy (performance requirement) of a } \\
\text { spectophotometer used for determination of ultraviolet absorbance of lubricants. } \\
\text { The regulation specifies the ultraviolet absorbance limits for safe use of lubricants } \\
\text { used in the manufacture of metallic articles that contact foods. }\end{array}$ & 1949 & HHS/FDA \\
\hline
\end{tabular}




\section{Appendix 14 \\ References to Handbook 69 in the Code of Federal Regulations}

\begin{tabular}{|c|c|c|c|c|}
\hline $\begin{array}{l}\text { Document } \\
\text { Number }\end{array}$ & Title of Document & $\begin{array}{l}\text { Edition } \\
\text { Date }\end{array}$ & $\begin{array}{l}\text { Incorporated } \\
\text { By }\end{array}$ & $\begin{array}{l}\text { Location in } \\
\text { CFR }\end{array}$ \\
\hline $\begin{array}{l}\text { NBS } \\
\text { Handbook } \\
69\end{array}$ & $\begin{array}{l}\text { Radiation exposure, " Determination of exclusion area, low population } \\
\text { zone, and population center distance."- Refers to the NBS Handbook } 69 \\
\text { (1959) in reference to determination of radiation exposure for determination } \\
\text { of exclusion area, low population zone and population center distance as } \\
\text { part of Reactor Site criteria. }\end{array}$ & 1959 & DOE/NRC & 10 CFR 100.11 \\
\hline $\begin{array}{l}\text { NBS } \\
\text { Handbook } \\
69\end{array}$ & $\begin{array}{l}\text { Reference is made to NBS Handbook } 69 \text { dated June } 5,1959 \text {, in the context } \\
\text { of determination of radiation exposure status. The citation reads "A whole } \\
\text { body dose of } 25 \text { rem has been stated to correspond numerically to the once } \\
\text { in a lifetime accidental or emergency dose for radiation workers which, } \\
\text { according to NCRP recommendations at the time could be disregarded in } \\
\text { the determination of their radiation exposure status (see NBS Handbook } 69 \\
\text { dated June 5, 1959). However, its use is not intended to imply that this } \\
\text { number constitutes an acceptable limit for an emergency dose to the public } \\
\text { under accident conditions. Rather, this dose value has been set forth in this } \\
\text { section as a reference value, which can be used in the evaluation of plant } \\
\text { design features with respect to postulated reactor accidents, in order to } \\
\text { assure that such designs provide assurance of low risk of public exposure to } \\
\text { radiation, in the event of such accidents" }\end{array}$ & 1959 & $\mathrm{DOE} / \mathrm{NRC}$ & $\begin{array}{c}10 \mathrm{CFR} \\
50.34(\mathrm{a})(7)\end{array}$ \\
\hline $\begin{array}{l}\text { Handbook } \\
69\end{array}$ & $\begin{array}{l}\text { Reference is made to "National Bureau of Standards Handbook No. } 69 \\
\text { entitled "Maximum Permissible Body Burdens and Maximum Permissible } \\
\text { Concentrations of Radionuclides in Air and in Water for Occupational } \\
\text { Exposure," issued June 5, 1959" to define the conditions which occupations } \\
\text { involving exposure to radioactive substances and to ionizing radiations are } \\
\text { considered particularly hazardous and detrimental to health for minors } \\
\text { between } 16 \text { and } 18 \text { years of age, as part of the child labor regulations, orders } \\
\text { and statements of interpretation. }\end{array}$ & 1959 & DOL/WHD & $\begin{array}{l}29 \text { CFR } \\
570.57(a)(1)\end{array}$ \\
\hline
\end{tabular}




\begin{tabular}{|c|c|c|c|c|}
\hline $\begin{array}{l}\text { NBS } \\
\text { Handbook } \\
69\end{array}$ & $\begin{array}{l}\text { Reference to NBS Handbook } 69 \text {, in defining "Man-made beta particle and } \\
\text { photon emitters" as all radionuclides emitting beta particles and/or photons } \\
\text { listed in Maximum Permissible Body Burdens and Maximum Permissible } \\
\text { Concentration of Radionuclides in Air or Water for Occupational Exposure, } \\
\text { NBS Handbook } 69 \text {, except the daughter products of thorium-232, uranium- } \\
235 \text { and uranium-238, as part of the definitions under the National Primary } \\
\text { Drinking Water Regulations. }\end{array}$ & 1963 & EPA & 40 CFR 141.2 \\
\hline $\begin{array}{l}\text { NBS } \\
\text { Handbook } \\
69\end{array}$ & $\begin{array}{l}\text { Reference is made to the NBS Handbook } 69 \text { to state that "Except for the } \\
\text { radionuclides listed in table A, the concentration of man-made } \\
\text { radionuclides causing } 4 \text { mrem total body or organ dose equivalents must be } \\
\text { calculated on the basis of } 2 \text { liter per day drinking water intake using the } 168 \\
\text { hour data list in "Maximum Permissible Body Burdens and Maximum } \\
\text { Permissible Concentrations of Radionuclides in Air and in Water for } \\
\text { Occupational Exposure," NBS (National Bureau of Standards) Handbook } \\
69 \text { as amended August 1963, U.S. Department of Commerce" } \\
\text { (MANDATORY) incorporated by reference }\end{array}$ & 1963 & EPA & $\begin{array}{l}40 \text { CFR } \\
141.66(d)(2)\end{array}$ \\
\hline $\begin{array}{l}\text { Handbook } \\
69\end{array}$ & $\begin{array}{l}\text { This regulation states that "All new activities and modification of existing } \\
\text { facilities which involve the continuous release of radioactive materials in } \\
\text { effluents to air, water or sanitary sewerage systems will not exceed } 1 \\
\text { percent of the activity concentration as specified in National Council on } \\
\text { Radiation Protection and Measurement Report No. } 22 \text { (National Bureau of } \\
\text { Standards Handbook No. 69) and } 10 \text { CFR part } 20 \text { when averaged over } 1 \\
\text { month..." as part of policies and procedures applicable to radioactive } \\
\text { materials and nuclear accidents and incidents. }\end{array}$ & & DOD & $\begin{array}{l}32 \text { CFR } \\
650.139(\mathrm{~h})(\mathrm{i})\end{array}$ \\
\hline
\end{tabular}


Appendix 15

References to Handbook 28 in the Code of Federal Regulations

\begin{tabular}{|c|c|c|c|c|}
\hline $\begin{array}{l}\text { Document } \\
\text { Number }\end{array}$ & \begin{tabular}{|l} 
Title of Document \\
\end{tabular} & $\begin{array}{l}\text { Edition } \\
\text { Date }\end{array}$ & $\begin{array}{l}\text { Incorporated } \\
\text { By }\end{array}$ & $\begin{array}{l}\text { Location in } \\
\text { CFR }\end{array}$ \\
\hline $\begin{array}{l}\text { Handbook } \\
28\end{array}$ & $\begin{array}{l}\text { Refers to NBS Publication Handbook H28 "Screw Thread Standards for Federal } \\
\text { Service"- } 1512 \text { to specify mechanical requirements for attachment hardware under } \\
\text { requirements for bicycles. The regulation states "All threaded hardware shall be of } \\
\text { sufficient quality to allow adjustments and maintenance. Recommended quality } \\
\text { thread form is specified in Handbook H28..." }\end{array}$ & & CPSC & $\begin{array}{c}16 \text { CFR } \\
1512.4(\mathrm{~d})\end{array}$ \\
\hline $\begin{array}{l}\text { Handbook } \\
\text { H-28 }\end{array}$ & $\begin{array}{l}\text { NBS Handbook H-28 "Handbook of Screw-Thread Standards for Federal } \\
\text { Services(1957), 1957, December } 1966 \text { Edition is incorporated by reference for this } \\
\text { subpart, with references in Title } 49 \text { sections } 179.2 ; 178.45 ; 178.46 . \text { "National } \\
\text { Institute of Standards and Technology, Department of Commerce, 5285 Port Royal } \\
\text { Road, Springfield, VA 22151, USDC". }\end{array}$ & 1957 & DOT/RSPA & 49 CFR 171.7 \\
\hline $\begin{array}{l}\text { Handbook } \\
\text { H-28 }\end{array}$ & $\begin{array}{l}\text { Specification for 3T seamless steel cylinders requires all opening to be threaded. The } \\
\text { threads (taper and straight) have to be in compliance with the requirements of NBS } \\
\text { Handbook H-28 (mandatory) incorporated by reference. }\end{array}$ & 1957 & DOT/RSPA & $\begin{array}{l}49 \text { CFR } \\
178.45(\mathrm{f})(5) \mathrm{ii}-\mathrm{iv}\end{array}$ \\
\hline $\begin{array}{l}\text { Handbook } \\
\text { H-28 }\end{array}$ & $\begin{array}{l}\text { Specifications for 3AL seamless aluminum cylinders require that all openings must } \\
\text { be threaded and the threads (tapered or straight) must conform to the requirements of } \\
\text { NBS Handbook H-28 (mandatory) incorporated by reference. }\end{array}$ & 1957 & DOT/RSPA & $\begin{array}{l}49 \text { CFR } \\
178.46(\mathrm{e})(5) \text { ii-iv }\end{array}$ \\
\hline $\begin{array}{l}\text { Handbook } \\
\text { H-28 }\end{array}$ & $\begin{array}{l}\text { NBS Handbook H-28 is referred to for defining the abbreviation "NPT" to "mean an } \\
\text { American Standard Taper Pipe Thread conforming to the requirements of NBS } \\
\text { Handbook H-28" for specifications for tank cars (incorporated by reference). }\end{array}$ & 1957 & DOT/RSPA & $\begin{array}{l}49 \text { CFR } \\
179.2(\mathrm{a})(8)\end{array}$ \\
\hline
\end{tabular}




\section{Appendix 16 \\ References to Handbook 81 in the Code of Federal Regulations}

\begin{tabular}{|c|c|c|c|c|}
\hline $\begin{array}{l}\text { Document } \\
\text { Number }\end{array}$ & Title of Document & $\begin{array}{l}\text { Edition } \\
\text { Date }\end{array}$ & $\begin{array}{l}\text { Incorporated } \\
\text { By }\end{array}$ & Location in CFR \\
\hline $\begin{array}{l}\text { NBS } \\
\text { Handbook } \\
81\end{array}$ & $\begin{array}{l}\text { This regulation states that "Guy wires of poles supporting high-voltage } \\
\text { transmission lines shall meet the requirements for grounding or insulator } \\
\text { protection of the National Electrical Safety Code, part 2, entitled "Safety } \\
\text { Rules for the Installation and Maintenance of Electric Supply and } \\
\text { Communication Lines" (also referred to as National Bureau of Standards } \\
\text { Handbook } 81 \text {, November 1, 1961) and Supplement } 2 \text { thereof issued March } \\
\text { 1968, which are hereby incorporated by reference and made a part } \\
\text { hereof" as part of the safety and health standards for surface metal and } \\
\text { non-metal mines. }\end{array}$ & 1961 & DOL/MSHA & 30 CFR 56.12047 \\
\hline $\begin{array}{l}\text { NBS } \\
\text { Handbook } \\
81\end{array}$ & $\begin{array}{l}\text { This regulation states that "Guy wires of poles supporting high-voltage } \\
\text { transmission lines shall meet the requirements for grounding or insulator } \\
\text { protection of the National Electrical Safety Code, part 2, entitled "Safety } \\
\text { Rules for the Installation and Maintenance of Electric Supply and } \\
\text { Communication Lines" (also referred to as National Bureau of Standards } \\
\text { Handbook } 81 \text {, Nov. 1, 1961), and Supplement } 2 \text { thereof issued March } \\
\text { 1968, which are hereby incorporated by reference and made a part } \\
\text { hereof" as part of the safety and health standards for underground metal } \\
\text { and non-metal mines. }\end{array}$ & 1961 & DOL/MSHA & 30 CFR 57.12047 \\
\hline $\begin{array}{l}\text { National } \\
\text { Electrical } \\
\text { Safety } \\
\text { Code } \\
\text { (NBS } \\
\text { Handbook } \\
81 ? \text { ) }\end{array}$ & $\begin{array}{l}\text { Reference is made to the National Electrical Safety Code as "High-voltage } \\
\text { powerlines located above driveways, haulageways, and railroad tracks } \\
\text { shall be installed to provide the minimum vertical clearance specified in } \\
\text { National Electrical Safety Code, provided, however, "that in no event shall } \\
\text { any high-voltage powerline be installed less than } 15 \text { feet above ground". } \\
\text { The National Electrical Safety Code is the NBS Handbook } 81 \text {. }\end{array}$ & 1971 & DOL/MSHA & 30 CFR 77.807-1 \\
\hline
\end{tabular}




\section{Appendix 17 \\ References to the National Technology Transfer and Advancement Act in the Code of Federal Regulations}

\begin{tabular}{|c|c|c|c|c|}
\hline $\begin{array}{l}\text { Document } \\
\text { Number }\end{array}$ & Title of Document & $\begin{array}{l}\text { Edition } \\
\text { Date }\end{array}$ & $\begin{array}{l}\text { Incorporated } \\
\text { By }\end{array}$ & $\begin{array}{l}\text { Location in } \\
\text { CFR }\end{array}$ \\
\hline NTTAA & $\begin{array}{l}\text { This regulation states the responsibilities of the National Institute of } \\
\text { Standards and Technology pertaining to the ICSP to coordinate Federal, } \\
\text { state and local conformity assessment activities with private sector } \\
\text { conformity assessment activities (Guidance on Federal Conformity } \\
\text { Assessment, under Authority of Section 12, PL 104-113). }\end{array}$ & & DOC/NIST & 15 CFR 287.3 \\
\hline NTTAA & $\begin{array}{l}\text { This regulation states the responsibilities of Federal agencies pertaining to } \\
\text { their role under the ICSP in working with NIST and private sector bodies. } \\
\text { (Guidance on Federal Conformity Assessment, under Authority of Section } \\
\text { 12, PL 104-113). }\end{array}$ & & DOC/NIST & 15 CFR 287.4 \\
\hline NTTAA & $\begin{array}{l}\text { Defines the responsibilities of Agency Standards Executive vis-à-vis } \\
\text { working with NIST under the ICSP pertaining to the ICSP to coordinate } \\
\text { Federal, state and local conformity assessment activities with private } \\
\text { sector conformity assessment activities (Guidance on Federal Conformity } \\
\text { Assessment, under Authority of Section 12, PL 104-113). }\end{array}$ & & DOC/NIST & 15 CFR 287.5 \\
\hline
\end{tabular}


Appendix 18

References to Handbook 91 in the Code of Federal Regulations

\begin{tabular}{|l|l|l|l|c|}
\hline $\begin{array}{l}\text { Document } \\
\text { Number }\end{array}$ & Title of Document & $\begin{array}{l}\text { Edition } \\
\text { Date }\end{array}$ & $\begin{array}{l}\text { Incorporated } \\
\text { By }\end{array}$ & $\begin{array}{l}\text { Location } \\
\text { in CFR }\end{array}$ \\
\hline $\begin{array}{l}\text { NBS } \\
\text { Handbook 91 }\end{array}$ & $\begin{array}{l}\text { This subpart incorporates by reference "Experimental } \\
\text { Statistics", National Bureau of Standards Handbook No. 91 } \\
\text { (October 1966) for specifications pertaining to pollution } \\
\text { prevention equipment. }\end{array}$ & 1966 & DHS/USCG & $\begin{array}{c}46 \text { CFR } \\
162.050-4\end{array}$ \\
\hline $\begin{array}{l}\text { NBS } \\
\text { Handbook 91 }\end{array}$ & $\begin{array}{l}\text { Reference is made to NBS Handbook 91 to define the } \\
\text { procedure to be used in measurements of oil content of } \\
\text { samples (containing oil in samples) supplied by the USCG, } \\
\text { for testing pertaining to pollution prevention equipment. }\end{array}$ & & DHS/USCG & 46 CFR \\
$162.050-$ \\
$15(f)(3)$
\end{tabular}


Appendix 19

References to Handbook 96 in the Code of Federal Regulations

\begin{tabular}{|c|c|c|c|c|}
\hline $\begin{array}{l}\text { Document } \\
\text { Number }\end{array}$ & Title of Document & $\begin{array}{l}\text { Edition } \\
\text { Date }\end{array}$ & $\begin{array}{l}\text { Incorporated } \\
\text { By }\end{array}$ & $\begin{array}{l}\text { Location in } \\
\text { CFR }\end{array}$ \\
\hline $\begin{array}{l}\text { Handbook } \\
96\end{array}$ & $\begin{array}{l}\text { Refers to handbook } 96 \text { "Inspection of Processed Photographic Record Films for Aging } \\
\text { Blemishes" to define the procedures to be used for regular inspection of aging of } \\
\text { photographic film and processed photographic film as part of a records retention } \\
\text { schedule. }\end{array}$ & & DOT/MA & $\begin{array}{l}\text { 46 CFR } \\
380.21\end{array}$ \\
\hline $\begin{array}{l}\text { Presumably } \\
\text { Handbook } \\
96\end{array}$ & $\begin{array}{l}\text { Reference states that "Film used for photographing copies shall be of permanent record- } \\
\text { type meeting in all respects the minimum specifications of the National Bureau of } \\
\text { Standards, and all processes recommended by the manufacturer shall be observed to } \\
\text { protect it from deterioration or accidental destruction", as part of the general } \\
\text { requirements for copies and records - presumably a reference to NBS Handbook 96, } \\
\text { "Inspection of Processed Photographic Record Films for Aging Blemishes". }\end{array}$ & & DOT/FMCSA & $\begin{array}{l}49 \text { CFR } \\
390.31(b)(4)\end{array}$ \\
\hline
\end{tabular}


Appendix 20

References to Handbook 150 in the Code of Federal Regulations

\begin{tabular}{|c|c|c|c|c|}
\hline $\begin{array}{l}\text { Document } \\
\text { Number }\end{array}$ & Title of Document & $\begin{array}{l}\text { Edition } \\
\text { Date }\end{array}$ & $\begin{array}{l}\text { Incorporated } \\
\text { By }\end{array}$ & $\begin{array}{l}\text { Location in } \\
\text { CFR }\end{array}$ \\
\hline Handbook 150-01 & $\begin{array}{l}\text { Reference is made to the "NVLAP Handbook 150-01, "Energy Efficient } \\
\text { Lighting Products, Lamps and Luminaires, August 1993" }\end{array}$ & 1993 & DOE & $\begin{array}{l}10 \text { CFR } \\
430.22(\mathrm{c})(2)\end{array}$ \\
\hline $\begin{array}{l}\text { Handbooks 150, } \\
150-10\end{array}$ & $\begin{array}{l}\text { Reference is made to NIST Handbook } 150 \text { "National Voluntary } \\
\text { Laboratory Accreditation Program Procedures and General } \\
\text { Requirements," and Handbook 150-10 (supplement to Handbook 150, } \\
08 / 1995 \text { ) in referring to the technical requirements of the National } \\
\text { Voluntary Laboratory Accreditation Program for the Efficiency of Electric } \\
\text { Motors field of accreditation (Supplement 150-10), and all general } \\
\text { NIST/NVLAP procedures, criteria, and policies (Handbook 150). }\end{array}$ & 1995 & $\begin{array}{l}\text { DOE/Energy } \\
\text { Efficiency }\end{array}$ & 10 CFR 431.25 \\
\hline
\end{tabular}


Appendix 21

References to Handbook 136 in the Code of Federal Regulations

\begin{tabular}{|c|c|c|c|c|}
\hline $\begin{array}{l}\text { Document } \\
\text { Number }\end{array}$ & Title of Document & $\begin{array}{l}\text { Edition } \\
\text { Date }\end{array}$ & $\begin{array}{l}\text { Incorporated } \\
\text { By }\end{array}$ & $\begin{array}{l}\text { Location in } \\
\text { CFR }\end{array}$ \\
\hline Handbook 136 & $\begin{array}{l}\text { In defining the minimum criteria for equipment used in industrial } \\
\text { radiographic operations, this regulation refers to NBS Handbook 136, and } \\
\text { states that "Each radiographic exposure device, source assembly or sealed } \\
\text { source, and all associated equipment must meet the requirements specified } \\
\text { in American National Standards Institute, N432-1980 "Radiological } \\
\text { Safety for the Design and Construction of Apparatus for Gamma } \\
\text { Radiography," (published as NBS Handbook 136, issued January 1981). } \\
\text { This publication has been approved for incorporation by reference....." } \\
\text { (MANDATORY), Incorporated by Reference }\end{array}$ & 1981 & DOE/NRC & $\begin{array}{c}10 \text { CFR } \\
34.20(\mathrm{a})(1)\end{array}$ \\
\hline
\end{tabular}




\section{Appendix 22}

\section{Compiled list of NIST and NBS products and services in the Code of Federal Regulations}

\begin{tabular}{|c|c|c|c|c|}
\hline Document Number & Title of Document & $\begin{array}{l}\text { Edition } \\
\text { Date }\end{array}$ & $\begin{array}{l}\text { Incorporated } \\
\text { By }\end{array}$ & Location in CFR \\
\hline Computer Security guidelines & $\begin{array}{l}\text { The paragraph refers to "standards" issued by the NBS on computer security and } \\
\text { states that "managers of automated personnel records shall establish } \\
\text { administrative, technical, physical, and security safeguards for data about } \\
\text { individuals in automated records, including input and output documents, reports, } \\
\text { punched cards, magnetic tapes, disks, and on-line computer storage. The } \\
\text { safeguards must be in writing to comply with the standards on automated data } \\
\text { processing physical security issued by the National Bureau of Standards, U.S. } \\
\text { Department of Commerce" }\end{array}$ & & OPM & 5 CFR 293.107(a) \\
\hline SP 500-172 & $\begin{array}{l}\text { Reference is made to NIST SP 500-172 "Computer Security Training } \\
\text { Guidelines" as a source of information for providing training for employees } \\
\text { responsible for the management or use of computer systems that process } \\
\text { sensitive information. }\end{array}$ & & OPM & 5 CFR 930.302 \\
\hline Handbook 44 & $\begin{array}{l}\text { Reference is made to NBS Handbook } 44 \text { for stating the requirements that weigh } \\
\text { scales must comply with (mandatory): "Scales. All scales shall comply with } \\
\text { National Bureau of Standards Handbook } 44 \text {. (Latest revision)." The accuracy } \\
\text { and graduation marking of scales is also defined (tables taken from the } \\
\text { "currently effective } 1973 \text { revision)". }\end{array}$ & & USDA & 7 CFR 58.128(m) \\
\hline Handbook 44 & $\begin{array}{l}\text { Reference is made to NIST Handbook } 44 \text { for defining the design requirements of } \\
\text { moisture meters used in official grain moisture determination and certification. } \\
\text { Handbook } 44 \text { ( } 1991 \text { edition) is incorporated by reference and this paragraph } \\
\text { also identifies those sections in Handbook } 44 \text { not incorporated by reference. }\end{array}$ & 1991 & USDA/GIPSA & 7 CFR 801.12 \\
\hline Traceability / calibration & $\begin{array}{l}\text { References are made to the NBS program for the Certification of Capability of } \\
\text { State Measurement Laboratories for describing the criteria by which state, } \\
\text { county and city labs could be automatically approved by the Grain Inspection, } \\
\text { Packers and Stockyard Administration as qualified metrology labs and Type } \\
\text { Evaluation Labs }\end{array}$ & & USDA/GIPSA & 7 CFR 802.1 \\
\hline
\end{tabular}




\begin{tabular}{|l|l|l|l|} 
Handbook 105-1 & $\begin{array}{l}\text { References are made to various NIST Handbooks related to weights and } \\
\text { measures, including Handbook 105-1, and certain sections are incorporated by } \\
\text { reference. It is stated that "(a) The requirements set forth in this part 802 } \\
\text { describe certain specifications, tolerances, and other technical requirements for } \\
\text { grain weighing equipment and related grain handling systems used in } \\
\text { performing Class X and Class Y weighing services, official inspection services, } \\
\text { and commercial services under the Act. All scales used for official grain weight } \\
\text { and inspection certification services provided by FGIS shall meet applicable } \\
\text { requirements contained in the FGIS Weighing Handbook, the General Code, the } \\
\text { Scales Code, the Automatic Bulk Weighing Systems Code, and the Weights } \\
\text { Code of the 2002 edition of National Institute of Standards and Technology } \\
\text { (NIST) Handbook 44, "Specifications, Tolerances, and Other Technical } \\
\text { Requirements for Weighing and Measuring Devices" (Handbook 44); and NIST } \\
\text { Handbook 105-1 (1990 Edition), "Specifications and Tolerances for Reference } \\
\text { Standards and Field Standard Weights and Measures," (Handbook 105-1). } \\
\text { These requirements are confirmed to be met by having National Type } \\
\text { Evaluation Program or Federal Grain Inspection Service type approval. Scales } \\
\text { used for commercial purposes will be required to meet only the applicable } \\
\text { requirements of the 2002 edition of the NIST Handbook 44. Pursuant to the } \\
\text { provisions of 5 U.S.C. 552(a), with the exception of the Handbook 44 } \\
\text { requirements listed in paragraph (b) of this section, the materials in Handbooks } \\
\text { 44and 105-1 are incorporated by reference as they exist on the date of } \\
\text { approval and a notice of any change in these materials will be published in the } \\
\text { Federal Register." }\end{array}$ & \\
& & \\
\end{tabular}




\begin{tabular}{|c|c|c|c|c|}
\hline Handbook 44 & $\begin{array}{l}\text { References are made to various NIST Handbooks related to weights and } \\
\text { measures, including Handbook } 44 \text {, and certain sections are incorporated by } \\
\text { reference. It is stated that "(a) The requirements set forth in this part } 802 \\
\text { describe certain specifications, tolerances, and other technical requirements for } \\
\text { grain weighing equipment and related grain handling systems used in } \\
\text { performing Class X and Class Y weighing services, official inspection services, } \\
\text { and commercial services under the Act. All scales used for official grain weight } \\
\text { and inspection certification services provided by FGIS shall meet applicable } \\
\text { requirements contained in the FGIS Weighing Handbook, the General Code, the } \\
\text { Scales Code, the Automatic Bulk Weighing Systems Code, and the Weights } \\
\text { Code of the } 2002 \text { edition of National Institute of Standards and Technology } \\
\text { (NIST) Handbook } 44 \text {, "Specifications, Tolerances, and Other Technical } \\
\text { Requirements for Weighing and Measuring Devices" (Handbook } 44 \text { ); and NIST } \\
\text { Handbook } 105-1 \text { (1990 Edition), "Specifications and Tolerances for Reference } \\
\text { Standards and Field Standard Weights and Measures," (Handbook 105-1). } \\
\text { These requirements are confirmed to be met by having National Type } \\
\text { Evaluation Program or Federal Grain Inspection Service type approval. Scales } \\
\text { used for commercial purposes will be required to meet only the applicable } \\
\text { requirements of the } 2002 \text { edition of the NIST Handbook } 44 \text {. Pursuant to the } \\
\text { provisions of } 5 \text { U.S.C. } 552 \text { (a), with the exception of the Handbook } 44 \\
\text { requirements listed in paragraph (b) of this section, the materials in Handbooks } \\
44 \text { and } 105-1 \text { are incorporated by reference as they exist on the date of } \\
\text { approval and a notice of any change in these materials will be published in the } \\
\text { Federal Register." }\end{array}$ & 1990 & USDA/GIPSA & 7 CFR 802.0(a) \\
\hline Handbook 44 & $\begin{array}{l}\text { Reference is made to NIST Handbook } 44 \text { to state that "All scales used by } \\
\text { stockyard owners, market agencies, dealers, packers, and live poultry dealers to } \\
\text { weigh livestock, livestock carcasses, live poultry, or feed for the purposes of } \\
\text { purchase, sale, acquisition, payment, or settlement shall be installed, maintained, } \\
\text { and operated to ensure accurate weights. Such scales shall meet applicable } \\
\text { requirements contained in the General Code, Scale Code, and Weights Code of } \\
\text { the } 1996 \text { edition of National Institute of Standards and Technology (NIST) } \\
\text { Handbook 44, "Specifications, Tolerances, and Other Technical Requirements } \\
\text { for Weighing and Measuring Devices," which is hereby incorporated by } \\
\text { reference." }\end{array}$ & 1996 & USDA/GIPSA & 9 CFR 201.71(a) \\
\hline
\end{tabular}




\begin{tabular}{|c|c|c|c|c|}
\hline Handbook 133 & $\begin{array}{l}\text { Reference is made to NIST Handbook } 133 \text { for purposes of definitions, and } \\
\text { procedures to be used in determining net weight and net weight compliance. } \\
\text { Certain sections of Handbook } 133 \text { are incorporated by reference, and this sub- } \\
\text { section states the exceptions (i.e., not incorporated by reference). This sub- } \\
\text { section states, in part, "definitions, and procedures to be used in determining net } \\
\text { weight and net weight compliance are described in the National Institute of } \\
\text { Standards and Technology (NIST) Handbook 133, "Checking the Net Contents } \\
\text { of Packaged Goods," Third Edition, September 1988, and Supplements } 1,2,3 \text {, } \\
\text { and } 4 \text { dated September 1990, October 1991, October 1992, and October 1994, } \\
\text { respectively, which are incorporated by reference, with the exception of the } \\
\text { NIST Handbook } 133 \text { and Supplements 1, 3, and } 4 \text { requirements listed in } \\
\text { paragraphs (b) and (c) of this section. Those provisions incorporated by } \\
\text { reference herein, are considered mandatory requirements." }\end{array}$ & 1988 & USDA/FSIS & 9 CFR 317.19(a) \\
\hline Handbook 133 & Excludes certain parts of Handbook 133 that are not relevant for this regulation. & & & 9 CFR 317.19(b) \\
\hline Handbook 133 & $\begin{array}{l}\text { Excludes certain requirements of Supplements 1, } 3 \text { and } 4 \text { of Handbook } 133 \text { that } \\
\text { are not relevant to this regulation. }\end{array}$ & & & 9 CFR 317.19(c) \\
\hline Handbook 44 & $\begin{array}{l}\text { Scale requirements for accurate weights, repairs, adjustments, and replacement } \\
\text { after inspection refer to NIST Handbook 44, and state that "All scales used to } \\
\text { weigh meat products sold or otherwise distributed in commerce in federally } \\
\text { inspected meat establishments shall be installed, maintained and operated to } \\
\text { insure accurate weights. Such scales shall meet the applicable requirements } \\
\text { contained in National Institute of Standards and Technology Handbook } 44, \\
\text { "Specifications, Tolerances, and Other Technical Requirements for Weighing } \\
\text { and Measuring Devices", 1999 Edition, November 1998, which is incorporated } \\
\text { by reference." (MANDATORY), incorporated by reference }\end{array}$ & 1998 & USDA/FSIS & 9 CFR 317.20(a) \\
\hline Handbook 44 & $\begin{array}{l}\text { As part of the regulations on labeling, marking devices and containers, this } \\
\text { regulation refers to NIST Handbook } 44 \text { to ensure accuracy of the weighing } \\
\text { scales and states that "No scale shall be used at a federally inspected } \\
\text { establishment to weigh meat products unless it has been found upon test and } \\
\text { inspection, as specified in NIST Handbook } 44 \text {, to provide accurate weight. If a } \\
\text { scale is reinspected or retested and found to be inaccurate, or if any repairs, } \\
\text { adjustments or replacements are made to a scale, it shall not be used until it has } \\
\text { been inspected and tested by a USDA official, or a State or local government } \\
\text { weights and measures official, or State registered or licensed scale repair firm or } \\
\text { person, and it must meet all accuracy requirements as specified in NIST } \\
\text { Handbook 44. If a USDA inspector has put a retain tag on a scale it can only be } \\
\text { removed by a USDA inspector. As long as the tag is on the scale, it shall not be } \\
\text { used."(MANDATORY) }\end{array}$ & & USDA/FSIS & 9 CFR 317.20 (c) \\
\hline
\end{tabular}




\begin{tabular}{|c|c|c|c|c|}
\hline Handbook 44 & $\begin{array}{l}\text { Reference is made to Handbook } 44 \text { in stating that "The operator of each official } \\
\text { establishment that weighs meat food products shall cause such scales to be tested } \\
\text { for accuracy, in accordance with the technical requirements of NIST Handbook } \\
44 \text {, at least once during the calendar year...." (MANDATORY) }\end{array}$ & & USDA/FSIS & 9CFR 317.21 (a) \\
\hline Handbook 44 & $\begin{array}{l}\text { Reference is made to Handbook } 44 \text { in stating that "The operator of each official } \\
\text { establishment shall display on or near each scale a valid certification of the } \\
\text { scale's accuracy from a State or local government's weights and measures } \\
\text { authority or from a State registered or licensed scale repair firm or person, or } \\
\text { shall have alternative documented procedures showing that the scale has been } \\
\text { tested for accuracy in accordance with the requirements of NIST Handbook 44." }\end{array}$ & & USDA/FSIS & 9CFR 317.21 (b) \\
\hline Handbook 133 & $\begin{array}{l}\text { In stating the definition and procedures for determining net weigh compliance in } \\
\text { regulations pertaining to poultry product inspections, reference is made to NIST } \\
\text { Handbook } 133 \text { as, "For the purpose of } \$ 381.121 \text { b of this part, the reasonable } \\
\text { variations allowed, definitions, and procedures to be used in determining net } \\
\text { weight and net weight compliance are described in the National Institute of } \\
\text { Standards and Technology (NIST) Handbook } 133 \text {, "Checking the Net Contents } \\
\text { of Packaged Goods," Third Edition, September 1988, and Supplements } 1,2,3 \text {, } \\
\text { and } 4 \text { dated September 1990, October } 1991 \text {, October 1992, and October 1994, } \\
\text { respectively, which are incorporated by reference, with the exception of the } \\
\text { NIST Handbook } 133 \text { and Supplements } 1 \text { and } 3 \text { requirements listed in paragraphs } \\
\text { (b) and (c) of this section. Those provisions, incorporated by reference herein, } \\
\text { are considered mandatory requirements" }\end{array}$ & 1988 & USDA/FSIS & 9 CFR $381.121 b(a)$ \\
\hline Handbook 133 & $\begin{array}{l}\text { In stating the definition and procedures for determining net weigh compliance in } \\
\text { regulations pertaining to poultry product inspections, specifies those } \\
\text { requirements of NIST Handbook } 133 \text { that are not incorporated by reference (In } \\
\text { context of Handbook } 133 \text { and its supplements IBR as stated in } 9 \text { CFR } \\
381.121 \text { b(a) }\end{array}$ & & USDA/FSIS & 9 CFR 381.121b(b) \\
\hline Handbook 133 & $\begin{array}{l}\text { In stating the definition and procedures for determining net weigh compliance in } \\
\text { regulations pertaining to poultry product inspections, specifies those } \\
\text { requirements of Supplement } 1 \text { dated September 1990, Supplement } 3 \text { dated } \\
\text { October 1992, and Supplement } 4 \text { dated October 1994, of NIST Handbook } 133 \\
\text { that are not incorporated by reference (In context of Handbook } 133 \text { and its } \\
\text { supplements IBR as stated in } 9 \text { CFR } 381.121 \text { b(a). }\end{array}$ & & USDA/FSIS & 9 CFR 381.121b(c) \\
\hline
\end{tabular}




\begin{tabular}{|c|c|c|c|c|}
\hline Handbook 44 & $\begin{array}{l}\text { Defining the scale requirements for accurate weights, repairs, adjustment, and } \\
\text { replacement after inspection, this regulation requires that "All scales used to } \\
\text { weight poultry products sold or otherwise distributed in commerce in federally } \\
\text { inspected poultry plants shall be installed, maintained, and operated to insure } \\
\text { accurate weights. Such scales shall meet the applicable requirements contained } \\
\text { in National Institute of Standards and Technology (NIST) Handbook 44, } \\
\text { "Specifications, Tolerances, and Other Technical Requirements for Weighing } \\
\text { and Measuring Devices", 1999 Edition, November 1998, which is incorporated } \\
\text { by reference...."(MANDATORY), incorporated by reference }\end{array}$ & 1998 & USDA/FSIS & 9 CFR $381.121 \mathrm{c}(\mathrm{a})$ \\
\hline Handbook 44 & $\begin{array}{l}\text { Defining the scale requirements for accurate weights, repairs, adjustment, and } \\
\text { replacement after inspection, this regulation requires that "No scale shall be used } \\
\text { at a federally inspected establishment to weigh poultry products unless it has } \\
\text { been found upon test and inspection as specified in NIST Handbook } 44 \text { to } \\
\text { provide accurate weight. If a scale is inspected or tested and found to be } \\
\text { inaccurate, or if any repairs, adjustments or replacements are made to a scale, it } \\
\text { shall not be used until it has been reinspected and retested by a USDA official, } \\
\text { or a State or local government weights and measures official, or a State } \\
\text { registered or licensed scale repair firm or person, and it must meet all accuracy } \\
\text { requirements as specified in NIST Handbook 44". }\end{array}$ & 1998 & USDA/FSIS & 9 CFR $381.121 \mathrm{c}(\mathrm{c})$ \\
\hline Handbook 44 & $\begin{array}{l}\text { Reference is made to NIST Handbook } 44 \text { to state that "he operator of each } \\
\text { official establishment that weighs poultry food products shall cause such scales } \\
\text { to be tested for accuracy in accordance with the technical requirements of NIST } \\
\text { Handbook 44, at least once during the calendar year". It is further required that } \\
\text { "The operator of each official establishment shall display on or near each scale a } \\
\text { valid certification of the scale's accuracy from a State or local government's } \\
\text { weights and measures authority or from a State registered or licensed scale } \\
\text { repair firm or person, or shall have alternative documented procedures showing } \\
\text { that the scale has been tested for accuracy in accordance with the requirements } \\
\text { of NIST Handbook 44." (MANDATORY) }\end{array}$ & & USDA/FSIS & 9 CFR 381.121d \\
\hline NBS Handbook 69 & $\begin{array}{l}\text { Radiation exposure, " Determination of exclusion area, low population zone, and } \\
\text { population center distance."- Refers to the NBS Handbook 69(1959) in } \\
\text { reference to determination of radiation exposure for determination of exclusion } \\
\text { area, low population zone and population center distance as part of Reactor Site } \\
\text { criteria. }\end{array}$ & 1959 & $\mathrm{DOE} / \mathrm{NRC}$ & 10 CFR 100.11 \\
\hline
\end{tabular}




\begin{tabular}{|c|c|c|c|c|}
\hline Handbook 136 & $\begin{array}{l}\text { In defining the minimum criteria for equipment used in industrial radiographic } \\
\text { operations, this regulation refers to NBS Handbook 136, and states that "Each } \\
\text { radiographic exposure device, source assembly or sealed source, and all } \\
\text { associated equipment must meet the requirements specified in American } \\
\text { National Standards Institute, N432-1980 "Radiological Safety for the Design } \\
\text { and Construction of Apparatus for Gamma Radiography," (published as NBS } \\
\text { Handbook 136, issued January 1981). This publication has been approved for } \\
\text { incorporation by reference....." (MANDATORY), Incorporated by Reference }\end{array}$ & 1981 & $\mathrm{DOE} / \mathrm{NRC}$ & 10 CFR 34.20(a)(1) \\
\hline Calibration & $\begin{array}{l}\text { This regulation requires that dosimetry equipment must be calibrated using a } \\
\text { system or source traceable to NIST as one option of a condition to be met. The } \\
\text { second condition that needs to be satisfied requires that "the system must have } \\
\text { been calibrated within the previous } 4 \text { years. Eighteen to thirty months after that } \\
\text { calibration, the system must have been intercompared with another dosimetry } \\
\text { system that was calibrated within the past } 24 \text { months by NIST or by a calibration } \\
\text { laboratory accredited by the AAPM - American Association of Physicists in } \\
\text { Medicine." }\end{array}$ & & DOE/NRC & 10 CFR 35.630(a)(1,2) \\
\hline Handbook 150-01 & $\begin{array}{l}\text { Reference is made to the "NVLAP Handbook 150-01, "Energy Efficient } \\
\text { Lighting Products, Lamps and Luminaires, August 1993" }\end{array}$ & 1993 & $\begin{array}{l}\text { DOE/Energy } \\
\text { Conservation }\end{array}$ & 10 CFR 430.22(c)(2) \\
\hline Calibration & $\begin{array}{l}\text { In defining the test methods and measurements as part of the Uniform Test } \\
\text { Method for Measuring Average Lamp Efficacy (LE) and Color Rendering Index } \\
\text { (CRI) of Electric Lamps, this regulation requires that "all lumen measurements } \\
\text { made with instruments calibrated to the devalued NIST lumen after January 1, } \\
\text { 1996, shall be multiplied by 1.011" }\end{array}$ & & DOE & $\begin{array}{l}\text { Appendix R to Subpart B } \\
\text { of } 10 \text { CFR } 430 \text { (4) }\end{array}$ \\
\hline Handbooks $150,150-10$ & $\begin{array}{l}\text { Reference is made to NIST Handbook } 150 \text { "National Voluntary Laboratory } \\
\text { Accreditation Program Procedures and General Requirements," and Handbook } \\
150-10 \text { (supplement to Handbook 150,08/1995) in referring to the technical } \\
\text { requirements of the National Voluntary Laboratory Accreditation Program for } \\
\text { the Efficiency of Electric Motors field of accreditation (Supplement 150-10), } \\
\text { and all general NIST/NVLAP procedures, criteria, and policies (Handbook } \\
\text { 150). }\end{array}$ & & $\begin{array}{l}\text { DOE/Energy } \\
\text { Efficiency }\end{array}$ & 10 CFR 431.25 \\
\hline NVLAP & $\begin{array}{l}\text { Reference is made to the NVLAP program as the accreditation body of which } \\
\text { accredits laboratories where testing for the Energy Efficiency Program can be } \\
\text { conducted. It also recognizes laboratories accredited by ABs having a MRA with } \\
\text { NVLAP for testing of Efficiency of Electrical Motors. }\end{array}$ & & $\begin{array}{l}\text { DOE/Energy } \\
\text { Efficiency }\end{array}$ & 10 CFR 431.25 \\
\hline
\end{tabular}




\begin{tabular}{|c|c|c|c|c|}
\hline NIST $85-3273$ & $\begin{array}{l}\text { Reference is made to NIST Publication (NIST IR 85-3273) "Life Cycle Costing } \\
\text { Manual for Federal Energy Management Program" in stating the methodological } \\
\text { assumptions for "estimating and comparing the life cycle costs of Federal } \\
\text { buildings, for determining the life cycle cost effectiveness of energy } \\
\text { conservation measures and water conservation measures, and for rank ordering } \\
\text { life cycle cost effective measures in order to design a new Federal building or to } \\
\text { retrofit an existing Federal building." }\end{array}$ & & $\begin{array}{l}\text { DOE/Energy } \\
\text { Conservation }\end{array}$ & 10 CFR 436.14(a) \\
\hline NBS Handbook 69 & $\begin{array}{l}\text { Reference is made to NBS Handbook } 69 \text { dated June } 5,1959 \text {, in the context of } \\
\text { determination of radiation exposure status. The citation reads "A whole body } \\
\text { dose of } 25 \text { rem has been stated to correspond numerically to the once in a } \\
\text { lifetime accidental or emergency dose for radiation workers which, according to } \\
\text { NCRP recommendations at the time could be disregarded in the determination of } \\
\text { their radiation exposure status (see NBS Handbook } 69 \text { dated June } 5,1959 \text { ). } \\
\text { However, its use is not intended to imply that this number constitutes an } \\
\text { acceptable limit for an emergency dose to the public under accident conditions. } \\
\text { Rather, this dose value has been set forth in this section as a reference value, } \\
\text { which can be used in the evaluation of plant design features with respect to } \\
\text { postulated reactor accidents, in order to assure that such designs provide } \\
\text { assurance of low risk of public exposure to radiation, in the event of such } \\
\text { accidents" }\end{array}$ & 1959 & DOE/NRC & 10 CFR 50.34(a)(7) \\
\hline Traceability & $\begin{array}{l}\text { This regulation states the requirements for calibration and checking of } \\
\text { measurement systems used in the "Measurement of Airplane Noise Received on } \\
\text { the Ground". In particular, this regulation states that "Within six months of each } \\
\text { test series the output of the noise generator must be determined by a method } \\
\text { traceable to the U.S. National Institute of Standards and Technology or to an } \\
\text { equivalent national standards laboratory as determined by the FAA...". }\end{array}$ & & DOT/FAA & $\begin{array}{l}\text { 14 CFR 36 Appendix A } \\
\text { (A36.3.9.5) }\end{array}$ \\
\hline Traceability & $\begin{array}{l}\text { This regulation states the requirements for calibration and checking of } \\
\text { measurement systems used in the "Measurement of Airplane Noise Received on } \\
\text { the Ground". In particular, this regulation states that "Within six months of each } \\
\text { test series the output of the sound calibrator must be determined by a method } \\
\text { traceable to the U.S. National Institute of Standards and Technology or to an } \\
\text { equivalent national standards laboratory as determined by the FAA...". }\end{array}$ & & DOT/FAA & $\begin{array}{l}\text { 14 CFR 36 Appendix A } \\
\text { (A36.3.9.7) }\end{array}$ \\
\hline Traceability & $\begin{array}{l}\text { This regulation states the requirements for calibration and checking of } \\
\text { measurement systems used in the "Measurement of Airplane Noise Received on } \\
\text { the Ground". In particular, this regulation states that "Alternatively, within six } \\
\text { months of each test series the insertion loss of the windscreen may be } \\
\text { determined by a method traceable to the U.S. National Institute of Standards and } \\
\text { Technology or an equivalent national standards laboratory as determined by the } \\
\text { FAA...". }\end{array}$ & & DOT/FAA & $\begin{array}{l}\text { 14 CFR Appendix H } \\
\text { A36.3.9.10 }\end{array}$ \\
\hline
\end{tabular}




\begin{tabular}{|c|c|c|c|c|}
\hline & $\begin{array}{l}\text { In defining the calibrations required while measuring helicopter noise received } \\
\text { at the ground, this section in the Appendix requires that "A performance } \\
\text { calibration analysis of each piece of calibration equipment, including } \\
\text { pistonphones, reference microphones, and voltage insert devices, must have } \\
\text { been made during the six calendar months preceding the beginning of each day's } \\
\text { test series. Each calibration must be traceable to the National Bureau of } \\
\text { Standards."(MANDATORY) }\end{array}$ & & DOT/FAA & $\begin{array}{l}\text { 14 CFR Appendix H } \\
\text { H36.109 (e)(7) }\end{array}$ \\
\hline Traceability & $\begin{array}{l}\text { This section of the Appendix to the regulation pertains to measurement of } \\
\text { helicopter noise received on the ground. In defining the calibration requirements } \\
\text { of the measuring system and components of the recording system, the regulation } \\
\text { states that "A performance calibration analysis of each piece of calibration } \\
\text { equipment, including acoustic calibrators, reference microphones, and voltage } \\
\text { insertion devices, must have been made during the six calendar months } \\
\text { preceding the beginning of the helicopter flyover series. Each calibration shall } \\
\text { be traceable to the National Institute of Standards and } \\
\text { Technology."(MANDATORY) }\end{array}$ & & DOT/FAA & $\begin{array}{l}\text { 14 CFR 36 Appendix J } \\
\text { (J36.107 (e)(2)(iii)) }\end{array}$ \\
\hline Calibration & $\begin{array}{l}\text { As part of the specifications in the Test Method To Determine the Flammability } \\
\text { and Flame Propagation Characteristics of Thermal/Acoustic Insulation Materials } \\
\text { when exposed to both a radiant heat source and a flame, this part (Part VI, } \\
\text { Appendix F to 14CFR25) requires that the standard transducer used for the } \\
\text { calorimeter calibration, must in turn be calibrated against a primary standard } \\
\text { traceable to NIST. }\end{array}$ & & DOT/FAA & $\begin{array}{l}\text { 14 CFR } 25 \text { Appendix F } \\
\text { PartVI(b)(7)(ii)(C) }\end{array}$ \\
\hline SP 250 & $\begin{array}{l}\text { This regulation states that "NIST Special Publication } 250 \text {, "Calibration and } \\
\text { Related Measurement Services of the National Institute of Standards \& } \\
\text { Technology" is hereby incorporated by reference, pursuant to } 5 \text { U.S.C. } \\
552(a)(1) \text { and } 1 \text { CFR Part } 51 \text {. SP } 250 \text { states the authority under which NIST } \\
\text { performs various types of measurement services including calibrations and tests } \\
\text { and charges fees therefore, states the general conditions under which the public } \\
\text { may secure such services, describes these services in considerable detail, and } \\
\text { lists the fees to be charged, and sets out the instructions for requesting them in } \\
\text { an appendix which is reviewed, revised and reissued semi-annually (December } \\
\text { and June). The Director, Office of the Federal Register, approved the } \\
\text { incorporation by reference on December } 28,1967 . "\end{array}$ & NDG & DOC/NIST & 15 CFR 200.115(a) \\
\hline SP 260 & $\begin{array}{l}\text { This regulation provides a description of NIST Special Publication } 260 \text {, } \\
\text { "Catalog of NIST Standard Reference Materials," and specifies that SP260 its } \\
\text { supplement are incorporated by reference pursuant to } 5 \text { U.S.C. 552(a)(1) and } 1 \\
\text { CFR Part } 51\end{array}$ & NDG & DOC/NIST & 15 CFR 230.7(a) \\
\hline Accreditation & $\begin{array}{l}\text { This regulation states the procedures for petitioning for approval of documents } \\
\text { related to certification, accreditation, laboratory accreditation and approval of } \\
\text { accreditation bodies in support of the Fastener Quality Act. }\end{array}$ & & DOC/NIST & 15 CFR 280.101 \\
\hline
\end{tabular}




\begin{tabular}{|c|c|c|c|}
\hline Accreditation & $\begin{array}{l}\text { This regulation in support of the Fastener Quality Act requires that "An } \\
\text { accreditation body accrediting third parties who certify manufacturing systems } \\
\text { as fastener quality assurance systems as described in section } 3(7)(\mathrm{B})(\mathrm{iii})(\mathrm{I}) \text { of the } \\
\text { Act ( } 15 \text { U.S.C. } 5402(7)(\mathrm{B})(\mathrm{iii})(\mathrm{I})) \text { shall affirm to the Director, NIST, that it } \\
\text { meets the requirements of ISO/IEC Guide } 61 \text { " and similarly, "An accreditation } \\
\text { body accrediting laboratories as described in section 3(1)(B) of the Act (15 } \\
\text { U.S.C. } 5402(1)(\mathrm{B}) \text { ) shall affirm to the Director, NIST, that it meets the } \\
\text { requirements of ISO/IEC Guide 58". }\end{array}$ & DOC/NIST & 15 CFR 280.102 \\
\hline NTTAA & $\begin{array}{l}\text { This regulation states the responsibilities of the National Institute of Standards } \\
\text { and Technology pertaining to the ICSP to coordinate Federal, state and local } \\
\text { conformity assessment activities with private sector conformity assessment } \\
\text { activities (Guidance on Federal Conformity Assessment, under Authority of } \\
\text { Section 12, PL 104-113). }\end{array}$ & DOC/NIST & 15 CFR 287.3 \\
\hline NTTAA & $\begin{array}{l}\text { This regulation states the responsibilities of Federal agencies pertaining to their } \\
\text { role under the ICSP in working with NIST and private sector bodies. (Guidance } \\
\text { on Federal Conformity Assessment, under Authority of Section 12, PL 104- } \\
\text { 113). }\end{array}$ & DOC/NIST & 15 CFR 287.4 \\
\hline NTTAA & $\begin{array}{l}\text { Defines the responsibilities of Agency Standards Executive vis-à-vis working } \\
\text { with NIST under the ICSP pertaining to the ICSP to coordinate Federal, state } \\
\text { and local conformity assessment activities with private sector conformity } \\
\text { assessment activities (Guidance on Federal Conformity Assessment, under } \\
\text { Authority of Section 12, PL 104-113). }\end{array}$ & DOC/NIST & \\
\hline NBS Calibration & $\begin{array}{l}\text { This regulation stipulates the procedures used to calibrate radiation instruments } \\
\text { used in test procedures for measuring critical radiant flux. The procedures state } \\
\text { that for total heat flux meters "the total flux meter shall be calibrated by the } \\
\text { National Bureau of Standards, (direct request for such calibration services to the: } \\
\text { Radiometric Physics Division, 534, National Bureau of Standards (NBS), } \\
\text { Washington, DC 20234.), or, alternatively, its calibration shall be developed by } \\
\text { transfer calibration methods with an NBS calibrated flux } \\
\text { meter."...(MANDATORY). These procedures are stated as part of the interim } \\
\text { safety standards for cellulose insulation. }\end{array}$ & CPSC & 16 CFR 1209.8(b) \\
\hline Unknown & $\begin{array}{l}\text { This regulation states that "The National Bureau of Standards in } 1972 \text { estimated } \\
\text { that } 600,000 \text { young children have unduly high lead blood content" as part of the } \\
\text { CPSC's findings about the risk of injury to children due to lead poisoning. No } \\
\text { further reference is made to the source of this information, i.e., no citation. }\end{array}$ & CPSC & 16 CFR 1303.5(a)(5) \\
\hline Handbook 28 & $\begin{array}{l}\text { Refers to NBS Publication Handbook H28 "Screw Thread Standards for Federal } \\
\text { Service"- } 1512 \text { to specify mechanical requirements for attachment hardware } \\
\text { under requirements for bicycles. The regulation states "All threaded hardware } \\
\text { shall be of sufficient quality to allow adjustments and maintenance. } \\
\text { Recommended quality thread form is specified in Handbook H28..." }\end{array}$ & CPSC & 16 CFR 1512.4(d) \\
\hline
\end{tabular}




\begin{tabular}{|c|c|c|c|c|}
\hline $\begin{array}{l}\text { NIST report - NIST Test } \\
\text { Procedure published through } \\
\text { API }\end{array}$ & $\begin{array}{l}\text { To determine the substantial equivalency of processed used oil with new oil for } \\
\text { use as engine oil, manufacturers or their designees must use the test } \\
\text { procedures that were reported to the Commission by the National Institute of } \\
\text { Standards and Technology ("NIST") on July 27, 1995, entitled "Engine Oil } \\
\text { Licensing and Certification System," American Petroleum Institute ("API") } \\
\text { Publication 1509, Thirteenth Edition, January, 1995. Incorporated by } \\
\text { Reference(MANDATORY) }\end{array}$ & 1995 & FTC & 16 CFR 311.4 \\
\hline $\begin{array}{l}\text { NIST report - NIST Test } \\
\text { Procedure published through } \\
\text { API }\end{array}$ & $\begin{array}{l}\text { Labeling requirements - A manufacturer or other seller may represent, on a } \\
\text { label on a container of processed used oil, that such oil is substantially } \\
\text { equivalent to new oil for use as engine oil only if the manufacturer has } \\
\text { determined that the oil is substantially equivalent to new oil for use as engine oil } \\
\text { in accordance with the NIST test procedures prescribed under } \$ 311.4 \text { of this } \\
\text { part, and has based the representation on that determination (MANDATORY). }\end{array}$ & 1995 & FTC & 16 CFR 311.5 \\
\hline $\begin{array}{l}\text { NIST test procedures- used to } \\
\text { establish penalties in case of } \\
\text { non-compliance }\end{array}$ & $\begin{array}{l}\text { Prohibited acts - A manufacturer or other seller may represent, on a label on a } \\
\text { container of processed used oil, that such oil is substantially equivalent to new } \\
\text { oil for use as engine oil only if the manufacturer has determined that the oil is } \\
\text { substantially equivalent to new oil for use as engine oil in accordance with the } \\
\text { NIST test procedures prescribed under } \S 311.4 \text { of this part, and has based the } \\
\text { representation on that determination(MANDATORY) }\end{array}$ & 1996 & FTC & 16 CFR 311.6 \\
\hline $\begin{array}{l}\text { NBS Voluntary Product } \\
\text { Standard } 36-70\end{array}$ & $\begin{array}{l}\text { "Body Measurements for Sizing Boys Apparel (formerly CS 155-50)" - The } \\
\text { CPSC uses the stated NBS voluntary product standard for defining "tight-fitting } \\
\text { garments" in their standard for flammability of children's sleepwear. The NBS } \\
\text { Voluntary standard covers standard size designations, size classifications, and } \\
\text { body measurements for the sizing of boys' apparel. }\end{array}$ & 1971 & CPSC & 16 CFR 1616.2(b) \\
\hline $\begin{array}{l}\text { NBS Voluntary Product } \\
\text { Standard } 54-72\end{array}$ & $\begin{array}{l}\text { "Body Measurements for Sizing Girls Apparel (sizes 7-14) (formerly CS 153- } \\
\text { 48)" - The CPSC uses the stated NBS voluntary product standard for defining } \\
\text { "tight-fitting garments" in their standard that provides a test method to determine } \\
\text { flammability of children's sleepwear (sizes 7-14). This Voluntary Product } \\
\text { Standard establishes a nationally recognized sizing system for girls, based on } \\
\text { body measurements. }\end{array}$ & 1973 & CPSC & 16 CFR 1616.2(b) \\
\hline
\end{tabular}

\section{Appendix 22}




\begin{tabular}{|c|c|c|c|c|}
\hline NBSIR 84-7833 & $\begin{array}{l}\text { Regulation refers to guidelines in NBSIR } 84-2833 \text { "Data requirements for the } \\
\text { Seismic Review of LNG facilities" to produce the required report on earthquake } \\
\text { hazards and engineering, "if the LNG import/export facility is to be located at a } \\
\text { site in zones 2, 3, or } 4 \text { of the Uniform Building Code's Seismic Risk Map of the } \\
\text { United States, or where there is a risk of surface faulting or ground liquefaction" } \\
\text { in filing Applications for Authorization to Construct, Operate or Modify } \\
\text { Facilities Used for the Export or Import of Natural Gas".(MANDATORY) }\end{array}$ & & FERC & 18 CFR 153.8(a)(6) \\
\hline Security guidelines & $\begin{array}{l}\text { This regulation refers to guidelines developed by the DoC(NBS) and other } \\
\text { government agencies to ensure safety of information in manual and computer } \\
\text { based systems. The regulation states that "whenever records in the manual or } \\
\text { computer-based record systems, including input and output documents, punched } \\
\text { cards, and magnetic tapes or disks, are not under the personal control of an } \\
\text { authorized person, they will be stored in lockable containers and/or in a secured } \\
\text { room, or in alternative storage systems which furnish an equivalent or greater } \\
\text { degree of physical security. In this regard, the Commission may refer to security } \\
\text { guidelines prepared by the General Services Administration, the Department of } \\
\text { Commerce (National Bureau of Standards), or other agencies with appropriate } \\
\text { knowledge and expertise". }\end{array}$ & & FERC & 18 CFR 3b.204(b) \\
\hline Handbook 44 & $\begin{array}{l}\text { Measure Container Code, section } 4.45 \text { Measure Containers; Exemptions from } \\
\text { required label statements - Mentions that certain frozen foods "when measured } \\
\text { by and packaged in } 1 / 2 \text {-liquid pint and } 1 / 2 \text {-gallon measure-containers, as defined } \\
\text { in the "Measure Container Code of National Bureau of Standards Handbook } 44, " \\
\text { Specifications, Tolerances, and Other Technical Requirements for Weighing and } \\
\text { Measuring Devices, Sec. } 4.45 \text { "Measure-Containers," which is incorporated by } \\
\text { reference, are exempt from the requirements of } \S 101.105(b)(2) \text { of this chapter } \\
\text { (i.e., that statements of fluid measure shall be in terms of the U.S. gallon of } 231 \\
\text { cubic inches and quart, pint, and fluid ounce subdivisions thereof, and shall (i) In } \\
\text { the case of frozen food that is sold and consumed in a frozen state, express the } \\
\text { volume at the frozen temperature.) to the extent that net contents of } 8 \text {-fluid } \\
\text { ounces and 64-fluid ounces (or } 2 \text { quarts) may be expressed as } 1 / 2 \text { pint and } 1 / 2 \\
\text { gallon. }\end{array}$ & NDG & HHS/FDA & 21 CFR 1.24(a)(6)(i) \\
\hline Handbook 44 & $\begin{array}{l}\text { Measure Container Code, section } 4.45 \text { Measure Containers; Exemptions from } \\
\text { required label statements - mentions that the certain frozen foods referred to in } \\
21 \text { CFR1.24(a)(6)(i) when measured by and packaged in 1-liquid pint, 1-liquid } \\
\text { quart, and 1/2-gallon measure-containers, as defined in the "Measure Container } \\
\text { Code of National Bureau of Standards Handbook } 44, " \text { Specifications, } \\
\text { Tolerances, and Other Technical Requirements for Weighing and Measuring } \\
\text { Devices, Sec. } 4.45 \text { "Measure-Containers," which is incorporated by reference, } \\
\text { are exempt from the dual net-contents declaration requirement of } \S 101.105(\mathrm{j}) \\
\text { containing labeling requirements for packages containing less than } 4 \text { pounds or } 1 \\
\text { gallon and labeled in terms of weight or fluid measure. }\end{array}$ & NDG & HHS/FDA & 21 CFR 1.24(a)(6)(ii) \\
\hline
\end{tabular}




\begin{tabular}{|c|c|c|c|c|}
\hline Handbook 44 & $\begin{array}{l}\text { Measure Container Code, section } 4.45 \text { Measure Containers; Exemptions from } \\
\text { required label statements - Mentions that frozen foods referred in } 21 \\
\text { CFR1.24(a)(6)(i) when measured by and packaged in 1/2-liquid pint, 1-liquid } \\
\text { pint, 1-liquid quart, } 1 / 2 \text {-gallon, and 1-gallon measured-containers, as defined in } \\
\text { the "Measure Container Code of National Bureau of Standards Handbook 44," } \\
\text { Specifications, Tolerances, and Other Technical Requirements for Weighing and } \\
\text { Measuring Devices, Sec. } 4.45 \text { "Measure-Containers," which is incorporated by } \\
\text { reference, are exempt from the requirement of } \S 101.105 \text { (f) (i.e., The } \\
\text { declaration shall appear as a distinct item on the principal display panel, shall be } \\
\text { separated (by at least a space equal to the height of the lettering used in the } \\
\text { declaration) from other printed label information appearing above or below the } \\
\text { declaration and (by at least a space equal to twice the width of the letter "N" of } \\
\text { the style of type used in the quantity of contents statement) from other printed } \\
\text { label information appearing to the left or right of the declaration. It shall not } \\
\text { include any term qualifying a unit of weight, measure, or count (such as "jumbo } \\
\text { quart" and "full gallon") that tends to exaggerate the amount of the food in the } \\
\text { container. It shall be placed on the principal display panel within the bottom } 30 \\
\text { percent of the area of the label panel in lines generally parallel to the base on } \\
\text { which the package rests as it is designed to be displayed: Provided, That on } \\
\text { packages having a principal display panel of } 5 \text { square inches or less, the } \\
\text { requirement for placement within the bottom } 30 \text { percent of the area of the label } \\
\text { panel shall not apply when the declaration of net quantity of contents meets the } \\
\text { other requirements of this part.) }\end{array}$ & NDG & HHS/FDA & 21 CFR 1.24(a)(6)(iii) \\
\hline Circular 484 & $\begin{array}{l}\text { Spectrophotometry - Refers to NBS Circular } 484 \text { (incorporated by reference), } \\
\text { for establishing the absorbance accuracy (performance requirement) of a } \\
\text { spectophotometer used for determination of ultraviolet absorbance of petroleum } \\
\text { naptha. The regulation specifies the ultraviolet absorbance limits of petroleum } \\
\text { naptha that can be used in or on foods. }\end{array}$ & 1949 & HHS/FDA & 21 CFR 172.250(b)(3) \\
\hline Circular 484 & $\begin{array}{l}\text { Spectrophotometry - Refers to NBS Circular } 484 \text { (incorporated by reference), } \\
\text { for establishing the absorbance accuracy (performance requirement) of a } \\
\text { spectophotometer used for determination of ultraviolet absorbance of synthetic } \\
\text { fatty alcohols. The regulation specifies the ultraviolet absorbance limits of } \\
\text { synthetic fatty alcohols (for safe use) that can be used in or on foods. }\end{array}$ & & HHS/FDA & 21 CFR 172.864 \\
\hline Circular 484 & $\begin{array}{l}\text { Spectrophotometry - Refers to NBS Circular } 484 \text { (incorporated by reference), } \\
\text { for establishing the absorbance accuracy (performance requirement) of a } \\
\text { spectophotometer used for determination of ultraviolet absorbance of petroleum } \\
\text { wax. The regulation specifies the ultraviolet absorbance limits of petroleum wax } \\
\text { (for safe use) that can be used in or on foods. }\end{array}$ & 1949 & HHS/FDA & 21 CFR 172.886 \\
\hline
\end{tabular}




\begin{tabular}{|c|c|c|c|c|}
\hline NBS Material No. 577 & $\begin{array}{l}\text { Specifies spectrophotometric measurements as "All measurements are made in } \\
\text { an ultraviolet spectrophotometer in optical cells of } 5 \text { centimeters in length, and } \\
\text { in the range of } 255 \text { millimicrons to } 310 \text { millimicrons, under the same } \\
\text { instrumental conditions. The standard reference absorbance is the absorbance at } \\
275 \text { millimicrons of a standard reference solution of naphthalene (National } \\
\text { Bureau of Standards Material No. } 577 \text { or equivalent in purity) containing a } \\
\text { concentration of } 1.4 \text { milligrams per liter in purified isooctane, measured against } \\
\text { isooctane of the same spectral purity in 5-centimeter cells. (This absorbance will } \\
\text { be approximately } 0.30 .) \text { " as a test for compliance that food additive combustion } \\
\text { product gas may be safely used in the processing and packaging of the foods for } \\
\text { the purpose of removing and displacing oxygen. }\end{array}$ & & HHS/FDA & 21 CFR 173.350(e) \\
\hline Circular 484 & $\begin{array}{l}\text { Refers to NBS Circular } 484 \text { (incorporated by reference), for establishing the } \\
\text { absorbance accuracy (performance requirement) of a spectophotometer using } \\
\text { potassium chromate for reference standard; used for determination of ultraviolet } \\
\text { absorbance of mineral oil. The regulation specifies the ultraviolet absorbance } \\
\text { limits of mineral oil that can be safely used as a component of nonfood articles } \\
\text { intended for use in contact with food. }\end{array}$ & & HHS/FDA & $\begin{array}{l}21 \mathrm{CFR} \\
178.3620(\mathrm{c})(3)(\mathrm{iii})\end{array}$ \\
\hline Circular 484 & $\begin{array}{l}\text { Refers to "National Bureau of Standards Circular 484, Spectrophotometry, U.S. } \\
\text { Department of Commerce, 1949" for establishing procedure used to determine } \\
\text { accuracy of absorbance limits in the analytical method for determining } \\
\text { ultraviolet absorbance limits and pyrene content of mineral oil that can be safely } \\
\text { used as a component of nonfood articles intended for use in contact with food. }\end{array}$ & & HHS/FDA & $\begin{array}{l}21 \text { CFR } \\
178.3620(d)(3)(I)(F)\end{array}$ \\
\hline Circular 484 & $\begin{array}{l}\text { Spectrophotometry - Refers to a procedure described NBS Circular } 484 \\
\text { (incorporated by reference); for determination of UV absorbance accuracy of } \\
\text { spectrophotometer while establishing accuracy limits in measurement of } \\
\text { polyhydric alcohol esters of oxidatively refined (Gersthofen process) montan } \\
\text { wax in order to be safely used as components of articles intended for use in } \\
\text { contact with food. }\end{array}$ & 1949 & HHS/FDA & 21 CFR 178.3770(a)(4) \\
\hline Circular 484 & $\begin{array}{l}\text { Spectrophotometry -refers to NBS circular } 484 \text { (incorporated by reference) for } \\
\text { establishing the absorbance accuracy (performance requirement) of a } \\
\text { spectophotometer used for determination of ultraviolet absorbance of lubricants. } \\
\text { The regulation specifies the ultraviolet absorbance limits for safe use of } \\
\text { lubricants used in the manufacture of metallic articles that contact foods. }\end{array}$ & 1949 & HHS/FDA & $\begin{array}{l}21 \text { CFR } \\
178.3910(a)(4)(\text { iii) }\end{array}$ \\
\hline Voluntary Product Standard & $\begin{array}{l}\text { Definition of voluntary product standards- states that "If there exists a voluntary } \\
\text { product standard promulgated pursuant to the procedures found in } 15 \text { CFR part } \\
10 \text { by the Department of Commerce, quantitatively defining the meaning of the } \\
\text { term serving with respect to a particular food, then any label representation as to } \\
\text { the number of servings in such packaged food shall correspond with such } \\
\text { quantitative definition. (Copies of published standards are available upon request } \\
\text { from the National Bureau of Standards, Department of Commerce, Washington, } \\
\text { DC 20234.)" }\end{array}$ & & HHS/FDA & 21 CFR 501.8(b) \\
\hline
\end{tabular}




\begin{tabular}{|c|c|c|c|c|}
\hline Traceability & $\begin{array}{l}\text { An audiometer calibration set is identified as "a device that consists of an } \\
\text { acoustic cavity of known volume, a sound level meter, a microphone with } \\
\text { calibration traceable to the National Bureau of Standards, oscillators, frequency } \\
\text { counters, microphone amplifiers, and a recorder. The device can measure } \\
\text { selected audiometer test frequencies at a given intensity level, and selectable } \\
\text { audiometer attenuation settings at a given test frequency." This is within the } \\
\text { context of identification of diagnostic devices, particularly Ear, Nose and Throat } \\
\text { devices. }\end{array}$ & & HHS/FDA & 21 CFR 874.1080(a) \\
\hline Traceability / calibration & $\begin{array}{l}\text { This sub-section defines "Traceable to a national standard means an instrument } \\
\text { is calibrated at either the National Institute of Standards and Technology (NIST) } \\
\text { or at a calibration laboratory that participates in a proficiency program with } \\
\text { NIST at least once every } 2 \text { years and the results of the proficiency test conducted } \\
\text { within } 24 \text { months of calibration show agreement within } \pm 3 \text { percent of the } \\
\text { national standard in the mammography energy range." }\end{array}$ & & HHS/FDA & 21 CFR 900.2 \\
\hline NBS Publication & $\begin{array}{l}\text { As per the Privacy Act of 1974, this regulation states that amongst other } \\
\text { requirements "when the records subject to the Act are maintained in } \\
\text { computerized form, safeguards shall be utilized based on those recommended in } \\
\text { the National Bureau of Standard's booklet "Computer Security Guidelines for } \\
\text { Implementing the Privacy Act of 1974" (May 30, 1975), and any supplements } \\
\text { thereto, which are adequate and appropriate to assuring the integrity of the } \\
\text { records". "The Act requires that records subject to the Act be maintained with } \\
\text { appropriate administrative, technical and physical safeguards to ensure the } \\
\text { security and confidentiality of records and to protect against any anticipated } \\
\text { threats or hazards to their security or integrity which could result in substantial } \\
\text { harm, embarrassment, inconvenience or unfairness to any individual on whom } \\
\text { information is maintained". }\end{array}$ & & & 22 CFR 1101.5(c) \\
\hline Accreditation & $\begin{array}{l}\text { Reference is made to the NVLAP program in stating that HUD may require } \\
\text { accreditation of testing laboratories for certain products by a program such as the } \\
\text { NVLAP for HUD building product certification requirements. }\end{array}$ & & HUD & 24 CFR 200.935(d)(3) \\
\hline Traceability & $\begin{array}{l}\text { This regulation requires that as part of laboratory qualifications applicable to all } \\
\text { testing laboratories participating in the program including manufacturer's } \\
\text { laboratories and the administrator's own laboratories when designated in the } \\
\text { specific program, each laboratory shall, "Provide a description of the applicable } \\
\text { standards and calibration equipment being used and the calibration procedures } \\
\text { followed, including National Bureau of Standards traceability, when applicable. } \\
\text { List outside organizations providing calibration services, if used." }\end{array}$ & & HUD & 24 CFR 200.935(e)(2)(iii) \\
\hline CS $138-55$ & $\begin{array}{l}\text { Reference is made to NIST CS } 138-55 \text { "Insect Wire Screening" as a standard } \\
\text { that has been incorporated by reference in the HUD Minimum Property } \\
\text { Standards (MPS) in } 24 \text { CFR part } 200 .\end{array}$ & 1955 & HUD & 24 CFR 200, Appendix A \\
\hline
\end{tabular}




\begin{tabular}{|c|c|c|c|c|}
\hline CS 242-62 & $\begin{array}{l}\text { Reference is made to NIST CS } 242-62 \text { " } 13 / 4 \text { " Steel Doors \& Frames" as a } \\
\text { standard that has been incorporated by reference in the HUD Minimum } \\
\text { Property Standards (MPS) in } 24 \text { CFR part } 200 .\end{array}$ & 1962 & HUD & 24 CFR 200, Appendix A \\
\hline PS $1-83$ & $\begin{array}{l}\text { Reference is made to NIST PS 1-83 "Product Standard for Construction and } \\
\text { Industrial Plywood with Typical APA Trademarks" as a standard that has been } \\
\text { incorporated by reference in the HUD Minimum Property Standards (MPS) } \\
\text { in } 24 \text { CFR part } 200 .\end{array}$ & 1983 & HUD & 24 CFR 200, Appendix A \\
\hline PS 2-92 & $\begin{array}{l}\text { Reference is made to NIST PS 2-92 "Performance Standard for Wood-Based } \\
\text { Structural-Use Panels" as a standard that has been incorporated by reference in } \\
\text { the HUD Minimum Property Standards (MPS) in } 24 \text { CFR part } 200 \text {. }\end{array}$ & 1992 & HUD & 24 CFR 200, Appendix A \\
\hline DOC FF1-70 & $\begin{array}{l}\text { Standard test method for Flammability of Finished Textile Floor Covering } \\
\text { Materials - also available as ASTM D2859-76, incorporated by reference - } \\
\text { NBS standard has been stated under "Supplementary specific procedural } \\
\text { requirements under HUD building product standards and certification program } \\
\text { for carpet and carpet with attached cushion". (mandatory) }\end{array}$ & 1970 & HUD & 24 CFR 200.942 \\
\hline NVLAP Accreditation & $\begin{array}{l}\text { States that periodic testing for quality control will be conducted on "select } \\
\text { samples for testing, and testing shall be conducted, in accordance with the } \\
\text { applicable standards in a laboratory accredited by the National Voluntary } \\
\text { Laboratory Accreditation Program (NVLAP) of the National Bureau of } \\
\text { Standards, U.S. Department of Commerce" (mandatory) }\end{array}$ & & HUD & 24 CFR 200.942(c)(1) \\
\hline $\begin{array}{l}\text { Voluntary Public Standard 1- } \\
83\end{array}$ & $\begin{array}{l}\text { Construction and Industrial Plywood - States that " All plywood made to } \\
\text { specifications of Voluntary Product Standard, PS 1-83, "Construction and } \\
\text { Industrial Plywood" (published by the U.S. Department of Commerce, National } \\
\text { Bureau of Standards (May 1984)) and grade marked as PS 1-83 shall conform to } \\
\text { the requirements of PS 1-83, except that all veneers may be D-grade" as a } \\
\text { supplementary specific requirements under the HUD building product standards } \\
\text { and certification program for plywood and other performance rated wood-based } \\
\text { structural-use panels (mandatory). }\end{array}$ & & HUD & 24 CFR 200.944 \\
\hline $\begin{array}{l}\text { Voluntary Public Standard } \\
20-94\end{array}$ & $\begin{array}{l}\text { States that lumber shall be grademarked in compliance with VPS } 20-94 \\
\text { American Softwood Lumber Standard as a Supplementary specific requirements } \\
\text { under the HUD building product standards and certification program for the } \\
\text { grademarking of lumber. This VPS has been incorporated by reference. }\end{array}$ & 1994 & HUD & 24 CFR 200.943(a)(1) \\
\hline NVLAP Accreditation & $\begin{array}{l}\text { NVLAP - carpet -requires that "Every six months, three samples and one annual } \\
\text { field sample of carpet shall be submitted to the Administrator for testing in a } \\
\text { laboratory accredited by the National Voluntary Laboratory Accreditation } \\
\text { Program of the U.S. Department of Commerce" as part of a periodic testing and } \\
\text { quality assurance inspection protocol under Supplementary specific } \\
\text { requirements under the HUD building product standards and certification } \\
\text { program for carpet(mandatory). }\end{array}$ & & HUD & 24 CFR 200.945 \\
\hline
\end{tabular}




\begin{tabular}{|c|c|c|c|c|}
\hline $\begin{array}{l}\text { Voluntary Product Standard } \\
1-83\end{array}$ & $\begin{array}{l}\text { In specifying Body and Frame Construction Requirements under Manufactured } \\
\text { Home Construction and Safety Standards, this regulation refers to Voluntary } \\
\text { Product Standard, Construction and Industrial Plywood -PS-1-83 (standards for } \\
\text { wood and wood products). Materials meeting this standard when appropriate are } \\
\text { considered acceptable unless otherwise specified herein or unless substantial } \\
\text { doubt exists as to conformance. }\end{array}$ & & HUD & 24 CFR 3280.304(b)(1) \\
\hline Public Standard 2-92 & $\begin{array}{l}\text { In specifying Body and Frame Construction Requirements under Manufactured } \\
\text { Home Construction and Safety Standards, this regulation refers to Performance } \\
\text { Standard for Wood-Based Structural Use Panels-PS-2-92, APA. Materials } \\
\text { meeting this standard when appropriate are considered acceptable unless } \\
\text { otherwise specified herein or unless substantial doubt exists as to conformance. }\end{array}$ & & HUD & 24 CFR 3280.304 \\
\hline NBS weights and measures & $\begin{array}{l}\text { "b) All weights and measure shall conform to standards set by the National } \\
\text { Bureau of Standards and to standards, if any, set by the tribe and, if not in } \\
\text { conflict with tribal regulations, to the standards set by the State". Part of the } \\
\text { Health and Sanitation requirements for general business practices on certain } \\
\text { Indian reservations. }\end{array}$ & No date & Indian Affairs & 25CFR141.17 \\
\hline $\begin{array}{l}\text { NBS Publication - computer } \\
\text { security }\end{array}$ & $\begin{array}{l}\text { "(c) When maintained in computerized form, student records shall be } \\
\text { maintained, at a minimum, subject to safeguards based on those recommended } \\
\text { in the National Bureau of Standards' booklet, "Computer Security Guidelines for } \\
\text { Implementing the Privacy Act of 1974" (May 30, 1975), and any supplements to } \\
\text { it, which are adequate and appropriate to assure the integrity of records in the } \\
\text { system." }\end{array}$ & 1974 & Indian Affairs & 25 CFR 43.22 \\
\hline $\begin{array}{l}\text { NBS Publication - computer } \\
\text { security }\end{array}$ & $\begin{array}{l}\text { "(c) Records maintained in computerized form. When maintained in } \\
\text { computerized form, records subject to the Privacy Act shall be maintained, at a } \\
\text { minimum, subject to safeguards based on those recommended in the National } \\
\text { Bureau of Standards booklet "Computer Security Guidelines for Implementing } \\
\text { the Privacy Act of 1974" (May 30, 1975), and any supplements thereto, which } \\
\text { are adequate and appropriate to assuring the integrity of records in the system." }\end{array}$ & 1974 & Indian Affairs & 25CFR 700.263 \\
\hline NBS Security Guidelines & $\begin{array}{l}\text { "(a) The Office Administrator or Security Officer shall be responsible for issuing } \\
\text { regulations governing the security of systems of records. To the extent that such } \\
\text { regulations govern the security of automated systems of records, the regulations } \\
\text { shall be consistent with the guidelines developed by the National Bureau of } \\
\text { Standards." }\end{array}$ & No date & $\begin{array}{l}\text { Judicial } \\
\text { Administration }\end{array}$ & 28 CFR 700.24 \\
\hline
\end{tabular}




\begin{tabular}{|c|c|c|c|c|}
\hline CS 202-56 & $\begin{array}{l}\text { Industrial Lifts and Hinged Loading Ramps??? "(3) Powered dockboards shall } \\
\text { be designed and constructed in accordance with Commercial Standard CS202- } \\
56 \text { (1961) "Industrial Lifts and Hinged Loading Ramps published by the U.S. } \\
\text { Department of Commerce, which is incorporated by reference as specified in } \\
\text { §1910.6." }\end{array}$ & 1961 & DOL/OSHA & 29 CFR 1910.30 \\
\hline NBS coupler & $\begin{array}{l}\text { "Appendix E to \$1910.95-Acoustic Calibration of Audiometers. This Appendix } \\
\text { is Mandatory. Audiometer calibration shall be checked acoustically, at least } \\
\text { annually, according to the procedures described in this appendix. The } \\
\text { equipment necessary to perform these measurements is a sound level meter, } \\
\text { octave-band filter set, and a National Bureau of Standards 9A coupler. In } \\
\text { making these measurements, the accuracy of the calibrating equipment shall be } \\
\text { sufficient to determine that the audiometer is within the tolerances permitted by } \\
\text { American Standard Specification for Audiometers, S3.6-1969." }\end{array}$ & No date & DOL/OSHA & 29 CFR 1910.95 \\
\hline Reference publications & 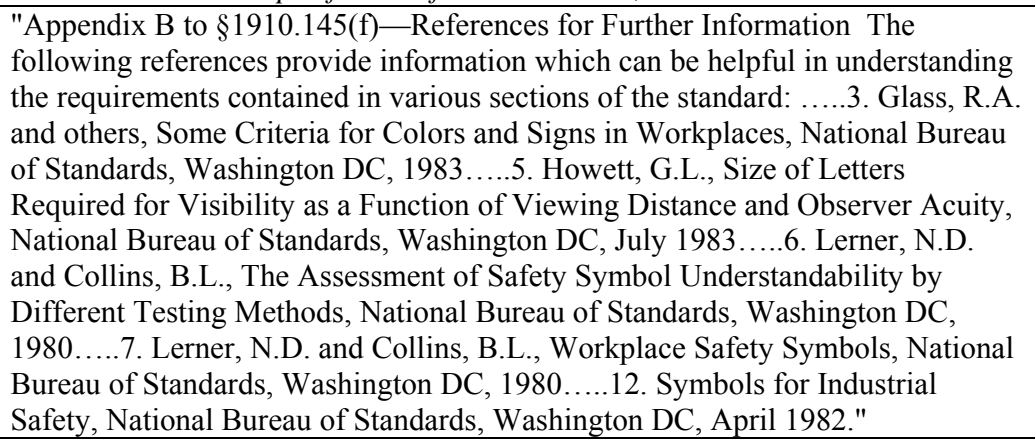 & $\begin{array}{l}1980- \\
1983\end{array}$ & DOL/OSHA & 29 CFR 1910.145 \\
\hline NVLAP & $\begin{array}{l}\text { Asbestos -- B) Performing tests of the material containing PACM which } \\
\text { demonstrate that no ACM is present in the material..... Analysis of samples shall } \\
\text { be performed by persons or laboratories with proficiency demonstrated by } \\
\text { current successful participation in a nationally recognized testing program such } \\
\text { as the National Voluntary Laboratory Accreditation Program (NVLAP) or the } \\
\text { National Institute for Standards and Technology (NIST) or the Round Robin for } \\
\text { bulk samples administered by the American Industrial Hygiene Association } \\
\text { (AIHA) or an equivalent nationally-recognized round robin testing program. }\end{array}$ & & DOL/OSHA & 29 CFR 1910.1001 \\
\hline Publication & $\begin{array}{l}\text { I. Appendix general references. The following references provide information } \\
\text { which can be helpful in understanding the requirements contained in all of the } \\
\text { sections of subpart L:J. Employee alarm systems: ... 8. Fire Alarm and } \\
\text { Communication Systems. National Bureau of Standards. Washington, D.C., } \\
\text { April 1978. }\end{array}$ & 1978 & DOL/OSHA & $\begin{array}{l}\text { 1910.165 Appendix C to } \\
\text { Subpart L }\end{array}$ \\
\hline
\end{tabular}




\begin{tabular}{|c|c|c|c|c|}
\hline SRM 2670 & $\begin{array}{l}\text { Refers to SRM } 2670 \text { as a source of reference materials that maybe available for } \\
\text { use in QC/QA analyses of Cadmium in Urine under the Occupational Safety and } \\
\text { Health Standards for Hazardous and Toxic Materials. The reference reads } \\
\text { "National Institute of Standards and Technology (NIST), Dept. of Commerce, } \\
\text { Gaithersburg, MD; tel: (301) 975-6776. (Prepared as SRM } 2670 \text { freeze-dried } \\
\text { urine [metals]; set includes normal and elevated levels of metals; cadmium is } \\
\text { certified for elevated level of } 88.0 \mu \mathrm{g} / 1 \text { in reconstituted urine.)". }\end{array}$ & & DOL/OSHA & $\begin{array}{l}\text { 29 CFR } 1910.1027 \\
3.3 .1 .1\end{array}$ \\
\hline Calibration & $\begin{array}{l}\text { Regulations defining the exemptions to the general duties of persons accredited } \\
\text { to certificate (sic) vessels' cargo gear refer to traceability to NBS as } \\
\text { "Dynamometers or other recording test equipment owned by an accredited } \\
\text { person shall have been tested for accuracy within the six months next preceding } \\
\text { application for accreditation or renewal of same. Such test shall be performed } \\
\text { with calibrating equipment which has been checked in turn so that indications } \\
\text { are traceable to the National Bureau of Standards." }\end{array}$ & & DOL/OSHA & 29 CFR 1919.10(d) \\
\hline Traceability/Calibration & $\begin{array}{l}\text { Regulations defining the exemptions to the general duties of persons accredited } \\
\text { to certificate (sic) shore-based material handling devices refer to traceability to } \\
\text { NBS as "All required unit proof load tests shall be carried out by the use of } \\
\text { weights as a dead load. Only where this is not possible may dynamometers or } \\
\text { other recording test equipment be used. Any such recording test equipment } \\
\text { owned by an accredited person shall have been tested for accuracy within the } 6 \\
\text { months next preceding application for accreditation or renewal thereof. Such test } \\
\text { shall be performed with calibrating equipment which has been checked in turn } \\
\text { so that indications are traceable to the National Bureau of Standards" }\end{array}$ & & DOL/OSHA & 29 CFR 1919.60(c) \\
\hline NBS Special Pub & $\begin{array}{l}\text { Ross, M. The Asbestos Minerals: Definitions, Description, Modes of } \\
\text { Formation, Physical and Chemical Properties and Health Risk to the } \\
\text { Mining Community, Nation Bureau of Standards Special Publication, } \\
\text { Washington, DC, 1977, is referred to in the description of the method } \\
\text { performance of the Polarized Light Microscopy of Asbestos (Non- } \\
\text { Mandatory) under the safety and health regulations for construction. }\end{array}$ & 1977 & DOL/OSHA & $\begin{array}{l}\text { 29 CFR } 1926.1101 \\
\text { Appendix K } 5.9\end{array}$ \\
\hline Proficiency Testing & $\begin{array}{l}\text { Reference is made to NIST having conducted proficiency testing of laboratories } \\
\text { on a national scale for method performance of the Polarized Light Microscopy } \\
\text { of Asbestos (Non-Mandatory) under the safety and health regulations for } \\
\text { construction. }\end{array}$ & & DOL/OSHA & $\begin{array}{l}29 \text { CFR } 1926.1101 \\
\text { Appendix K 1.4.1 }\end{array}$ \\
\hline NBS Report BSS-121 & $\begin{array}{l}\text { Reference is made to NBS Report BSS-121 as a source of definitions, in part, } \\
\text { related to classifying soil and rock deposits based on site and environmental } \\
\text { conditions, and on the structure and composition of the earth deposits. This } \\
\text { relates to regulations under the safety and health regulations for construction. }\end{array}$ & & DOL/OSHA & $\begin{array}{l}29 \text { CFR } 1926 \text { Appendix } \\
\text { A(b) }\end{array}$ \\
\hline
\end{tabular}




\begin{tabular}{|c|c|c|c|c|}
\hline NBS report & $\begin{array}{l}\text { Reference is made to National Bureau of Standards (NBS) report, } \\
\text { "Recommended Technical Provisions for Construction Practice in Shoring and } \\
\text { Sloping of Trenches and Excavations" for defining the dimensions of timber } \\
\text { members in the section on the basis and limitations of data that can be used in } \\
\text { timber shoring as a method of preventing cave-ins in trenches that do not exceed } \\
\text { 20ft. in depth. This part is under the safety and health regulations for } \\
\text { construction. }\end{array}$ & & DOL/OSHA & $\begin{array}{l}29 \text { CFR } 1926 \text { Appendix C } \\
\text { (d)(1)(i) }\end{array}$ \\
\hline Laboratory accreditation & $\begin{array}{l}\text { This regulation requires that for performing tests of the material containing } \\
\text { PACM (Presumed Asbestos Containing Material) which demonstrate that no } \\
\text { ACM (asbestos containing material) is present in the material "Analysis of } \\
\text { samples shall be performed by persons or laboratories with proficiency } \\
\text { demonstrated by current successful participation in a nationally recognized } \\
\text { testing program such as the National Voluntary Laboratory Accreditation } \\
\text { Program (NVLAP) or the National Institute for Standards and Technology } \\
\text { (NIST) or the Round Robin for bulk samples administered by the American } \\
\text { Industrial Hygiene Association (AIHA) or an equivalent nationally-recognized } \\
\text { round robin testing program" for testing related to asbestos exposure. }\end{array}$ & & DOL/OSHA & $\begin{array}{l}29 \text { CFR } \\
1926.1101(j)(5)(\mathrm{ii})(\mathrm{B})\end{array}$ \\
\hline Handbook 69 & $\begin{array}{l}\text { Reference is made to "National Bureau of Standards Handbook No. } 69 \text { entitled } \\
\text { "Maximum Permissible Body Burdens and Maximum Permissible } \\
\text { Concentrations of Radionuclides in Air and in Water for Occupational } \\
\text { Exposure," issued June 5, 1959" to define the conditions which occupations } \\
\text { involving exposure to radioactive substances and to ionizing radiations are } \\
\text { considered particularly hazardous and detrimental to health for minors between } \\
16 \text { and } 18 \text { years of age, as part of the child labor regulations, orders and } \\
\text { statements of interpretation. }\end{array}$ & & DOL/WHD & 29 CFR 570.57(a)(1) \\
\hline NBS Handbook 81 & $\begin{array}{l}\text { This regulation states that "Guy wires of poles supporting high-voltage } \\
\text { transmission lines shall meet the requirements for grounding or insulator } \\
\text { protection of the National Electrical Safety Code, part 2, entitled "Safety Rules } \\
\text { for the Installation and Maintenance of Electric Supply and Communication } \\
\text { Lines" (also referred to as National Bureau of Standards Handbook } 81 \text {, } \\
\text { November 1, 1961) and Supplement } 2 \text { thereof issued March 1968, which are } \\
\text { hereby incorporated by reference and made a part hereof" as part of the safety } \\
\text { and health standards for surface metal and non-metal mines. }\end{array}$ & 1961 & DOL/MSHA & 30 CFR 56.12047 \\
\hline NBS Handbook 81 & $\begin{array}{l}\text { This regulation states that "Guy wires of poles supporting high-voltage } \\
\text { transmission lines shall meet the requirements for grounding or insulator } \\
\text { protection of the National Electrical Safety Code, part 2, entitled "Safety Rules } \\
\text { for the Installation and Maintenance of Electric Supply and Communication } \\
\text { Lines" (also referred to as National Bureau of Standards Handbook 81, Nov. 1, } \\
\text { 1961), and Supplement } 2 \text { thereof issued March 1968, which are hereby } \\
\text { incorporated by reference and made a part hereof" as part of the safety and } \\
\text { health standards for underground metal and non-metal mines. }\end{array}$ & 1961 & DOL/MSHA & 30 CFR 57.12047 \\
\hline
\end{tabular}




\begin{tabular}{|c|c|c|c|c|}
\hline Traceability/Calibration & $\begin{array}{l}\text { As part of the product testing requirements for testing by third party of the } \\
\text { applicants, this regulation states that "Unless otherwise specified in the subpart, } \\
\text { test instruments shall be calibrated at least as frequently as, and according to, the } \\
\text { instrument manufacturer's specifications, using calibration standards traceable to } \\
\text { those set by the National Bureau of Standards, U.S. Department of Commerce or } \\
\text { other nationally recognized standards and accurate to at least one significant } \\
\text { figure beyond the desired accuracy" }\end{array}$ & & DOL/MSHA & 30 CFR 7.4(b) \\
\hline Traceability/Calibration & $\begin{array}{l}\text { As part of the QA requirements for testing by third party or applicants, this } \\
\text { regulation states that "Unless otherwise specified in the subparts, calibrate } \\
\text { instruments used for the inspection and testing of critical characteristics at least } \\
\text { as frequently as, and according to, the instrument manufacturer's specifications, } \\
\text { using calibration standards traceable to those set by the National Bureau of } \\
\text { Standards, U.S. Department of Commerce or other nationally recognized } \\
\text { standards and use instruments accurate to at least one significant figure beyond } \\
\text { the desired accuracy" }\end{array}$ & & DOL/MSHA & 30 CFR 7.7(b) \\
\hline Traceability & $\begin{array}{l}\text { This regulation requires that "Calibration gas values shall be traceable to the } \\
\text { National Institute for Standards and Testing (NIST), "Standard Reference } \\
\text { Materials" (SRMs). The analytical accuracy of the calibration gas values shall be } \\
\text { within } 2.0 \text { percent of NIST gas standards" as part of the test equipment } \\
\text { requirements for diesel engines intended for use in underground coal } \\
\text { mines(MANDATORY). }\end{array}$ & & DOL/MSHA & 30 CFR 7.86(b)(16) \\
\hline Traceability & $\begin{array}{l}\text { This regulation states that "Span gas values shall be traceable to NIST SRMs. } \\
\text { The analytical accuracy of the span gas values shall be within } 2.0 \text { percent of } \\
\text { NIST gas standards" as part of the test equipment requirements for diesel } \\
\text { engines intended for use in underground coal mines (MANDATORY). }\end{array}$ & & DOL/MSHA & 30 CFR 7.86(b)(17) \\
\hline Calibration & $\begin{array}{l}\text { States that "Light measuring instruments shall be properly calibrated and } \\
\text { maintained. Instruments shall be calibrated against standards traceable to the } \\
\text { National Bureau of Standards and color corrected to the Commission } \\
\text { Internationale de l'Eclairage (CIE) Spectral Luminous Curve" as a requirement } \\
\text { for procedures to be followed in measuring luminous intensity } \\
\text { (MANDATORY). }\end{array}$ & & DOL/MSHA & 30 CFR 75.1719-3 \\
\hline $\begin{array}{l}\text { National Electrical Safety } \\
\text { Code (NBS Handbook } 81 ?)\end{array}$ & $\begin{array}{l}\text { Reference is made to the National Electrical Safety Code as "High-voltage } \\
\text { powerlines located above driveways, haulageways, and railroad tracks shall be } \\
\text { installed to provide the minimum vertical clearance specified in National } \\
\text { Electrical Safety Code: Provided, however, That in no event shall any high- } \\
\text { voltage powerline be installed less than } 15 \text { feet above ground". The National } \\
\text { Electrical Safety Code is the NBS Handbook } 81 \text {. }\end{array}$ & 1971 & DOL/MSHA & 30 CFR 77.807-1 \\
\hline
\end{tabular}




\begin{tabular}{|c|c|c|c|}
\hline Security standards & $\begin{array}{l}\text { This regulation states that "Automated systems shall comply with the security } \\
\text { standards promulgated by the National Bureau of Standards" to meet the } \\
\text { requirements of accurate and secure maintenance of records under the Privacy } \\
\text { Act. }\end{array}$ & Treasury & 31 CFR $1.22(\mathrm{~d})(3)(\mathrm{i})$ \\
\hline Handbook 69 & $\begin{array}{l}\text { This regulation states that "All new activities and modification of existing } \\
\text { facilities which involve the continuous release of radioactive materials in } \\
\text { effluents to air, water or sanitary sewerage systems will not exceed } 1 \text { percent of } \\
\text { the activity concentration as specified in National Council on Radiation } \\
\text { Protection and Measurement Report No. } 22 \text { (National Bureau of Standards } \\
\text { Handbook No. 69) and } 10 \text { CFR part } 20 \text { when averaged over } 1 \text { month..." as part } \\
\text { of policies and procedures applicable to radioactive materials and nuclear } \\
\text { accidents and incidents. }\end{array}$ & DOD & 32 CFR 650.139(h)(i) \\
\hline Measurement & $\begin{array}{l}\text { Requires that "Engine flywheel torque readout must meet one of the two } \\
\text { following standards for accuracy" both of which refer to the NIST true value, to } \\
\text { meet the stated dynamometer and engine equipment } \\
\text { specifications(MANDTORY). }\end{array}$ & EPA & 40 CFR 1065.105(a)(2) \\
\hline Traceability & $\begin{array}{l}\text { Requires that "Flow meters must have accuracy and precision of } \pm 2 \text { percent of } \\
\text { point or better and be traceable to NIST standards" as part of the requirements } \\
\text { for equipment and analyzers. }\end{array}$ & EPA & 40 CFR 1065.150(a) \\
\hline Traceability & $\begin{array}{l}\text { For meeting the requirements that analytical gases have to comply with for } \\
\text { accuracy and purity specifications the regulation states that "The calibration } \\
\text { gases in paragraph (c)(1) of this section must be traceable to within one percent } \\
\text { of NIST gas standards or other gas standards we have approved. Span gases in } \\
\text { paragraph (c)(1) of this section must be accurate to within two percent of true } \\
\text { concentration, where true concentration refers to NIST gas standards, or other } \\
\text { gas standards we have approved." }\end{array}$ & EPA & 40 CFR $1065.250(\mathrm{c})(2)$ \\
\hline Traceability & $\begin{array}{l}\text { States that gases other that those specifically stated can be used provided that } \\
\text { they meet the requirements that "they are traceable to within } \pm 2 \text { percent of NIST } \\
\text { gas standards or other standards we have approved" as part of the requirements } \\
\text { that analytical gases have to comply with to meet accuracy and purity } \\
\text { specifications. }\end{array}$ & EPA & 40 CFR $1065.250(\mathrm{c})(3)(\mathrm{i})$ \\
\hline Traceability & $\begin{array}{l}\text { Requires a knowledge of "the concentration of primary gases used for blending } \\
\text { to an accuracy of at least } \pm 1 \text { percent, traceable to NIST gas standards or other } \\
\text { gas standards we have approved" for purposes of "generate calibration and span } \\
\text { gases using precision blending devices (gas dividers) to dilute gases with } \\
\text { purified nitrogen or with purified synthetic air" as part of the requirements that } \\
\text { analytical gases have to comply with to meet accuracy and purity specifications. }\end{array}$ & EPA & 40 CFR $1065.250(\mathrm{c})(4)$ \\
\hline Traceability & $\begin{array}{l}\text { Exempts the need for approval to be sought for using international calibration } \\
\text { standards, if the "standards that have been shown to be traceable to NIST } \\
\text { standards". This applies to analyzer and equipment calibration and is stated as } \\
\text { part of the test procedures and equipment requirements. }\end{array}$ & EPA & 40 CFR 1065.305(b) \\
\hline
\end{tabular}




\begin{tabular}{|c|c|c|c|c|}
\hline Traceability & $\begin{array}{l}\text { For purposes of torque calibration "the NIST "true value" torque is defined as } \\
\text { the torque calculated by taking the product of an NIST traceable weight or force } \\
\text { and a sufficiently accurate horizontal distance along a lever arm, corrected for } \\
\text { the lever arm's hanging torque". }\end{array}$ & & EPA & 40 CFR 1065.315 \\
\hline Traceability & $\begin{array}{l}\text { Calibration weights used for calibration of torque-measuring devices have to be } \\
\text { traceable to NIST weights. }\end{array}$ & & EPA & $\begin{array}{l}40 \text { CFR } 1065.315(a)(1) \\
(b)(1)\end{array}$ \\
\hline Measurement & $\begin{array}{l}\text { Defines the term "accuracy" to mean "the maximum difference between a } \\
\text { measured or calculated value and the true value, where the true value is } \\
\text { determined by NIST". }\end{array}$ & & & 40 CFR 1065.1001 \\
\hline Traceability & $\begin{array}{l}\text { A stock solution is defined as "A solution containing an analyte that is prepared } \\
\text { using a reference material traceable to EPA, the National Institute of Science } \\
\text { and Technology (NIST), or a source that will attest to the purity and authenticity } \\
\text { of the reference material" as part of the definitions pertaining to Method 1613, } \\
\text { Revision B for the determination of Tetra- Through Octa-Chlorinated Dioxins } \\
\text { and Furans by Isotope Dilution HRGC/HRMS as one of the Methods for } \\
\text { Organic Chemical Analysis of Municipal and Industrial Wastewater. }\end{array}$ & & EPA & $\begin{array}{l}40 \text { CFR } 136 \text { Appendix A; } \\
\text { Method 1613, Rev.B } 24.2\end{array}$ \\
\hline NBS SP 442 & $\begin{array}{l}\text { NBS SP } 442 \text { "Giam, C.S., and Chan, H.S. "Control of Blanks in the Analysis of } \\
\text { Phthalates in Air and Ocean Biota Samples," U.S. National Bureau of Standards, } \\
\text { Special Publication 442, pp. 701-708, 1976" is referred to in specifying Method } \\
608 \text { which is applicable for determination of certain organochlorines and PCBs } \\
\text { as one of the Methods for Organic Chemical Analysis of Municipal and } \\
\text { Industrial Wastewater }\end{array}$ & 1976 & EPA & $\begin{array}{l}40 \text { CFR } 136 \text { Appendix A } \\
\text { Method } 608\end{array}$ \\
\hline NBS SP 442 & $\begin{array}{l}\text { NBS SP } 442 \text { "Giam, C.S., and Chan, H.S. "Control of Blanks in the Analysis of } \\
\text { Phthalates in Air and Ocean Biota Samples," U.S. National Bureau of Standards, } \\
\text { Special Publication 442, pp. 701-708, 1976" is referred to in specifying Method } \\
606 \text { which is applicable for determination of certain phthalate esters as one of } \\
\text { the Methods for Organic Chemical Analysis of Municipal and Industrial } \\
\text { Wastewater }\end{array}$ & 1976 & EPA & $\begin{array}{l}\text { 40 CFR } 136 \text { Appendix A } \\
\text { Method } 606\end{array}$ \\
\hline NBS Handbook 69 & $\begin{array}{l}\text { Reference to NBS Handbook 69, in defining "Man-made beta particle and } \\
\text { photon emitters" as all radionuclides emitting beta particles and/or photons listed } \\
\text { in Maximum Permissible Body Burdens and Maximum Permissible } \\
\text { Concentration of Radionuclides in Air or Water for Occupational Exposure, } \\
\text { NBS Handbook 69, except the daughter products of thorium-232, uranium-235 } \\
\text { and uranium-238, as part of the definitions under the National Primary Drinking } \\
\text { Water Regulations. }\end{array}$ & 1963 & EPA & 40 CFR 141.2 \\
\hline
\end{tabular}




\begin{tabular}{|c|c|c|c|c|}
\hline NBS Handbook 69 & $\begin{array}{l}\text { Reference is made to the NBS Handbook } 69 \text { to state that "Except for the } \\
\text { radionuclides listed in table A, the concentration of man-made radionuclides } \\
\text { causing } 4 \text { mrem total body or organ dose equivalents must be calculated on the } \\
\text { basis of } 2 \text { liter per day drinking water intake using the } 168 \text { hour data list in } \\
\text { "Maximum Permissible Body Burdens and Maximum Permissible } \\
\text { Concentrations of Radionuclides in Air and in Water for Occupational } \\
\text { Exposure," NBS (National Bureau of Standards) Handbook } 69 \text { as amended } \\
\text { August 1963, U.S. Department of Commerce" (MANDATORY) incorporated } \\
\text { by reference }\end{array}$ & 1963 & EPA & 40 CFR 141.66(d)(2) \\
\hline Traceability & $\begin{array}{l}\text { Method 1650-Adsorbable Organic Halides by Adsorption and Coulometric } \\
\text { Titration, and Method } 1653 \text { - Chlorinated Phenolics in Wastewater by In Situ } \\
\text { Acetylation and GCMS define stock solution as "a solution containing an } \\
\text { analyte that is prepared using a reference material traceable to EPA, the National } \\
\text { Institute of Science and Technology (NIST), or a source that will attest to the } \\
\text { purity and authenticity of the reference material". }\end{array}$ & & EPA & $\begin{array}{l}40 \text { CFR } 430 \text { Appendix A, } \\
\text { Method } 1650,18.2 \\
\text { Method } 1653,20.2\end{array}$ \\
\hline $\begin{array}{l}\text { EPA/NIST Mass Spec } \\
\text { Library }\end{array}$ & $\begin{array}{l}\text { It is advised that the most recent version of the EPA/NIST Mass Spectral } \\
\text { Library be available, to be used as part of the data system where the computer } \\
\text { system has to be interfaced to the mass spec and the "system must allow the } \\
\text { continuous acquisition and storage on machine-readable media of all mass } \\
\text { spectra obtained throughout the duration of the chromatographic program". This } \\
\text { forms part of the procedures for Determination of Crude Oil Contamination in } \\
\text { Non-Aqueous Drilling Fluids by Gas Chromatography/Mass Spectrometry } \\
\text { (GC/MS). }\end{array}$ & & EPA & $\begin{array}{l}\text { 40 CFR 435 Appendix 5; } \\
6.3 .4\end{array}$ \\
\hline SRM 1582 & $\begin{array}{l}\text { NIST SRM } 1582 \text { petroleum crude oil is stated as the Standard crude oil for } \\
\text { Reverse Phase Extraction (RPE) Method for Detection of Oil Contamination in } \\
\text { Non-Aqueous Drilling Fluids (NAF), under the regulations in the oil and gas } \\
\text { extraction point source category. }\end{array}$ & & EPA & $\begin{array}{l}\text { 40 CFR } 435 \text { Appendix 6; } \\
7.3\end{array}$ \\
\hline SRM & $\begin{array}{l}\text { Definitions -defines "traceable" as a local standard has been compared and } \\
\text { certified either directly or via not more than one intermediate standard, to a } \\
\text { primary standard such as a National Bureau of Standards Standard Reference } \\
\text { Material (NBS SRM), or a USEPA/NBS-approved Certified Reference Material } \\
\text { (CRM) - and hence references NBS SRMs }\end{array}$ & & EPA & 40 CFR 50.1 \\
\hline NBS Calibration & $\begin{array}{l}\text { As part of the calibration procedures for flow measurements defined under the } \\
\text { Reference Method for the Determination of Sulfur Dioxide in the Atmosphere } \\
\text { (Pararosaniline Method) it is required that "Flow measuring devices used for the } \\
\text { on-site flow measurements required in } 9.4 .2 \text { must be calibrated against a reliable } \\
\text { flow or volume standard such as an NBS traceable bubble flowmeter or } \\
\text { calibrated wet test meter". }\end{array}$ & & EPA & $\begin{array}{l}\text { 40 CFR } 50 \text { Appendix A } \\
9.4 .1\end{array}$ \\
\hline
\end{tabular}




\begin{tabular}{|c|c|c|c|}
\hline NBS SRM 1625 & $\begin{array}{l}\text { In the dynamic calibration procedures used as part of the Reference Method for } \\
\text { the Determination of Sulfur Dioxide in the Atmosphere (Pararosaniline Method), } \\
\text { under the National Primary and Secondary Ambient Air Quality Standards, } \\
\text { "Atmospheres containing accurately known concentrations of sulfur dioxide are } \\
\text { prepared using permeation devices. In the systems for generating these } \\
\text { atmospheres, the permeation device emits gaseous SO2 at a known, low, } \\
\text { constant rate, provided the temperature of the device is held constant }\left( \pm 0.1{ }^{\circ} \mathrm{C}\right) \\
\text { and the device has been accurately calibrated at the temperature of use. The SO2 } \\
\text { permeating from the device is carried by a low flow of dry carrier gas to a } \\
\text { mixing chamber where it is diluted with SO2-free air to the desired } \\
\text { concentration and supplied to a vented manifold." Further, "Permeation devices" } \\
\text { as described above "may be prepared or purchased and in both cases must be } \\
\text { traceable either to a National Bureau of Standards (NBS) Standard Reference } \\
\text { Material (SRM 1625, SRM 1626, SRM 1627) or to an NBS/EPA-approved } \\
\text { commercially available Certified Reference Material (CRM)." }\end{array}$ & EPA & $\begin{array}{l}40 \text { CFR } 50 \text { Appendix A } \\
10.3\end{array}$ \\
\hline NBS SRM 1626 & $\begin{array}{l}\text { In the dynamic calibration procedures used as part of the Reference Method for } \\
\text { the Determination of Sulfur Dioxide in the Atmosphere (Pararosaniline Method), } \\
\text { under the National Primary and Secondary Ambient Air Quality Standards, } \\
\text { "Atmospheres containing accurately known concentrations of sulfur dioxide are } \\
\text { prepared using permeation devices. In the systems for generating these } \\
\text { atmospheres, the permeation device emits gaseous SO2 at a known, low, } \\
\text { constant rate, provided the temperature of the device is held constant }\left( \pm 0.1{ }^{\circ} \mathrm{C}\right) \\
\text { and the device has been accurately calibrated at the temperature of use. The SO2 } \\
\text { permeating from the device is carried by a low flow of dry carrier gas to a } \\
\text { mixing chamber where it is diluted with SO2-free air to the desired } \\
\text { concentration and supplied to a vented manifold." Further, "Permeation devices" } \\
\text { as described above "may be prepared or purchased and in both cases must be } \\
\text { traceable either to a National Bureau of Standards (NBS) Standard Reference } \\
\text { Material (SRM 1625, SRM 1626, SRM 1627) or to an NBS/EPA-approved } \\
\text { commercially available Certified Reference Material (CRM)." }\end{array}$ & EPA & $\begin{array}{l}40 \text { CFR } 50 \text { Appendix A } \\
10.3\end{array}$ \\
\hline
\end{tabular}




\begin{tabular}{|c|c|c|c|}
\hline NBS SRM 1627 & $\begin{array}{l}\text { In the dynamic calibration procedures used as part of the Reference Method for } \\
\text { the Determination of Sulfur Dioxide in the Atmosphere (Pararosaniline Method), } \\
\text { under the National Primary and Secondary Ambient Air Quality Standards, } \\
\text { "Atmospheres containing accurately known concentrations of sulfur dioxide are } \\
\text { prepared using permeation devices. In the systems for generating these } \\
\text { atmospheres, the permeation device emits gaseous SO2 at a known, low, } \\
\text { constant rate, provided the temperature of the device is held constant }\left( \pm 0.1^{\circ} \mathrm{C}\right) \\
\text { and the device has been accurately calibrated at the temperature of use. The SO2 } \\
\text { permeating from the device is carried by a low flow of dry carrier gas to a } \\
\text { mixing chamber where it is diluted with SO2-free air to the desired } \\
\text { concentration and supplied to a vented manifold." Further, "Permeation devices" } \\
\text { as described above "may be prepared or purchased and in both cases must be } \\
\text { traceable either to a National Bureau of Standards (NBS) Standard Reference } \\
\text { Material (SRM 1625, SRM 1626, SRM 1627) or to an NBS/EPA-approved } \\
\text { commercially available Certified Reference Material (CRM)." }\end{array}$ & EPA & $\begin{array}{l}40 \text { CFR } 50 \text { Appendix A } \\
10.3\end{array}$ \\
\hline Traceability & $\begin{array}{l}\text { APPENDIX B -- REFERENCE METHOD FOR THE DETERMINTION OF } \\
\text { PARTICULATE MATTER IN THE ATMOSPHERE (NBS Traceable) - States } \\
\text { that equipment required for certifying a flow rate transfer standard includes a } \\
\text { positive displacement standard volume meter traceable to the National Bureau of } \\
\text { Standards }\end{array}$ & EPA & $\begin{array}{l}\text { 40 CFR 50 Appendix B; } \\
9.2 .1\end{array}$ \\
\hline NBS SRM traceable & $\begin{array}{l}\text { Requirements for reagents used in calibration procedures stated under } \\
\text { Measurement Principle and Calibration Procedure for the Measurement of } \\
\text { Carbon Monoxide in the Atmosphere (Non-Dispersive Infrared Photometry), } \\
\text { defined NATIONAL PRIMARY AND SECONDARY AMBIENT AIR } \\
\text { QUALITY STANDARDS under the national primary and secondary ambient } \\
\text { air quality standards, it is required that "Cylinder(s) of CO in air containing } \\
\text { appropriate concentrations(s) of CO suitable for the selected operating range of } \\
\text { the analyzer under calibration; CO standards for the dilution method may be } \\
\text { contained in a nitrogen matrix if the zero air dilution ratio is not less than 100:1. } \\
\text { The assay of the cylinder(s) must be traceable either to a National Bureau of } \\
\text { Standards (NBS) CO in air Standard Reference Material (SRM) or to an } \\
\text { NBS/EPA-approved commercially available Certified Reference Material } \\
\text { (CRM)." }\end{array}$ & EPA & $\begin{array}{l}40 \text { CFR } 50 \text { Appendix C } \\
3.1\end{array}$ \\
\hline Traceability & $\begin{array}{l}\text { APPENDIX D -- MEASUREMENT AND CALIBRATION PROCEDURE } \\
\text { FOR THE MEASUREMENT OF OZONE (NBS Traceable) - States that in } \\
\text { calibration of ozone analyzers, the flow rate through the O3 generator and the } \\
\text { dilution air flow rate (FD) be measured with a reliable flow or volume standard } \\
\text { traceable to NBS. }\end{array}$ & EPA & $\begin{array}{l}\text { 40 CFR 50 Appendix D; } \\
\text { 5.5.7 }\end{array}$ \\
\hline
\end{tabular}




\begin{tabular}{|c|c|c|c|}
\hline NBS SRM 1629 & $\begin{array}{l}\text { In stating the Measurement Principle and Calibration Procedure for the } \\
\text { Measurement of Nitrogen Dioxide in the Atmosphere (Gas Phase } \\
\text { Chemiluminescence), under the National Primary and Secondary Ambient Air } \\
\text { Quality Standards, for calibration using gas phase titration of an NO standard } \\
\text { with ozone, the NO concentration standard should be a "Gas cylinder standard } \\
\text { containing } 50 \text { to } 100 \text { ppm NO in N2 with less than } 1 \text { ppm NO2". Further, "This } \\
\text { standard must be traceable to a National Bureau of Standards (NBS) NO in N2 } \\
\text { Standard Reference Material (SRM } 1683 \text { or SRM 1684), an NBS NO2 Standard } \\
\text { Reference Material (SRM 1629), or an NBS/EPA-approved commercially } \\
\text { available Certified Reference Material (CRM) ". Similarly, for calibration using } \\
\text { NO2 permeation devices "Calibration standards are required for both NO and } \\
\text { NO2. The reference standard for the calibration may be either an NO or NO2 } \\
\text { standard, and must be traceable to a National Bureau of Standards (NBS) NO in } \\
\text { N2 Standard Reference Material (SRM 1683 or SRM 1684), and NBS NO2 } \\
\text { Standard Reference Material (SRM 1629), or an NBS/EPA-approved } \\
\text { commercially available Certified Reference Material (CRM)". }\end{array}$ & EPA & $\begin{array}{l}40 \text { CFR } 50 \text { Appendix F } \\
1.3 .1,2.3 .1\end{array}$ \\
\hline NBS SRM 1683 & $\begin{array}{l}\text { In stating the Measurement Principle and Calibration Procedure for the } \\
\text { Measurement of Nitrogen Dioxide in the Atmosphere (Gas Phase } \\
\text { Chemiluminescence), under the National Primary and Secondary Ambient Air } \\
\text { Quality Standards, for calibration using gas phase titration of an NO standard } \\
\text { with ozone, the NO concentration standard should be a "Gas cylinder standard } \\
\text { containing } 50 \text { to } 100 \text { ppm NO in N2 with less than } 1 \text { ppm NO2". Further, "This } \\
\text { standard must be traceable to a National Bureau of Standards (NBS) NO in N2 } \\
\text { Standard Reference Material (SRM } 1683 \text { or SRM 1684), an NBS NO2 Standard } \\
\text { Reference Material (SRM 1629), or an NBS/EPA-approved commercially } \\
\text { available Certified Reference Material (CRM) ". Similarly, for calibration using } \\
\text { NO2 permeation devices "Calibration standards are required for both NO and } \\
\text { NO2. The reference standard for the calibration may be either an NO or NO2 } \\
\text { standard, and must be traceable to a National Bureau of Standards (NBS) NO in } \\
\text { N2 Standard Reference Material (SRM 1683 or SRM 1684), and NBS NO2 } \\
\text { Standard Reference Material (SRM 1629), or an NBS/EPA-approved } \\
\text { commercially available Certified Reference Material (CRM)". }\end{array}$ & EPA & $\begin{array}{l}40 \text { CFR 50 Appendix F } \\
1.3 .1,2.3 .1\end{array}$ \\
\hline
\end{tabular}




\begin{tabular}{|c|c|c|c|}
\hline NBS SRM 1684 & $\begin{array}{l}\text { In stating the Measurement Principle and Calibration Procedure for the } \\
\text { Measurement of Nitrogen Dioxide in the Atmosphere (Gas Phase } \\
\text { Chemiluminescence), under the National Primary and Secondary Ambient Air } \\
\text { Quality Standards, for calibration using gas phase titration of an NO standard } \\
\text { with ozone, the NO concentration standard should be a "Gas cylinder standard } \\
\text { containing } 50 \text { to } 100 \text { ppm NO in N2 with less than } 1 \text { ppm NO2". Further, "This } \\
\text { standard must be traceable to a National Bureau of Standards (NBS) NO in N2 } \\
\text { Standard Reference Material (SRM } 1683 \text { or SRM 1684), an NBS NO2 Standard } \\
\text { Reference Material (SRM 1629), or an NBS/EPA-approved commercially } \\
\text { available Certified Reference Material (CRM) ". Similarly, for calibration using } \\
\text { NO2 permeation devices "Calibration standards are required for both NO and } \\
\text { NO2. The reference standard for the calibration may be either an NO or NO2 } \\
\text { standard, and must be traceable to a National Bureau of Standards (NBS) NO in } \\
\text { N2 Standard Reference Material (SRM 1683 or SRM 1684), and NBS NO2 } \\
\text { Standard Reference Material (SRM 1629), or an NBS/EPA-approved } \\
\text { commercially available Certified Reference Material (CRM)". }\end{array}$ & EPA & $\begin{array}{l}\text { 40 CFR 50 Appendix F } \\
1.3 .1,2.3 .1\end{array}$ \\
\hline Calibration /traceability & $\begin{array}{l}\text { The Reference Method for the Determination of Particulate Matter as PM10 in } \\
\text { the Atmosphere requires that "the flow rate transfer standard must be suitable for } \\
\text { the sampler's operating flow rate and must be calibrated against a primary flow } \\
\text { or volume standard that is traceable to the National Bureau of Standards (NBS)". } \\
\text { It is further required that a calibration relationship (e.g., an equation or family of } \\
\text { curves) be established such that traceability to the primary standard is accurate } \\
\text { to within } 2 \text { percent over the expected range of ambient conditions (i.e., } \\
\text { temperatures and pressures) under which the transfer standard will be used and } \\
\text { the transfer standard periodically recalibrated. }\end{array}$ & EPA & $\begin{array}{l}40 \text { CFR } 50 \text { Appendix J } \\
7.3,8.2 .2\end{array}$ \\
\hline Traceability & $\begin{array}{l}\text { APPENDIX L TO PART } 50 \text {-- REFERCNCE METHOD FOR THE } \\
\text { DETERMINATION OF FINE PARTICULATE MATTER (NIST Traceable) - } \\
\text { States that dimension of the impaction jets used in impactors must be verified by } \\
\text { the manufacturer using Class ZZ go/no-go plug gauges that are traceable to } \\
\text { NIST, and that standard used for calibrating or verifying the sampler's flow rate } \\
\text { measurement device have its own certification and be traceable to a National } \\
\text { Institute of Standards and Technology (NIST) primary standard for volume or } \\
\text { flow rate. }\end{array}$ & EPA & $\begin{array}{l}\text { 40 CFR } 50 \text { Appendix L; } \\
\text { 7.3.4.1; }\end{array}$ \\
\hline \multirow[t]{2}{*}{ Traceability } & $\begin{array}{l}\text { Requires that a flow rate standard used in the Reference Method for the } \\
\text { Determination of Fine Particulate Matter as PM2.5 in the Atmosphere must have } \\
\text { its own certification and be traceable to a National Institute of Standards and } \\
\text { Technology (NIST) primary standard for volume or flow rate. }\end{array}$ & & $\begin{array}{l}\text { 40 CFR 50 Appendix L; } \\
9.1 .2,9.2 .2\end{array}$ \\
\hline & $\begin{array}{l}\text { Appendix M to Part } 50 \text {-- Reference Method for the Determination of Particulate } \\
\text { Matter as PM10 in the Atmosphere - Requires calibration of flow rate transfer } \\
\text { standard against a primary flow or volume standard traceable to NIST }\end{array}$ & EPA & $\begin{array}{l}\text { 40 CFR 50 Appendix M; } \\
7.3 ; 8.2 .2\end{array}$ \\
\hline
\end{tabular}




\begin{tabular}{|c|c|c|c|}
\hline Traceability & $\begin{array}{l}\text { If using Method } 205 \text { "Verification of Gas Dilution Systems for Field Instrument } \\
\text { Calibrations" as a recommended test method for state implementation plans } \\
\text { under the requirements for preparation, adoption, and submittals of } \\
\text { implementation plans, the specifications for the method state that "The gas } \\
\text { dilution system shall be recalibrated once per calendar year using NIST- } \\
\text { traceable primary flow standards with an uncertainty } \leq 0.25 \text { percent." }\end{array}$ & EPA & $\begin{array}{l}40 \text { CFR } 51 \text { Appendix N; } \\
\text { Method 205; } 2.1 .1\end{array}$ \\
\hline Traceability & $\begin{array}{l}\text { Requires that "Span and zero gases should be traceable to National Bureau of } \\
\text { Standards reference gases whenever these reference gases are available" defined } \\
\text { as part of the minimum specifications of the calibration gases used to meet the } \\
\text { requirements of minimum requirements for continuous emission monitoring and } \\
\text { recording that each State Implementation Plan has to meet under the } \\
\text { requirements for preparation, adoption, and submittals of implementation plans. }\end{array}$ & EPA & $\begin{array}{l}\text { 40 CFR 51 Appendix P; } \\
3.3\end{array}$ \\
\hline Traceability & $\begin{array}{l}\text { Requires that in calibration of steady-state test equipment "the span gases used } \\
\text { for the gas calibration shall be traceable to National Institute of Standards and } \\
\text { Technology (NIST) standards } \pm 2 \% \ldots \text {.." This meets the inspection/maintenance } \\
\text { program requirements in both ozone and carbon monoxide (CO) nonattainment } \\
\text { areas, depending upon population and nonattainment classification or design } \\
\text { value. These are part of the requirements for preparation, adoption and submittal } \\
\text { of implementation plans. }\end{array}$ & EPA & $\begin{array}{l}40 \text { CFR } 51 \text { Subpart S, } \\
\text { Appendix A (d)(3) }\end{array}$ \\
\hline Traceability & $\begin{array}{l}\text { Requires that all calibration gases used in procedures for determining the } \\
\text { volatile organic compounds (VOC) content of captured gas stream shall be } \\
\text { traceable to NIST standards and shall be certified by the manufacturer to } \pm 1 \\
\text { percent of the tag value. The procedure is intended to be used as a segment in } \\
\text { the development of liquid/gas or gas/gas protocols for determining VOC capture } \\
\text { efficiency (CE) for surface coating and printing operations This procedure } \\
\text { pertains to testing for captured VOC emissions, part of the VOM measurement } \\
\text { techniques for capture efficiency and relates to the approval and promulgation of } \\
\text { implementation plans for Illinois. }\end{array}$ & EPA & $\begin{array}{c}40 \text { CFR } 52 \text { Subpart O, } \\
\text { Appendix B; G.1; } 2.1 .9\end{array}$ \\
\hline Traceability & $\begin{array}{l}\text { Requires that all calibration gases used in procedures for determining the } \\
\text { volatile organic compounds (VOC) content of captured gas streams shall be } \\
\text { traceable to NIST standards and shall be certified by the manufacturer to } \pm 1 \\
\text { percent of the tag value. The test is intended to be used as a segment in the } \\
\text { development of a gas/gas protocol in which fugitive emissions are measured for } \\
\text { determining VOC capture efficiency (CE) for surface coating and printing } \\
\text { operations. This procedure pertains to testing for captured VOC emissions } \\
\text { (dilution technique), part of the VOM measurement techniques for capture } \\
\text { efficiency and relates to the approval and promulgation of implementation plans } \\
\text { for Illinois. }\end{array}$ & EPA & $\begin{array}{l}40 \text { CFR } 52 \text { Subpart O, } \\
\text { Appendix B; G.2; 2.1.9 }\end{array}$ \\
\hline
\end{tabular}




\begin{tabular}{|c|c|c|c|}
\hline Traceability & $\begin{array}{l}\text { Requires that all calibration gases used in procedures for determining the } \\
\text { fugitive volatile organic compounds (VOC) emissions from a building enclosure } \\
\text { (BE) shall be traceable to NIST standards and shall be certified by the } \\
\text { manufacturer to } \pm 1 \text { percent of the tag value. The procedure is intended to be } \\
\text { used as a segment in the development of liquid/gas or gas/gas protocols for } \\
\text { determining VOC capture efficiency (CE) for surface coating and printing } \\
\text { operations. This procedure forms part of the VOM measurement techniques for } \\
\text { capture efficiency and relates to the approval and promulgation of } \\
\text { implementation plans for Illinois. }\end{array}$ & EPA & $\begin{array}{l}40 \text { CFR } 52 \text { Subpart O, } \\
\text { Appendix B; F.2; } 2.1 .9\end{array}$ \\
\hline Traceability & $\begin{array}{l}\text { Requires that all calibration gases used in procedures for determining the input } \\
\text { of volatile organic compounds (VOC) shall be traceable to NIST standards and } \\
\text { shall be certified by the manufacturer to } \pm 1 \text { percent of the tag value. The } \\
\text { procedure is intended to be used as a segment in the development of liquid/gas } \\
\text { protocols for determining VOC capture efficiency (CE) for surface coating and } \\
\text { printing operations. This procedure forms part of the VOM measurement } \\
\text { techniques for capture efficiency and relates to the approval and promulgation of } \\
\text { implementation plans for Illinois. }\end{array}$ & EPA & $\begin{array}{l}40 \text { CFR } 52 \text { Subpart O, } \\
\text { Appendix B; F.1; } 2.1 .9\end{array}$ \\
\hline Traceability & $\begin{array}{l}\text { Requires that all calibration gases used in procedures for determining the } \\
\text { fugitive volatile organic compounds (VOC) emissions from a temporary total } \\
\text { enclosure (TTE) shall be traceable to NIST standards and shall be certified by } \\
\text { the manufacturer to } \pm 1 \text { percent of the tag value. The procedure is intended to be } \\
\text { used as a segment in the development of liquid/gas or gas/gas protocols for } \\
\text { determining VOC capture efficiency (CE) for surface coating and printing } \\
\text { operations. This procedure forms part of the VOM measurement techniques for } \\
\text { capture efficiency and relates to the approval and promulgation of } \\
\text { implementation plans for Illinois. }\end{array}$ & EPA & $\begin{array}{l}40 \text { CFR 52 Subpart O, } \\
\text { Appendix B; L; 2.2.22 }\end{array}$ \\
\hline Traceability & $\begin{array}{l}\text { Requires that an applicant for a reference or equivalent method determination } \\
\text { for testing under the ambient air monitoring reference and equivalent methods } \\
\text { regulations "shall maintain and include records of all relevant measuring } \\
\text { equipment, including the make, type, and serial number or other identification, } \\
\text { and most recent calibration with identification of the measurement standard or } \\
\text { standards used and their National Institute of Standards and Technology (NIST) } \\
\text { traceability". The intent of these records is to demonstrate "the measurement } \\
\text { capability of each item of measuring equipment used for the application and } \\
\text { include a description and justification (if needed) of the measurement setup or } \\
\text { configuration in which it was used for the tests. The calibration results shall be } \\
\text { recorded and identified in sufficient detail so that the traceability of all } \\
\text { measurements can be determined and any measurement could be reproduced } \\
\text { under conditions close to the original conditions, if necessary, to resolve any } \\
\text { anomalies." }\end{array}$ & EPA & 40 CFR 53.4(b)(5)(i) \\
\hline
\end{tabular}




\begin{tabular}{|c|c|c|c|}
\hline NBS standards & $\begin{array}{l}\text { Requires the use of "NBS-certified standards whenever possible", for verifying } \\
\text { the concentrations of generated test atmospheres, (in particular Carbon dioxide, } \\
\text { methane, xylene) as part of the Procedures for Testing Performance } \\
\text { Characteristics of Automated Methods SO2, CO, O3, and NO2, under testing for } \\
\text { ambient air monitoring reference and equivalent methods. The regulations } \\
\text { further state that "if NBS standards are not available, obtain } 2 \text { standards from } \\
\text { independent sources which agree to within } 2 \text { percent; or obtain one standard and } \\
\text { submit it to an independent laboratory for analysis which must agree within } 2 \\
\text { percent of the supplier's nominal analysis". } \\
\text { Carbon dioxide, methane, xylene }\end{array}$ & EPA & 40 CFR 53.22 \\
\hline Traceability & $\begin{array}{l}\text { "The diameter of the jet of each impactor manufactured for a PM2.5 sampler } \\
\text { under the impactor design specifications set forth in } 40 \text { CFR part 50, appendix } \\
\text { L, shall be verified against the tolerance specified on the drawing, using } \\
\text { standard, NIST-traceable ZZ go/no go plug gages" to verify the PM2.5 jet } \\
\text { impactor diameter as part of the required specific tests to verify conformance to } \\
\text { critical component specifications to demonstrate compliance with design } \\
\text { specifications and manufacturing and test requirement, as part of the Procedures } \\
\text { for Testing Physical (Design) and Performance Characteristics of Reference } \\
\text { Methods and Class I Equivalent Methods for PM2.5 in ambient air monitoring } \\
\text { reference and equivalent methods (Mandatory). }\end{array}$ & EPA & 40 CFR 53.51(d)(1) \\
\hline Traceability & $\begin{array}{l}\text { Flow rate measurement device used as part of the required test equipment for } \\
\text { Leak check test, as part of the Procedures for Testing Physical (Design) and } \\
\text { Performance Characteristics of Reference Methods and Class I Equivalent } \\
\text { Methods for PM } 2.5 \text { in ambient air monitoring reference and equivalent methods } \\
\text { must have "a range } 70 \mathrm{~mL} / \mathrm{min} \text { to } 130 \mathrm{~mL} / \mathrm{min}, 2 \text { percent certified accuracy, } \\
\text { NIST-traceable" (mandatory). }\end{array}$ & EPA & 40 CFR 53.52(c)(1) \\
\hline \multirow[t]{2}{*}{ Traceability } & $\begin{array}{l}\text { Proof of traceability to NIST (if required) for all measurement instruments used } \\
\text { in testing for leak checks needs to be submitted. This testing constitutes part of } \\
\text { the Procedures for Testing Physical (Design) and Performance Characteristics of } \\
\text { Reference Methods and Class I Equivalent Methods for PM2.5" under the } \\
\text { ambient air monitoring reference and equivalent methods. }\end{array}$ & EPA & 40 CFR 53.52(d) \\
\hline & $\begin{array}{l}\text { Flow rate meters used as part of the required test equipment in testing for flow } \\
\text { rate accuracy, regulation, measurement accuracy, and cut-off as part of the } \\
\text { Procedures for Testing Physical (Design) and Performance Characteristics of } \\
\text { Reference Methods and Class I Equivalent Methods for PM } 2.5 \text { in ambient air } \\
\text { monitoring reference and equivalent methods must be "suitable for measuring } \\
\text { and recording the actual volumetric sample flow rate at the sampler downtube, } \\
\text { with a minimum range of } 10 \text { to } 25 \text { actual L/min, } 2 \text { percent certified, NIST- } \\
\text { traceable accuracy." (mandatory). }\end{array}$ & & 40 CFR 53.53(c)(1) \\
\hline
\end{tabular}




\begin{tabular}{|c|c|c|c|}
\hline Traceability & $\begin{array}{l}\text { Proof of traceability to NIST (if required) for all measurement instruments used } \\
\text { in testing for flow rate accuracy, regulation, measurement accuracy, and cut-off } \\
\text { needs to be submitted. This testing constitutes part of the Procedures for Testing } \\
\text { Physical (Design) and Performance Characteristics of Reference Methods and } \\
\text { Class I Equivalent Methods for PM2.5" under the ambient air monitoring } \\
\text { reference and equivalent methods. }\end{array}$ & EPA & 40 CFR 53.53(d) \\
\hline Traceability & $\begin{array}{l}\text { Flow rate meters used as part of the required test equipment in testing for proper } \\
\text { sampler operation following power interruptions as part of the Procedures for } \\
\text { Testing Physical (Design) and Performance Characteristics of Reference } \\
\text { Methods and Class I Equivalent Methods for PM } 2.5 \text { in ambient air monitoring } \\
\text { reference and equivalent methods must be "suitable for measuring and recording } \\
\text { the actual volumetric sample flow rate at the sampler downtube, with a } \\
\text { minimum range of } 10 \text { to } 25 \text { actual L/min, } 2 \text { percent certified, NIST-traceable } \\
\text { accuracy." (mandatory). }\end{array}$ & EPA & 40 CFR 53.54(b)(1) \\
\hline Traceability & $\begin{array}{l}\text { Proof of traceability to NIST (if required) for all measurement instruments used } \\
\text { in testing for proper sampler operation following power interruptions needs to be } \\
\text { submitted. This testing constitutes part of the Procedures for Testing Physical } \\
\text { (Design) and Performance Characteristics of Reference Methods and Class I } \\
\text { Equivalent Methods for PM2.5" under the ambient air monitoring reference and } \\
\text { equivalent methods. }\end{array}$ & EPA & 40 CFR 53.54(c) \\
\hline Traceability & $\begin{array}{l}\text { Flow rate meters used as part of the required test equipment in testing for the } \\
\text { effects of variations in power line voltage and ambient temperature as part of the } \\
\text { Procedures for Testing Physical (Design) and Performance Characteristics of } \\
\text { Reference Methods and Class I Equivalent Methods for PM } 2.5 \text { in ambient air } \\
\text { monitoring reference and equivalent methods must be "suitable for measuring } \\
\text { and recording the actual volumetric sample flow rate at the sampler downtube, } \\
\text { with a minimum range of } 10 \text { to } 25 \text { actual L/min, } 2 \text { percent certified, NIST- } \\
\text { traceable accuracy." (mandatory). }\end{array}$ & EPA & 40 CFR 53.55(c)(3) \\
\hline Traceability & $\begin{array}{l}\text { Proof of traceability to NIST (if required) for all measurement instruments used } \\
\text { in testing for the effects of variations in power line voltage ambient temperature } \\
\text { needs to be submitted. This testing constitutes part of the Procedures for Testing } \\
\text { Physical (Design) and Performance Characteristics of Reference Methods and } \\
\text { Class I Equivalent Methods for PM2.5" under the ambient air monitoring } \\
\text { reference and equivalent methods. }\end{array}$ & EPA & 40 CFR 53.55(d) \\
\hline Traceability & $\begin{array}{l}\text { Flow rate meters used as part of the required test equipment in testing for the } \\
\text { effects of variations in ambient pressure as part of the Procedures for Testing } \\
\text { Physical (Design) and Performance Characteristics of Reference Methods and } \\
\text { Class I Equivalent Methods for PM2.5 in ambient air monitoring reference and } \\
\text { equivalent methods must have "minimum range of } 10 \text { to } 25 \mathrm{~L} / \mathrm{min}, 2 \text { percent } \\
\text { certified, NIST-traceable accuracy" (mandatory). }\end{array}$ & EPA & 40 CFR 53.56(c)(2) \\
\hline
\end{tabular}




\begin{tabular}{|c|c|c|c|}
\hline Traceability & $\begin{array}{l}\text { Proof of traceability to NIST (if required) for all measurement instruments used } \\
\text { in testing for the effects of variations in ambient pressure needs to be submitted. } \\
\text { This testing constitutes part of the Procedures for Testing Physical (Design) and } \\
\text { Performance Characteristics of Reference Methods and Class I Equivalent } \\
\text { Methods for PM2.5" under the ambient air monitoring reference and equivalent } \\
\text { methods. }\end{array}$ & EPA & 40 CFR 53.56(d) \\
\hline Traceability & $\begin{array}{l}\text { NIST Traceable temperature sensors are part of the required test equipment for } \\
\text { use in tests "intended to measure a candidate sampler's ability to prevent } \\
\text { excessive overheating of the PM2.5 sample collection filter (or filters) under } \\
\text { conditions of elevated solar insolation..." This testing falls under the "Procedures } \\
\text { for Testing Physical (Design) and Performance Characteristics of Reference } \\
\text { Methods and Class I Equivalent Methods for PM2.5" as part of the ambient air } \\
\text { monitoring reference and equivalent methods. }\end{array}$ & EPA & 40 CFR 53.57(c)(4) \\
\hline Traceability & $\begin{array}{l}\text { Proof of traceability to NIST (if required) for all measurement instruments used } \\
\text { in the tests to measure a candidate sampler's ability to prevent excessive } \\
\text { overheating of the PM2.5 sample collection filter (or filters) under conditions of } \\
\text { elevated solar insolation needs to be submitted. This testing constitutes part of } \\
\text { the Procedures for Testing Physical (Design) and Performance Characteristics of } \\
\text { Reference Methods and Class I Equivalent Methods for PM2.5" under the } \\
\text { ambient air monitoring reference and equivalent methods. }\end{array}$ & EPA & 40 CFR 53.57(d) \\
\hline Traceability & $\begin{array}{l}\text { This regulation states that documentation is required "showing evidence of } \\
\text { appropriately recent calibration, certification of calibration accuracy, and NIST- } \\
\text { traceability (if required) of all measurement instruments used in the tests" } \\
\text { intended to verify adequate aerosol transport through any modified or air flow } \\
\text { splitting components that may be used in a Class I candidate equivalent method } \\
\text { sampler such as may be necessary to achieve sequential sampling capability. } \\
\text { This is stated as part of the Procedures for Testing Physical (Design) and } \\
\text { Performance Characteristics of Reference Methods and Class I Equivalent } \\
\text { Methods for PM2.5 under the Ambient Air Monitoring Reference and } \\
\text { Equivalent Methods. }\end{array}$ & EPA & 40 CFR 53.59(d) \\
\hline Traceability & $\begin{array}{l}\text { States that "All flow rate measurements used to calculate the test atmosphere } \\
\text { concentrations and the test results must be accurate to within } \pm 2 \text { percent, } \\
\text { referenced to a NIST-traceable primary standard"(MANDATORY). This } \\
\text { requirement is stated for sampler flow rate measurements in the test procedures } \\
\text { for a full wind tunnel test for Testing Performance Characteristics of Class II } \\
\text { Equivalent Methods for PM } 2.5 \text { under the Ambient Air Monitoring Reference } \\
\text { and Equivalent Methods. }\end{array}$ & EPA & 40 CFR 53.62(c)(8) \\
\hline
\end{tabular}




\begin{tabular}{|c|c|c|c|}
\hline Traceability & $\begin{array}{l}\text { Defines 'Traceable' to mean "a local standard has been compared and certified, } \\
\text { either directly or via not more than one intermediate standard, to a National } \\
\text { Institute of Standards and Technology (NIST)-certified primary standard such as } \\
\text { a NIST-Traceable Reference Material (NTRM) or a NIST-certified Gas } \\
\text { Manufacturer's Internal Standard (GMIS)." }\end{array}$ & EPA & 40 CFR 58.1 \\
\hline Traceability & $\begin{array}{l}\text { Requires that "gaseous pollutant concentration standards (permeation devices or } \\
\text { cylinders of compressed gas) used to obtain test concentrations for CO, SO2, } \\
\text { NO, and NO2 must be traceable to either a National Institute of Standards and } \\
\text { Technology (NIST) NIST-Traceable Reference Material (NTRM) or a NIST- } \\
\text { certified Gas Manufacturer's Internal Standard (GMIS)" as part of the quality } \\
\text { assurance requirements for state and local air monitoring station (SLAMS) for } \\
\text { Ambient Air Quality Surveillance. }\end{array}$ & EPA & $\begin{array}{l}\text { 40CFR 58 Appendix A } \\
\text { 2.1(f)2.3.1 }\end{array}$ \\
\hline Traceability & $\begin{array}{l}\text { States that "Gaseous standards (permeation tubes, permeation devices or } \\
\text { cylinders of compressed gas) used to obtain test concentrations for CO, SO2, } \\
\text { and NO2 must be traceable to either a National Institute of Standards and } \\
\text { Technology (NIST) gaseous Standard Reference Material (SRM) or an } \\
\text { NIST/EPA-approved commercially available Certified Reference Material } \\
\text { (CRM)." Further states that "direct use of a CRM as a working standard is } \\
\text { acceptable, but direct use of an NIST SRM as a working standard is discouraged } \\
\text { because of the limited supply and expense of SRMs". This requirement stated } \\
\text { under pollutant standards as part of the Quality Assurance Requirements for } \\
\text { Prevention of Significant Deterioration (PSD) Air Monitoring for Ambient Air } \\
\text { Quality Surveillance. }\end{array}$ & EPA & $\begin{array}{l}40 \text { CFR 58; Appendix B } \\
\text { 2.3.1 }\end{array}$ \\
\hline SRM & $\begin{array}{l}\text { States that "working and transfer standards and equipment used for auditing } \\
\text { must be different from the standards and equipment used for calibration and } \\
\text { spanning. The auditing standards and calibration standards may be referenced to } \\
\text { the same NIST, SRM, CRM, or primary UV photometer" as part of the } \\
\text { procedure to determine accuracy of automated methods under the data quality } \\
\text { assessment requirements for Prevention of Significant Deterioration (PSD) Air } \\
\text { Monitoring for Ambient Air Quality Surveillance. }\end{array}$ & EPA & $\begin{array}{l}40 \text { CFR 58; Appendix B } \\
3.2\end{array}$ \\
\hline Traceability & $\begin{array}{l}\text { Requires that the spectrophotometer used for attenuator calibration must have an } \\
\text { "accuracy of }<0.5 \% \text { transmittance, NIST traceable calibration" as a minimum } \\
\text { design specification (MANDATORY). This is stated as part of the performance } \\
\text { specifications for Standards of Performance for New Stationary Sources. }\end{array}$ & EPA & $\begin{array}{l}40 \text { CFR } 60 \text { Appendix B } \\
1.6 .3\end{array}$ \\
\hline Calibration & $\begin{array}{l}\text { States that an attenuator used to check the daily calibration drift and calibration } \\
\text { error of a COMS can be designated as a primary if calibrated by NIST. This is } \\
\text { stated as part of the performance specifications for Standards of Performance for } \\
\text { New Stationary Sources. }\end{array}$ & EPA & $\begin{array}{l}\text { 40 CFR } 60 \text { Appendix B } \\
\text { 1.7.1(1) }\end{array}$ \\
\hline
\end{tabular}




\begin{tabular}{|c|c|c|c|}
\hline SRM 930D & $\begin{array}{l}\text { States that an attenuator used to check the daily calibration drift and calibration } \\
\text { error of a COMS can be designated as a primary if calibrated on a 6-month } \\
\text { frequency through the assignment of a luminous transmittance value where the } \\
\text { spectrophotometer calibration has been verified through use of a NIST 930D } \\
\text { Standard Reference Material (SRM). This is stated as part of the performance } \\
\text { specifications for Standards of Performance for New Stationary Sources. }\end{array}$ & EPA & $\begin{array}{l}40 \text { CFR } 60 \text { Appendix B } \\
\text { 1.7.1(2)(i) }\end{array}$ \\
\hline SRM & $\begin{array}{l}\text { Requires "the use of cylinder gases that have been certified by comparison to } \\
\text { National Institute of Standards and Technology (NIST) gaseous standard } \\
\text { reference material (SRM) or NIST/EPA approved gas manufacturer's certified } \\
\text { reference material (CRM) following EPA Traceability Protocol Number 1", as } \\
\text { part of the specification for evaluating the acceptability of SO2 and NOX } \\
\text { continuous emission monitoring systems (CEMS) at the time of installation or } \\
\text { soon after and whenever specified in the regulations. This is stated as part of the } \\
\text { Specifications and Test Procedures for SO2 and NOX Continuous Emission } \\
\text { Monitoring Systems in Stationary Sources. }\end{array}$ & EPA & $\begin{array}{l}\text { 40 CFR } 60 \text { Appendix B } \\
2.16 .2 .4\end{array}$ \\
\hline Traceability & $\begin{array}{l}\text { This performance specification is applicable for measuring all hazardous air } \\
\text { pollutants (HAPs) which absorb in the infrared region and can be quantified } \\
\text { using Fourier Transform Infrared Spectroscopy (FTIR), as long as the } \\
\text { performance criteria of this performance specification are met. This specification } \\
\text { is to be used for evaluating FTIR continuous emission monitoring systems for } \\
\text { measuring HAPs regulated under Title III of the } 1990 \text { Clean Air Act } \\
\text { Amendments. This specification also applies to the use of FTIR CEMs for } \\
\text { measuring other volatile organic or inorganic species. As part of the } \\
\text { performance requirements this regulation states that the "audit sample can be a } \\
\text { mixture or a single component. It must contain target analyte(s) at approximately } \\
\text { the expected flue gas concentration(s). If possible, each mixture component } \\
\text { concentration should be NIST traceable ( } \pm 2 \text { percent accuracy)". This is part of } \\
\text { the Performance Specification for Extractive FTIR Continuous Emissions } \\
\text { Monitor Systems in Stationary Sources that form the Standards of Performance } \\
\text { for New Stationary Sources. }\end{array}$ & EPA & $\begin{array}{l}\text { 40 CFR } 60 \text { Appendix B } \\
\text { 15.9.1.1 }\end{array}$ \\
\hline Traceability & $\begin{array}{l}\text { Requires that "The owner or operator shall install, calibrate, operate, and } \\
\text { maintain a temperature monitor accurate to within } \pm 5.6^{\circ} \mathrm{C}\left( \pm 10^{\circ} \mathrm{F}\right) \text { to measure } \\
\text { the oxidation temperature. The owner or operator shall verify the accuracy of the } \\
\text { temperature monitor twice each calendar year with a reference temperature } \\
\text { monitor (traceable to National Institute of Standards and Technology (NIST) } \\
\text { standards or an independent temperature measurement device dedicated for this } \\
\text { purpose)" for sterilization facilities. This is part of the monitoring requirements } \\
\text { of the Ethylene Oxide Emissions Standards for Sterilization Facilities that form } \\
\text { the National Emission Standards for Hazardous Air Pollutants for Source } \\
\text { Categories. }\end{array}$ & EPA & 40 CFR 63.364(c)(4) \\
\hline
\end{tabular}




\begin{tabular}{|c|c|c|c|}
\hline Traceability & $\begin{array}{l}\text { Requires that "The owner or operator shall install, calibrate, operate, and } \\
\text { maintain a temperature monitor accurate to within } \pm 5.6^{\circ} \mathrm{C}\left( \pm 10^{\circ} \mathrm{F}\right) \text { to measure } \\
\text { the oxidation temperature". As an alternative to verifying the accuracy of the } \\
\text { temperature monitor with a reference temperature monitor, the operator or } \\
\text { owner can verify the accuracy of the temperature monitor "in a calibrated oven } \\
\text { (traceable to NIST standards)". This is part of the monitoring requirements of } \\
\text { the Ethylene Oxide Emissions Standards for Sterilization Facilities that form the } \\
\text { National Emission Standards for Hazardous Air Pollutants for Source } \\
\text { Categories. }\end{array}$ & EPA & 40 CFR $63.364(\mathrm{c})(4)$ \\
\hline Traceability & $\begin{array}{l}\text { Requires the installation, calibration, operation, and maintenance of a } \\
\text { temperature monitor accurate to within } \pm 5.6^{\circ} \mathrm{C}\left( \pm 10^{\circ} \mathrm{F}\right) \text { or within } 1 \text { percent of } \\
\text { the baseline temperature, whichever is less stringent, to measure the temperature } \\
\text { of a combustion device. It is further stated that "the owner or operator shall } \\
\text { verify the accuracy of the temperature monitor once each calendar year with a } \\
\text { reference temperature monitor (traceable to National Institute of Standards and } \\
\text { Technology (NIST) standards or an independent temperature measurement } \\
\text { device dedicated for this purpose)"(MANDATORY). This is part of the } \\
\text { monitoring requirements of National Emission Standards for Marine Tank } \\
\text { Vessel Loading Operations that form the National Emission Standards for } \\
\text { Hazardous Air Pollutants for Source Categories. }\end{array}$ & EPA & $\begin{array}{l}40 \text { CFR } 63.564 \\
\text { (e)(4) }\end{array}$ \\
\hline Traceability & $\begin{array}{l}\text { When using a carbon adsorber with steam regeneration, requires that "the owner } \\
\text { or operator will install, calibrate, maintain, and operate an integrating stream } \\
\text { flow monitoring device that is accurate within } \pm 10 \text { percent and that is capable of } \\
\text { recording the total stream mass flow for each regeneration cycle. The owner or } \\
\text { operator will install, calibrate, maintain, and operate a temperature monitor } \\
\text { accurate to within } \pm 5.6^{\circ} \mathrm{C}\left(10^{\circ} \mathrm{F}\right) \text { or within } 1 \text { percent of the baseline carbon bed } \\
\text { temperature, whichever is less stringent, to measure the carbon bed } \\
\text { temperature". Further requires that "the owner or operator shall verify the } \\
\text { accuracy of the temperature monitor once each calendar year with a reference } \\
\text { temperature monitor (traceable to National Institute of Standards and } \\
\text { Technology (NIST) standards or an independent temperature measurement } \\
\text { device dedicated for this purpose)"(MANDATORY). This is part of the } \\
\text { monitoring requirements of National Emission Standards for Marine Tank } \\
\text { Vessel Loading Operations that form the National Emission Standards for } \\
\text { Hazardous Air Pollutants for Source Categories. }\end{array}$ & EPA & 40 CFR $63.564(\mathrm{~g})(3)$ \\
\hline
\end{tabular}




\begin{tabular}{|c|c|c|c|c|}
\hline Traceability & $\begin{array}{l}\text { Requires the installation, calibration, operation, and maintenance of a } \\
\text { temperature monitor accurate to within } \pm 5.6^{\circ} \mathrm{C}\left( \pm 10^{\circ} \mathrm{F}\right) \text { or within } 1 \text { percent of } \\
\text { the baseline temperature, whichever is less stringent, to measure the temperature } \\
\text { of a condensor/refrigeration unit. It is further stated that "the owner or operator } \\
\text { shall verify the accuracy of the temperature monitor once each calendar year } \\
\text { with a reference temperature monitor (traceable to National Institute of } \\
\text { Standards and Technology (NIST) standards or an independent temperature } \\
\text { measurement device dedicated for this purpose)"(MANDATORY). This is part } \\
\text { of the monitoring requirements of National Emission Standards for Marine Tank } \\
\text { Vessel Loading Operations that form the National Emission Standards for } \\
\text { Hazardous Air Pollutants for Source Categories. }\end{array}$ & & EPA & 40 CFR 63.564(h)(1) \\
\hline Traceability & $\begin{array}{l}\text { Absolute Calibration Audit (ACA) is defined as "Equivalent to calibration error } \\
\text { (CE) test defined in the appropriate performance specification using NIST } \\
\text { traceable calibration standards to challenge the CEMS (continuous emissions } \\
\text { monitoring system) and assess accuracy". This definition is spelled under the } \\
\text { Quality Assurance Procedures for Continuous Emissions Monitors Used for } \\
\text { Hazardous Waste Combustors provided as an appendix to the sub-part on } \\
\text { National Emission Standards for Hazardous Air Pollutants from Hazardous } \\
\text { Waste Combustors under the National Emission Standards for Hazardous Air } \\
\text { Pollutants for Source Categories. }\end{array}$ & & EPA & $\begin{array}{l}40 \text { CFR } 63 \text { Subpart EEE; } \\
\text { Appendix }\end{array}$ \\
\hline Handbook 44 & $\begin{array}{l}\text { Refers to Handbook } 44 \text { to define the requirements of the scale used to measure } \\
\text { the weight of Hazardous Air Pollutants Auxiliary Blowing Agent (HAP ABA) } \\
\text { as part of the monitoring requirements for national emission standards for } \\
\text { hazardous air pollutants for flexible polyurethane foam production. }\end{array}$ & 1998 & EPA & 40 CFR 63.1303(e)(3) \\
\hline Traceability & $\begin{array}{l}\text { This part of the regulation requires that for each continuous parameter } \\
\text { monitoring system (CPMS), except for redundant sensors, any device that is } \\
\text { used to conduct an initial validation or accuracy audit of a CPMS must have an } \\
\text { accuracy that is traceable to National Institute of Standards and Technology } \\
\text { (NIST) standards, in addition to other requirements (MANDATORY). This } \\
\text { requirement is part of the testing and initial compliance requirements under the } \\
\text { National Emission Standards for Hazardous Air Pollutants for Cellulose } \\
\text { Products Manufacturing (subpart) that form the National Emission Standards for } \\
\text { Hazardous Air Pollutants for Source Categories. }\end{array}$ & & EPA & 40 CFR 63.5545(f)(9)(i) \\
\hline Traceability & $\begin{array}{l}\text { Regulation requires that any device used to conduct an initial validation or } \\
\text { accuracy audit of CPMS (continuous parametric monitoring system) must "have } \\
\text { an accuracy that is traceable to National Institute of Standards and Technology } \\
\text { (NIST) standards", amongst other requirements (MANDATORY). This } \\
\text { requirement is part of the testing and initial compliance requirements under the } \\
\text { National Emission Standards for Hazardous Air Pollutants for Refractory } \\
\text { Products Manufacturing (subpart) that form the National Emission Standards for } \\
\text { Hazardous Air Pollutants for Source Categories. }\end{array}$ & & EPA & 40 CFR 63.9804(a)(15)(i) \\
\hline
\end{tabular}




\begin{tabular}{|c|c|c|c|}
\hline $\begin{array}{l}\text { NIST certified } \mathrm{pH} \text { buffer } \\
\text { solution }\end{array}$ & $\begin{array}{l}\text { This part of the regulation requires that an initial validation of the pH CPMS be } \\
\text { conducted by performing "a single-point calibration using an NIST-certified } \\
\text { buffer solution that is accurate to within } \pm 0.02 \mathrm{pH} \text { units at } 25^{\circ} \mathrm{C}\left(77^{\circ} \mathrm{F}\right) \text {. If the } \\
\text { expected } \mathrm{pH} \text { of the liquid that is monitored lies in the acidic range (less than } 7 \\
\mathrm{pH}) \text {, use a buffer solution with a pH value of } 4.00 \text {. If the expected } \mathrm{pH} \text { of the } \\
\text { liquid that is monitored is neutral or lies in the basic range (equal to or greater } \\
\text { than } 7 \mathrm{pH}) \text {, use a buffer solution with a pH value of } 10.00 \text {. Place the electrode of } \\
\text { your } \mathrm{pH} \text { CPMS in the container of buffer solution. Record the } \mathrm{pH} \text { measured by } \\
\text { your CPMS. Using the certified buffer solution as the reference, the pH } \\
\text { measured by your CPMS must be within the accuracy specified in paragraph } \\
\text { (e)(1) of this section"(MANDATORY). This requirement is part of the testing } \\
\text { and initial compliance requirements under the National Emission Standards for } \\
\text { Hazardous Air Pollutants for Refractory Products Manufacturing (subpart) that } \\
\text { form the National Emission Standards for Hazardous Air Pollutants for Source } \\
\text { Categories. }\end{array}$ & EPA & 40 CFR $63.9804(\mathrm{e})(3)(\mathrm{i})$ \\
\hline $\begin{array}{l}\text { NIST certified } \mathrm{pH} \text { buffer } \\
\text { solution }\end{array}$ & $\begin{array}{l}\text { This part of the regulation requires that an accuracy audit of the } \mathrm{pH} \text { CPMS be } \\
\text { conducted at least weekly "If your } \mathrm{pH} \text { CPMS does not include a redundant } \mathrm{pH} \\
\text { sensor, perform a single point calibration using an NIST-certified buffer solution } \\
\text { that is accurate to within } \pm 0.02 \mathrm{pH} \text { units at } 25^{\circ} \mathrm{C}\left(77^{\circ} \mathrm{F}\right) \text {. If the expected } \mathrm{pH} \text { of } \\
\text { the liquid that is monitored lies in the acidic range (less than } 7 \mathrm{pH}) \text {, use a buffer } \\
\text { solution with a pH value of } 4.00 \text {. If the expected pH of the liquid that is } \\
\text { monitored is neutral or lies in the basic range (equal to or greater than } 7 \mathrm{pH}) \text {, use } \\
\text { a buffer solution with a pH value of } 10.00 \text {. Place the electrode of the pH CPMS } \\
\text { in the container of buffer solution. Record the pH measured by your CPMS. } \\
\text { Using the certified buffer solution as the reference, the pH measured by your } \\
\text { CPMS must be within the accuracy specified in paragraph (e)(1) of this section" } \\
\text { (MANDATORY). This requirement is part of the testing and initial compliance } \\
\text { requirements under the National Emission Standards for Hazardous Air } \\
\text { Pollutants for Refractory Products Manufacturing (subpart) that form the } \\
\text { National Emission Standards for Hazardous Air Pollutants for Source } \\
\text { Categories. }\end{array}$ & EPA & 40 CFR 63.9804(e)(4)(ii) \\
\hline
\end{tabular}




\begin{tabular}{|c|c|c|c|}
\hline $\begin{array}{l}\text { calibration gas, reference } \\
\text { material }\end{array}$ & $\begin{array}{l}\text { Defines that "Calibration gas" means:(1) A standard reference material;(2) A } \\
\text { standard reference material-equivalent compressed gas primary reference } \\
\text { material;(3) A NIST traceable reference material;(4) NIST/EPA-approved } \\
\text { certified reference materials;(5) A gas manufacturer's intermediate standard;(6) } \\
\text { An EPA protocol gas;(7) Zero air material; or(8) A research gas mixture. }\end{array}$ & EPA & 40 CFR 72.2 \\
\hline $\begin{array}{l}\text { reference material, } \\
\text { traceability }\end{array}$ & $\begin{array}{l}\text { States that "Gas manufacturer's intermediate standard (GMIS) means a } \\
\text { compressed gas calibration standard that has been assayed and certified by direct } \\
\text { comparison to a standard reference material (SRM), an SRM-equivalent PRM, a } \\
\text { NIST/EPA-approved certified reference material (CRM), or a NIST traceable } \\
\text { reference material (NTRM), in accordance with section 2.1.2.1 of the "EPA } \\
\text { Traceability Protocol for Assay and Certification of Gaseous Calibration } \\
\text { Standards," September 1997, EPA-600/R-97/121." }\end{array}$ & EPA & 40 CFR 72.2 \\
\hline reference material & $\begin{array}{l}\text { Defines NIST/EPA-approved certified reference material or NIST/EPA- } \\
\text { approved CRM as "a calibration gas mixture that has been approved by EPA and } \\
\text { the National Institutes of Standards and Technologies (NIST) as having specific } \\
\text { known chemical or physical property values certified by a technically valid } \\
\text { procedure as evidenced by a certificate or other documentation issued by a } \\
\text { certifying standard-setting body." }\end{array}$ & EPA & 40 CFR 72.2 \\
\hline reference material & $\begin{array}{l}\text { Defines NIST traceable reference material (NTRM) as "a calibration gas mixture } \\
\text { tested by and certified by the National Institutes of Standards and Technologies } \\
\text { (NIST) to have a certain specified concentration of gases. NTRMs may have } \\
\text { different concentrations from those of standard reference materials." }\end{array}$ & EPA & 40 CFR 72.2 \\
\hline
\end{tabular}




\begin{tabular}{|c|c|c|c|}
\hline Traceability & $\begin{array}{l}\text { Defines Research gas material (RGM) as "a calibration gas mixture developed } \\
\text { by agreement of a requestor and the National Institutes for Standards and } \\
\text { Technologies (NIST) that NIST analyzes and certifies as "NIST traceable." } \\
\text { RGMs may have concentrations different from those of standard reference } \\
\text { materials." }\end{array}$ & EPA & 40 CFR 72.2 \\
\hline Traceability & $\begin{array}{l}\text { Defines Research gas mixture (RGM) as "a calibration gas mixture developed by } \\
\text { agreement of a requestor and NIST that NIST analyzes and certifies as "NIST } \\
\text { traceable." RGMs may have concentrations different from those of standard } \\
\text { reference materials." }\end{array}$ & EPA & 40 CFR 72.2 \\
\hline SRM & $\begin{array}{l}\text { Defines Standard reference material or SRM as "a calibration gas mixture issued } \\
\text { and certified by NIST as having specific known chemical or physical property } \\
\text { values." }\end{array}$ & EPA & 40 CFR 72.2 \\
\hline SRM & $\begin{array}{l}\text { Defines Standard reference material-equivalent compressed gas primary } \\
\text { reference material (SRM-equivalent PRM) as "those gas mixtures listed in a } \\
\text { declaration of equivalence in accordance with section } 2.1 .2 \text { of the "EPA } \\
\text { Traceability Protocol for Assay and Certification of Gaseous Calibration } \\
\text { Standards," September 1997, EPA-600/R-97/121." }\end{array}$ & & \\
\hline NIST Traceable equipment & $\begin{array}{l}\text { This regulation states that the operator shall record applicable information } \\
\text { "..expected transmitter output during accuracy test (reference value from NIST- } \\
\text { traceable equipment), including units of measure;.." as part of the record keeping } \\
\text { requirements for continuous emissions monitoring. }\end{array}$ & EPA & 40 CFR 75.59(b)(2)(iii) \\
\hline NIST Traceability certificates & $\begin{array}{l}\text { This regulation states that "the designated representative for an affected unit may } \\
\text { apply to the Administrator for an alternative to any standard incorporated by } \\
\text { reference and prescribed in this part. The designated representative shall include } \\
\text { the following information in an application..." "Information demonstrating that } \\
\text { the proposed alternative produces data acceptable for use in the Acid Rain } \\
\text { Program, including accuracy and precision statements, NIST traceability } \\
\text { certificates or protocols, or other supporting data, as applicable to the proposed } \\
\text { alternative" in addition to other information, as part of the reporting } \\
\text { requirements for continuous emissions monitoring. }\end{array}$ & EPA & 40 CFR 75.66(c)(3) \\
\hline SRM & $\begin{array}{l}\text { Reference is made to NIST SRMs as a source of calibration gases as part of the } \\
\text { specifications and test procedures for continuous emissions monitoring }\end{array}$ & EPA & $\begin{array}{l}\text { 40 CFR 75, Appendix A } \\
5.1 .2\end{array}$ \\
\hline Reference Material & $\begin{array}{l}\text { Reference is made to a NIST OU as a source of list of vendors and cylinder } \\
\text { gases for SRM-Equivalent Compressed Gas Primary Reference Material (PRM) } \\
\text { as part of the specifications and test procedures for continuous emissions } \\
\text { monitoring }\end{array}$ & EPA & $\begin{array}{l}\text { 40 CFR75, Appendix A } \\
5.1 .1\end{array}$ \\
\hline $\begin{array}{l}\text { Traceability/Reference } \\
\text { Materials }\end{array}$ & $\begin{array}{l}\text { Reference is made to a NIST OU as a source of list of vendors and cylinder } \\
\text { gases for NIST traceable reference materials as part of the specifications and test } \\
\text { procedures for continuous emissions monitoring }\end{array}$ & EPA & $\begin{array}{l}\text { 40 CFR 75, Appendix A } \\
5.1 .3\end{array}$ \\
\hline
\end{tabular}




\begin{tabular}{|c|c|c|c|}
\hline Reference Materials & $\begin{array}{l}\text { Refers to a NIST OU for information about the "Research Gas Mixture (RGM) } \\
\text { program" as part of the specifications and test procedures for continuous } \\
\text { emissions monitoring }\end{array}$ & EPA & $\begin{array}{l}40 \text { CFR75, Appendix A } \\
\text { 5.1.5 }\end{array}$ \\
\hline Reference Materials & $\begin{array}{l}\text { This regulation refers to NIST/EPA-Approved Certified Reference Materials } \\
\text { stating that existing certified reference materials (CRMs) that are still within } \\
\text { their certification period may be used as calibration gas as part of the } \\
\text { specifications and test procedures for continuous emissions monitoring }\end{array}$ & EPA & $\begin{array}{l}40 \text { CFR75, Appendix A } \\
5.1 .7\end{array}$ \\
\hline $\begin{array}{l}\text { Traceability to NIST } \\
\text { standards }\end{array}$ & $\begin{array}{l}\text { This regulation refers to procedures in various standards to verify flowmeter } \\
\text { accuracy. It further states that the EPA "Administrator may also approve other } \\
\text { procedures that use equipment traceable to National Institute of Standards and } \\
\text { Technology standards ". This requirement is part of the initial certification } \\
\text { requirements for all fuel flowmeters when following optional SO2 emissions } \\
\text { data protocol for gas-fired and oil-fired units for continuous emissions } \\
\text { monitoring. }\end{array}$ & EPA & $\begin{array}{l}\text { 40 CFR75, Appendix D } \\
\text { 2.1.5.1 }\end{array}$ \\
\hline $\begin{array}{l}\text { Traceability to NIST } \\
\text { standards }\end{array}$ & $\begin{array}{l}\text { Regulation states that while conducting transmitter or transducer accuracy tests } \\
\text { for orifice-, nozzle- and venturi- type flowmeters "Calibrate the differential } \\
\text { pressure transmitter or transducer, static pressure transmitter or transducer, and } \\
\text { temperature transmitter or transducer, as applicable, using equipment that has a } \\
\text { current certificate of traceability to NIST standards" (MANDATORY). This } \\
\text { requirement is part of the initial certification requirements for all fuel } \\
\text { flowmeters when following optional SO2 emissions data protocol for gas-fired } \\
\text { and oil-fired units for continuous emissions monitoring. }\end{array}$ & EPA & $\begin{array}{l}40 \text { CFR75, Appendix D } \\
\text { 2.1.6.1(a) }\end{array}$ \\
\hline $\begin{array}{l}\text { NIST Traceable reference } \\
\text { value }\end{array}$ & $\begin{array}{l}\text { Regulation states that while conducting transmitter or transducer accuracy tests } \\
\text { for orifice-, nozzle- and venturi- type flowmeters he calibration of each } \\
\text { transmitter or transducer should be checked "by comparing its readings to that of } \\
\text { the NIST traceable equipment at least once at each of the following levels: the } \\
\text { zero-level and at least two other upscale levels (e.g., "mid" and "high"), such } \\
\text { that the full range of transmitter or transducer readings corresponding to normal } \\
\text { unit operation is represented .."(MANDATORY). This requirement is part of } \\
\text { the initial certification requirements for all fuel flowmeters when following } \\
\text { optional SO2 emissions data protocol for gas-fired and oil-fired units for } \\
\text { continuous emissions monitoring. }\end{array}$ & EPA & $\begin{array}{l}40 \text { CFR 75, Appendix D } \\
\text { 2.1.6.1(a) }\end{array}$ \\
\hline NIST Traceable equipment & $\begin{array}{l}\text { This sub-section refers to the NIST traceable reference value for determination } \\
\text { of the accuracy of the transmitter or transducer as a percentage of the full scale, } \\
\text { in the equation used to determine the accuracy (MANDATORY). This } \\
\text { requirement is part of the initial certification requirements for all fuel } \\
\text { flowmeters when following optional SO } 2 \text { emissions data protocol for gas-fired } \\
\text { and oil-fired units for continuous emissions monitoring. }\end{array}$ & EPA & $\begin{array}{l}40 \text { CFR75, Appendix D } \\
\text { 2.1.6.1(b) }\end{array}$ \\
\hline
\end{tabular}




\begin{tabular}{|c|c|c|c|}
\hline NBS Accredited Laboratories & $\begin{array}{l}\text { This regulation pertains to analysis of asbestos containing materials in schools } \\
\text { and states that "Local education agencies shall have bulk samples, collected } \\
\text { under } § 763.86 \text { and submitted for analysis, analyzed for asbestos using } \\
\text { laboratories accredited by the National Bureau of Standards (NBS). Local } \\
\text { education agencies shall use laboratories which have received interim } \\
\text { accreditation for polarized light microscopy (PLM) analysis under the EPA } \\
\text { Interim Asbestos Bulk Sample Analysis Quality Assurance Program until the } \\
\text { NBS PLM laboratory accreditation program for PLM is operational." }\end{array}$ & EPA & 40 CFR 763.87(a) \\
\hline NBS Accredited Laboratories & $\begin{array}{l}\text { This regulation pertains to response actions to asbestos containing materials in } \\
\text { schools and states that "Local education agencies shall have air samples } \\
\text { collected under this section analyzed for asbestos using laboratories accredited } \\
\text { by the National Bureau of Standards to conduct such analysis using transmission } \\
\text { electron microscopy (TEM) or, under circumstances permitted in this section, } \\
\text { laboratories enrolled in the American Industrial Hygiene Association } \\
\text { Proficiency Analytical Testing Program for phase contrast microscopy (PCM)." }\end{array}$ & EPA & 40 CFR 763.90(h)(2)(ii) \\
\hline Accreditation & $\begin{array}{l}\text { This regulation refers to the NIST NVLAP and states that "EPA recommends } \\
\text { that transmission electron microscopy (TEM) be used for analysis of final air } \\
\text { clearance samples, and that sample analyses be performed by laboratories } \\
\text { accredited by the National Institute of Standards and Technology's (NIST) } \\
\text { National Voluntary Laboratory Accreditation Program (NVLAP)" as part of the } \\
\text { air monitoring requirements in the procedures to determine airborne } \\
\text { concentrations of asbestos fibers, as part of the Asbestos Model Accreditation } \\
\text { Plan for States. }\end{array}$ & EPA & $\begin{array}{l}40 \text { CFR } 763 \text { Appendix C } \\
\text { I.B.2(h) }\end{array}$ \\
\hline SRM/RM & $\begin{array}{l}\text { Reference is made to analysis of NBS SRM } 1876 \text { and RM } 8410 \text { as a measure of } \\
\text { accuracy and comparability. This analysis has to be conducted at least once per } \\
\text { analyst per year as a quality control/quality assurance procedure to be performed } \\
\text { along with the sample analysis as indicators that the materials used are adequate } \\
\text { and the operations are within acceptable limits. This is part of the requirements } \\
\text { listed under "Interim Transmission Electron Microscopy Analytical Methods- } \\
\text { Mandatory and Nonmandatory-and Mandatory Section to Determine } \\
\text { Completion of Response Actions" as a mandatory Transmission Electron } \\
\text { Microscopy method for asbestos related analyses.(MANDATORY) }\end{array}$ & EPA & $\begin{array}{l}40 \text { CFR } 763 \text { (II.)(I) Table } \\
\text { III. }\end{array}$ \\
\hline SRM/RM & $\begin{array}{l}\text { Reference is made to analysis of NBS SRM } 1876 \text { and RM } 8410 \text { as a measure of } \\
\text { accuracy and comparability. This analysis has to be conducted at least once per } \\
\text { analyst per year as a quality control/quality assurance procedure to be performed } \\
\text { along with the sample analysis as indicators that the materials used are adequate } \\
\text { and the operations are within acceptable limits. This is part of the requirements } \\
\text { listed under "Interim Transmission Electron Microscopy Analytical Methods- } \\
\text { Mandatory and Nonmandatory-and Mandatory Section to Determine } \\
\text { Completion of Response Actions" as a non-mandatory Transmission Electron } \\
\text { Microscopy method for asbestos related analyses. }\end{array}$ & EPA & $\begin{array}{l}40 \text { CFR } 763 \text { (III.)(K) } \\
\text { Table III. }\end{array}$ \\
\hline
\end{tabular}




\begin{tabular}{|c|c|c|c|}
\hline JCPSD-ICDD & $\begin{array}{l}\text { Reference is made to the standard reference powder diffraction patterns } \\
\text { contained in "JCPDS-International Center for Diffraction Data Powder } \\
\text { Diffraction File, U.S. Department of Commerce, National Bureau of Standards, } \\
\text { and Joint Committee on Powder Diffraction Studies, Swarthmore, PA", against } \\
\text { which all samples that exhibit diffraction peaks in the diagnostic regions for } \\
\text { asbestiform minerals are submitted to a full }\left(5^{\circ}-60^{\circ} 2 \Theta ; 1^{\circ} 2 \Theta / \text { min) qualitative }\right. \\
\text { XRD scan, and their diffraction patterns are compared to verify initial peak } \\
\text { assignments and to identify possible matrix interferences when subsequent } \\
\text { quantitative analysis will be performed. This is required when X-ray powder } \\
\text { diffraction is used as an interim method for determination of asbestos in bulk } \\
\text { insulation samples for testing of asbestos containing materials in schools. }\end{array}$ & EPA & $\begin{array}{l}40 \text { CFR } 763 \text { Appendix E } \\
\text { 2.10 Ref. } 3\end{array}$ \\
\hline NBS Publication 506 & $\begin{array}{l}\text { Reference is made to "J. B. Krause and W. H. Ashton, Misidentification of } \\
\text { asbestos in talc, pp. 339-353, in: Proceedings of Workshop on Asbestos: } \\
\text { Definitions and Measurement Methods (NBS Special Publication 506), C. C. } \\
\text { Gravatt, P. D. LaFleur, and K. F. Heinrich (eds.), Washington, DC: National } \\
\text { Measurement Laboratory, National Bureau of Standards, } 1977 \text { (issued 1978)" to } \\
\text { elucidate possible reasons for interferences in XRD analyses of asbestiform } \\
\text { materials, and related specimen preparation. This is in the context of X-ray } \\
\text { powder diffraction being used as an interim method for determination of } \\
\text { asbestos in bulk insulation samples for testing of asbestos containing materials } \\
\text { in schools. }\end{array}$ & EPA & $\begin{array}{l}\text { 40 CFR } 763 \text { Appendix E } \\
\text { 2.10 Ref. } 11\end{array}$ \\
\hline NBS Publication 506 & $\begin{array}{l}\text { Reference is made to "H. D. Stanley, The detection and identification of asbestos } \\
\text { and asbesti-form minerals in talc, pp. 325-337, in Proceedings of Workshop on } \\
\text { Asbestos: Definitions and Measurement Methods (NBS Special Publication } \\
\text { 506), C. C. Gravatt, P. D. LaFleur, and K. F. Heinrich (eds.), Washington, DC, } \\
\text { National Measurement Laboratory, National Bureau of Standards, } 1977 \text { (issued } \\
\text { 1978)" in explaining the difficulties associated with definitive identification of } \\
\text { the asbestos minerals by comparison with standard reference diffraction patterns } \\
\text { due to alterations in the crystal lattice associated with differences in } \\
\text { isomorphous substitution and degree of crystallinity, particularly for the } \\
\text { amphiboles. This is in the context of X-ray powder diffraction being used as an } \\
\text { interim method for determination of asbestos in bulk insulation samples for } \\
\text { testing of asbestos containing materials in schools. }\end{array}$ & $\mathrm{EPA}$ & $\begin{array}{l}40 \text { CFR } 763 \text { Appendix E } \\
\text { 2.10 Ref. } 12\end{array}$ \\
\hline
\end{tabular}




\begin{tabular}{|c|c|c|c|c|}
\hline NBS Publication 506 & $\begin{array}{l}\text { Reference is made to "J. C. Haartz, B. A. Lange, R. G. Draftz, and R. F. Scholl, } \\
\text { Selection and characterization of fibrous and nonfibrous amphiboles for } \\
\text { analytical methods development, pp. 295-312, in: Proceedings of Workshop on } \\
\text { Asbestos: Definitions and Measurement Methods (NBS Special Publication } \\
\text { 506), C. C. Gravatt, P. D. LaFleur, and K. F. Heinrich (eds.), Washington, DC: } \\
\text { National Measurement Laboratory, National Bureau of Standards, } 1977 \text { (issued } \\
\text { 1978)" to underscore the problem of obtaining and characterizing suitable } \\
\text { reference materials for asbestos analysis. Though such analytical reference } \\
\text { materials maybe available, it is believed that they are not available in large } \\
\text { quantities for routine analyses. This is in the context of X-ray powder diffraction } \\
\text { being used as an interim method for determination of asbestos in bulk insulation } \\
\text { samples for testing of asbestos containing materials in schools. }\end{array}$ & & EPA & $\begin{array}{l}40 \text { CFR } 763 \text { Appendix E } \\
\text { 2.10 Ref. } 17\end{array}$ \\
\hline NBS publication & $\begin{array}{l}\text { States that the TSCA (Toxic Substances Control Act) partition coefficient (n- } \\
\text { octanol/water), generator column test method is based on the DCCLC technique } \\
\text { for determining the aqueous solubility of organic compounds referred to in the } \\
\text { NBS publication "DeVoe, H. et al. "Generator Columns and High Pressure } \\
\text { Liquid Chromatography for Determining Aqueous Solubilities and Octanol- } \\
\text { Water Partition Coefficients of Hydrophobic Substances," Journal of Research } \\
\text { of the National Bureau of Standards, } 86: 361-366 \text { (1981)" . This regulation states } \\
\text { that product property test guidelines for identification of specific chemical } \\
\text { substance and mixture testing requirements. }\end{array}$ & 1981 & EPA & 40 CFR 799.6756(b)(3) \\
\hline NBS publication & $\begin{array}{l}\text { Refers to NBS publication "DeVoe, H. et al. "Generator Columns and High } \\
\text { Pressure Liquid Chromatography for Determining Aqueous Solubilities and } \\
\text { Octanol-Water Partition Coefficients of Hydrophobic Substances," Journal of } \\
\text { Research of the National Bureau of Standards, 86:361-366 (1981)" to state how } \\
\text { an accurate measurement of the sample loop may be accomplished by using a } \\
\text { spectrophotometric method as part of the product property test guidelines for } \\
\text { identification of specific chemical substance and mixture testing requirements in } \\
\text { response to the TSCA. }\end{array}$ & 1981 & EPA & $\begin{array}{l}40 \text { CFR } \\
799.6756(\mathrm{c})(3)(\mathrm{iii})(\mathrm{C})(1)\end{array}$ \\
\hline NBS publication & $\begin{array}{l}\text { States that the TSCA (Toxic Substances Control Act) partition coefficient (n- } \\
\text { octanol/water), generator column test method is based on the DCCLC technique } \\
\text { for determining the aqueous solubility of organic compounds referred to in the } \\
\text { NBS publication "Wasik, S.P. et al. Octanol/water partition coefficient and } \\
\text { aqueous solubilities of organic compounds, Report NBSIR 81-2406 (1981) } \\
\text { National Bureau of Standards, U.S. Department of Commerce, Washington, } \\
\text { DC" . This regulation states that product property test guidelines for } \\
\text { identification of specific chemical substance and mixture testing requirements in } \\
\text { response to the TSCA. }\end{array}$ & 1981 & EPA & 40 CFR 799.6756(b)(3) \\
\hline
\end{tabular}




\begin{tabular}{|c|c|c|c|c|}
\hline NBS publication & $\begin{array}{l}\text { Refers to the NBS publication "Wasik, S.P. et al. Octanol/water partition } \\
\text { coefficient and aqueous solubilities of organic compounds, Report NBSIR } 81- \\
2406 \text { (1981) National Bureau of Standards, U.S. Department of Commerce, } \\
\text { Washington, DC" as the source of information on n-Octanol/Water Partition } \\
\text { Coefficient at } 25^{\circ} \mathrm{C} \text { for some reference compounds so that the generator column } \\
\text { method can be calibrated, and to allow the chemical laboratory the opportunity } \\
\text { to compare its results with these values. This regulation states that product } \\
\text { property test guidelines for identification of specific chemical substance and } \\
\text { mixture testing requirements. }\end{array}$ & 1981 & EPA & $\begin{array}{l}40 \text { CFR } \\
799.6756(b)(4)(i i)\end{array}$ \\
\hline NBS Publication & $\begin{array}{l}\text { Refers to NBS publication "DeVoe, H. et al., Generator columns and high } \\
\text { pressure liquid chromatography for determining aqueous solubilities and } \\
\text { octanol-water partition coefficients of hydrophobic substances. Journal of } \\
\text { Research, National Bureau of Standards, 86:361-366 (1981)" to state how } \\
\text { accurate measurements of a sample loop can be accomplished when using } \\
\text { spectrophotometric methods. The same publication is also referred to define the } \\
\text { principle of the test method based on the dynamic coupled column liquid } \\
\text { chromatographic (DCCLC) technique for determining the aqueous solubility of } \\
\text { organic compounds". These references are in support of tests intended to meet } \\
\text { the testing requirements of the Toxic Substances Control Act (TSCA), as part of } \\
\text { the testing requirements for identification of specific chemical substances and } \\
\text { mixtures. }\end{array}$ & & EPA & 40 CFR 799.6786(e)(1) \\
\hline NBS Publication & $\begin{array}{l}\text { Reference is made to the NBS publication, "Wasik, S.P. et al., Octanol/Water } \\
\text { Partition Coefficient and Aqueous Solubilities of Organic Compounds. NBS } \\
\text { Report NBSIR 81-2406. Washington, DC: National Bureau of Standards, U.S. } \\
\text { Department of Commerce (1981)". This publication is referred to define the } \\
\text { "principle of the test method based on the dynamic coupled column liquid } \\
\text { chromatographic (DCCLC) technique for determining the aqueous solubility of } \\
\text { organic compounds". Also, this reference has been used to obtain data for water } \\
\text { solubilities at } 25^{\circ} \mathrm{C} \text { for a number of reference chemicals and stated as part of } \\
\text { this regulation. These references are in support of tests intended to meet the } \\
\text { testing requirements of the Toxic Substances Control Act (TSCA), as part of the } \\
\text { testing requirements for identification of specific chemical substances and } \\
\text { mixtures. }\end{array}$ & & EPA & 40 CFR 799.6786(e)(11) \\
\hline
\end{tabular}


Reference to NIST standard for statement of accuracy

NBS Lead-in-reference fuel
standard

NBS Lead-in-reference fuel

standard

Traceability to NBS Standard

Traceability to NIST standard
Reference is made to a NBS lead in reference fuel to make a statement on the accuracy of the measurement, as "The analysis of National Bureau of Standards (NBS) lead in reference fuel of known concentrations in a single laboratory has resulted in found values deviating from the true value for 11 determinations of $0.0322 \mathrm{~g} \mathrm{~Pb} / \mathrm{gal}$ by an average of $0.56 \%$ with a standard deviation of $6.8 \%$, for 15 determinations of $0.0519 \mathrm{~g} \mathrm{~Pb} / \mathrm{gal}$ by an average of $-1.1 \%$ with a standard deviation of $5.8 \%$, and for 7 determinations of $0.0725 \mathrm{~g} \mathrm{~Pb} /$ gal by an average of $3.5 \%$ with a standard deviation of $4.8 \% "$. This statement applies to automated method test for determination of lead in gasoline by Atomic Absorption Spectrometry, as part of the regulations for fuels and fuel additives.

This regulation stipulates that the suitability of a calibration curve used in the test procedure for testing of lead in gasoline by X-ray spectrometry should be checked each day "by analyzing several National Bureau of Standards (NBS) lead-in-reference-fuel standards or other suitable standards".

It is required that "quality control standards, such as NBS standard reference materials, should be analyzed at least once every testing session" when testing of lead in gasoline by X-ray spectrometry (MANDATORY).

This regulation states that span gases used in weekly checks of analyzers used as part of emission control system performance warranty short tests, "shall be traceable to NBS standards $\pm 2 \%$ and have" in addition to other requirements for concentration (MANDATORY). This regulation is a subpart of testing for control of air pollution from mobile sources. This regulation further stipulates that "requirements of $\$ 85.2233$ apply concurrently until December 31, 1993, after which the requirements of $\$ 85.2233$ are solely in effect"

This regulation specifies the requirements for span gases for gas calibration conducted as part of the steady state test equipment calibrations, adjustment and quality control conducted in emission control systems performance warranty short tests for control of air pollution from mobile sources. This regulation states that in addition to other requirements, span gases "must be traceable to National Institute of Standards and Technology (NIST) standards within two percent"

Calibration gases- States that calibration gases used in test procedures for Emission Regulations for 1977 and Later Model Year (in this case from 1979 onwards, till superseded) New Light-Duty Vehicles and New Light-Duty Trucks and New Otto-Cycle Complete Heavy-Duty Vehicles "shall be traceable to within 1 percent of NBS gas standards, or other gas standards which have been approved by the Administrator."

\begin{tabular}{|c|c|c|}
\hline & EPA & $\begin{array}{l}40 \text { CFR } 80 \text { - Appendix B } \\
\text { (Subpart J); Method 2, } \\
\text { 10.2.1 }\end{array}$ \\
\hline & EPA & $\begin{array}{l}\text { 40 CFR } 80 \text { - Appendix B } \\
\text { (Subpart J); Method 3, } 7.1\end{array}$ \\
\hline & EPA & $\begin{array}{l}\text { 40 CFR } 80 \text { - Appendix B } \\
\text { (Subpart J); Method 3, } 7.4\end{array}$ \\
\hline & EPA & 40 CFR 85.2232(e)(4) \\
\hline \multirow[t]{4}{*}{1994} & EPA & 40 CFR 85.2233(e)(3) \\
\hline & EPA & 40 CFR 86.114-79 (b) \\
\hline & & \\
\hline & & \\
\hline
\end{tabular}




\begin{tabular}{|c|c|c|c|}
\hline NBS Gas standards & $\begin{array}{l}\text { Span gases- States that Span gases used in test procedures for Emission } \\
\text { Regulations for } 1977 \text { and Later Model Year (in this case from } 1979 \text { onwards, till } \\
\text { superseded) New Light-Duty Vehicles and New Light-Duty Trucks and New } \\
\text { Otto-Cycle Complete Heavy-Duty Vehicles " shall be accurate to within } 2 \\
\text { percent of true concentration, where true concentration refers to NBS gas } \\
\text { standards, or other gas standards which have been approved by the } \\
\text { Administrator". }\end{array}$ & EPA & 41 CFR 86.114-79 (c) \\
\hline Traceability NIST standards & $\begin{array}{l}\text { Methanol in air gases- states that methanol in air gases used for response factor } \\
\text { determination in test procedures for Emission Regulations for } 1977 \text { and Later } \\
\text { Model Year (in this case from } 1994 \text { onwards, till superseded) New Light-Duty } \\
\text { Vehicles and New Light-Duty Trucks and New Otto-Cycle Complete Heavy- } \\
\text { Duty Vehicles "shall be traceable to within } \pm 2 \text { percent of NIST (formerly NBS) } \\
\text { gas standards, or other standards which have been approved by the } \\
\text { Administrator" (MANDATORY). }\end{array}$ & EPA & 40 CFR 86.114-94(d)(1) \\
\hline Traceability to NIST standard & $\begin{array}{l}\text { Calibration gases- States that calibration gases (except for methanol )used in test } \\
\text { procedures for Emission Regulations for } 1977 \text { and Later Model Year (in this } \\
\text { case from } 1994 \text { onwards, till superseded) New Light-Duty Vehicles and New } \\
\text { Light-Duty Trucks and New Otto-Cycle Complete Heavy-Duty Vehicles "shall } \\
\text { be traceable to within } 1 \text { percent of NIST (formerly NBS) gas standards, or other } \\
\text { gas standards which have been approved by the Administrator." }\end{array}$ & EPA & 40 CFR 86.114-94(b) \\
\hline NIST Gas Standards & $\begin{array}{l}\text { Span gases -States that Span gases (not including methanol) used in test } \\
\text { procedures for Emission Regulations for } 1977 \text { and Later Model Year (in this } \\
\text { case from } 1994 \text { onwards, till superseded) New Light-Duty Vehicles and New } \\
\text { Light-Duty Trucks and New Otto-Cycle Complete Heavy-Duty Vehicles " shall } \\
\text { be accurate to within two percent of true concentration, where true concentration } \\
\text { refers to NIST (formerly NBS) gas standards, or other gas standards which have } \\
\text { been approved by the Administrator." }\end{array}$ & EPA & 40 CFR 86.114-94(c) \\
\hline $\begin{array}{l}\text { Traceability to NBS flow } \\
\text { calibration device }\end{array}$ & $\begin{array}{l}\text { Flow calibration device-States that test procedures for gas meter or flow } \\
\text { instrumentation calibration for particulate, methanol and formaldehyde } \\
\text { measurement as part of testing for Emission Regulations for } 1977 \text { and Later } \\
\text { Model Year (in this case } 1994 \text { onwards, till superseded) New Light-Duty } \\
\text { Vehicles and New Light-Duty Trucks and New Otto-Cycle Complete Heavy- } \\
\text { Duty Vehicles require that "a calibration device be installed in series with the } \\
\text { instrument. A critical flow orifice, a bellmouth nozzle, a laminar flow element or } \\
\text { an NBS traceable flow calibration device is required as the standard device". }\end{array}$ & EPA & $\begin{array}{l}\text { 40 CFR 86.120- } \\
94(\mathrm{a})(1)(\mathrm{i})\end{array}$ \\
\hline
\end{tabular}




\begin{tabular}{|c|c|c|c|}
\hline Traceability & $\begin{array}{l}\text { known methane in air concentrations - States that "to determine the total } \\
\text { hydrocarbon FID response to methane, known methane in air concentrations } \\
\text { traceable to the National Institute of Standards and Technology (NIST) shall be } \\
\text { analyzed by the FID"-flame ionization detector, as part of the procedure for } \\
\text { hydrocarbon analyzer calibration defined as test procedures for Emission } \\
\text { Regulations for } 1977 \text { and Later Model Year (in this case } 1990 \text { onwards, till } \\
\text { superseded) New Light-Duty Vehicles and New Light-Duty Trucks and New } \\
\text { Otto-Cycle Complete Heavy-Duty Vehicles (MANDATORY) }\end{array}$ & EPA & 40 CFR 86.121-90(d) \\
\hline SRM & $\begin{array}{l}\text { Gas specifications: States that calibration gases used in Gaseous Exhaust Test } \\
\text { Procedures for Emission Regulations for New (model years } 1979 \text { and later) } \\
\text { Gasoline-Fueled and Diesel-Fueled Heavy-Duty Engines are to have "calibration } \\
\text { gas values derived from NBS "Standard Reference Materials" (SRMs) or other } \\
\text { gas standards approved by the Administrator. The uncertainty of the assigned } \\
\text { calibration gas values shall not exceed } 2.0 \text { percent of the assigned value. The } \\
\text { uncertainty is defined as the sum of the precision errors (at the } 90 \text { percent } \\
\text { confidence level) and the bias errors. Precision and bias errors apply to both the } \\
\text { equipment and the derivation procedures." }\end{array}$ & EPA & 40 CFR 86.308-79 (b) \\
\hline SRM & $\begin{array}{l}\text { Gas specifications: States that span gases used in Gaseous Exhaust Test } \\
\text { Procedures for Emission Regulations for New (model years } 1979 \text { and later) } \\
\text { Gasoline-Fueled and Diesel-Fueled Heavy-Duty Engines are to have "Span gas } \\
\text { values derived from NBS "Standard Reference Materials" (SRMs) or other gas } \\
\text { standards approved by the Administrator. The uncertainty of the assigned } \\
\text { calibration gas values shall not exceed } 3.0 \text { percent of the assigned value. The } \\
\text { uncertainty is defined as the sum of the precision errors (at the } 90 \text { percent } \\
\text { confidence level) and the bias errors. Precision and bias errors apply to both the } \\
\text { equipment and the derivation procedures". }\end{array}$ & EPA & 40 CFR 86.308-79(c) \\
\hline Traceability / NBS Standards & $\begin{array}{l}\text { NBS weights -states that for calibrating dynamometers as part of the } \\
\text { Dynamometer and Engine Equipment Specification for Emission Regulations } \\
\text { for New (model year } 1979 \text { and later) Gasoline-Fueled and Diesel-Fueled Heavy- } \\
\text { Duty Engines; Gaseous Exhaust Test Procedures "a minimum of } 6 \text { calibration } \\
\text { weights for each range used are required. The weights must be equally spaced } \\
\text { and traceable to within } 0.5 \text { percent of NBS weights. Laboratories located in } \\
\text { foreign countries may certify calibration weights to local government bureau } \\
\text { standards" (MANDATORY) }\end{array}$ & EPA & 40 CFR 86.312-79(a)(2) \\
\hline
\end{tabular}




\begin{tabular}{|c|c|c|c|}
\hline Traceability to NBS standards & $\begin{array}{l}\text { NBS weights -provides the option that a master load-cell or transfer standard } \\
\text { may be used to verify the in-use torque measurement system as part of the } \\
\text { dynamometer calibration procedure for Gaseous Exhaust Test Procedures } \\
\text { prescribed for Emission Regulations for New (in this case } 1979 \text { and later) } \\
\text { Gasoline-Fueled and Diesel-Fueled Heavy-Duty Engines. However, it is further } \\
\text { stated "that the master load-cell and read out system must be calibrated with } \\
\text { weights at each test weight specified in } \S 86.312-79 \text { and that the calibration } \\
\text { weights must be traceable to within } 0.1 \text { percent of NBS weights" }\end{array}$ & EPA & 40 CFR 86.333 .79 (c)(1) \\
\hline NBS publication & $\begin{array}{l}\text { Humidity Calculations - defines the saturation vapor pressure (PWB) of water at } \\
\text { the wet-bulb temperature using equation in an NBS publication. (ed. Note: No } \\
\text { information on what publication, except to state editors of publication as } \\
\text { Wexler, (A.), and Greenspan, (L.)) as part of Gaseous Exhaust Test Procedures } \\
\text { use in Emission Regulations for New (in this case } 1979 \text { and later) Gasoline- } \\
\text { Fueled and Diesel-Fueled Heavy-Duty Engines. }\end{array}$ & EPA & 40 CFR 86.344-79(d)(1) \\
\hline Traceability to NIST standard & $\begin{array}{l}\text { Analytical Gases - states that "Methanol in air gases used for response factor } \\
\text { determination shall be traceable to within } \pm 2 \text { percent of NIST (formerly NBS) } \\
\text { gas standards, or other gas standards which have been approved by the } \\
\text { Administrator" for test procedures used in Emission Regulations for } 1978 \text { and } \\
\text { Later New Motorcycles, as part of testing for control of emissions from new and } \\
\text { in-use highway vehicles and engines. }\end{array}$ & EPA & 40 CFR 86.514-78(c)(1) \\
\hline Traceability & $\begin{array}{l}\text { known methane in air concentrations -"FID response factor to methane"- States } \\
\text { that "when the FID analyzer is to be used for the analysis of natural gas-fueled } \\
\text { motorcycle hydrocarbon samples, the methane response factor of the analyzer } \\
\text { shall be established. To determine the total hydrocarbon FID response to } \\
\text { methane, known methane in air concentrations traceable to National Institute of } \\
\text { Standards and Technology (NIST) shall be analyzed by the FID. Several } \\
\text { methane concentrations shall be analyzed by the FID in the range of } \\
\text { concentrations in the exhaust sample." This is required for calibration of } \\
\text { hydrocarbon analyzers used in test procedures for Emission Regulations for } \\
1978 \text { (in this case } 1990 \text { onwards) and Later New Motorcycles as part of control } \\
\text { of emissions from new and in-use highway vehicles and engines. }\end{array}$ & EPA & 40 CFR 86.521-90 (e) \\
\hline $\begin{array}{l}\text { NBS Reference standards } \\
\text { (optical filters)/Calibration }\end{array}$ & $\begin{array}{l}\text { reference filters- requires that filters used for checking linearity of smokemeters } \\
\text { used in Smoke Exhaust Test Procedures in testing for Emission Regulations for } \\
\text { New Diesel Heavy-Duty Engines be checked for opacity annually using NBS or } \\
\text { equivalent reference filters. This requirement is part of testing for control of } \\
\text { emissions from new and in-use highway vehicles and engines. }\end{array}$ & EPA & 40 CFR 86.884-11(3) \\
\hline
\end{tabular}




\begin{tabular}{|c|c|c|c|}
\hline Traceability to NIST standard & $\begin{array}{l}\text { Calibration Gases- States that calibration gases (not including methanol) used in } \\
\text { an hydrocarbon analyzer in Evaporative Emission Test Procedures for New (in } \\
\text { this case } 1985 \text { and newer, until superseded) Gasoline-Fueled, Natural Gas- } \\
\text { Fueled, Liquefied Petroleum Gas-Fueled and Methanol-Fueled Heavy-Duty } \\
\text { Vehicles "shall be traceable to within one percent of NIST (formerly NBS) gas } \\
\text { standards, or other gas standards which have been approved by the } \\
\text { Administrator". This requirement is defined for control of emissions from new } \\
\text { and in-use highway vehicles and engines. }\end{array}$ & EPA & 40 CFR 86.1214-85(b) \\
\hline NIST Gas Standards & $\begin{array}{l}\text { Span Gases - States that Span gases (not including methanol) used in an } \\
\text { hydrocarbon analyzer in Evaporative Emission Test Procedures for New (in this } \\
\text { case } 1985 \text { and newer, until superseded)Gasoline-Fueled, Natural Gas- Fueled, } \\
\text { Liquefied Petroleum Gas-Fueled and Methanol-Fueled Heavy-Duty Vehicles } \\
\text { "shall be accurate to within two percent of true concentration, where true } \\
\text { concentration refers to NIST (formerly NBS) gas standards, or other gas } \\
\text { standards which have been approved by the Administrator." This requirement is } \\
\text { defined for control of emissions from new and in-use highway vehicles and } \\
\text { engines. }\end{array}$ & EPA & 40 CFR 86.1214-85 (c) \\
\hline $\begin{array}{l}\text { Traceability to NIST gas } \\
\text { standard }\end{array}$ & $\begin{array}{l}\text { Methanol in air gases- States that Methanol in air gases used for response } \\
\text { factor determination in hydrocarbon analyzers in Evaporative Emission Test } \\
\text { Procedures for New (in this case } 1985 \text { and newer, until superseded) Gasoline- } \\
\text { Fueled, Natural Gas- Fueled, Liquefied Petroleum Gas-Fueled and Methanol- } \\
\text { Fueled Heavy-Duty Vehicles "shall be traceable to within } \pm 2 \text { percent of NIST } \\
\text { (formerly NBS) gas standards, or other gas standards which have been approved } \\
\text { by the Administrator." This requirement is defined for control of emissions } \\
\text { from new and in-use highway vehicles and engines. }\end{array}$ & EPA & 40 CFR 86.1214-85 (d)(2) \\
\hline Traceability & $\begin{array}{l}\text { FID Response Factor Methane -States that "When the FID analyzer to be used } \\
\text { for the analysis of natural gas-fueled vehicle hydrocarbon samples has been } \\
\text { calibrated using propane, the methane response factor of the analyzer shall be } \\
\text { established. To determine the total hydrocarbon FID response to methane, } \\
\text { known methane in air concentrations traceable to National Institute of Standards } \\
\text { and Technology (NIST) shall be analyzed by the FID. " This is required for } \\
\text { calibration of hydrocarbon analyzers used in Evaporative Emission Test } \\
\text { Procedures for New (in this case, } 1990 \text { and newer until superseded) Gasoline- } \\
\text { Fueled, Natural Gas- Fueled, Liquefied Petroleum Gas-Fueled and Methanol- } \\
\text { Fueled Heavy-Duty Vehicles as part of control of emissions from new and in- } \\
\text { use highway vehicles and engines. }\end{array}$ & EPA & 40 CFR 86.1221-90 (e) \\
\hline
\end{tabular}




\begin{tabular}{|c|c|c|c|}
\hline $\begin{array}{l}\text { NIST Traceable standards for } \\
\text { calibration }\end{array}$ & $\begin{array}{l}\text { Calibration- This regulation states that an application for approval of an alternate } \\
\text { test system that would consistently and reliably produce emission test results } \\
\text { that are at least equivalent to those described in 40CFR 86.1306-07 (Emission } \\
\text { Regulations for New Otto-Cycle and Diesel Heavy-Duty Engines; Gaseous and } \\
\text { Particulate Exhaust Test Procedures) should include a section that "shall } \\
\text { describe all of the installation, calibration, operation, and maintenance } \\
\text { procedures in a step-by-step format. Note that empirical calibration with respect } \\
\text { to another prescribed or approved measurement system is not acceptable. } \\
\text { Calibration should be performed with NIST traceable standards, or equivalent } \\
\text { national standards". }\end{array}$ & EPA & $\begin{array}{l}40 \text { CFR } 86.1306- \\
07(d)(5)(\text { iii) }\end{array}$ \\
\hline $\begin{array}{l}\text { NIST Traceable standards for } \\
\text { calibration }\end{array}$ & $\begin{array}{l}\text { Calibration- This regulation states that for an application for approval of an } \\
\text { alternate test system that would consistently and reliably produce emission test } \\
\text { results that are at least equivalent to those described in 40CFR 86.1306-07 } \\
\text { (Emission Regulations for New Otto-Cycle and Diesel Heavy-Duty Engines; } \\
\text { Gaseous and Particulate Exhaust Test Procedures) comparison of results from } \\
\text { the alternate system and from the prescribed system (or other system approved } \\
\text { by the Administrator) need to be included. "The two systems must be calibrated } \\
\text { independently to NIST traceable standards or equivalent national standards for } \\
\text { this comparison."...... }\end{array}$ & EPA & $\begin{array}{l}40 \text { CFR 86.1306- } \\
07(d)(5)(\text { iv) }\end{array}$ \\
\hline $\begin{array}{l}\text { Traceability / calibration - } \\
\text { NBS "true" value }\end{array}$ & $\begin{array}{l}\text { Reference is part of the dynamometer and engine equipment specification for } \\
\text { gaseous and particulate exhaust test procedures used in emission regulations for } \\
\text { new (in this case } 1984 \text { and newer, until superseded) Otto cycle and diesel heavy- } \\
\text { duty engines as part of testing for control of emissions from new and in-use } \\
\text { highway vehicles and engines. Requires that "Engine flywheel torque readout } \\
\text { shall be accurate to within } \pm 3 \text { percent of the NBS "true" value torque", or certain } \\
\text { other defined accuracies. }\end{array}$ & EPA & 40 CFR 86.1308-84 (a)(2) \\
\hline $\begin{array}{l}\text { Traceability / calibration - } \\
\text { NBS "true" value }\end{array}$ & $\begin{array}{l}\text { Reference is part of the dynamometer and engine equipment specification for } \\
\text { gaseous and particulate exhaust test procedures used in emission regulations for } \\
\text { new (in this case } 1984 \text { and newer, until superseded) Otto cycle and diesel heavy- } \\
\text { duty engines as part of testing for control of emissions from new and in-use } \\
\text { highway vehicles and engines. States that "Engine flywheel torque values used } \\
\text { for cycle evaluation shall be accurate to within } \pm 3.6 \text { percent of NBS "true" } \\
\text { values...." to provide a more convenient option for the test procedures. }\end{array}$ & & 40 CFR $86.1308-84$ (c)(2) \\
\hline Traceability & $\begin{array}{l}\text { Weights traceable to NIST - Refers to NBS traceable weights to define to define } \\
\text { the NBS "true" value torque referred to in } 41 \text { CFR } 86.1308-84 \text { para (a)(2) and } \\
\text { para (c)(2). }\end{array}$ & EPA & 40 CFR 86.1308-84 (e) \\
\hline
\end{tabular}




\begin{tabular}{|c|c|c|c|}
\hline $\begin{array}{l}\text { Traceability to NBS weight } \\
\text { standards }\end{array}$ & $\begin{array}{l}\text { Requires that calibration weights used for each range of torque measuring device } \\
\text { be "traceable to NBS weights" in dynamometer and engine equipment } \\
\text { specification for gaseous and particulate exhaust test procedures used in } \\
\text { emission regulations for new (in this case } 1984 \text { and newer, until superseded) } \\
\text { Otto cycle and diesel heavy-duty engines as part of testing for control of } \\
\text { emissions from new and in-use highway vehicles and engines. }\end{array}$ & EPA & $\begin{array}{l}\text { 40CFR 86.1308-84 } \\
\text { (e)(1)(i) }\end{array}$ \\
\hline Traceability to NIST & $\begin{array}{l}\text { Requires that "dewpoint shall be measured with an instrument that exhibits an } \\
\text { accuracy of at least } \pm 0.25^{\circ} \mathrm{C} \text { NIST traceable as stated by the instrument } \\
\text { manufacturer" for establishing ambient conditions for filter stabilization and } \\
\text { weighing; as a requirement for Filter stabilization and microbalance workstation } \\
\text { environmental conditions, microbalance specifications, and particulate matter } \\
\text { filter handling and weighing procedures as part of the gaseous and particulate } \\
\text { exhaust test procedures for emission regulations for new Otto-Cycle and Diesel } \\
\text { heavy-duty engines. }\end{array}$ & EPA & $\begin{array}{l}40 \text { CFR 86.1312- } \\
2007(a)(1)(i)\end{array}$ \\
\hline Traceability to NIST & $\begin{array}{l}\text { Requires that "dewpoint shall be measured with an instrument that exhibits an } \\
\text { accuracy of at least } \pm 0.25^{\circ} \mathrm{C} \text { NIST traceable as stated by the instrument } \\
\text { manufacturer" for verifying the immediate microbalance work environment; as a } \\
\text { requirement for Filter stabilization and microbalance workstation environmental } \\
\text { conditions, microbalance specifications, and particulate matter filter handling } \\
\text { and weighing procedures as part of the gaseous and particulate exhaust test } \\
\text { procedures for emission regulations for new Otto-Cycle and Diesel heavy-duty } \\
\text { engines. }\end{array}$ & EPA & $\begin{array}{l}40 \text { CFR } 86.1312- \\
2007(a)(1)(i i)\end{array}$ \\
\hline Traceability/calibration & $\begin{array}{l}\text { certification and calibration procedures - Specifications for microbalances used } \\
\text { for determination of the weight of filters requires that "all certification and } \\
\text { calibration procedures shall be NIST traceable, or traceable to an equivalent } \\
\text { national standard"; as a requirement for Filter stabilization and microbalance } \\
\text { workstation environmental conditions, microbalance specifications, and } \\
\text { particulate matter filter handling and weighing procedures as part of the gaseous } \\
\text { and particulate exhaust test procedures for emission regulations for new Otto- } \\
\text { Cycle and Diesel heavy-duty engines. }\end{array}$ & EPA & 40 CFR 86.1312-2007(b) \\
\hline $\begin{array}{l}\text { Traceability to NBS gas } \\
\text { standards }\end{array}$ & $\begin{array}{l}\text { Calibration gases - Requires that calibration gases used in gas analyzers for } \\
\text { gaseous and particulate exhaust test procedures used in emission regulations for } \\
\text { new (in this case } 1984 \text { and newer, until superseded) Otto cycle and diesel heavy- } \\
\text { duty engines as part of testing for control of emissions from new and in-use } \\
\text { highway vehicles and engines "shall be accurate to within } \pm 1 \text { percent of NBS } \\
\text { gas standards, or other gas standards which have been approved by the } \\
\text { Administrator" }\end{array}$ & EPA & $\begin{array}{l}40 \text { CFR } 86.1314-84 \\
\text { (f))(2) }\end{array}$ \\
\hline
\end{tabular}

Appendix 22 


\begin{tabular}{|c|c|c|c|}
\hline $\begin{array}{l}\text { Traceability to NBS gas } \\
\text { standards }\end{array}$ & $\begin{array}{l}\text { Span Gases - Requires that span gases used in gas analyzers for gaseous and } \\
\text { particulate exhaust test procedures used in emission regulations for new (in this } \\
\text { case } 1984 \text { and newer, until superseded) Otto cycle and diesel heavy-duty engines } \\
\text { as part of testing for control of emissions from new and in-use highway vehicles } \\
\text { and engines "shall be accurate to within } \pm 2 \text { percent of NBS gas standards, or } \\
\text { other gas standards which have been approved by the Administrator" }\end{array}$ & EPA & 40 CFR 86.1314-84(f)(3) \\
\hline $\begin{array}{l}\text { Traceability to NBS gas } \\
\text { standards }\end{array}$ & $\begin{array}{l}\text { States that "the use of precision blending devices (gas dividers) to obtain the } \\
\text { required calibration gas concentrations is acceptable, provided that the blended } \\
\text { gases are accurate to within } \pm 1.5 \text { percent of NBS gas standards, or other gas } \\
\text { standards which have been approved by the Administrator. This accuracy } \\
\text { implies that primary gases used for blending must be "named" to an accuracy of } \\
\text { at least } \pm 1 \text { percent, traceable to NBS or other approved gas standards." This is } \\
\text { for use in gas analyzers for gaseous and particulate exhaust test procedures used } \\
\text { in emission regulations for new (in this case } 1984 \text { and newer, until superseded) } \\
\text { Otto cycle and diesel heavy-duty engines as part of testing for control of } \\
\text { emissions from new and in-use highway vehicles and engines }\end{array}$ & EPA & 40 CFR 86.1314-84 (g) \\
\hline $\begin{array}{l}\text { Traceability to NIST gas } \\
\text { standard }\end{array}$ & $\begin{array}{l}\text { Calibration gases -Requires that calibration gases used in gas analyzers for } \\
\text { gaseous and particulate exhaust test procedures used in emission regulations for } \\
\text { new (in this case } 1994 \text { and newer, until superseded) Otto cycle and diesel heavy- } \\
\text { duty engines as part of testing for control of emissions from new and in-use } \\
\text { highway vehicles and engines (not including methanol) shall be traceable to } \\
\text { within one percent of NIST (formerly NBS) gas standards, or other gas } \\
\text { standards which have been approved by the Administrator. }\end{array}$ & EPA & 40 CFR 86.1314-94(g)(2) \\
\hline $\begin{array}{l}\text { Traceability to NIST gas } \\
\text { standard }\end{array}$ & $\begin{array}{l}\text { Span gases - Requires that span gases (not including methanol) used in gas } \\
\text { analyzers for gaseous and particulate exhaust test procedures used in emission } \\
\text { regulations for new (in this case } 1994 \text { and newer, until superseded) Otto cycle } \\
\text { and diesel heavy-duty engines as part of testing for control of emissions from } \\
\text { new and in-use highway vehicles and engines "shall be accurate to within two } \\
\text { percent of true concentration, where true concentration refers to NIST (formerly } \\
\text { NBS) gas standards, or other gas standards which have been approved by the } \\
\text { Administrator." }\end{array}$ & EPA & 40 CFR 86.1314-94(g)(3) \\
\hline Traceability & $\begin{array}{l}\text { Methanol in air gases - Requires that Methanol in air gases used for response } \\
\text { factor determination shall be traceable to within } \pm 2 \text { percent of NIST (formerly } \\
\text { NBS) gas standards, or other standards which have been approved by the } \\
\text { Administrator" as part of the gaseous and particulate exhaust test procedures } \\
\text { used in emission regulations for new (in this case } 1994 \text { and newer, until } \\
\text { superseded) Otto cycle and diesel heavy-duty engines in testing for control of } \\
\text { emissions from new and in-use highway vehicles and engines. }\end{array}$ & EPA & $\begin{array}{l}40 \text { CFR } 86.1314- \\
94(\mathrm{~g})(4)(\mathrm{i})\end{array}$ \\
\hline
\end{tabular}




\begin{tabular}{|c|c|c|c|}
\hline $\begin{array}{l}\text { Traceability to NIST/NBS gas } \\
\text { standards }\end{array}$ & $\begin{array}{l}\text { known methane in air concentrations - States that "the use of precision blending } \\
\text { devices (gas dividers) to obtain the required calibration gas concentrations is } \\
\text { acceptable, provided that the blended gases are accurate to within } \pm 1.5 \text { percent } \\
\text { of NBS gas standards, or other gas standards which have been approved by the } \\
\text { Administrator. This accuracy implies that primary gases used for blending must } \\
\text { be "named" to an accuracy of at least } \pm 1 \text { percent, traceable to NBS or other } \\
\text { approved gas standards". This is a part of the requirements for gaseous and } \\
\text { particulate exhaust test procedures used in emission regulations for new (in this } \\
\text { case } 1994 \text { and newer, until superseded) Otto cycle and diesel heavy-duty engines } \\
\text { in testing for control of emissions from new and in-use highway vehicles and } \\
\text { engines. }\end{array}$ & EPA & 40 CFR 86.1314-94 \\
\hline $\begin{array}{l}\text { Traceability to } \\
\text { NBS/calibration }\end{array}$ & $\begin{array}{l}\text { CVS calibration - requires that "the CVS is calibrated using an accurate } \\
\text { flowmeter and restrictor valve. The flowmeter calibration shall be traceable to } \\
\text { the NBS, and will serve as the reference value (NBS "true" value) for the CVS } \\
\text { calibration. (Note: In no case should an upstream screen or other restriction } \\
\text { which can affect the flow be used ahead of the flowmeter unless calibrated } \\
\text { throughout the flow range with such a device.) The CVS calibration procedures } \\
\text { are designed for use of a "metering venturi" type flowmeter. Large radius or } \\
\text { ASME flow nozzles are considered equivalent if traceable to NBS } \\
\text { measurements. Other measurement systems may be used if shown to be } \\
\text { equivalent under the test conditions in this action and traceable to NBS } \\
\text { measurements." This is a part of the requirements for gaseous and particulate } \\
\text { exhaust test procedures used in emission regulations for new (in this case } 1984 \\
\text { and later, until superseded) Otto cycle and diesel heavy-duty engines in testing } \\
\text { for control of emissions from new and in-use highway vehicles and engines. }\end{array}$ & EPA & 40 CFR 86.1319-84(a) \\
\hline Traceability & $\begin{array}{l}\text { Requires that air flow sensor read out tolerances for calibration data } \\
\text { measurements must be } \pm 0.5 \% \text { of NBS "true" value. (MANDATORY if this } \\
\text { technique is used). This measurement is part of the PDP calibration is one of } \\
\text { the required measurements that establishes flow rate of the CVS pump. This is a } \\
\text { part of the requirements for gaseous and particulate exhaust test procedures used } \\
\text { in emission regulations for new (in this case } 1984 \text { and later, until superseded) } \\
\text { Otto cycle and diesel heavy-duty engines in testing for control of emissions from } \\
\text { new and in-use highway vehicles and engines. }\end{array}$ & & 40 CFR 86.1319-84(c)(4) \\
\hline
\end{tabular}




\begin{tabular}{|c|c|c|c|}
\hline Traceability / calibration & $\begin{array}{l}\text { CVS calibration - requires that "the CVS is calibrated using an accurate } \\
\text { flowmeter and restrictor valve. The flowmeter calibration shall be traceable to } \\
\text { the NBS, and will serve as the reference value (NBS "true" value) for the CVS } \\
\text { calibration. The CVS calibration procedures are designed for use of a "metering } \\
\text { venturi" type flowmeter. Large radius or ASME flow nozzles are considered } \\
\text { equivalent if traceable to NBS measurements. Other measurement systems may } \\
\text { be used if shown to be equivalent under the test conditions in this section and } \\
\text { traceable to NBS measurements. Measurements of the various flowmeter } \\
\text { parameters are recorded and related to flow through the CVS. Procedures used } \\
\text { by EPA for both PDP-CVS and CFV-CVS are outlined below. Other } \\
\text { procedures yielding equivalent results may be used if approved in advance by } \\
\text { the Administrator". This is a part of the requirements for gaseous and particulate } \\
\text { exhaust test procedures used in emission regulations for new (in this case } 1990 \\
\text { and later, until superseded) Otto cycle and diesel heavy-duty engines in testing } \\
\text { for control of emissions from new and in-use highway vehicles and engines. }\end{array}$ & EPA & 40 CFR 86.1319-90(a) \\
\hline Traceability / calibration & $\begin{array}{l}\text { Requires that air flow sensor read out tolerances for calibration data } \\
\text { measurements must be } \pm 0.5 \% \text { of NBS "true" value. (MANDATORY if this } \\
\text { technique is used). This measurement is part of the PDP calibration is one of } \\
\text { the required measurements that establishes flow rate of the CVS pump. This is a } \\
\text { part of the requirements for gaseous and particulate exhaust test procedures used } \\
\text { in emission regulations for new (in this case } 1990 \text { and later, until superseded) } \\
\text { Otto cycle and diesel heavy-duty engines in testing for control of emissions from } \\
\text { new and in-use highway vehicles and engines. }\end{array}$ & EPA & 40 CFR 86.1319-90(c)(4) \\
\hline Traceability & $\begin{array}{l}\text { Requires that air flow sensor read out tolerances for flow calibration } \\
\text { measurements must be } \pm 0.5 \% \text { of NBS "true" value. (MANDATORY). This } \\
\text { measurement is part of the CFV calibration is one of the required measurements } \\
\text { that establishes the value of the calibration coefficient at measured values of } \\
\text { pressure, temperature and air flow. This is a part of the requirements for gaseous } \\
\text { and particulate exhaust test procedures used in emission regulations for new (in } \\
\text { this case } 1990 \text { and later, until superseded) Otto cycle and diesel heavy-duty } \\
\text { engines in testing for control of emissions from new and in-use highway } \\
\text { vehicles and engines. }\end{array}$ & & 40 CFR 86.1319-90(d)(3) \\
\hline
\end{tabular}




\begin{tabular}{|c|c|c|c|}
\hline Traceability / calibration & $\begin{array}{l}\text { NBS traceable flow calibration- Requires the use of gas meters or flow } \\
\text { instrumentation to determine flow through the particulate filters, methanol } \\
\text { impingers and formaldehyde impingers while sampling for particulate, methanol } \\
\text { and formaldehyde emissions as part of Gaseous and Particulate Exhaust Test } \\
\text { Procedures for Emission Regulations for New (in this case } 1990 \text { and later, until } \\
\text { superseded) Otto-Cycle and Diesel Heavy-Duty Engines. The regulation states } \\
\text { that the instruments shall be calibrated initially and periodically by installing a } \\
\text { "calibration device in series with the instrument. A critical flow orifice, a } \\
\text { bellmouth nozzle, or a laminar flow element or an NBS traceable flow } \\
\text { calibration device is required as the standard device". This regulation covers } \\
\text { testing for control of emissions from new and in-use highway vehicles and } \\
\text { engines. }\end{array}$ & EPA & $\begin{array}{l}40 \text { CFR } 86.1320-90 \\
\text { (a)(1)(i) }\end{array}$ \\
\hline Traceability & $\begin{array}{l}\text { known methane in air concentrations - States that "when the FID analyzer is to } \\
\text { be used for the analysis of natural gas-fueled vehicle hydrocarbon samples, the } \\
\text { methane response factor of the analyzer shall be established. To determine the } \\
\text { total hydrocarbon FID response to methane, known methane in air } \\
\text { concentrations traceable to National Institute of Standards and Technology } \\
\text { (NIST) shall be analyzed by the FID" (MANDATORY). This is required for } \\
\text { calibration of the hydrocarbon analyzer for gaseous and particulate exhaust test } \\
\text { procedures used for emission regulations for new Otto-Cycle and diesel heavy- } \\
\text { duty engines used for control of emissions from new and in-use highway } \\
\text { vehicles and engines. }\end{array}$ & EPA & 40 CFR 86.1321-94(d) \\
\hline Traceability & $\begin{array}{l}\text { Dynamometer specifications and calibration weights as stated under Emission } \\
\text { Test Equipment Provisions for control of emissions from new and in-use } \\
\text { nonroad compression-ignition engines require that "a minimum of six calibration } \\
\text { weights for each range used are required. The weights must be spaced to reflect } \\
\text { good engineering judgment such that they cover the range of weights required } \\
\text { and must be traceable to within } 0.5 \text { percent of NIST weights. Laboratories } \\
\text { located in foreign countries may certify calibration weights to local government } \\
\text { bureau standards." }\end{array}$ & EPA & 40 CFR 89.306(b) \\
\hline Traceability/calibration & $\begin{array}{l}\text { Requires that "calibration gas values are to be derived from NIST Standard } \\
\text { Reference Materials (SRMs) or other standardized gas samples...". This } \\
\text { requirement for analytical gases is stated under the emissions test equipment } \\
\text { provisions for control of emissions from new and in-use nonroad compression- } \\
\text { ignition engines. }\end{array}$ & EPA & 40 CFR 89.312(c)(1) \\
\hline
\end{tabular}




\begin{tabular}{|c|c|c|c|}
\hline Traceability/calibration & $\begin{array}{l}\text { Requires that "The true concentration of a span gas must be within } \pm 2 \text { percent of } \\
\text { the NIST gas standard. The true concentration of a calibration gas must be } \\
\text { within } \pm 1 \text { percent of the NIST gas standard. The use of precision blending } \\
\text { devices (gas dividers) to obtain the required calibration gas concentrations is } \\
\text { acceptable, provided that the blended gases are accurate to within } \pm 1.5 \text { percent } \\
\text { of NIST gas standards, or other gas standards which have been approved by the } \\
\text { Administrator. This accuracy implies that primary gases used (or blending) must } \\
\text { be "named" to an accuracy of at least } \pm 1 \text { percent, traceable to NIST or other } \\
\text { approved gas standards. All concentrations of calibration gas shall be given on a } \\
\text { volume basis (volume percent or volume ppm)." This requirement for analytical } \\
\text { gases is stated under the emissions test equipment provisions for control of } \\
\text { emissions from new and in-use nonroad compression-ignition engines. }\end{array}$ & EPA & 40 CFR 89.312(c)(1) \\
\hline Traceability/calibration & $\begin{array}{l}\text { States that "the CVS is calibrated using an accurate flowmeter and restrictor } \\
\text { valve where the flowmeter calibration must be traceable to NIST measurements, } \\
\text { and will serve as the reference value (NIST "true" value) for the CVS } \\
\text { calibration". This requirement is for CVS calibrations for dilute sampling } \\
\text { procedures stated for test procedures for exhaust emissions in testing for control } \\
\text { of emissions from new and in-use nonroad compression-ignition engines. }\end{array}$ & EPA & 40 CFR89.422(a)(1) \\
\hline Traceability & $\begin{array}{l}\text { States that "The CVS calibration procedures are designed for use of a "metering } \\
\text { venturi" type flowmeter. Large radius or ASME flow nozzles are considered } \\
\text { equivalent if traceable to NIST measurements. Other measurement systems may } \\
\text { be used if shown to be equivalent under the test conditions in this section and } \\
\text { traceable to NIST measurements." This requirement is for CVS calibrations for } \\
\text { dilute sampling procedures stated for test procedures for exhaust emissions in } \\
\text { testing for control of emissions from new and in-use nonroad compression- } \\
\text { ignition engines. }\end{array}$ & EPA & 40 CFR89.422(a)(2) \\
\hline Traceability & $\begin{array}{l}\text { Requires that air flow sensor read out tolerances for calibration data } \\
\text { measurements must be } \pm 0.5 \% \text { of NBS "true" value. (MANDATORY if this } \\
\text { technique is used). This measurement is part of the PDP calibration is one of the } \\
\text { required measurements that establishes flow rate of the CVS pump. This } \\
\text { requirement is for CVS calibrations for dilute sampling procedures used for test } \\
\text { procedures for exhaust emissions in testing for control of emissions from new } \\
\text { and in-use nonroad compression-ignition engines. }\end{array}$ & EPA & 40 CFR89.422(c)(4) \\
\hline Traceability/calibration & $\begin{array}{l}\text { The regulation states that to ensure dynamometer calibration accuracy a } \\
\text { minimum of three calibration weights for each range used is required. The } \\
\text { weights must be equally spaced and traceable to within } 0.5 \text { percent of National } \\
\text { Institute for Standards and Testing (NIST) weights. Laboratories located in } \\
\text { foreign countries may certify calibration weights to local government bureau } \\
\text { standards". This regulation is included in the emission test equipment provisions } \\
\text { for control of emissions from nonroad spark-ignition engines at or below } 19 \mathrm{~kW} \text {. }\end{array}$ & EPA & 40 CFR90.305(b)(2) \\
\hline
\end{tabular}

Appendix 22 


\begin{tabular}{|c|c|c|c|}
\hline SRMs & $\begin{array}{l}\text { Requires that "calibration gas values are to be derived from NIST "Standard } \\
\text { Reference Materials" (SRMs) and are to be single blends as specified.." This } \\
\text { requirement for analytical gases is included in the emission test equipment } \\
\text { provisions for control of emissions from nonroad spark-ignition engines at or } \\
\text { below 19kW. }\end{array}$ & EPA & 40 CFR $90.312(c)(1)$ \\
\hline SRMs & $\begin{array}{l}\text { This regulation states that "the true concentration of a span gas must be within } \pm \\
\text { two percent of the NIST gas standard. The true concentration of a calibration gas } \\
\text { must be within } \pm \text { one percent of the NIST gas standard". This requirement for } \\
\text { analytical gases is included in the emission test equipment provisions for control } \\
\text { of emissions from nonraod spark-ignition engines at or below } 19 \mathrm{~kW} \text {. }\end{array}$ & EPA & 40 CFR 90.312(c)(3) \\
\hline Traceability/calibration/SRMs & $\begin{array}{l}\text { Specifies accuracy requirements for divider gases, if used, as part of emission } \\
\text { test equipment provisions for control of emissions from nonroad spark-ignition } \\
\text { engines at or below 19kW. The regulations states that "the use of precision } \\
\text { blending devices (gas dividers) to obtain the required calibration gas } \\
\text { concentrations is acceptable, provided that the blended gases are accurate to } \\
\text { within } \pm 1.5 \text { percent of NIST gas standards or other gas standards which have } \\
\text { been approved by the Administrator. This accuracy implies that primary gases } \\
\text { used for blending must be "named" to an accuracy of at least } \pm \text { one percent, } \\
\text { traceable to NIST or other approved gas standards". }\end{array}$ & EPA & 40 CFR90.314(c)(Note) \\
\hline Traceability/SRMs & $\begin{array}{l}\text { Specifies requirements for span gases, if used, as part of emission test equipment } \\
\text { provisions for control of emissions from nonroad spark-ignition engines at or } \\
\text { below } 19 \mathrm{~kW} \text {. States that "The span gases must be accurate to within } \pm \text { two } \\
\text { percent of NIST gas standards or other gas standards which have been approved } \\
\text { by the Administrator.". }\end{array}$ & EPA & 40 CFR90.314(c)(i) \\
\hline SRMs & $\begin{array}{l}\text { Specifies requirements for calibration gases, as part of emission test equipment } \\
\text { provisions for control of emissions from nonroad spark-ignition engines at or } \\
\text { below } 19 \mathrm{~kW} \text {. Requires the selection of "a calibration gas (a span gas may be } \\
\text { used for calibrating the CO } 2 \text { analyzer) with a concentration between the two } \\
\text { lowest non-zero gas divider increments. This gas must be "named" to an } \\
\text { accuracy of } \pm \text { one percent of NIST gas standards or other standards approved by } \\
\text { the Administrator". }\end{array}$ & EPA & 40 CFR90.314(c) \\
\hline Traceability/calibration & $\begin{array}{l}\text { States that for diluting sampling procedures used in gaseous exhaust test } \\
\text { procedures for control of emissions from nonroad spark-ignition engines at or } \\
\text { below } 19 \mathrm{~kW} \text {, the CVS has to be calibrated using an accurate flowmeter and } \\
\text { restrictor valve. The "flowmeter calibration must be traceable to the National } \\
\text { Institute for Standards and Testing (NIST) and serves as the reference value } \\
\text { (NIST "true" value) for the CVS calibration" (MANDATORY). }\end{array}$ & EPA & 40 CFR90.424(a)(1) \\
\hline
\end{tabular}




\begin{tabular}{|c|c|c|c|}
\hline Traceability/calibration & $\begin{array}{l}\text { States that for diluting sampling procedures used in gaseous exhaust test } \\
\text { procedures for control of emissions from nonroad spark-ignition engines at or } \\
\text { below } 19 \mathrm{~kW} \text {, the CVS has to be calibrated using an accurate flowmeter and } \\
\text { restrictor valve. The regulation states that "large radius or American Society of } \\
\text { Mechanical Engineers (ASME) flow nozzles are considered equivalent if } \\
\text { traceable to NIST measurements. Other measurement systems may be used if } \\
\text { shown to be equivalent under the test conditions in the section and traceable to } \\
\text { NIST measurements". }\end{array}$ & EPA & 40 CFR 90.424(a)(2) \\
\hline Traceability/calibration & $\begin{array}{l}\text { Regulation requires that sensor-readout tolerances for airflow during calibration } \\
\text { data measurements must be } \pm 0.5 \text { percent of NIST value (MANDATORY). This } \\
\text { measurement is part of the test configuration required to establish the flow rate } \\
\text { of the CVS pump for PDP-CVS calibration for diluting sampling procedures } \\
\text { used in gaseous exhaust test procedures for control of emissions from nonroad } \\
\text { spark-ignition engines at or below } 19 \mathrm{~kW} \text {. }\end{array}$ & EPA & 40 CFR 90.424(c)(4) \\
\hline Traceability/calibration & $\begin{array}{l}\text { Regulation requires that sensor-readout tolerances for airflow during calibration } \\
\text { data measurements must be } \pm 0.5 \text { percent of NIST value (MANDATORY). This } \\
\text { measurement is part of the test configuration required for flow calibration as part } \\
\text { of the CFV-CVS calibration for diluting sampling procedures used in gaseous } \\
\text { exhaust test procedures for control of emissions from nonroad spark-ignition } \\
\text { engines at or below } 19 \mathrm{~kW} \text {. }\end{array}$ & EPA & 40 CFR 90.424(c)(4) \\
\hline Traceability & $\begin{array}{l}\text { The dynamometers specifications and calibration accuracy requirements stated } \\
\text { as part of the emissions test provisions for control of emissions from marine } \\
\text { spark- ignition engines require that "a minimum of three calibration weights for } \\
\text { each range used is required. The weights must be equally spaced and traceable to } \\
\text { within } 0.5 \text { percent of National Institute of Standards and Testing (NIST) } \\
\text { weights. Laboratories located in foreign countries may certify calibration } \\
\text { weights to local government bureau standards". }\end{array}$ & EPA & 40 CFR 91.305(b)(2) \\
\hline SRM & $\begin{array}{l}\text { This regulation states that for calibration gases used in emission test equipment } \\
\text { for control of emissions from marine spark-ignition engines, the "calibration gas } \\
\text { values are to be derived from NIST "Standard Reference Materials" (SRMs) or } \\
\text { other local gas standards and are to be single blends as specified...". }\end{array}$ & EPA & 40 CFR 91.312(c)(1) \\
\hline SRM & $\begin{array}{l}\text { This regulation states that for calibration gases used in emission test equipment } \\
\text { for control of emissions from marine spark-ignition engines, that "the true } \\
\text { concentration of a span gas must be within } \pm 2 \text { percent of the NIST gas standard. } \\
\text { The true concentration of a calibration gas must be within } \pm 1 \text { percent of the } \\
\text { NIST gas standard" (MANDATORY). }\end{array}$ & EPA & 40 CFR 91.312(c)(3) \\
\hline
\end{tabular}




\begin{tabular}{|c|c|c|c|}
\hline Traceability to SRM & $\begin{array}{l}\text { This reference pertains to calibration of emission measurement equipment using } \\
\text { bag sampling techniques, when emissions are below } 15 \% \text { of the full scale } \\
\text { reading. The regulation states emissions test equipment provisions for control of } \\
\text { emissions from marine spark-ignition engines. The reference states that "the use } \\
\text { of precision blending devices (gas dividers) to obtain the required calibration gas } \\
\text { concentrations is acceptable, provided that the blended gases are accurate to } \\
\text { within } \pm 1.5 \text { percent of NIST gas standards or other gas standards which have } \\
\text { been approved by the Administrator. This accuracy implies that primary gases } \\
\text { used for blending must be "named" to an accuracy of at least } \pm 1 \text { percent, } \\
\text { traceable to NIST or other approved gas standards". }\end{array}$ & EPA & 40 CFR 91.314(c)(2) \\
\hline Traceability to SRM & $\begin{array}{l}\text { This regulation states that when span gases are used in analyzers for emissions } \\
\text { testing for control of emissions from marine spark-ignition engines the } \\
\text { procedure used should "span the full analyzer range using a top range calibration } \\
\text { gas. The span gases must be accurate to within } \pm 2 \text { percent of NIST gas } \\
\text { standards or other gas standards which have been approved by the } \\
\text { Administrator". }\end{array}$ & EPA & 40 CFR 91.314(c)(2)(i) \\
\hline Traceability to SRM & $\begin{array}{l}\text { As per this regulation, when calibrating an analyzer for emissions testing for } \\
\text { control of emissions from marine spark-ignition engines, "select a calibration } \\
\text { gas (a span gas may be used for calibrating the CO2 analyzer) with a } \\
\text { concentration between the two lowest non-zero gas divider increments. This gas } \\
\text { must be "named" to an accuracy of } \pm 2 \text { percent of NIST gas standards, or other } \\
\text { standards approved by the Administrator". }\end{array}$ & EPA & 40 CFR 91.314(c)(2)(iii) \\
\hline Traceability & $\begin{array}{l}\text { States that for diluting sampling procedures used in gaseous exhaust test } \\
\text { procedures for control of emissions from marine spark-ignition engines, the } \\
\text { CVS has to be calibrated using an accurate flowmeter and restrictor valve. The } \\
\text { "flowmeter calibration shall be traceable to the National Institute for Standards } \\
\text { and Testing (NIST) and will serve as the reference value (NIST "true" value) for } \\
\text { the CVS calibration" (MANDATORY). }\end{array}$ & EPA & 40 CFR 91.424(a)(1) \\
\hline Traceability & $\begin{array}{l}\text { States that for diluting sampling procedures used in gaseous exhaust test } \\
\text { procedures for control of emissions from marine spark-ignition engines, the } \\
\text { CVS has to be calibrated using an accurate flowmeter and restrictor valve. The } \\
\text { regulation states that "large radius or American Society of Mechanical Engineers } \\
\text { (ASME) flow nozzles are considered equivalent if traceable to NIST } \\
\text { measurements. Other measurement systems may be used if shown to be } \\
\text { equivalent under the test conditions in the section and traceable to NIST } \\
\text { measurements". }\end{array}$ & EPA & 40 CFR 91.424(a)(2) \\
\hline
\end{tabular}




\begin{tabular}{|c|c|c|c|}
\hline Traceability & $\begin{array}{l}\text { Regulation requires that sensor-readout tolerances for airflow during calibration } \\
\text { data measurements must be } \pm 0.5 \text { percent of NIST value (MANDATORY). This } \\
\text { measurement is part of the test configuration required to establish the flow rate } \\
\text { of the CVS pump for PDP-CVS calibration for diluting sampling procedures } \\
\text { used in gaseous exhaust test procedures for control of emissions from marine } \\
\text { spark-ignition engines. }\end{array}$ & EPA & 40 CFR 91.424(c)(4) \\
\hline Traceability & $\begin{array}{l}\text { Regulation requires that sensor-readout tolerances for airflow during calibration } \\
\text { data measurements must be } \pm 0.5 \text { percent of NIST value (MANDATORY). This } \\
\text { measurement is part of the test configuration required for flow calibration as part } \\
\text { of the CFV-CVS calibration for diluting sampling procedures used in gaseous } \\
\text { exhaust test procedures for control of emissions from marine spark-ignition } \\
\text { engines. }\end{array}$ & EPA & 40 CFR 91.424(d)(3) \\
\hline Traceability & $\begin{array}{l}\text { Defines accuracy as "the difference between the measured value and the true } \\
\text { value, where the true value is determined from NIST traceable measurements } \\
\text { where possible, or otherwise determined by good engineering practice" }\end{array}$ & EPA & 40 CFR 92.102 \\
\hline Traceability & $\begin{array}{l}\text { This regulation requires that in addition to certain general requirements, for } \\
\text { purposes of engine testing, the engine or dynamometer readout signals for speed } \\
\text { and torque shall also meet the following accuracy specifications, amongst } \\
\text { others:" Engine flywheel torque readout shall be accurate to either within } \pm 3 \\
\text { percent of the NIST "true" value torque, or the following accuracies, whichever } \\
\text { provides the most accurate readout:(A) } \pm 20 \mathrm{ft} .-1 b s \text {. of the NIST "true" value if } \\
\text { the full scale value is } 9000 \mathrm{ft} \text {-lbs. or less. (B) } \pm 30 \mathrm{ft} \text {.-lbs., of the NIST "true" } \\
\text { value if the full scale value is greater than } 9000 \mathrm{ft} \text {-lbs". This specification for } \\
\text { engine testing is defined as a test procedure for control of air pollution from } \\
\text { locomotives and locomotive engines. }\end{array}$ & EPA & 40 CFR 92.106(b)(1)(ii) \\
\hline Traceability/SRM & $\begin{array}{l}\text { As per this regulation, calibration gases used as analytical gases in test } \\
\text { procedures for control of air pollution from locomotives and locomotive } \\
\text { engines, "shall be accurate to within } \pm 1 \text { percent of NIST gas standards, or other } \\
\text { gas standards which have been approved by the Administrator". }\end{array}$ & EPA & 40 CFR 92.112(h)(2) \\
\hline Traceability/SRM & $\begin{array}{l}\text { As per this regulation, span gases used as analytical gases in test procedures for } \\
\text { control of air pollution from locomotives and locomotive engines, "shall be } \\
\text { accurate to within } \pm 2 \text { percent of NIST gas standards, or other gas standards } \\
\text { which have been approved by the Administrator.". }\end{array}$ & EPA & 40 CFR 92.112(h)(3) \\
\hline Traceability/SRM & $\begin{array}{l}\text { As per this regulation, for analytical gases in test procedures for control of air } \\
\text { pollution from locomotives and locomotive engines, "the use of precision } \\
\text { blending devices (gas dividers) to obtain the required calibration gas } \\
\text { concentrations is acceptable, provided that the blended gases are accurate to } \\
\text { within } \pm 1.5 \text { percent of NIST gas standards, or other gas standards which have } \\
\text { been approved by the Administrator. This accuracy implies that primary gases } \\
\text { used for blending must be "named" to an accuracy of at least } \pm 1 \text { percent, } \\
\text { traceable to NIST or other approved gas standards.". }\end{array}$ & EPA & 40 CFR 92.112(j) \\
\hline
\end{tabular}




\begin{tabular}{|c|c|c|c|}
\hline Traceability & $\begin{array}{l}\text { This reference defines NIST "true" value torque for dynamometer equipment } \\
\text { calibration as part of the calibration of engine output measurement system for } \\
\text { test procedures used in control of air pollution from locomotives and locomotive } \\
\text { engines. The NIST "true" value torque is defined as "the torque calculated by } \\
\text { taking the product of an NIST traceable weight or force and a sufficiently } \\
\text { accurate horizontal lever arm distance, corrected for the hanging torque of the } \\
\text { lever arm". }\end{array}$ & EPA & 40 CFR 92.116(b)(1) \\
\hline Traceability & $\begin{array}{l}\text { Regulation specifies the requirement of calibration weights as "a minimum of } \\
\text { six calibration weights for each range of torque measuring device used are } \\
\text { required. The weights must be approximately equally spaced and each must be } \\
\text { traceable to NIST weights within } 0.1 \text { percent. Laboratories located in foreign } \\
\text { countries may certify calibration weights to local government bureau standards. } \\
\text { Certification of weight by state government Bureau of Weights and Measures is } \\
\text { acceptable. Effects of changes in gravitational constant at the test site may be } \\
\text { accounted for if desired." This is used for dynamometer equipment calibration as } \\
\text { part of the calibration of engine output measurement system for test procedures } \\
\text { used in control of air pollution from locomotives and locomotive engines. }\end{array}$ & EPA & $\begin{array}{l}40 \text { CFR } \\
92.116(\mathrm{~b})(1)(\mathrm{i})(\mathrm{A})\end{array}$ \\
\hline Traceability & $\begin{array}{l}\text { States calibration requirements for a master load cell shall be precalibrated or } \\
\text { calibrated with known weights traceable to NIST within } 0.1 \text { percent } \ldots \text { This } \\
\text { requirement is for equipment calibration as part of the calibration of engine } \\
\text { output measurement system for test procedures used in control of air pollution } \\
\text { from locomotives and locomotive engines. }\end{array}$ & EPA & $\begin{array}{l}40 \text { CFR } \\
92.116(\mathrm{~b})(1)(\mathrm{ii})(\mathrm{A})\end{array}$ \\
\hline Traceability & $\begin{array}{l}\text { This regulation requires that the calibration weights used to calibrate the master } \\
\text { load cell and read out system for dynamometer equipment calibration as part of } \\
\text { the calibration of engine output measurement system for test procedures used in } \\
\text { control of air pollution from locomotives and locomotive engines must be } \\
\text { traceable to within } 0.1 \text { percent of NIST weights. (MANDATORY) }\end{array}$ & EPA & 40 CFR 92.116(c)(3)(i) \\
\hline Traceability/calibration & $\begin{array}{l}\text { This regulation requires that for calibration of gas meters or flow instruments } \\
\text { used for particle measurement in test procedures used to control air pollution } \\
\text { from locomotive and locomotive engines, the calibration device should be } \\
\text { installed in series with the instrument. "A critical flow orifice, a bellmouth } \\
\text { nozzle, or a laminar flow element or an NIST traceable flow calibration device is } \\
\text { required as the standard device." (MANDATORY) }\end{array}$ & EPA & 40 CFR 92.117(a)(1)(i) \\
\hline
\end{tabular}

Appendix 22 


\begin{tabular}{|c|c|c|c|}
\hline SRM & $\begin{array}{l}\text { This regulation defines procedures for smoke meter testing and calibration used } \\
\text { in test procedures for control of air pollution from locomotives and locomotive } \\
\text { engines. The regulation specifies that "Calibrated neutral density filters having } \\
\text { approximately } 10,20 \text {, and } 40 \text { percent opacity shall be employed to check the } \\
\text { linearity of the instrument. The filter(s) shall be inserted in the light path } \\
\text { perpendicular to the axis of the beam and adjacent to the opening from which the } \\
\text { beam of light from the light source emanates, and the recorder response shall be } \\
\text { noted. Filters with exposed filtering media should be checked for opacity every } \\
\text { six months; all other filters shall be checked every year, using NIST or } \\
\text { equivalent reference filters". }\end{array}$ & EPA & 40 CFR 92.122(b) \\
\hline Traceability to SRM & $\begin{array}{l}\text { This regulation states that for calibrating exhaust emissions sample analyzers } \\
\text { that will be used for readings below } 15 \% \text { full scale deflection, in order to ensure } \\
\text { accuracy of the calibration curves the calibration procedure should involve } \\
\text { amongst other steps selection of a" calibration gas (a span gas may be used for } \\
\text { calibrating the } \mathrm{CO} 2 \text { analyzer) with a concentration between the two lowest non- } \\
\text { zero gas divider increments. This gas must be "named" to an accuracy of } \pm 1.0 \\
\text { percent ( } \pm 2.0 \text { percent for CO } 2 \text { span gas) of NIST gas standards, or other } \\
\text { standards approved by the Administrator." This is part of the procedure to ensure } \\
\text { emissions measurement accuracy in test procedures used to control air pollution } \\
\text { from locomotives and locomotive engines. }\end{array}$ & EPA & 40 CFR 92.127(b)(1)(iii) \\
\hline Traceability to SRM & $\begin{array}{l}\text { This regulation defines the test procedures for category } 3 \text { marine engines as part } \\
\text { of the test procedures for control of emissions from marine compression-ignition } \\
\text { engines. The regulation states that "standards used for calibration shall be } \\
\text { traceable to NIST standards. (Other national standards may be used if they have } \\
\text { been shown to be equivalent to NIST standards.)".(MANDATORY) }\end{array}$ & EPA & 40 CFR 94.109(a)(5) \\
\hline Traceability & $\begin{array}{l}\text { This regulation defines a stock solution as "a solution containing an analyte that } \\
\text { is prepared using a reference material traceable to EPA, the National Institute of } \\
\text { Science and Technology (NIST), or a source that will attest to the purity and } \\
\text { authenticity of the reference material" in the glossary of definitions and purposes } \\
\text { under the guidelines establishing test procedures for analysis of pollutants, with } \\
\text { particular reference to "Methods for Organic Chemical Analysis of Municipal } \\
\text { and Industrial Wastewater". }\end{array}$ & EPA & 40 CFR 136 App. A (25) \\
\hline Security standards & $\begin{array}{l}\text { security and privacy requirements established by the NIST for electronic data } \\
\text { interchange-This regulation cites security and privacy requirements established } \\
\text { by the National Institute of Standards and Technology (NIST) for electronic data } \\
\text { interchange, and permits the use of electronic signatures on travel documents } \\
\text { under the Agency Travel Accountability Requirements, if the stated regulations } \\
\text { are met. }\end{array}$ & $\begin{array}{l}\text { Public } \\
\text { Contracts and } \\
\text { Property } \\
\text { Management }\end{array}$ & 41 CFR 301-71.3 \\
\hline
\end{tabular}




\begin{tabular}{|c|c|c|c|c|}
\hline NBS publication & $\begin{array}{l}\text { This regulation refers to a NBS publication on computer security guidelines and } \\
\text { states that "When maintained in computerized form, records subject to the } \\
\text { Privacy Act shall be maintained, at a minimum, subject to safeguards based on } \\
\text { those recommended in the National Bureau of Standard's booklet "Computer } \\
\text { Security Guidelines for Implementing the Privacy Act of 1974" (May 30, 1975), } \\
\text { and any supplements thereto, which are adequate and appropriate to assuring the } \\
\text { integrity of records in the system." }\end{array}$ & 1975 & Interior & 43 CFR 2.51(c) \\
\hline NBS FIPS publication & $\begin{array}{l}\text { Reference is made to the NBS FIPS publication as the source of information } \\
\text { regarding a state's identifying code when collecting and monitoring support } \\
\text { payments from non-custodial parents. }\end{array}$ & & HHS & 45 CFR 303.7(c)(7)(iv) \\
\hline NBS FIPS publication & $\begin{array}{l}\text { Reference is made to the NBS FIPS publication as the source of state's } \\
\text { identifying code for purposes of notification to the OCSE of liability for past- } \\
\text { due support. }\end{array}$ & & HHS & 45 CFR 303.72(b)(2)(iv) \\
\hline NBS SP 440 & $\begin{array}{l}\text { This subpart incorporates by reference "The Universal Color Language" and } \\
\text { "The Color Names Dictionary" in Color: Universal Language and Dictionary of } \\
\text { Names, National Bureau of Standards Special Publication } 440 \text { for specifications } \\
\text { pertaining to Buoyant Apparatus for Merchant Vessels to be used as life saving } \\
\text { equipment }\end{array}$ & 1976 & DHS/USCG & 46 CFR 160.010-1 \\
\hline NBS SP 440 & $\begin{array}{l}\text { This subpart incorporates by reference "The Universal Color Language" and } \\
\text { "The Color Names Dictionary" in Color: Universal Language and Dictionary of } \\
\text { Names, National Bureau of Standards Special Publication } 440 \text { for specifications } \\
\text { pertaining to Hand Red Flare Distress Signals to be used as life saving } \\
\text { equipment. }\end{array}$ & 1976 & DHS/USCG & 46 CFR 160.021-1 \\
\hline NBS SP440 & $\begin{array}{l}\text { Reference is made to NBS publication "Color Names Dictionary" to define the } \\
\text { colors in tests for chromaticity of Hand Red Flare Distress Signals to be used as } \\
\text { life saving equipment. }\end{array}$ & 1976 & DHS/USCG & 46CFR 160.021-4(d)(7) \\
\hline Publication SP 440 & $\begin{array}{l}\text { This subpart incorporates by reference "The Color Names Dictionary" in } \\
\text { Color: Universal Language and Dictionary of Names, National Bureau of } \\
\text { Standards Special Publication 440, December 1976, for specifications pertaining } \\
\text { to Floating Orange Smoke Distress Signals ( } 5 \text { Minutes) to be used as lifesaving } \\
\text { equipment }\end{array}$ & 1976 & DHS/USCG & 46 CFR 160.022-1 \\
\hline NBS Report 4792 & $\begin{array}{l}\text { This subpart incorporates by reference "Development of a Laboratory Test for } \\
\text { Evaluation of the Effectiveness of Smoke Signals," National Bureau of } \\
\text { Standards Report 4792, July 1956, for specifications pertaining to Floating } \\
\text { Orange Smoke Distress Signals (5 Minutes) to be used as lifesaving equipment. }\end{array}$ & 1956 & DHS/USCG & 46 CFR 160.022-1 \\
\hline NBS SP 440 & $\begin{array}{l}\text { Reference is made to NBS publication "Color Names Dictionary" (colors 34-39 } \\
\text { and 48-54) to define the specifications for orange color of smoke for Floating } \\
\text { Orange Smoke Distress Signals ( } 5 \text { Minutes) to be used as lifesaving equipment. }\end{array}$ & 1976 & DHS/USCG & 46 CFR 160.022-4 (d)(7) \\
\hline
\end{tabular}




\begin{tabular}{|c|c|c|c|c|}
\hline NBS Report 4792 & $\begin{array}{l}\text { Reference is made to National Bureau of Standards Report No. } 4792 \text { to define } \\
\text { the apparatus to be used for determining the volume and density of smoke in } \\
\text { testing of Floating Orange Smoke Distress Signals ( } 5 \text { Minutes) to be used as } \\
\text { lifesaving equipment. }\end{array}$ & 1956 & DHS/USCG & 46 CFR $160.022-4(d)(8)$ \\
\hline Publication 440 & $\begin{array}{l}\text { This subpart incorporates by reference "The Universal Color Language" and } \\
\text { "The Color Names Dictionary" in Color: Universal Language and Dictionary of } \\
\text { Names, National Bureau of Standards Special Publication 440, Dictionary 1976, } \\
\text { for specifications pertaining to Pistol-Projected Parachute Red Flare Distress } \\
\text { Signals to be used as lifesaving equipment. }\end{array}$ & 1976 & DHS/USCG & 46 CFR 160.024-1 \\
\hline NBS SP440 & $\begin{array}{l}\text { Reference is made to NBS publication "Color Names Dictionary" to define the } \\
\text { colors in tests for chromaticity of Pistol-Projected Parachute Red Flare Distress } \\
\text { Signals to be used as lifesaving equipment. }\end{array}$ & 1976 & DHS/USCG & 46 CFR 160.024-4(d)(4) \\
\hline Publication 440 & $\begin{array}{l}\text { This subpart incorporates by reference "The Universal Color Language" and } \\
\text { "The Color Names Dictionary" in Color: Universal Language and Dictionary of } \\
\text { Names, National Bureau of Standards Special Publication 440, December 1976, } \\
\text { for specifications pertaining to Hand-Held Rocket-Propelled Parachute Red } \\
\text { Flare Distress Signals to be used as life saving equipment. }\end{array}$ & 1976 & DHS/USCG & NBS SP 440 \\
\hline Publication 440 & $\begin{array}{l}\text { This subpart incorporates by reference "The Universal Color Language" and } \\
\text { "The Color Names Dictionary" in Color: Universal Language and Dictionary of } \\
\text { Names, National Bureau of Standards Special Publication 440, December 1976, } \\
\text { for specifications pertaining to Hand Orange Smoke Distress Signals to be used } \\
\text { as life saving equipment. }\end{array}$ & 1976 & DHS/USCG & 46 CFR 160.037-1 \\
\hline Report 4792 & $\begin{array}{l}\text { This subpart incorporates by reference "Development of a Laboratory Test for } \\
\text { Evaluation of the Effectiveness of Smoke Signals," National Bureau of } \\
\text { Standards Report } 4792 \text {, July } 1956 \text { for specifications pertaining to Hand Orange } \\
\text { Smoke Distress Signals to be used as life saving equipment. }\end{array}$ & 1956 & DHS/USCG & 46 CFR 160.037-1 \\
\hline Report 4792 & $\begin{array}{l}\text { This subpart refers to equipment described in "Development of a Laboratory } \\
\text { Test for Evaluation of the Effectiveness of Smoke Signals," National Bureau of } \\
\text { Standards Report } 4792 \text {, July } 1956 \text { for specifications pertaining to the volume } \\
\text { and density of smoke for use in the technical test specifications for testing of } \\
\text { Hand Orange Smoke Distress Signals to be used as life saving equipment. }\end{array}$ & 1956 & DHS/USCG & 46 CFR 160.037-4 \\
\hline $\begin{array}{l}\text { NBS Simplified Practice } \\
\text { Recommendation R178-41 }\end{array}$ & $\begin{array}{l}\text { Reference is made to the publication National Bureau of Standards Simplified } \\
\text { Practice Recommendation: No. R178-41, Packaging of First-aid Unit Dressings } \\
\text { and Treatments, as a source of applicable specifications/publications for first-aid } \\
\text { kits for merchant vessels. }\end{array}$ & & DHS/USCG & 46 CFR 160.041-1 \\
\hline
\end{tabular}




\begin{tabular}{|c|c|c|c|c|}
\hline $\begin{array}{l}\text { NBS Simplified Practice } \\
\text { Recommendation R178-41 }\end{array}$ & $\begin{array}{l}\text { Reference is made to the NBS Simplified Practice Recommendations (R178-41) } \\
\text { for Packaging of First-aid Unit Dressings and Treatments, to define size of a } \\
\text { first-aid kits for merchant vessels to be used as life-saving equipment. }\end{array}$ & & DHS/USCG & 46 CFR 160.041-2 \\
\hline $\begin{array}{l}\text { NBS Simplified Practice } \\
\text { Recommendation R178-42 }\end{array}$ & $\begin{array}{l}\text { Reference is made to the NBS Simplified Practice Recommendations (R178-41) } \\
\text { for Packaging of First-aid Unit Dressings and Treatments, to define the type of } \\
\text { carton (standard commercial unit type) for first-aid kits for merchant vessels to } \\
\text { be used as life-saving equipment. }\end{array}$ & & DHS/USCG & 46 CFR 160.041-4 \\
\hline NBS SP 440 & $\begin{array}{l}\text { This subpart incorporates by reference "The Color Names Dictionary" in } \\
\text { Color: Universal Language and Dictionary of Names, National Bureau of } \\
\text { Standards Special Publication 440, December } 1976 \text { for specifications pertaining } \\
\text { to Floating Orange Smoke Distress Signal (15 minutes) in use as lifesaving } \\
\text { equipment. }\end{array}$ & 1976 & DHS/USCG & 46 CFR 160.057-1(a)(1) \\
\hline NBS Report 4792 & $\begin{array}{l}\text { This subpart incorporates by reference "Development of a Laboratory Test for } \\
\text { Evaluation of the Effectiveness of Smoke Signals," National Bureau of } \\
\text { Standards Report } 4792 \text {, July 1956, for specifications pertaining to Floating } \\
\text { Orange Smoke Distress Signals (15 minutes) in use as lifesaving equipment. }\end{array}$ & 1956 & DHS/USCG & 46 CFR 160.057-1 \\
\hline NBS SP 440 & $\begin{array}{l}\text { Reference is made to NBS publication "Color Names Dictionary" (colors 34-39 } \\
\text { and 48-54) to define the specifications for orange color of smoke for Floating } \\
\text { Orange Smoke Distress Signals ( } 15 \text { Minutes) to be used as lifesaving equipment. }\end{array}$ & 1976 & DHS/USCG & 46 CFR 160.057-4(d)(8) \\
\hline NBS Report 4792 & $\begin{array}{l}\text { Reference is made to National Bureau of Standards Report No. } 4792 \text { to define } \\
\text { the apparatus to be used for determining the volume and density of smoke in } \\
\text { testing of Floating Orange Smoke Distress Signals ( } 15 \text { Minutes) to be used as } \\
\text { lifesaving equipment. }\end{array}$ & 1956 & DHS/USCG & 46 CFR 160.057-4(d)(9) \\
\hline NBS SP 440 & $\begin{array}{l}\text { This subpart incorporates by reference, "The Universal Color Language" and } \\
\text { "The Color Names Dictionary" in Color: Universal Language and Dictionary of } \\
\text { Names, National Bureau of Standards Special Publication 440, for specifications } \\
\text { pertaining to Hybrid Inflatable Personal Flotation Devices in use as life saving } \\
\text { equipment. }\end{array}$ & 1976 & DHS/USCG & 46 CFR 160.077-5 \\
\hline NBS SP 440 & $\begin{array}{l}\text { This subpart incorporates by reference NBS Special Publication } 440 \text { Color: } \\
\text { Universal Language and Dictionary of Names, 1976, for specifications } \\
\text { pertaining to Inflatable Liferafts (SOLAS) in use as lifesaving equipment. }\end{array}$ & 1976 & DHS/USCG & 46 CFR 160.151-5 \\
\hline NBS SP440 & $\begin{array}{l}\text { This regulation refers to NBS SP 440, to define the color of the canopy required } \\
\text { for inflatable liferafts (SOLAS) in use as lifesaving equipment. The particular } \\
\text { color referred to her is color } 34 \text { in SP } 440\end{array}$ & 1976 & DHS/USCG & 46 CFR 160.151-15(e) \\
\hline
\end{tabular}




\begin{tabular}{|c|c|c|c|c|}
\hline NBS SP 440 & $\begin{array}{l}\text { NBS SP } 440 \text { is referred to by the statement that "The primary color of the } \\
\text { appendages must be vivid reddish orange (color number } 34 \text { of NBS Special } \\
\text { Publication } 440 \text { ), or a fluorescent color of a similar hue" to define the } \\
\text { requirements that appendages on inflatable liferafts (SOLAS) should meet to } \\
\text { resist capsizing from winds and waves. }\end{array}$ & 1976 & DHS/USCG & $\begin{array}{l}46 \text { CFR 160.151- } \\
17(a)(2)(\text { vii) }\end{array}$ \\
\hline NBS SP 440 & $\begin{array}{l}\text { This subpart incorporates by reference National Bureau of Standards Special } \\
\text { Publication } 440 \text { - Color, Universal Language and Dictionary of Names; } \\
\text { December 1976, as part of the definition of specification for immersion suits in } \\
\text { use as lifesaving equipment. }\end{array}$ & 1976 & DHS/USCG & 46 CFR 160.171-3 \\
\hline NBS SP 440 & $\begin{array}{l}\text { This subchapter refers to NBS SP } 440 \text { to specify the requirements for the } \\
\text { primary color of the exterior surface of each thermal protective aid ( vivid } \\
\text { reddish orange, color number } 34 \text { of National Bureau of Standards Publication } \\
440 \text { ). This forms part of the requirements for immersion suits used as lifesaving } \\
\text { equipment. }\end{array}$ & 1976 & DHS/USCG & 46 CFR 160.171-9(h) \\
\hline NBS SP 440 & $\begin{array}{l}\text { This subpart incorporates by reference National Bureau of Standards Special } \\
\text { Publication } 440 \text { - Color, Universal Language and Dictionary of Names, for } \\
\text { specifications pertaining to thermal protective aids used as lifesaving equipment. }\end{array}$ & & DHS/USCG & 46 CFR 160.174-3(f) \\
\hline NBS SP 440 & $\begin{array}{l}\text { This subchapter refers to NBS SP } 440 \text { to specify the requirements for the } \\
\text { primary color of the exterior surface of each thermal protective aid ( vivid } \\
\text { reddish orange, color number } 34 \text { of National Bureau of Standards Publication } \\
440 \text { ). This forms part of the requirements for thermal protective aids used as } \\
\text { lifesaving equipment. }\end{array}$ & & DHS/USCG & 46 CFR 160.174-9(h) \\
\hline NBS SP 440 & $\begin{array}{l}\text { This subpart incorporates by reference Special Pub. } 440 \text {, Color: Universal } \\
\text { Language and Dictionary of Names; "The Universal Color Language" and "The } \\
\text { Color Names Dictionary", } 1976-160.176-9 \text {, for specifications pertaining to } \\
\text { inflatable lifejackets in use as lifesaving equipment. }\end{array}$ & & DHS/USCG & 46 CFR 160.176-4 \\
\hline NBS SP440 & $\begin{array}{l}\text { Reference is made to NBS SP } 440 \text { to define the amongst the general features of } \\
\text { inflatable lifejackets, the color on the external surfaces as being "primarily vivid } \\
\text { reddish orange as defined by sections } 13 \text { and } 14 \text { of the "Color Names } \\
\text { Dictionary.." }\end{array}$ & 1976 & DHS/USCG & 46 CFR 160.176-9(a)(10) \\
\hline $\begin{array}{l}\text { NBS Building Materials and } \\
\text { Structures Report } 150\end{array}$ & $\begin{array}{l}\text { Reference is made to the NBS Building Materials and Structures Report } 150 \text { as a } \\
\text { source of fire tests that may be used in addition to the usual fire tests to } \\
\text { determine adequacy of a portable fire extinguisher to be listed and labeled as a } \\
\text { "marine type" extinguisher as part of the requirements for engineering } \\
\text { equipment. }\end{array}$ & & DHS/USCG & 46 CFR 162.028-3(m) \\
\hline NBS Handbook 91 & $\begin{array}{l}\text { This subpart incorporates by reference "Experimental Statistics", National } \\
\text { Bureau of Standards Handbook No. } 91 \text { (October 1966) for specifications } \\
\text { pertaining to pollution prevention equipment. }\end{array}$ & 1966 & DHS/USCG & 46 CFR 162.050-4 \\
\hline
\end{tabular}

\section{Appendix 22}




\begin{tabular}{|c|c|c|c|c|}
\hline NBS Handbook 91 & $\begin{array}{l}\text { Reference is made to NBS Handbook } 91 \text { to define the procedure to be used in } \\
\text { measurements of oil content of samples (containing oil in samples) supplied by } \\
\text { the USCG, for testing pertaining to pollution prevention equipment. }\end{array}$ & & DHS/USCG & 46 CFR $162.050-15(f)(3)$ \\
\hline NBS testing labs & $\begin{array}{l}\text { This section of the subchapter requires that all tests pertaining to deck coverings } \\
\text { have to be conducted at the NBS or other laboratories designated by the Coast } \\
\text { Guard for purposes of inspection and testing of deck coverings for merchant } \\
\text { vessels. }\end{array}$ & & DHS/USCG & 46 CFR 164.006-4(a) \\
\hline NBS testing labs & $\begin{array}{l}\text { Reference is made to the NBS labs as the site of testing materials to be approved } \\
\text { for use as deck covering in merchant vessels. }\end{array}$ & & DHS/USCG & 46 CFR 164.006-5(d) \\
\hline NBS testing labs & $\begin{array}{l}\text { This reference states that all tests and retests pertaining to structural insulations } \\
\text { have to be conducted at the NBS or other laboratories designated by the Coast } \\
\text { Guard. }\end{array}$ & & DHS/USCG & 46 CFR 164.007-4(a) \\
\hline NBS testing labs & $\begin{array}{l}\text { Reference is made to the Fire Research Section of NBS as the site of testing } \\
\text { materials to be approved for use as structural insulations. }\end{array}$ & & DHS/USCG & 46 CFR 164.007-9(c) \\
\hline NBS testing labs & $\begin{array}{l}\text { Reference is made to the NBS or other labs designated by the Coast Guard as the } \\
\text { site for all tests and retests for bulkhead panels. }\end{array}$ & & DHS/USCG & 46 CFR 164.008-3(a) \\
\hline NBS testing labs & $\begin{array}{l}\text { Procedures for testing of materials as bulkhead panels at the Fire Research } \\
\text { Section of NBS, and related administrative procedures are defined. }\end{array}$ & & DHS/USCG & $\begin{array}{l}46 \text { CFR 164.008- } \\
7(\mathrm{c}) \text { and (d) }\end{array}$ \\
\hline NBS SP 440 & $\begin{array}{l}\text { This part incorporates by reference NBS Special Pub. } 440 \text { "Color: Universal } \\
\text { Language and Dictionary of Names", } 1976\end{array}$ & 1976 & DHS/USCG & 46 CFR 169.115(c)(2) \\
\hline Handbook 96 & $\begin{array}{l}\text { Refers to handbook } 96 \text { "Inspection of Processed Photographic Record Films for } \\
\text { Aging Blemishes" to define the procedures to be used for regular inspection of } \\
\text { aging of photographic film and processed photographic film as part of a records } \\
\text { retention schedule. }\end{array}$ & & DOT/MA & 46 CFR 380.21 \\
\hline Accreditation (NVCASE) & $\begin{array}{l}\text { NIST/NVCASE is referred to as the accreditation body of TCBs designated by } \\
\text { the FCC. TCBs can be accredited under the "NVCASE program or other } \\
\text { recognized programs based on ISO/IEC Guide } 65 \text {, to comply with the } \\
\text { Commission's qualification criteria for TCBs". Further per this paragraph "NIST } \\
\text { may, in accordance with its procedures, allow other appropriately qualified } \\
\text { accrediting bodies to accredit TCBs and testing laboratories". }\end{array}$ & & FCC & 47 CFR2.960(b) \\
\hline Accreditation & $\begin{array}{l}\text { The FCC requires TCBs to "participate in any consultative activities, identified } \\
\text { by the Commission or NIST, to facilitate a common understanding and } \\
\text { interpretation of applicable regulations", as part of the requirements for TCBs. }\end{array}$ & & FCC & 47 CFR 2.962(c)(5) \\
\hline Accreditation Of TCBs & $\begin{array}{l}\text { The NIST role in the FCC designation of an organization as a TCB, or } \\
\text { withdrawal of the designation, is recognized. }\end{array}$ & & FCC & 47 CFR 2.962(e) \\
\hline
\end{tabular}




\begin{tabular}{|c|c|c|c|c|}
\hline NBS Technical Note 101 & $\begin{array}{l}\text { In defining the procedure for the Procedure for Calculating PCS Signal Levels at } \\
\text { Microwave Receivers, the PCS to microwave path loss is calculated using a } \\
\text { model derived from the NBS Tech. Note } 101 \text {. This is applicable to cellular } \\
\text { communication station design. }\end{array}$ & $\begin{array}{l}1967 \\
\text { (updated } \\
1982 \\
\text { and } \\
1985)\end{array}$ & FCC & $\begin{array}{l}47 \text { CFR } 24 \text { Appendix I to } \\
\text { Subpart E }\end{array}$ \\
\hline NBS Technical Note 101 & $\begin{array}{l}\text { The propagation model used in the procedure for calculating PCS signal levels at } \\
\text { Microwave receivers is calculated using the Longley-Rice Propagation Model } \\
\text { Version 1.2.2, which in turn is derived from the NBS Technical Note } 101 .\end{array}$ & 1967 & FCC & $\begin{array}{l}47 \text { CFR } 24.253 \text { Appendix } \\
\text { I } 4 .\end{array}$ \\
\hline Accreditation & $\begin{array}{l}\text { Commission will designate as a TCB any organization that meets the } \\
\text { qualification criteria and is accredited by NIST or its recognized accreditor }\end{array}$ & & FCC & 47 CFR68.160 \\
\hline Accreditation (NVCASE) & $\begin{array}{l}\text { TCBs shall be accredited by the NIST under its NVCASE program, or other } \\
\text { recognized programs based on ISO/IEC Guide } 65 \text {, to comply with the } \\
\text { Commission's qualification criteria for TCBs. NIST may, in accordance with its } \\
\text { procedures, allow other appropriately qualified accrediting bodies to accredit } \\
\text { TCBs and testing laboratories. }\end{array}$ & & FCC & 47 CFR68.160 \\
\hline Accreditation & $\begin{array}{l}\text { The FCC requires TCBs to "participate in any consultative activities, identified } \\
\text { by the Commission or NIST, to facilitate a common understanding and } \\
\text { interpretation of applicable regulations" as part of the requirements for TCBs. }\end{array}$ & & FCC & 47 CFR 68.162 (c)(5) \\
\hline Accreditation Of TCBs & $\begin{array}{l}\text { The NIST role in the FCC designation of an organization as a TCB, or } \\
\text { withdrawal of the designation, is recognized. }\end{array}$ & & FCC & 47 CFR 68.162 (e) \\
\hline NBS time signals & $\begin{array}{l}\text { Conditions to be met for rebroadcasting of time signals from the NBS (or the } \\
\text { Naval Observatory and NOAA weather broadcasts) without prior authorization } \\
\text { are stipulated. These rules are applicable to all broadcast stations. }\end{array}$ & & FCC & 47 CFR 73.1207(d)(2) \\
\hline NBS time standards & $\begin{array}{l}\text { The FCC stipulates that "The primary standard of frequency for radio frequency } \\
\text { measurements is the standard frequency maintained by the National Bureau of } \\
\text { Standards or the standard signals of Stations WWV, WWVB, and WWVH of the } \\
\text { National Bureau of Standards". }\end{array}$ & & FCC & 47 CFR 73.1540 \\
\hline $\begin{array}{l}\text { NBS publication (Tech. Note } \\
101)\end{array}$ & $\begin{array}{l}\text { This reference requires the prediction of Power Flux Density (PFD) based on a } \\
\text { point-to-point propagation model by P.L. Rice, A.G. Longley, K.A. Norton, and } \\
\text { A.P. Barsis, "Transmission loss predictions for troposphere communication } \\
\text { circuits", National Bureau of Standards Technical Note 101, Volumes I and II. } \\
\text { This relates to frequency assignment for the purpose of communication in the } \\
821 \mathrm{MHz} \text { to } 824 \mathrm{MHz} \text { and } 866 \mathrm{MHz} \text { to } 869 \mathrm{MHz} \text { frequency bands along the US- } \\
\text { Canada border. }\end{array}$ & & FCC & 47 CFR 90.619(c)(3)(i) \\
\hline Calibration & $\begin{array}{l}\text { The NBS is stated as the source of calibration services for DoE acquisition } \\
\text { officers or its authorized contractors. }\end{array}$ & & DOE & 48 CFR 908.7113 \\
\hline
\end{tabular}




\begin{tabular}{|c|c|c|c|c|}
\hline Handbook H-28 & $\begin{array}{l}\text { NBS Handbook H-28 "Handbook of Screw-Thread Standards for Federal } \\
\text { Services(1957), 1957, December 1966 Edition is incorporated by reference } \\
\text { for this subpart, with references in Title } 49 \text { sections 179.2; 178.45; 178.46. } \\
\text { "National Institute of Standards and Technology, Department of Commerce, } \\
\text { 5285 Port Royal Road, Springfield, VA 22151, USDC" }\end{array}$ & 1957 & DOT/RSPA & 49 CFR 171.7 \\
\hline Handbook H-28 & $\begin{array}{l}\text { Specification for 3T Seamless Steel cylinders requires all opening to be } \\
\text { threaded. The threads (taper and straight) have to be in compliance with the } \\
\text { requirements if NBS Handbook H-28 (mandatory) incorporated by reference }\end{array}$ & 1957 & DOT/RSPA & 49 CFR 178.45(f)(5)ii-iv \\
\hline Handbook H-28 & $\begin{array}{l}\text { Specifications for } 3 \mathrm{AL} \text { seamless aluminum cylinders require that all openings } \\
\text { must be threaded and the threads (tapered or straight) must conform to the } \\
\text { requirements of NBS Handbook H-28 (mandatory) incorporated by reference }\end{array}$ & 1957 & DOT/RSPA & 49 CFR 178.46(e)(5)ii-iv \\
\hline Handbook H-28 & $\begin{array}{l}\text { NBS Handbook H-28 is referred to for defining the abbreviation "NPT" to } \\
\text { "mean an American Standard Taper Pipe Thread conforming to the requirements } \\
\text { of NBS Handbook H-28" for specifications for tank cars (incorporated by } \\
\text { reference) }\end{array}$ & 1957 & DOT/RSPA & 49 CFR 179.2(a)(8) \\
\hline Presumably Handbook 96 & $\begin{array}{l}\text { Reference states that "Film used for photographing copies shall be of permanent } \\
\text { record-type meeting in all respects the minimum specifications of the National } \\
\text { Bureau of Standards, and all processes recommended by the manufacturer shall } \\
\text { be observed to protect it from deterioration or accidental destruction", as part of } \\
\text { the general requirements for copies and records - presumably a reference to NBS } \\
\text { Handbook 96, "Inspection of Processed Photographic Record Films for Aging } \\
\text { Blemishes". }\end{array}$ & & DOT/FMCSA & 49 CFR 390.31(b)(4) \\
\hline NBS FIPS Pub. 1-1 & $\begin{array}{l}\text { Reference is made to the NBS FIPS Publication 1-1which specifies the } \\
\text { information interchange requirements of the ASCII. These information } \\
\text { interchange requirements have to be met by support systems used in conjunction } \\
\text { with automatic on-board recorders used to record a driver's hours of service, to } \\
\text { be capable of providing federal, state or local officials summaries of an } \\
\text { individual driver's hours of service records. }\end{array}$ & & DOT/FMCSA & 49 CFR 395.15(b)(3) \\
\hline NBS 378 & $\begin{array}{l}\text { Requires that oil furnace black (NBS 378) used in the formulation of rubber } \\
\text { compound standard styrene butadiene rubber (SBR) brake cups, should have } \\
\text { properties identical with those supplied by the NBS DOES NOT STATE WHAT } \\
\text { KIND OF NBS PRODUCT (e.g., SRM, RM, etc?) }\end{array}$ & & DOT/NHTSA & 49 CFR 571.116 S7.6 \\
\hline NBS 370 & $\begin{array}{l}\text { Requires that zinc oxide (NBS } 370 \text { )used in the formulation of rubber compound } \\
\text { standard styrene butadiene rubber (SBR) brake cups, should have properties } \\
\text { identical with those supplied by the NBS DOES NOT STATE WHAT KIND OF } \\
\text { NBS PRODUCT (e.g., SRM, RM, etc?) }\end{array}$ & & DOT/NHTSA & 49 CFR 571.116 S7.6 \\
\hline NBS 371 & $\begin{array}{l}\text { Requires that sulfur (NBS 371)used in the formulation of rubber compound } \\
\text { standard styrene butadiene rubber (SBR) brake cups, should have properties } \\
\text { identical with those supplied by the NBS DOES NOT STATE WHAT KIND OF } \\
\text { NBS PRODUCT (e.g., SRM, RM, etc?) }\end{array}$ & & DOT/NHTSA & 49 CFR 571.116 S7.6 \\
\hline
\end{tabular}




\begin{tabular}{|l|l|l|l|} 
NBS 372 & $\begin{array}{l}\text { Requires that stearic acid (NBS 372) used in the formulation of rubber } \\
\text { compound standard styrene butadiene rubber (SBR) brake cups, should have } \\
\text { properties identical with those supplied by the NBS DOES NOT STATE WHAT } \\
\text { KIND OF NBS PRODUCT (e.g., SRM, RM, etc?) }\end{array}$ & $\begin{array}{l}\text { DOT/NHTSA CFR 571.116 S7.6 } \\
\text { Nequires that n-tertiary butyl-2-benzothiazole sulfenamide (NBS 384)used in the } \\
\text { formulation of rubber compound standard styrene butadiene rubber (SBR) brake } \\
\text { cups, should have properties identical with those supplied by the NBS DOES } \\
\text { NOT STATE WHAT KIND OF NBS PRODUCT (e.g., SRM, RM, etc?) }\end{array}$ & DOT/NHTSA 384 \\
\hline
\end{tabular}


Appendix 22 


\section{Appendix 23 \\ Availability of NIST (NBS) Publications}

\begin{tabular}{|c|c|c|}
\hline Product & Availability & Notes: \\
\hline NBS Handbook 28 & Yes & $\begin{array}{l}\text { QC1.U51 (1942, 1944, Supplement in 1949, Supplement in 1950, three parts in } \\
\text { 1957, and supplement in 1963) }\end{array}$ \\
\hline NBS Handbook 69 & Yes & $\begin{array}{l}\text { QC1 .U51 no.69 Title Maximum permissible body burdens and maximum } \\
\text { permissible concentrations of radionuclides in air and in water for occupational } \\
\text { exposure (1959). }\end{array}$ \\
\hline NBS Handbook 81 & Yes & $\begin{array}{l}\text { QC1 .U51 no.81 Title Safety rules for the installation and maintenance of electric } \\
\text { supply and communication lines. Portion of title National electrical safety code }\end{array}$ \\
\hline NBS Handbook 91 & Yes & $\begin{array}{l}\text { QC100 .U565 1966, Mary Gibbons Natrella. Edition Repr. Oct } 1966 \text { with } \\
\text { corrections, revised and updated as "NIST/SEMATECH e-Handbook of } \\
\text { Statistical Methods", http://www.itl.nist.gov/div898/handbook }\end{array}$ \\
\hline NBS Handbook 96 & Yes & $\begin{array}{l}\text { QC1 .U51 no.96 (McCamy, Calvin S.) Title Inspection of processed photographic } \\
\text { record films for aging blemishes (1964) }\end{array}$ \\
\hline NBS Handbook 136 & Yes & $\begin{array}{l}\text { American National Standard N432 : radiological safety for the design and } \\
\text { construction of apparatus for gamma radiography / American National Standards } \\
\text { Institute, Subcommittee N43-3.5, under the sponsorship of the National Bureau of } \\
\text { Standards (1981) }\end{array}$ \\
\hline $\begin{array}{l}\text { NIST Handbook } \\
150\end{array}$ & Yes & $\begin{array}{l}\text { NVLAP procedures and general requirements (James Cigler and Vanda White), } \\
1994 \text { and } 2001\end{array}$ \\
\hline $\begin{array}{l}\text { Weights and } \\
\text { Measures } \\
\text { Handbooks (44, } \\
105-1 \text { and } 133)\end{array}$ & Yes & $\begin{array}{l}\text { Handbooks } 44 \text { and } 133 \text { available at } \\
\text { ( http://ts.nist.gov/ts/htdocs/230/235/pubs.htm ) and Handbook 105-1 } \\
\text { at( http://ts.nist.gov/ts/htdocs/230/235/labmetrologypage.htm ) }\end{array}$ \\
\hline $\begin{array}{l}\text { NIST Special } \\
\text { Publication } 250 \\
\end{array}$ & Yes & $\begin{array}{l}\text { QC100 .U57 no.250 Title NIST calibration services users guide. The National } \\
\text { Institute of Standards and Technology (NIST) Calibration Services Users Guide } \\
\text { provides detailed descriptions of currently available NIST calibration services, } \\
\text { measurement assurance programs, and special test services. The following } \\
\text { measurement areas are covered: (1) dimensional; (2) mechanical, including flow, } \\
\text { acoustic, and ultrasonic; (3) thermodynamic; (4) optical radiation; (5) ionizing } \\
\text { radiation; and (6) electromagnetic, including dc, ac, rf, and microwave. A } \\
\text { separate Fee Schedule is issued annually, providing current prices for the services } \\
\text { offered, updates on points of contact, and information on measurement seminars. }\end{array}$ \\
\hline $\begin{array}{l}\text { NIST Special } \\
\text { Publication } 260\end{array}$ & Yes & $\begin{array}{l}\text { Available on-line at } \\
\text { http://ts.nist.gov/ts/htdocs/230/232/SP_PUBLICATIONS/PUBLICATIONS.HTM }\end{array}$ \\
\hline $\begin{array}{l}\text { NBS Special } \\
\text { Publication } 440\end{array}$ & Yes & $\begin{array}{l}\text { QC100 .U57 no.440, (1976) Color : universal language and dictionary of names / } \\
\text { Kenneth L. Kelly and Deane B. Judd, (Supersedes and combines The ISCC-NBS } \\
\text { method of designating colors and a dictionary of color names by K. L. Kelly and } \\
\text { D. B. Judd and A universal color language by K. L. Kelly.) }\end{array}$ \\
\hline $\begin{array}{l}\text { NBS Special } \\
\text { Publication } 442\end{array}$ & Yes & $\begin{array}{l}\text { TD353 .M351 (1983) " Supplement to Manual on water (fourth edition)" / } \\
\text { sponsored by ASTM Committee D-19 on Water ; C.E. Hamilton, editor }\end{array}$ \\
\hline $\begin{array}{l}\text { NIST Special } \\
\text { Publication } 500-172\end{array}$ & Yes & $\begin{array}{l}\text { QC100 .U57 no.500-172 (1989) "Computer security training guidelines" Mary } \\
\text { Anne Todd, Constance Guitian. }\end{array}$ \\
\hline
\end{tabular}




\begin{tabular}{|c|c|c|}
\hline NBS Circular 484 & Yes & $\begin{array}{l}\text { QC100 .U555 no.484 (1949) Gibson, K. S. "Spectrophotometry (200 to 1,000 } \\
\text { millimicrons)" }\end{array}$ \\
\hline \multicolumn{3}{|l|}{$\begin{array}{l}\text { Assorted } \\
\text { Publications }\end{array}$} \\
\hline $\begin{array}{l}\text { NBS/NIST IR 85- } \\
3273\end{array}$ & Yes & $\begin{array}{l}\text { NBS/NIST IR } 85-3273 \text { are annual supplements to NBS/NIST handbook } 135 \text { and } \\
\text { NBS/NISTspecial publication } 709\end{array}$ \\
\hline $\begin{array}{l}\text { NIST report on API } \\
\text { Publication } 1509\end{array}$ & No & $\begin{array}{l}\text { Unable to find NIST report to the FTC on test procedure based on API } \\
\text { Publication } 1509 \text { "Engine Oil Licensing and Certification System". }\end{array}$ \\
\hline NBSIR 84-7833 & Yes & $\begin{array}{l}\text { QC100 .U56 no. 84-2833 (1984) "Data requirements for the seismic review of } \\
\text { LNG facilities" William D. Kovacs }\end{array}$ \\
\hline DOC FF1-70 & No & $\begin{array}{l}\text { Originally available as ASTM D2859-76. Current version is "ASTM D2859-04 } \\
\text { Standard Test Method for Ignition Characteristics of Finished Textile Floor } \\
\text { Covering Materials" }\end{array}$ \\
\hline $\begin{array}{l}\text { NBS Report BSS- } \\
121\end{array}$ & Yes & $\begin{array}{l}\text { TA435 .U58 no.121, (1980) "Title Soil classification for construction practice in } \\
\text { shallow trenching" / Felix Y. Yokel and Richard L. Tucker, Lymon C. Reese ; } \\
\text { prepared for Occupational Safety and Health Administration, Department of } \\
\text { Labor and National Institute for Occupational Safety and Health, Department of } \\
\text { Health, Education, and Welfare. }\end{array}$ \\
\hline $\begin{array}{l}\text { NBS Report BSS- } \\
127\end{array}$ & Yes & $\begin{array}{l}\text { TA435 .U58 no. 127(1980) "Recommended technical provisions for construction } \\
\text { practice in shoring and sloping of trenches and excavations" / Felix Y. Yokel ; } \\
\text { prepared for the Occupational Safety and Health Administration, Department of } \\
\text { Labor, and National Institute for Occupational Safety and Health, Department of } \\
\text { Health, Education and Welfare. }\end{array}$ \\
\hline JCPDS-ICDD & Yes & $\begin{array}{l}1976 \text { version available in the NIST library. Recent versions are available through } \\
\text { ICDD at www.icdd.com (Commercial sales) }\end{array}$ \\
\hline $\begin{array}{l}\text { NBS Special } \\
\text { Publication } 506\end{array}$ & Yes & $\begin{array}{l}\text { QC100 .U57 no.506 (1978) "Asbestos: Definitions and Measurement Methods } \\
\text { (1977 : National Bureau of Standards) Title Proceedings of Workshop on } \\
\text { Asbestos : definitions and measurement methods / edited by C.C. Gravatt, Philip } \\
\text { D. LaFleur, and Kurt F. J. Heinrich ; sponsored by National Bureau of Standards } \\
\text { of the Dept. of Commerce and Occupational Safety and Health Administration of } \\
\text { the U.S. Dept. of Labor. }\end{array}$ \\
\hline $\begin{array}{l}\text { NBS Journal of } \\
\text { Research Vol. } 86 \\
(1981)\end{array}$ & Yes & $\begin{array}{l}\text { Specific citation is "DeVoe, H. et. al. "Generator Columns and High Pressure } \\
\text { Liquid Chromatography for Determining Aqueous Solubilities and Octanol-Water } \\
\text { Partition Coefficients of Hydrophobic Substances", Journal of Research of the } \\
\text { National Bureau of Standards, 86:361-366 (1981) }\end{array}$ \\
\hline NBSIR81-2406 & Yes & $\begin{array}{l}\text { QC100.U56 no.81-2406 (1981) "Octanol/water partition coefficients and aqueous } \\
\text { solubilities of organic compounds", Stanley P. Wasik ... [et al.]. }\end{array}$ \\
\hline NBS Report 4792 & No & $\begin{array}{l}\text { No reference found in NIST archives to } 1956 \text { NBS Report } 4792 \text { "Development of } \\
\text { a Laboratory Test for Evaluation of the Effectiveness of Smoke Signals" }\end{array}$ \\
\hline $\begin{array}{l}\text { NBS Simplified } \\
\text { Practice } \\
\text { Recommendation } \\
\text { R178-41 }\end{array}$ & Yes & $\begin{array}{l}\text { Simplied Practice Recommendations were the predecessors to the Product } \\
\text { Standards which in turn were transformed into Voluntary Product Standards. }\end{array}$ \\
\hline $\begin{array}{l}\text { NBS Building } \\
\text { Materials and } \\
\text { Structures Report } \\
150\end{array}$ & Maybe & $\begin{array}{l}\text { Check to see if Building Materials and Structures Report series is the same as the } \\
\text { Building Science Series }\end{array}$ \\
\hline $\begin{array}{l}\text { NBS Technical } \\
\text { Note } 101\end{array}$ & Yes & \\
\hline
\end{tabular}




\begin{tabular}{|c|c|c|}
\hline NBSIR 83-2694 & Yes & $\begin{array}{l}\text { QC100 .U56 no.83-2694 (1983) "Some criteria for colors and signs in } \\
\text { workplaces", Robert A. Glass ... [et al.] for OSHA }\end{array}$ \\
\hline NBSTN 1180 & Yes & $\begin{array}{l}\text { QC100 .U5753 no.1180 (1983) "Size of letters required for visibility as a function } \\
\text { of viewing distance and observer visual acuity", Gerald L. Howett; sponsored by } \\
\text { OSHA }\end{array}$ \\
\hline NBSIR 80-2088 & No & $\begin{array}{l}\text { T55.3.S5 L4 } 1980 \text { Local LC call number QC100 .56 no.80-2088 (1980) "The } \\
\text { assessment of safety symbol understandability by different testing methods" Neil } \\
\text { D. Lerner, Belinda L. Collins. - library copy that should not be checked out is in } \\
\text { circulation and hence stated as not available. }\end{array}$ \\
\hline NBSIR 80-2003 & Yes & $\begin{array}{l}\text { QC100 .U56 no.80-2003 (1980) "Workplace safety symbols : current status and } \\
\text { research needs", Neil D. Lerner, Belinda L. Collins. }\end{array}$ \\
\hline NBSIR $82-2485$ & Yes & $\begin{array}{l}\text { QC100 .U56 no.82-2485 (1982) "Symbols for industrial safety", Belinda L. } \\
\text { Collins, Neil D. Lerner, Brian C. Pierman. }\end{array}$ \\
\hline NBSTN 964 & Yes & $\begin{array}{l}\text { QC100 .U5753 no.964 (1978) "Fire alarm and communication systems", Richard } \\
\text { W. Bukowski, Richard L. P. Custer, Richard G. Bright. }\end{array}$ \\
\hline NBS VPS $36-70$ & No & $\begin{array}{l}\text { "Body Measurements for Sizing Boys Apparel (formerly CS 155-50) - No longer } \\
\text { available as NBS/NIST/DoC standards. }\end{array}$ \\
\hline NBS VPS 54-72 & No & $\begin{array}{l}\text { "Body Measurements for Sizing Girls Apparel (sizes 7-14) (formerly CS 153-48)- } \\
\text { No longer available as NBS/NIST/DoC standards. }\end{array}$ \\
\hline NIST (V)PS 1-83 & Yes & $\begin{array}{l}\text { "Product Standard for Construction and Industrial Plywood with Typical APA } \\
\text { Trademarks". Revised and currently available as PS 1-95 "Construction and } \\
\text { Industrial Plywood" at: http://ts.nist.gov/ts/htdocs/210/sccg/ps1-95.pdf }\end{array}$ \\
\hline NIST PS 2-92 & Yes & $\begin{array}{l}\text { "Performance Standard for Wood-Based Structural Use Panels", available online } \\
\text { at: http://ts.nist.gov/ts/htdocs/210/sccg/ps2-92.pdf }\end{array}$ \\
\hline NIST VPS 20-94 & Yes & $\begin{array}{l}\text { American Softwood Lumber Standard, now revised and available as PS20-99. } \\
\text { Available online at: http://ts.nist.gov/ts/htdocs/210/sccg/ps20-99.pdf }\end{array}$ \\
\hline NIST CS 138-55 & No & "Insect Wire Screening"- No longer available as NBS/NIST/DoC standards. \\
\hline NBS CS 242-62 & No & $\begin{array}{l}\text { "1-3/4" Steel Doors and Frames"- No longer available as NBS/NIST/DoC } \\
\text { standards. }\end{array}$ \\
\hline NBS CS 202-56 & No & $\begin{array}{l}\text { "Industrial Lifts and Hinged Loading Ramps"- No longer available as } \\
\text { NBS/NIST/DoC standards. }\end{array}$ \\
\hline NBS FIPS Pub. 1-1 & No & $\begin{array}{l}\text { No reference to NBS FIPS Publication 1-1. Closest match appears to be FIPS 1-2 } \\
\text { "Code for Information Interchange, Its Representations, Subsets, and Extensions } \\
\text { (ANSI X3.4- 1986/R1992, X3.32- 1990, X3.41- 1990)", which was withdrawn in } \\
1997 .\end{array}$ \\
\hline $\begin{array}{l}\text { FIPS publication } \\
\text { with state's } \\
\text { identifying code }\end{array}$ & Yes & $\begin{array}{l}\text { CFR citations do not identify particular FIPS publication with this information, } \\
\text { which is FIPS Pub 55-DC3. Available online at } \\
\text { http://www.itl.nist.gov/fipspubs/fip55-3.htm }\end{array}$ \\
\hline $\begin{array}{l}\text { Computer security } \\
\text { guidelines for } \\
\text { implementing the } \\
\text { Privacy Act of } 1974\end{array}$ & $\begin{array}{l}\text { Yes, but } \\
\text { withdrawn }\end{array}$ & $\begin{array}{l}\text { CFR citations do not identify particular FIPS publication with this information, } \\
\text { which is FIPS Pub 41, available at http://www.itl.nist.gov/fipspubs/fips41.pdf. } \\
\text { However, this FIPS publication was withdrawn in } 1998\end{array}$ \\
\hline $\begin{array}{l}\text { Computer security } \\
\text { guidelines for } \\
\text { safeguards for data }\end{array}$ & Yes & $\begin{array}{l}\text { CFR citations do not identify particular FIPS publication with this information, } \\
\text { which is FIPS Pub 31, available at } \\
\text { http://csrc.nist.gov/publications/fips/fips31/fips31.pdf }\end{array}$ \\
\hline
\end{tabular}

